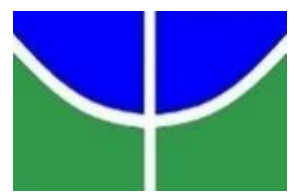

UNIVERSIDADE DE BRASÍLIA

INSTITUTO DE PSICOLOGIA

Programa de Pós-Graduação em Processos de Desenvolvimento Humano e Saúde

A PESQUISA DE INTERVENÇÃO NO DESENVOLVIMENTO DE COMPETÊNCIAS MATEMÁTICAS: UM ESTUDO COM ALUNOS DO $5^{\circ}$ ANO DO ENSINO FUNDAMENTAL

Maria Juliana de Freitas Carvalho Lopes

Brasília, dezembro de 2015 
Ficha catalográfica elaborada automaticamente, com os dados fornecidos pelo(a) autor(a)

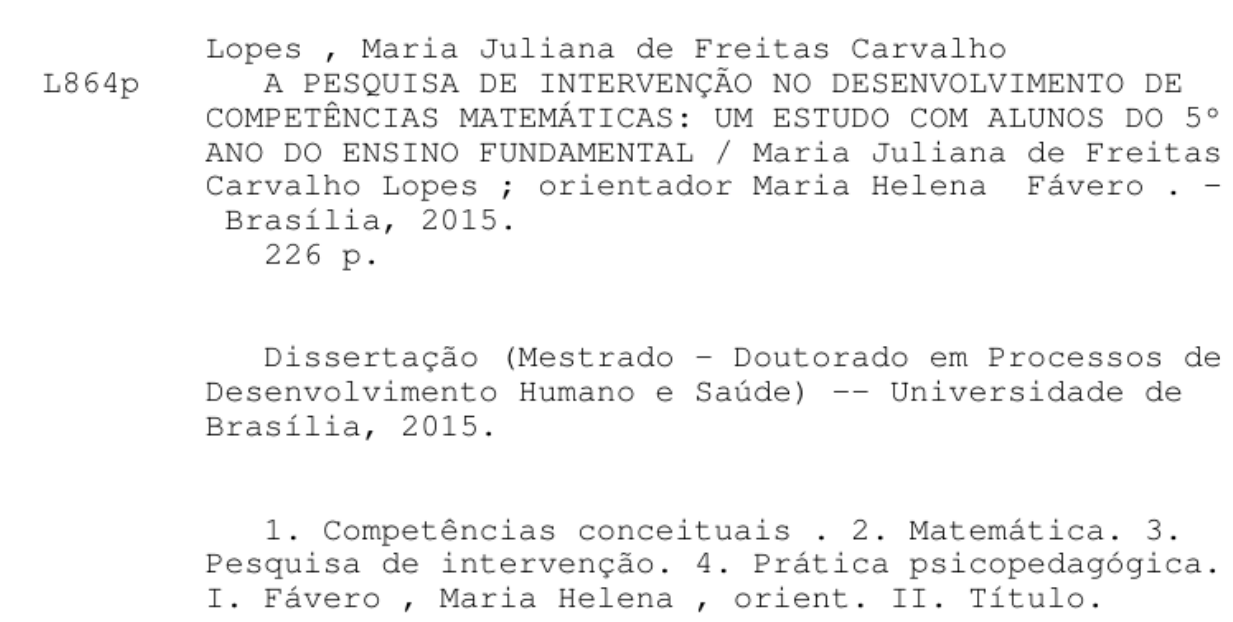




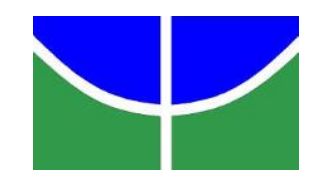

UNIVERSIDADE DE BRASÍLIA

INSTITUTO DE PSICOLOGIA

Programa de Pós-Graduação em Processos de Desenvolvimento Humano e Saúde

\title{
A PESQUISA DE INTERVENÇÃO NO DESENVOLVIMENTO DE COMPETÊNCIAS MATEMÁTICAS: UM ESTUDO COM ALUNOS DO $5^{\circ}$ ANO DO ENSINO FUNDAMENTAL
}

Maria Juliana de Freitas Carvalho Lopes

\begin{abstract}
Dissertação apresentada ao Instituto de Psicologia da Universidade de Brasília, como requisito parcial à obtenção do título de Mestre em Processos de Desenvolvimento Humano e Saúde, na área de concentração Desenvolvimento Humano e Educação.
\end{abstract}

Orientadora: Profa. Dra. Maria Helena Fávero 
UNIVERSIDADE DE BRASÍLIA

INSTITUTO DE PSICOLOGIA

DISSERTAÇÃO DE MESTRADO APROVADA PELA SEGUINTE BANCA EXAMINADORA:

Profa. Dra. Maria Helena Fávero - Presidente

Instituto de Psicologia - Universidade de Brasília

Profa. Dra. Regina Pina das Neves (MAT/IE/UNB) - Membro

Departamento de Matemática - Universidade de Brasília

Profa. Dra. Diva de Albuquerque Maciel (PED/UNB) - Membro

Instituto de Psicologia - Universidade de Brasília

Profa. Dra. Regina Lúcia Sucupira Pedroza (PED/UNB) - Membro Suplente Instituto de Psicologia - Universidade de Brasília

Brasília, dezembro de 2015 
Dedico este trabalho, em primeiro lugar, Àquele que está acima de tudo e de todos $e$ que foi o meu refúgio ao longo deste mestrado!

(Deus).

Dedico também à pessoa que me encorajou a fazer este mestrado e que me faz sentir, todos os dias, a pessoa mais amada do mundo. (Meu esposo Jailton).

E, por fim, às três crianças maravilhosas que preenchem meus dias com alegria e amor. (Miguel, Júlia e Heloísa). 


\section{Agradecimentos}

Ao longo destes dois anos de mestrado, recebi o apoio e a colaboração de pessoas que me foram muito importantes. E a elas expresso a minha gratidão neste momento.

Àquela que observou de perto o meu desenvolvimento, minha orientadora, professora Doutora Maria Helena Fávero. Obrigada por sua parceria, seu apoio, sua organização, por todo o conhecimento compartilhado neste mestrado. Aprendi muito com você!

Às professoras Regina Pina, Diva Maciel e Regina Pedroza por terem aceitado participar da banca avaliadora desta dissertação.

À Secretaria de Educação do Distrito Federal, por ter me concedido o tempo necessário para que eu pudesse me dedicar aos estudos.

À direção e profissionais da Escola Classe 50 de Taguatinga, por terem aberto as portas da sua instituição para a pesquisa. Agradeço de forma especial a Silvânia, Daidra, Célia e Marly.

Aos alunos, Af e Am, e aos seus responsáveis, pela disponibilidade em participar da pesquisa.

Agradeço também a Gislene Maria Barral, que, com muito profissionalismo, se dedicou à revisão do meu texto. Você foi uma parceira!

À professora Doutora Denise Vieira, minha orientadora no Curso de Psicopedagogia, por ter me incentivado a participar da seleção de mestrado.

Ao meu esposo Jailton Lopes, que me apoiou em todos os momentos, desde a seleção do mestrado até a finalização desta dissertação.

Agradeço ainda, de forma muito carinhosa, a meus pais e familiares, por terem me dado o suporte necessário para que eu pudesse, com tranquilidade, estudar. 


\section{Sumário}

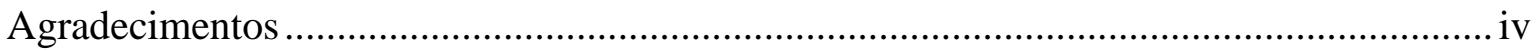

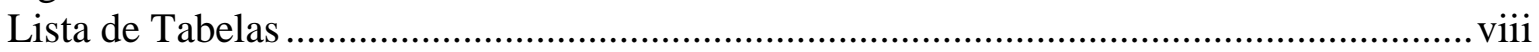

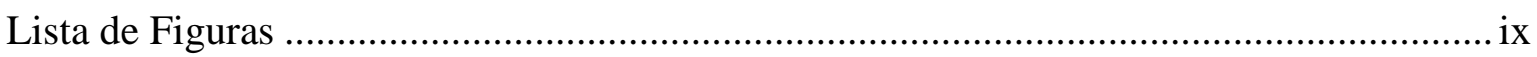

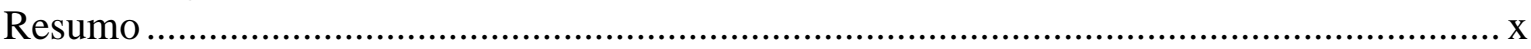

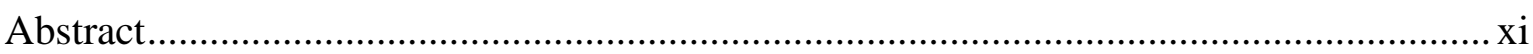

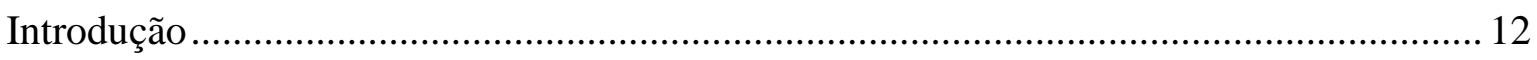

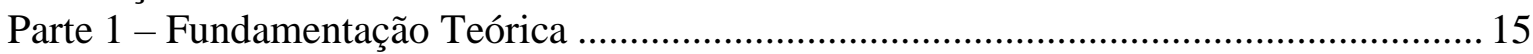

1.1 A Pesquisa Sobre Ensino e Aprendizagem da Matemática na Escola: REVISÃO DE ARTIGOS EM PERIÓDICOS....................................................................... 16

1.1.1 A primeira categoria de artigos: afetividade, atitude e motivação em relação à Matemática 18

1.1.2 A segunda categoria de artigos: o ensino da Matemática e o desenvolvimento atípico

1.1.3 A terceira categoria de artigos: processos de aquisição de competências matemáticas.

1.1.4 A quarta categoria de artigos: Matemática e formação de professores e outros

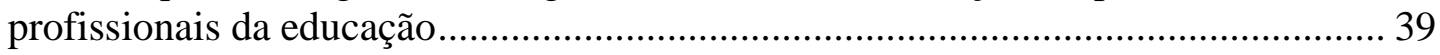

1.1.5 Discussão geral das categorias e conclusões.................................................. 44

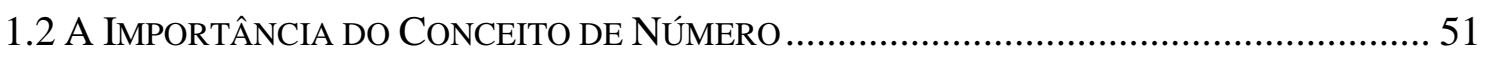

1.3 A COMPREENSÃo DO SiSTEMA DE NuMERAÇÃO DECIMAL (SND)............................. 55

1.4 A Interação Social, a Resolução de Problemas E a RepresentaÇão e o REGISTRO, COMO ELEMENTOS NA FORMAÇÃO DE CONCEITOS ......................................... 60

Parte 2 - A Pesquisa de Intervenção: o desenvolvimento de competências numéricas ...... 67

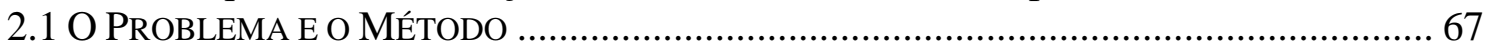

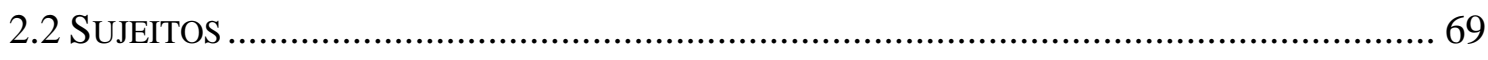

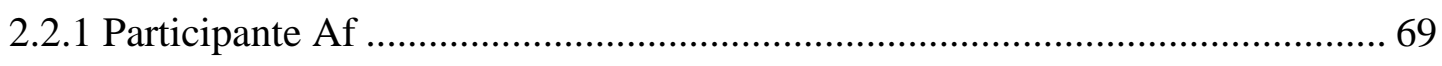

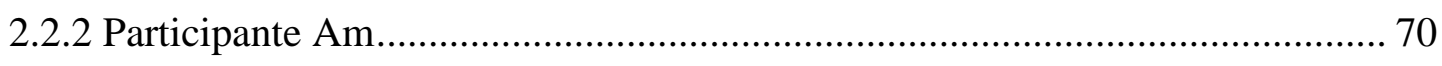

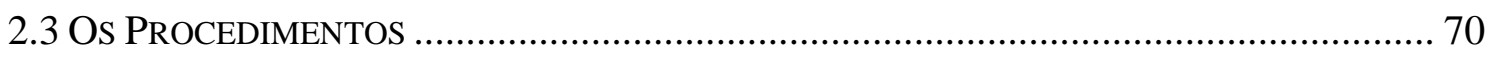

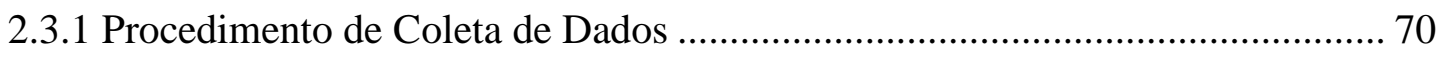

2.3.2 Procedimento de Análise dos Dados........................................................... 73

2.4 Os ReSUltados OBtidos EM CADA FASE .......................................................... 74

2.4.1 Primeira fase: as entrevistas, a Prova ECPN (Groupe Cimete, 1995), as análises

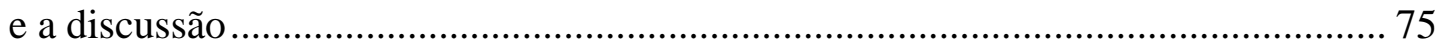

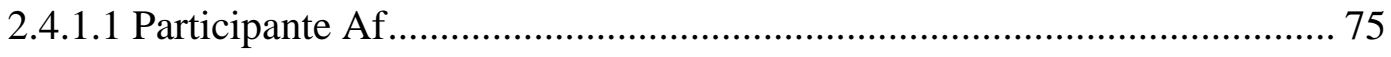

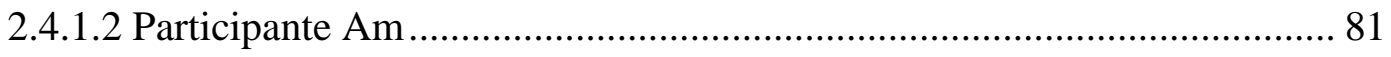

2.4.1.3 Discussão dos dados obtidos nas entrevistas.......................................... 85

2.4.1.4 Dados obtidos na prova ECPN (Groupe Cimete, 1995).......................... 89

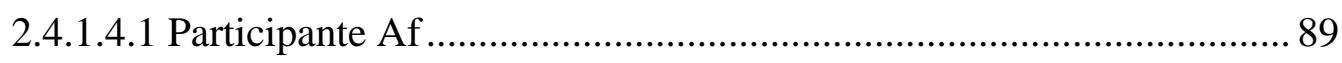


2.4.1.4.2 Participante Am .94

2.4.1.5 Discussão dos dados obtidos na segunda etapa da primeira fase da coleta de dados: a avaliação das competências e dificuldades matemáticas 99

2.4.1.6 Discussão geral da primeira fase da coleta de dados: o fundamento para a intervenção psicopedagógica. 101

2.4.2 Segunda fase: as sessões de intervenção psicopedagógica e as entrevistas realizadas após as sessões 103

2.4.2.1 Primeira sessão de intervenção psicopedagógica 104

2.4.2.1.1 Desenvolvimento, resultados e discussão da primeira sessão . 104

2.4.2.2 Segunda sessão de intervenção psicopedagógica 106

2.4.2.2.1 Desenvolvimento, resultados e discussão da $2^{\mathrm{a}}$ sessão. 106

2.4.2.3 Terceira sessão de intervenção psicopedagógica 116

2.4.2.3.1 Desenvolvimento, resultados e discussão da terceira sessão. 116

2.4.2.4 Quarta sessão de intervenção 120

2.4.2.4.1 Desenvolvimento, resultados e discussão da quarta sessão. 121

2.4.2.5 Quinta sessão de intervenção 126

2.4.2.5.1 Desenvolvimento, resultados e discussão da quinta sessão. 126

2.4.2.6 Sexta sessão de intervenção 130

2.4.2.6.1 Desenvolvimento, resultados e discussão da sexta sessão 130

2.4.2.7 Sétima sessão de intervenção 135

2.4.2.7.1 Desenvolvimento, resultados e discussão da sétima sessão 135

2.4.2.8 Oitava sessão de intervenção 139

2.4.2.8.1 Desenvolvimento, resultados e discussão da oitava sessão 140

2.4.2.9 Nona sessão de intervenção 144

2.4.2.9.1 Desenvolvimento, resultados e discussão da nona sessão 144

2.4.2.10 Décima sessão de intervenção psicopedagógica ....

2.4.2.10.1 Desenvolvimento, resultados e discussão da décima sessão 147

2.4.2.11 Décima primeira sessão de intervenção psicopedagógica. 153

2.4.2.11.1 Desenvolvimento, resultados e discussão da décima primeira sessão. 154

2.4.2.12 Décima segunda sessão de intervenção psicopedagógica. 158

2.4.2.12.1 Desenvolvimento, resultados e discussão da décima segunda sessão. 158

2.4.2.13 Décima terceira sessão de intervenção psicopedagógica ..... 162

2.4.2.13.1 Desenvolvimento, resultados e discussão da décima terceira sessão 162

2.4.2.14 Décima quarta sessão de intervenção psicopedagógica ..... 167 
2.4.2.14.1 Desenvolvimento, resultados e discussão da décima quarta sessão 167

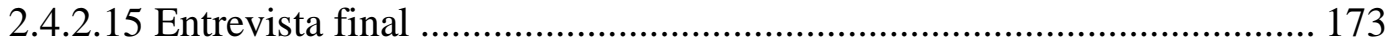

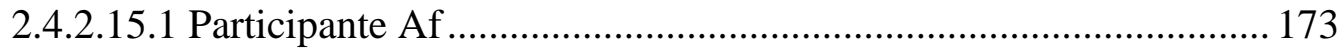

2.4.2.15.2 Participante Am .................................................................... 175

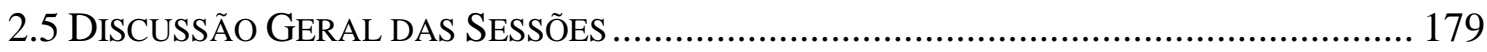

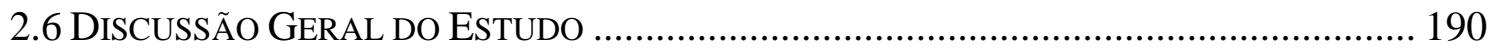

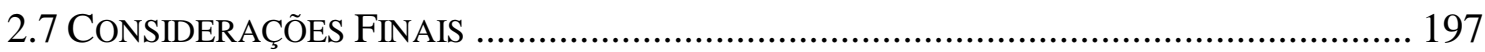

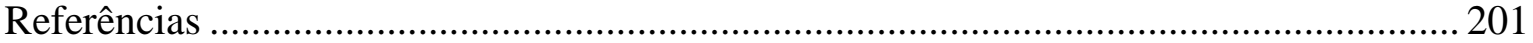

Anexo 1 - Aprovação do Projeto de Pesquisa pelo CEP (Conselho de Ética em Pesquisa)

213

Anexo 2 - Autorização da Secretaria de Educação do Distrito Federal para realização de

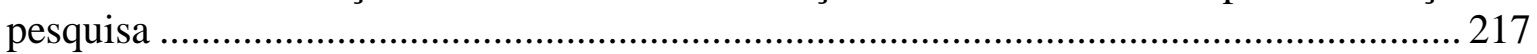

Anexo 3 - Termo de Consentimento Livre Esclarecido (TCLE) ...................................... 219

Anexo 4 - Termo de Utilização de Voz e de Imagem....................................................... 221

Anexo 5 - Termo de Assentimento ............................................................................. 223

Anexo 6 - Termo de responsabilidade pelo uso de informações de documentos para fins de

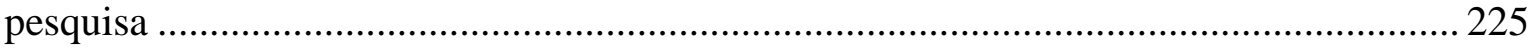




\section{Lista de Tabelas}

Tabela 1 - Artigos Sobre Afetividade, Atitude e Motivação em Relação à Matemática.... 18

Tabela 2 - Artigos da categoria Matemática e necessidades educacionais especiais ......... 24

Tabela 3 - Artigos sobre processos de aquisição de competências matemáticas................. 30

Tabela 4 - Artigos sobre formação de professores e outros profissionais da educação...... 39

Tabela 5 - Símbolos propostos por Tian, Jimarkson e Singhasiri (2011) para a ampla transcrição 72

Tabela 6 - Desempenho da participante Af na prova ECPN - (Groupe Cimete, 1995).... 89

Tabela 7 - Desempenho do participante Am na prova ECPN - Cimete (1995). 94 


\section{Lista de Figuras}

Figura 1. Exemplo de resolução dos valores relativo e absoluto do algarismo 1 no numeral 158.

Figura 2. Notação produzida por Af para representar o numeral 1203 e suas respectivas ordens no Sistema de Numeração Decimal. 79

Figura 3. Resolução da questão envolvendo limões. 84

Figura 4. Cálculos de AF para a situação-problema quantas receitas fariam para conseguir produzir 100 docinhos.

Figura 5. Cálculos de Am para a situação-problema quantas receitas fariam para conseguir produzir 100 docinhos.

Figura 6. Estratégia utilizada por Am para o cálculo de 7+7+7+7

Figura 7. Registros dos procedimentos de Af.

Figura 8. Representação de Am para as forminhas de brigadeiro, antes e depois de abertas.

Figura 9. Registro de Af

Figura 10. Registro de Am

Figura 11. Registro dos grupinhos de Am.

Figura 12. Moedas e notas distribuídas nas 20 forminhas de brigadeiro.

Figura 13. Algoritmo de Af

Figura 14. Representação da participante Af, do valor R \$11,36

Figura 15. Tabela utilizada para o registro dos valores.

Figura 16. Tabela com os registros dos valores das moedas.

Figura 17. Registros de Af, para a resolução da situação-problema 


\section{Resumo}

Resultados de pesquisas nacionais e internacionais indicam que o ensino da Matemática tem se pautado prioritariamente pela utilização de regras e algoritmos formalizados. Observa-se que os alunos apresentam uma incompreensão da lógica do Sistema de Numeração Decimal, embora, como alternativa aos algoritmos formalizados, eles produzam suas próprias notações para a resolução de cálculos e situações-problemas. Contudo, esses procedimentos próprios dos alunos, que representam o raciocínio, na situação em questão, são, na maioria das vezes, desqualificados e rejeitados pelos docentes. Reforçando essa conjuntura, as publicações nos periódicos de Psicologia e Educação apontam um baixo desempenho dos alunos. Outros estudos apontam que são necessárias mudanças nas práticas de ensino e sugerem que os alunos sejam encorajados no uso de procedimentos pessoais de cálculos no processo de construção da compreensão dos algoritmos matemáticos formalizados. As publicações, analisadas neste estudo, evidenciam uma escassez significativa de pesquisas metodológicas de intervenção com alunos que apresentam baixo desempenho escolar. Considerando esses aspectos, esta pesquisa de mestrado teve como objetivo a realização de uma pesquisa metodológica de intervenção psicológica com alunos do $5^{\circ}$ ano do Ensino Fundamental, de uma escola pública do Distrito Federal, que eram considerados, por suas professoras, com baixo desempenho escolar em Matemática, visando o desenvolvimento de competências conceituais nessa mesma disciplina. Participaram dois alunos do quinto, um do sexo feminino e outro do sexo masculino, ambos com 11 anos de idade. A perspectiva metodológica adotada foi a desenvolvida por Fávero (2009a, 2009b, 2011, 2012). A coleta de dados foi dividida em duas fases. Na primeira, foi realizada a avaliação psicopedagógica das competências e dificuldades em Matemática. Evidenciaram-se dificuldades dos sujeitos quanto à lógica do Sistema de Numeração Decimal e a sua notação; além de competências em relacionar as palavras número às suas quantidades, realização de cálculos mentais de pequenas quantidades, competência para adicionar ou subtrair a partir de uma quantidade já existente, realização de contagem termo a termo, cardinalização e investigação de estados iniciais ou transformações de cálculos aritméticos envolvendo pequenas quantidades. $\mathrm{Na}$ segunda fase da coleta de dados, desenvolveram-se sessões de intervenção psicopedagógica interativas, focadas no desenvolvimento de competências relacionadas ao Sistema Numérico Decimal e sua notação. Os dados obtidos evidenciaram que: 1) os sujeitos passaram da negação do uso de materiais concretos, para a sua utilização como suporte para as resoluções de situações-problemas; 2) substituíram a ação de indicar uma resposta a um problema, de forma imediata, pela investigação de procedimentos pertinentes à sua resolução; 3) construíram a compreensão do valor posicional, do uso da vírgula nos números decimais e a função e o uso do numeral zero; 4) desenvolveram as competências relacionadas aos componentes do significado de número. Esses dados evidenciam a relação entre dificuldades e competências e demonstram que, por meio da intervenção psicopedagógica com foco na mediação semiótica, podem se desenvolver processos de tomada de consciência relativos aos conceitos matemáticos.

Palavras-chave: Competências conceituais, Matemática, Pesquisa de intervenção, Prática psicopedagógica. 


\begin{abstract}
Results of national and international research indicate that mathematics teaching has been guided primarily by the use of formalized rules and algorithms. It is observed that students present a logical incomprehension of Decimal Numbering System, though, as an alternative to formal algorithms, they produce their own ratings for solving calculations and problem situations. However, these very procedures of the students, representing the reasoning in the situation in question are, in most cases, disqualified and rejected by teachers. Reinforcing this juncture, the publications of journals in Psychology and Education indicate a low student performance. Other studies show that changes are needed in teaching practices and suggest that students be encouraged in the use of personal calculation procedures in the construction process of understanding of formal mathematical algorithms. Publications, analyzed in this study show a significant shortage of intervention methodological research with students with poor academic performance. Considering these aspects, this master's research aimed to carry out a methodological research of psychological intervention with students of the 5th year of elementary school, a public school in the Distrito Federal, which were considered by their teachers, with poor school performance mathematics, to develop conceptual skills that same discipline. Two students attended the fifth, one female and one male, both 11 years old. The methodological approach adopted was developed by Fávero (2009a, 2009b, 2011, 2012). Data collection was divided into two phases. At first it was carried out the psycho-pedagogical assessment of skills and difficulties in mathematics, focusing on the logic of the decimal numerical system and its notation. They showed up difficulties of the subjects on the logic of the decimal number system and its notation; as well as skills in relating the words number to their amounts, performing mental calculations of small amounts, the power to add or subtract from an existing amount, achievement term count term, cardinalization and investigation of initial states or transformations calculations arithmetic involving small amounts. In the second phase of the research, they have developed interactive pedagogical intervention sessions, focused on the development of skills related to the decimal numerical system and its notation. The data obtained showed that: 1) the subjects were denial of the use of specific materials to their use as a support for the resolutions situations problems; 2) replaced the action to indicate an answer to a problem, immediately, the research relevant procedures for resolution; 3) built an understanding of place value, the decimal point in the use of decimal numbers and function and use of the numeral zero; 4) developed skills related to components of the number of meaning. These data show the relationship between difficulties and skills and demonstrate that, through the pedagogical intervention focusing on semiotic mediation, may develop consciousness-making processes related to mathematical concepts.
\end{abstract}

Keywords: Conceptual skills, Mathematics, Intervention research, Psycho-pedagogical practice. 


\section{Introdução}

A passagem das séries iniciais para as finais do Ensino Fundamental, particularmente do $5^{\circ}$ para o $6^{\circ}$ ano, tem gerado uma séria condição de evasão e repetência entre os alunos das escolas públicas, que podemos considerar como uma situação de exclusão escolar. No artigo de Fávero e Pina (2009) esse momento da escolarização é apontado como um gargalo, no qual, entre o quinto e o sétimo ano do Ensino Fundamental, os alunos apresentam dificuldades na Matemática, principalmente em tarefas relativas aos números racionais e também à divisão (ver os dados recentes da Avaliação Nacional da Alfabetização Brasil, 2014).

Fávero e Carneiro Soares (2002), Pina Neves (2008), Fávero e Pina Neves (2009), Forero e Fávero (2010) e Fávero (2011) demonstram que os alunos, nessa fase de escolaridade, evitam o uso de algoritmos formalizados, principalmente o da multiplicação e o da divisão, empregando alternativas pessoais para a resolução de situações-problemas. Esses procedimentos adotados pelos alunos, embora sejam, muitas vezes, negligenciados pela escola, são de suma importância para subsidiar futuras aquisições matemáticas (Moro, 2004; Muniz, 2009).

Em sua tese de doutorado, Pina Neves (2008) aponta que a queixa dos professores de Matemática se relaciona às dificuldades dos alunos, sobretudo quanto à utilização do algoritmo da multiplicação e da divisão, bem como na resolução de situações-problemas e números racionais. Em consonância com esses dados, Corona (2010) afirma que o estudo da Matemática deve proporcionar ao aluno a competência para utilizar formas variadas de cálculo, a fim de encontrar o resultado de um mesmo problema, sem se prender a um padrão, como ocorre quando o ensino enfatiza a resolução de algoritmos.

As dificuldades dos alunos em Matemática possuem várias propostas de explicação. Mendonça, Pinto, Carzola e Ribeiro (2007), por exemplo, defendem que tais dificuldades 
não decorrem de problemas no desenvolvimento cognitivo dos alunos, mas de falhas no processo de escolarização. Com um argumento semelhante, Fuson (2009) afirma que equívocos na adoção de teorias e práticas pedagógicas podem dificultar a compreensão dos alunos, impedindo-os de alcançarem níveis mais avançados de seu desenvolvimento cognitivo.

Fávero $(2000,2009,2011)$ vem defendendo, sistematicamente, que a questão central da compreensão da Matemática escolar está na compreensão do Sistema Numérico Decimal. A autora já comprovou isso por meio de vários estudos (Fávero \& Pimenta, 2006; Fávero \& Soares, 2002; Fávero \& Vieira, 2004). Outro autor que defende essa mesma posição é Muniz (2014), o qual afirma que a construção do conceito de número e o entendimento da estrutura do Sistema de Numeração Decimal são basilares para que haja a compreensão tanto da leitura quanto da escrita de um número. Para ele, isso possibilita o desenvolvimento de procedimentos operatórios, uma vez que o entendimento das estruturas decimal e posicional favorece o desenvolvimento de habilidades, referentes aos processos do sistema de medidas e também àqueles relacionados ao tratamento da informação e aos processos estatísticos.

Considerando tais questões, a pesquisa, aqui descrita, teve dois focos: 1) O desenvolvimento de atividades psicopedagógicas que propiciassem o desenvolvimento de competências numéricas e 2) evidenciar a natureza das dificuldades matemáticas e a relação entre competência e dificuldades. Para contemplar esses dois focos, adotamos a proposta metodológica de Fávero (2009a, 2009b), que articula quatro aspectos teóricos e conceituais: a interação entre as regulações cognitivas e as regulações sociais; a mediação semiótica; o efeito do sistema de signos no desenvolvimento psicológico e na cognição; e a tomada de consciência. Segundo essa autora, isso implica considerar três aspectos psicológicos. O primeiro deles se relaciona à formação de conceitos e seu sistema lógico 
de representação. O segundo, diz respeito à tomada de consciência e à interação social em que esses conceitos são formados. E o terceiro é relativo à interação social, que caracteriza a situação didática na qual aqueles conceitos são construídos. Nesse contexto, o conhecimento é resultado de um processo psicológico (Fávero, 2009b).

Sendo assim, organizamos esta dissertação em duas partes. Na primeira, expomos a fundamentação teórica, apresentada em quatro itens: 1) A pesquisa sobre ensino e aprendizagem da Matemática na escola: revisão de artigos; 2) A importância do desenvolvimento do conceito de número; 3) A compreensão do Sistema de Numeração Decimal (SND); 4) A Interação Social, a Resolução de Problemas e a Representação e o Registro: processos para a formação de conceitos. Na segunda parte, explicitamos o método adotado em nossa pesquisa de intervenção, descrevendo os participantes, o procedimento de coleta e de análise dos dados. Apresentamos ainda, os resultados da pesquisa e a análise de cada sessão de avaliação psicopedagógica e de cada sessão de intervenção psicopedagógica desenvolvida, além de apresentarmos também a discussão geral relativa a essas sessões de intervenção.

Apresentamos, ao final, uma discussão geral do estudo, na qual retomamos os dados principais de toda a nossa produção, seguida das considerações finais, em que evidenciamos uma relação entre o nosso objetivo geral e os dados obtidos. Para tanto, buscamos explorar a abertura que tais dados sugerem em termos de novas pesquisas e em termos da prática escolar, sobretudo no que se refere à relação entre inclusão e exclusão. 


\section{Parte 1 - Fundamentação Teórica}

Como já afirmado na introdução, nossa fundamentação teórica abrange quatro itens: 1) A pesquisa sobre ensino e aprendizagem da Matemática na escola: revisão de artigos; 2) A importância do desenvolvimento do conceito de número; 3) A compreensão do Sistema de Numeração Decimal (SND); 4) A Interação Social, a Resolução de Problemas e a Representação e o Registro, como elementos para a formação de conceitos. Assim, no primeiro item do nosso trabalho, apresentamos os resultados de uma pesquisa bibliográfica que foi realizada em periódicos de Psicologia e de Educação focada no ensino e aprendizagem da Matemática.

No segundo item de nossa fundamentação teórica, discutimos a construção do conceito de número, retomando algumas das principais contribuições de autores clássicos que se debruçaram sobre o tema, como Piaget e Szeminska (1975) e Gelman e Gallistel (1978), assim como aquelas contribuições de autores contemporâneos, como Fávero (2004), Muniz (2009), entre outros. Está fundamentado também em Vergnaud (1986, 1990, 2007, 2009a), além de alicerçar-se em outros trabalhos produzidos na literatura internacional, como, por exemplo, Corona (2010) e Yang, Li e Li (2008), que abordam os principais elementos da construção do sentido de número.

No terceiro item da fundamentação teórica, discutimos a compreensão do Sistema de Numeração Decimal (SND), apresentando características relativas a esse sistema. Apontamos, ainda, algumas dificuldades comuns às crianças e aos adultos nessa situação de aprendizagem escolar. Por fim, no quarto item desenvolvido nesta Fundamentação Teórica: a Interação Social, a Resolução de Problemas e a Representação e o Registro, retomamos alguns pontos da proposta teórico-metodológica de Fávero (2007, 2009, 2011, 2012), subsidiada pelas ideias de autores como Piaget (1977), Vygotsky (2001) e Duval (2012, 2013). 


\subsection{A Pesquisa Sobre Ensino e Aprendizagem da Matemática na Escola: Revisão de Artigos em Periódicos}

Com o objetivo de obter dados sobre a produção científica, relativa ao ensino e à aprendizagem da Matemática na escola, empreendemos uma revisão de artigos publicados no período compreendido entre o ano de 2004 até o primeiro semestre de 2014. Em um primeiro momento, pesquisamos no banco de dados SCIELO - Scientific Eletronic Library -, utilizando como palavras-chave os termos: Ensino da Matemática; Psicologia da Educação Matemática.

A partir dessa primeira busca, obtivemos publicações nos periódicos: Psicologia em Estudo (Maringá), Estudos de Psicologia (Natal), Educar em Revista (Curitiba), Revista Brasileira de Educação Especial (Marília), Revista Brasileira de Educação (Rio de Janeiro), Psicologia (São Paulo), Ciência e Educação (Bauru), Cadernos de Pesquisa (São

Paulo), Caderno Cedes (Campinas), Bolema (Rio Claro), Psicologia Escolar e Educacional (Maringá), Estudos de Psicologia (Campinas), Zetetiké (Campinas) Análise Psicológica (Lisboa), Relime (México) e Paidéia (Belo Horizonte).

Em um segundo momento, acessamos os sites de revistas com Qualis A1 e B1 em Psicologia, na avaliação da CAPES, e realizamos a análise de todos os volumes publicados no período acima mencionado. Os periódicos foram: Psicologia: Teoria e Pesquisa (Brasília), Psicologia Reflexão e Crítica (Porto Alegre), Avaliação Psicológica (Itatiba), Avaliação (Campinas), Brazilian Cultural Studies (Itaquera), Cadernos Pagu (Campinas), Educação em Revista (Belo Horizonte), Educação e Pesquisa (São Paulo), Educação e Realidade (Porto Alegre), Estudos e Pesquisas em Psicologia (Rio de Janeiro), Fractal: Revista de Psicologia (Rio de Janeiro), Psicologia Educação e Cultura (Vila Nova de Gaia, Portugal), Psicologia em Revista (Belo Horizonte), Psicologia Escolar $e$ Educacional (Maringá), Análise Psicológica (Portugal), Revista Brasileira de Crescimento 
e Desenvolvimento Humano (São Paulo), Revista Brasileira de Educação Especial (Marília), Revista Brasileira de Educação (Rio de Janeiro).

No total desta pesquisa descrita, obtivemos 82 artigos. Desses, conservamos 45 , referentes explicitamente ao ensino e à aprendizagem de Matemática. Descartamos aqueles que não atendiam ao nosso critério e procedemos à leitura de cada um dos artigos selecionados, focando os seguintes itens: objetivo, tese, metodologia e conclusão. Essa análise nos permitiu organizá-los em 4 categorias: 1- Afetividade, atitude e motivação em relação à Matemática; 2- O ensino da Matemática e desenvolvimento atípico; 3- Processos de aquisição de competências matemáticas; 4- A formação de professores de Matemática e outros profissionais da educação.

Em um procedimento de análise e síntese, tal como proposto por Fávero e Sousa (2001) e retomado por Fávero e Pina Neves (2012), e que é compatível com análises bibliográficas internacionais como as de Waitoller e Artiles (2013) e Cara (2013), realizamos a categorização dos artigos e os apresentamos em tabelas. Na primeira coluna, fornecemos um contador referente aos artigos; na segunda apresentamos a referência completa de cada artigo; na terceira descrevemos os objetivos; na quarta, a tese; na quinta identificamos a metodologia utilizada; e na sexta coluna, as principais conclusões.

Na sequência, apresentamos uma discussão para cada uma das quatro categorias de artigos e, ao final, a discussão geral da revisão. As tabelas dos artigos são apresentadas a cada seção, seguidas de análises e observações acerca do conteúdo contido em cada uma delas. 


\subsubsection{A primeira categoria de artigos: afetividade, atitude e motivação em relação à}

\section{Matemática}

Tabela 1 - Artigos Sobre Afetividade, Atitude e Motivação em Relação à Matemática.

\begin{tabular}{|c|c|c|c|c|c|}
\hline$\overline{\mathrm{N}}{ }^{\mathrm{o}}$ & $\begin{array}{l}\text { Referência } \\
\text { completa }\end{array}$ & Objetivos & Tese & Método & Conclusões \\
\hline 1 & $\begin{array}{l}\text { Bzuneck, J. A., } \\
\text { Megliato, J. G. } \\
\text { P., \& Rufini, S. } \\
\text { (2013). } \\
\text { Engajamento de } \\
\text { adolescentes nas } \\
\text { tarefas escolares } \\
\text { de casa: uma } \\
\text { abordagem } \\
\text { centrada na } \\
\text { pessoa. Revista } \\
\text { Semestral da } \\
\text { Associação } \\
\text { Brasileira de } \\
\text { Psicologia }\end{array}$ & $\begin{array}{l}\text { Identificar relações } \\
\text { entre uso de } \\
\text { estratégias de } \\
\text { aprendizagem e } \\
\text { perfis motivacionais } \\
\text { de adolescentes na } \\
\text { realização de tarefas } \\
\text { de casa na disciplina } \\
\text { de Matemática. }\end{array}$ & $\begin{array}{l}\text { A qualidade } \\
\text { motivacional para } \\
\text { tarefas de casa de } \\
\text { Matemática deve } \\
\text { diferir daquelas de } \\
\text { sala de aula } \\
\text { devido às } \\
\text { características } \\
\text { desse tipo de } \\
\text { tarefa e do } \\
\text { contexto onde é } \\
\text { realizada. }\end{array}$ & $\begin{array}{l}513 \text { estudantes } \\
\text { de } 7^{\mathrm{a}} \text { e } 8^{\mathrm{a}} \text { séries } \\
\text { do Ensino } \\
\text { Fundamental } \\
\text { de escolas } \\
\text { públicas entre } \\
12 \text { e } 16 \text { anos. } \\
\text { Responderam a } \\
\text { um } \\
\text { questionário } \\
\text { sobre o } \\
\text { engajamento } \\
\text { cognitivo nas } \\
\text { tarefas de casa } \\
\text { de Matemática. }\end{array}$ & $\begin{array}{l}\text { Alunos menos } \\
\text { motivados } \\
\text { apresentaram } \\
\text { escores mais baixos } \\
\text { em estratégias } \\
\text { metacognitivas e } \\
\text { mais altas em falta } \\
\text { de persistência e } \\
\text { gerenciamento e } \\
\text { foram considerados } \\
\text { menos adaptados às } \\
\text { atividades de casa } \\
\text { de Matemática. Ao } \\
\text { contrário de alunos } \\
\text { motivados. }\end{array}$ \\
\hline
\end{tabular}

Escolar e

Educacional, 17,

151-161.

2 Otaviano, A. B.

Investigar a

percepção de alunos

do Ensino Médio em

relação à utilização

M, L, S., \&

Fukuda, C. C.

(2012). Estímulo

à criatividade

por professores

de Matemática e

motivação do

aluno. Revista

Semestral da

Associação

Brasileira de

Psicologia

Escolar e

Educacional, 16,

61-69.

3 Fuentes, V. L.

de práticas

favoráveis ao

desenvolvimento da

criatividade $\mathrm{e}$

motivação por seus

professores na

disciplina de

Matemática.

Professores devem fundamentar o trabalho da

Matemática em situações vivenciadas pelos alunos no cotidiano, para que esses possam criar seus próprios meios de resolução de problemas.

$\begin{array}{ll}\begin{array}{l}\text { A decisão de } \\ \text { selecionar }\end{array} & \begin{array}{l}\text { 159 estudantes } \\ \text { do curso de } \\ \text { estratégias de } \\ \text { ensino deve-se } \\ \text { considerar não }\end{array} \\ \text { somente os } & \text { foração } \\ \text { conteúdos, mas } & \text { interrogados } \\ \text { também as } & \text { por meio do } \\ \text { características } & \text { sobre a } \\ \text { individuais dos } & \text { predisposição e } \\ \text { alunos. } & \text { atitude em } \\ & \text { relação à }\end{array}$

P., Lima, R., \&

Guerra, D. S.

(2009). Atitudes

em relação à

Matemática em

estudantes de

Administração.

Conhecer a

predisposição dos

alunos de um curso

de administração em

relação à

Matemática, e o

enfoque utilizado

nos estudos.

A decisão de ionar ensino deve-se considerar não somente os conteúdos, mas também as características

Semestral da

Associação

Brasileira de
396 estudantes do $2^{\circ}$ ano do Ensino Médio de duas escolas, uma pública e outra particular responderam dois questionários. Houve, ainda, a coleta das notas dos alunos, do diário de classe. relação à
Alunos de escolas particulares avaliam mais positivamente seus professores em relação ao incentivo ao desenvolvimento de novas ideias. Professores da escola pública utilizam poucas estratégias que favoreçam a criatividade dos alunos.

Os alunos que mais demonstraram atitude positiva em relação a Matemática foram aqueles que preferiam as áreas de exatas no tempo de escola. Alunos que tinham um enfoque de estudo mais profundo 
Psicologia

Escolare

Educacional, 13, 133-141.

Coelho, J. P. (2008). Sucesso e insucesso na Matemática no final da escolaridade obrigatória, eis a questão! Análise Psicológica, 26, 663-678.

5 Faria P. C., Moro M. L. F., \& Brito, M. R. F. (2008).

Atitudes de professores e futuros professores em relação à Matemática.

Estudos de Psicologia, 13, 257-265.
Compreender de que forma os resultados em Matemática são influenciados por fatores sociais e familiares.

Propiciar uma
ampliação do
conhecimento a
respeito do tema da
atitude em relação à
Matemática e sua
importância na
formação do
professor.

Situações

favoráveis ao desenvolvimento de atitudes positivas em relação à Matemática não são frequentemente vivenciadas na formação do professor nem no exercício da atividade docente.

Os aspectos afetivos desempenham um papel primordial no sucesso de alunos, principalmente da Matemática.

Professores não levam em conta esses fatores, provavelmente por falta de relevância dada a esse aspecto na sua formação. disciplina de

Matemática

Financeira, em

uma pesquisa

de

delineamento

transversal.

675 alunos dos

$7^{\circ}, 8^{\circ}$ e $9^{\circ}$ anos

em Portugal

responderam a

2 questionários

sobre a sua

percepção em

relação aos

pais,

professores,

colegas e

carreira futura

440 pessoas

entre

professores e

estudantes do

curso de

Matemática

responderam

um

questionário.

Aquelas 10 que obtiveram

melhores e

piores

resultados no

questionário

participaram de

uma entrevista.

8 alunos do $8^{\circ}$

ano

participaram de

uma pesquisa

dividida em 3

etapas,

observação

presencial e

gravação de

vídeo de oito

aulas, aplicação

de 3

questionários e

2 entrevistas.

apresentaram

atitudes mais

positivas em

relação à

Matemática.

Fatores positivos

para os resultados

em Matemática: o

apoio da mãe e dos

professores. Fatores

negativos:

reprovação e

estudar Matemática

em um país

estrangeiro.

A atitude do aluno muda de positiva,

ao ingressar na graduação, para negativa no final da graduação e início da carreira como docente. A escolha da licenciatura pode ser influenciada pelos bons resultados na Matemática escolar.

A afetividade está ligada ao desempenho dos alunos. As crenças dos alunos em relação à

Matemática refletem em seu desempenho. Muitos preferem decorar regras e formulas ao invés de em vez de se empreenderem em refletir conceitualmente sobre os problemas. O acompanhamento dos pais diminui a ansiedade dos alunos. 
Loos, H. (2004).

Ansiedade e aprendizagem: um estudo com díades resolvendo problemas algébricos. Estudos de Psicologia, 9, 563-573.
Observar como Os aspectos estudantes de $6^{\mathrm{a}}$ e $7^{\mathrm{a}}$ séries gerenciavam, concomitantemente à busca de solução para problemas algébricos, a relação interpessoal e a ansiedade. afetivos dos alunos em relação a Matemática devem ser levados em conta, nas sessões de resolução de problemas de Matemática.
16 alunos de $6^{\mathrm{a}}$ e $7^{\mathrm{a}}$ séries, em dupla, descreveram o raciocínio utilizado em sessões de resolução de problemas algébricos. Foram avaliados por testes clínicos: como o IDATE (Inventário de Ansiedade Traço-Estado) e o Teste de Zulliger.
Em todos os casos houve geração de ansiedade por conta das dificuldades das tarefas. A ansiedade foi facilmente administrada nas duplas onde houve uma boa interação. Não foi contida naquelas duplas que apresentaram dificuldades com a compreensão dos conteúdos.

$\mathrm{Na}$ primeira categoria analisada, incluímos artigos que abordaram o desempenho em Matemática, influenciado por questões ligadas à afetividade. São discutidos os seguintes aspectos: diferenças de gênero no desempenho da Matemática; atitudes relativas à Matemática e motivação e ansiedade durante a realização de tarefas matemáticas escolares.

Todos os artigos dessa categoria são de natureza empírica. Destes, $71,42 \%$ são relativos a estudos quantitativos, nos quais houve a predominância do uso de questionários, testes psicológicos e análise estatística dos dados. 28,5\% são relativos a estudos qualitativos, nos quais foram realizadas observações, sessões de interação, gravação das atividades em áudio e vídeo, e análise e interpretação dos significados dos comportamentos dos participantes. Do total de artigos, $71 \%$ se concentraram na investigação de participantes adolescentes e 19\% de estudantes do ensino superior (cursos de graduação).

Entre as abordagens teóricas identificadas, percebemos poucas referências à relação entre desenvolvimento cognitivo e desenvolvimento afetivo. Apenas o artigo de Loos (2004) se propôs explicitamente a discutir essa relação. Nele encontramos referências às 
obras Introduction de l'algèbre auprès de débutants faibles: problèmes épistemologiques et didactiques, de Vergnaud, Cortes e Favre e Artigue (1987); aos Estudos Sociológicos, de Piaget (1965); ao Desenvolvimento Social da Inteligência, de Doise e Mugny (1981); e também aos Obstáculos Epistemológicos dos Problemas na Matemática, de Brousseau (1983).

No aspecto relacionado às diferenças de gênero, os artigos de Bzuneck, (2013) e Coelho (2008) apresentam elementos descritos na literatura que tentam justificar uma possível vantagem intelectual dos homens em relação às mulheres na aprendizagem matemática. Entre elas, destacam-se duas: 1) as mulheres são mais desmotivadas para a aprendizagem nessa área do conhecimento; 2) as famílias e professores veiculam às mulheres a crença de que são menos capazes para a aprendizagem matemática do que os homens. Os autores, contudo, ponderam que não há dados suficientes que possam comprovar diferenças cognitivas para a aprendizagem, baseando-se nas diferenças de gênero.

Outro aspecto discutido pelos artigos diz respeito à atitude em relação à Matemática. Discute-se, principalmente, a escolha da profissão mediante afinidade ou não com a Matemática no tempo de escola (Faria, Moro \& Brito, 2008; Fuentes, Lima \& Guerra 2009). Faria et al., (2008) constataram que alguns universitários decidiram cursar licenciatura em Matemática, motivados por experiências escolares positivas em relação a essa disciplina. Dados semelhantes foram descritos por Fuentes et al., (2009) sobre jovens que apreciavam a disciplina Matemática Financeira na universidade. Assim como aqueles jovens apontados na pesquisa anterior, esses também afirmaram ter obtido bons resultados na Matemática nos anos escolares.

As relações de afetividade aparecem nos artigos relacionados à questão do desempenho escolar. Segundo Neves e Carvalho (2006), por exemplo, o desempenho em 
Matemática é influenciado pelas relações de afetividade que se estabelecem entre os alunos, seus colegas, pais e professores. Para os autores, são requisitos para o sucesso na aprendizagem as experiências positivas, como, o apoio dos professores aos alunos (mediação de confiança) e a participação efetiva dos pais na vida escolar dos filhos, bem como uma boa interação com os seus colegas durante as resoluções matemáticas.

Nos artigos analisados, é apontada, ainda, a relação existente entre motivação e criatividade. Otaviano, Alencar e Fukuda (2012) salientaram que o ensino centrado no professor não encoraja a criatividade dos alunos, o que pode causar desmotivação para o ato de aprender. Segundo essas autoras, um exemplo de criatividade, nesse caso, é a produção de notações próprias por parte dos alunos na resolução de questões matemáticas. Segundo elas, não permitir vez ou voz, na sala de aula, pode gerar ou reforçar comportamentos ansiosos, devido ao medo de errar. De acordo com Loos (2004), a ansiedade pode se configurar em um fator relevante para os maus resultados, durante a resolução de problemas algébricos. Segundo a autora, quando os alunos são capazes de gerenciar a ansiedade, os seus desempenhos melhoram significativamente. Ela alerta, porém, que caso os alunos não tenham esquemas mentais desenvolvidos para os conceitos envolvidos nas questões a ser resolvidas, mesmo controlando a ansiedade, o bom desempenho não se fará presente.

Segundo Bzuneck et al. (2013), a ausência de motivação aparece predominantemente entre os adolescentes. Esses autores afirmam que, dentre as diversas faixas etárias de alunos, os que mais apresentam índices de desmotivação, no contexto escolar, são os adolescentes, especialmente na disciplina de Matemática. Esse dado, talvez, justifique o porquê de os estudos desta categoria concentrarem-se principalmente na investigação de indivíduos jovens ou adolescentes. Para concluir essa análise, apontamos como consenso dessa categoria a defesa de que a motivação, tanto intrínseca, como 
extrínseca, além de outros fatores ligados a afetividade são determinantes para os resultados dos indivíduos na Matemática. 


\subsubsection{A segunda categoria de artigos: o ensino da Matemática e o desenvolvimento}

\section{atípico}

Tabela 2 - Artigos da categoria Matemática e necessidades educacionais especiais

\begin{tabular}{|c|c|c|c|c|c|}
\hline $\mathbf{N}^{\mathbf{0}}$ & $\begin{array}{l}\text { Referência } \\
\text { completa }\end{array}$ & $\begin{array}{l}\text { Objetivos do } \\
\text { estudo }\end{array}$ & Tese & Método & Conclusões \\
\hline 1 & $\begin{array}{l}\text { Barbosa, H. H. } \\
\text { (2014). Conceitos } \\
\text { matemáticos } \\
\text { iniciais e } \\
\text { linguagem: um } \\
\text { estudo } \\
\text { comparativo entre } \\
\text { crianças surdas e } \\
\text { ouvintes. } \\
\text { Educação e } \\
\text { Pesquisa, 40, 163- } \\
179 .\end{array}$ & $\begin{array}{l}\text { Investigar o } \\
\text { desempenho de } \\
\text { crianças surdas } \\
\text { e ouvintes da } \\
\text { educação } \\
\text { infantil, em } \\
\text { relação a vários } \\
\text { aspectos } \\
\text { relativos à } \\
\text { conceituação } \\
\text { quantitativa- } \\
\text { numérica. }\end{array}$ & $\begin{array}{l}\text { Crianças surdas } \\
\text { apresentam o } \\
\text { mesmo } \\
\text { desempenho de } \\
\text { crianças ouvintes } \\
\text { quando as } \\
\text { habilidades } \\
\text { Matemáticas são } \\
\text { mais dependentes } \\
\text { do estímulo } \\
\text { linguístico. }\end{array}$ & $\begin{array}{l}43 \text { crianças da } \\
\text { educação infantil, } \\
\text { destas } 32 \text { ouvintes } \\
\text { e } 11 \text { surdas, } \\
\text { participaram da } \\
\text { pesquisa. Foram } \\
\text { feitas entrevistas } \\
\text { clínicas individuais } \\
\text { em } 2 \text { sessões, } \\
\text { utilizando como } \\
\text { ferramentas tarefas } \\
\text { formuladas para } \\
\text { investigar } \\
\text { habilidades e } \\
\text { procedimentos } \\
\text { matemáticos } \\
\text { iniciais. }\end{array}$ & $\begin{array}{l}\text { As crianças surdas } \\
\text { e as ouvintes } \\
\text { apresentam } \\
\text { desempenho } \\
\text { semelhante no que } \\
\text { se refere a } \\
\text { habilidades } \\
\text { numéricas e } \\
\text { quantitativas de } \\
\text { base não simbólica. }\end{array}$ \\
\hline 2 & $\begin{array}{l}\text { Cechi, M. B. C., } \\
\text { Costa, A. C., \& } \\
\text { Dorneles, B. V. } \\
\text { (2013). Ensino de } \\
\text { Fatos Aritméticos } \\
\text { para Escolares } \\
\text { com Deficiência } \\
\text { Intelectual. Revista } \\
\text { Brasileira de } \\
\text { Educação } \\
\text { Especial, 19, 79- } \\
\text { 92. }\end{array}$ & $\begin{array}{l}\text { Verificar os } \\
\text { efeitos do } \\
\text { programa de } \\
\text { intervenção } \\
\text { direcionado ao } \\
\text { ensino de fatos } \\
\text { aritméticos } \\
\text { junto a crianças } \\
\text { com deficiência } \\
\text { intelectual. }\end{array}$ & $\begin{array}{l}\text { A intervenção a } \\
\text { partir da } \\
\text { abordagem do } \\
\text { ensino direto se } \\
\text { mostrou eficaz } \\
\text { para o ensino de } \\
\text { crianças com } \\
\text { necessidades } \\
\text { especiais e } \\
\text { transtorno de } \\
\text { aprendizagem. O } \\
\text { ensino direto } \\
\text { oferece benefícios } \\
\text { para } \\
\text { aprendizagens } \\
\text { futuras. }\end{array}$ & $\begin{array}{l}3 \text { sujeitos com } \\
\text { diagnóstico de } \\
\text { Deficiência } \\
\text { Intelectual } \\
\text { resolveram } \\
\text { problemas aditivos } \\
\text { utilizando a } \\
\text { estratégia que } \\
\text { quisessem no } \\
\text { menor tempo } \\
\text { possível. Houve } \\
\text { uma avaliação pré } \\
\text { e pós-teste de um } \\
\text { programa de } \\
\text { intervenção com } \\
\text { 10 encontros. A } \\
\text { intervenção se } \\
\text { estruturou a partir } \\
\text { de ciclos de ensino } \\
\text { de um novo } \\
\text { procedimento de } \\
\text { contagem. }\end{array}$ & $\begin{array}{l}\text { Concluiu-se que a } \\
\text { intervenção } \\
\text { proposta nesse } \\
\text { estudo foi eficaz } \\
\text { para os alunos com } \\
\text { DI no que se refere } \\
\text { ao avanço das } \\
\text { estratégias de } \\
\text { contagem. Sugere } \\
\text { ainda que uma } \\
\text { proposta de ensino } \\
\text { com base nessa } \\
\text { abordagem seja } \\
\text { criada, com a } \\
\text { finalidade de } \\
\text { atender crianças } \\
\text { com Deficiência } \\
\text { Intelectual. }\end{array}$ \\
\hline 3 & $\begin{array}{l}\text { Rosso, T. R. F., \& } \\
\text { Dorneles, B. V. } \\
\text { (2012). Contagem } \\
\text { numérica em } \\
\text { estudantes com } \\
\text { síndromes de X- } \\
\text { Frágil e Prader- } \\
\text { Willi. Revista } \\
\text { Brasileira de }\end{array}$ & $\begin{array}{l}\text { Investigar as } \\
\text { características } \\
\text { da contagem } \\
\text { numérica em } \\
\text { alunos com } \\
\text { Síndrome de } \\
\text { Prader-Willi e } \\
\text { Síndrome do X- }\end{array}$ & $\begin{array}{l}\text { É importante } \\
\text { propiciar às } \\
\text { crianças } \\
\text { intervenções } \\
\text { adequadas, já nos } \\
\text { primeiros anos de } \\
\text { escolarização, } \\
\text { para minimizar } \\
\text { dificuldades na }\end{array}$ & $\begin{array}{l}2 \text { alunos, um com } \\
\text { síndrome de Prader } \\
\text { Willi e síndrome } \\
\text { do X Frágil foram } \\
\text { observados em um } \\
\text { período de dois } \\
\text { meses (6 } \\
\text { encontros). Em um } \\
\text { dos encontros }\end{array}$ & $\begin{array}{l}\text { O aluno com } \\
\text { Síndrome do X- } \\
\text { Frágil escreveu, } \\
\text { contou e nomeou } \\
\text { os números até } 15 . \\
\text { O sujeito com } \\
\text { síndrome de Prader } \\
\text { Willi nomeou com } \\
\text { dificuldade de } 1 \text { até }\end{array}$ \\
\hline
\end{tabular}




\author{
Educação \\ Especial, 18, 231- \\ 244. \\ Frágil.
}

4 Silva, P. A., \&

Santos, F. H.

(2011). Discalculia

do

desenvolvimento:

Avaliação da

representação

numérica pela

Zareki-R.

Psicologia: Teoria

e Pesquisa, 27,

169-177.

Descrever um
estudo sobre a
utilização de
Zareki-R e
tarefas de
memória
operacional, na
identificação de
quais aspectos
da
representação
numérica e
memória
operacional
podem explicar
dificuldades
aritméticas em
crianças.

Crianças com

dificuldades em

aritmética têm

dificuldades em

cálculos e em

tarefas que

avaliam o

processamento

numérico.

Acredita-se que

essas crianças

apresentem

prejuízos globais

em representação

numérica e

prejuízos

específicos em

memória

operacional.
5 Rodrigues, C. I.,

Sousa, M. C., \&

Carmo, J. S.

(2010). Transtorno

de conduta TDAH

e aprendizagem da

Matemática: um

estudo de caso.

Revista Semestral

da Associação

Brasileira de

Psicologia Escolar

e Educacional

(ABRAPEE), 14,

193-201.

6 Rossit, R. A. S., \& Goyos, C. (2009).

Deficiência

intelectual e

aquisição

matemática:

currículo como

rede de relações

condicionais.

Revista Semestral

da Associação

Brasileira de
Descrever um

estudo de caso

com um aluno

diagnosticado

como tendo

Transtorno de

Conduta

associado a

Transtorno de

Déficit de

Atenção e

Hiperatividade

e com

dificuldades

acentuadas na

Matemática.

Analisar a

aquisição de

relações

matemáticas e

apresentar um

currículo

baseado no

paradigma de

equivalência de

estímulos para

ensinar

deficientes
A aprendizagem

da Matemática e

de seus conteúdos

pode ser

prejudicada pelo

Transtorno de

conduta e

transtorno de

déficit de atenção

e hiperatividade.

Acredita-se que os deficientes

intelectuais

esquecem o que

lhes é ensinado,

pois a deficiência

causa uma

aprendizagem

pouca retenção.

No entanto essa

condição deve-se

mais a problemas foram submetidos

a investigação dos

cinco princípios de

contagem de

Gellmam e

Gallistell (1978).

Participaram 30

crianças divididas

em 2 grupos, um

com dificuldades

na aritmética e

outro sem. Foram

avaliadas pelo

TDE (teste de

desenvolvimento

escolar), Matrizes

progressivas

coloridas de

Raven, BCPR

(Teste de repetição

de Pseudopalavras

para crianças

brasileiras), Bloco

de Corsi, Span de

Dígitos e ZAreki-

$\mathrm{R}$, além de terem

sido realizadas

anamneses com os

pais das crianças.

1 crianças de 9

anos com

diagnostico de

Transtorno de

Conduta associado

ao Transtorno de

Déficit de atenção

e hiperatividade

Instrumentos de

coleta de dados: a

observação

participante,

entrevista com a

professora do

aluno, diretora da

escola e análise de

diário de classe.

11 pessoas com

deficiências

intelectual, entre 9

e 32 anos,

participaram de um

pré-teste, de um o

treino de relações

condicionais, da

aplicação de testes

imediatos e de

testes de

manutenção. Os
10. Ambos

demonstraram estar

em processo de

construção da

correspondência

termo a termo.

O grupo de

crianças com

dificuldades de

aprendizagem

obteve resultados

inferiores aos sem

dificuldade de

aprendizagem na

maioria dos testes.

Devido a

dificuldades na

representação

numérica tanto em

cálculo como no

processamento

numérico

simbólico, essas

crianças

apresentaram perfil

compatível com a

discalculia do

desenvolvimento.

Percebeu-se que o

aluno raciocinava

de forma correta

mas a resposta em

geral estava

incorreta. Com

base no estudo

levantou-se a

hipótese de que as

dificuldades do

aluno decorriam de não ter adquirido a

noção de sistema

posicional e não de

sua condição

orgânica.

Os participantes

formaram classes

extensas de

estímulos

equivalentes $\mathrm{e}$

expandiram para

valores não

trabalhados. Os

objetivos propostos

para a intervenção

em questão foram

atingidos e os 
Psicologia Escolar e Educacional (ABRAPEE), 13, intelectuais no manuseio de dinheiro. 213-225.

Araújo, P. M., \& Ferreira, P. R. S. (2008). Ensinando subtração para pessoas com deficiência mental com base em relações de equivalência de estímulos.

Psicologia: teoria e pesquisa, 24, 313-322.

8 Gomes, C. G. S. (2007). Autismo e ensino de

habilidades acadêmicas: adição e subtração. Revista Brasileira de Educação Especial, 13, 345364.

\begin{abstract}
Apresentar um estudo realizado com pessoas com deficiência mental para avaliar um procedimento para o ensino de subtração.
\end{abstract}

Descrever o ensino de habilidades de adição e subtração a uma adolescente autista. na programação instrucional.

A análise do comportamento mostra-se como um importante recurso para o ensino, gerando procedimentos para ensinar comportamentos matemáticos a crianças com ou sem deficiência mental.

Com a melhoria de estratégias de ensino, crianças com autismo tem mostrado um ganho no repertório geral tornando-se mais hábeis ao aprender conhecimentos complexos.

Discutir a relação entre pensamento e linguagem e a língua brasileira de sinais, em um estudo sobre a resolução de situações problema de

\section{Matemática.}

Fávero, M. H., \& Pimenta, M. L. (2006).

Pensamento

língua de sinais na resolução de problemas.

Psicologia:

Reflexão e crítica, 19, 225-236. dados foram

analisados por

porcentagem de

acertos e formação

de classes de

equivalência.

3 pessoas com

deficiência mental

entre 15 e 35 anos

foram expostos a

estímulos auditivo-

visuais e visuais-

visuais e em

seguida

participavam de

um programa de

ensino constituído

de pré-teste, treino

e pós-teste.

Uma menina de 12 anos com autismo

participou de

sessões de ensino

em consultório de

psicologia uma vez

por semana com

duração de 50

minutos baseados

nos princípios da

abordagem da

análise do

comportamento e

atividades em casa.

Participaram

alunos entre 18 e

30 anos de idade

da educação de

jovens e adultos

que eram surdos. $\mathrm{O}$

estudo se

desenvolveu em

três fase. 1)

avaliação de

competências dos

sujeitos, 2)

pesquisa sobre os termos utilizados para a comparação de conjuntos na

língua de sinais, 3 )

proposição de uma situação-problema. resultados

apresentados pelos

indivíduos

surpreenderam

educadores e

pesquisadores.

Os resultados

indicaram que a

estratégia adotada

foi eficaz a todos os

participantes e que

o ensino de alguns

valores fez surgir

outros. Isso

permitiu aos

indivíduos a

ampliação dos

conhecimentos

relacionados à

subtração.

A organização visual das tarefas permitiu que a aluna pudesse olhar os estímulos necessários para a resolução e assim conseguir acertar as operações. Ao final das sessões de ensino a

adolescente obteve $100 \%$ de acertos nas atividades envolvendo adição e subtração.

Para que haja uma prática

psicopedagógica de resultados positivos para alunos surdos,

há a necessidade de o professor ser

fluente em libras e que as atividades façam sentido para os sujeitos. Deve ser permitido também que possam vivenciar experiências a partir das várias funções do número. A qualidade da mediação semiótica interfere na aquisição dos conhecimentos. 
Nesta categoria, estão descritos artigos sobre Matemática e desenvolvimento atípico. São salientados estudos sobre a surdez, o autismo, a deficiência intelectual, as síndromes de Prader Willi e do X-Frágil, a discalculia do desenvolvimento e os transtornos (associados) de conduta e hiperatividade. A análise permitiu identificar dois aspectos recorrentes nesta categoria. O primeiro deles é referente à importância de o professor conhecer e compreender os processos de construção dos conceitos matemáticos por seus alunos. O segundo aspecto evidenciado, é aquele relacionado às estratégias de intervenção que podem favorecer o desenvolvimento de aquisições matemáticas.

Dos 9 artigos listados nesta categoria, todos referem-se a relatos de pesquisas. $40 \%$ constituem-se de pesquisas qualitativas, nas quais predominou os estudos de intervenção, atividades de ensino, treino de habilidades matemáticas, entrevistas e observações. Neles evidenciamos a larga presença do modelo de pesquisa baseado no pré-teste, intervenção e pós-teste. $50 \%$ dos artigos são relativos a estudos quantitativos, que se basearam prioritariamente no uso de testes psicológicos e na análise estatística de dados; e um dos principais focos desses estudos se referia à memória. Nesta categoria, diferentemente da categoria 1, houve uma diversidade entre os participantes identificados, pois se pode verificar a participação de crianças, adolescentes, jovens e adultos.

Um ponto a ser salientado, nesta categoria, é que a maioria dos estudos analisados é referente à aprendizagem de conceitos matemáticos elementares, tais como: a contagem numérica, a adição e a subtração. Do conjunto observado, apenas o estudo de Fávero e Pimenta (2006) realizado com pessoas surdas amplia esses conteúdos e apresenta atividades nas quais os participantes manipularam conceitos das quatro operações aritméticas e também conceitos mais complexos, como os números decimais.

Entre as abordagens teóricas mais utilizadas, foi percebida a predominância dos estudos da Equivalência de Estímulos e de Abordagem Experimental do Comportamento. 
Os poucos trabalhos que não utilizaram estas abordagens, basearam-se, por exemplo, nos estudos de Gelmam e Gallistell (1978, 1990), de Vergnaud (1991) e de Nunes e Bryant (1996).

Quanto ao aspecto da mediação escolar, dois pontos podem ser destacados. O primeiro deles retoma o fato de que, cada vez mais, crianças com desenvolvimento atípico estão ingressando nas escolas de ensino regular. Segundo os autores, isso requer dos docentes o conhecimento de como ocorrem os processos de aquisição e construção de competências matemáticas. Eles defendem que esse conhecimento subsidia um efetivo planejamento de estratégias de intervenção, com base nas reais necessidades dos alunos (Rossit \& Goyos, 2009; Rosso \& Dornelles, 2012; Fávero \& Pimenta, 2006).

Outro ponto relativo à mediação escolar é aquele referente às dificuldades de aprendizagem. Autores como Fávero e Pimenta (2006) e Rodrigues, Sousa e Carmo (2010) mostram que possíveis dificuldades desses alunos estão mais relacionadas às questões de mediação dos conteúdos escolares do que ao diagnóstico desses indivíduos. Rodrigues et al. (2010) apontaram, em seu estudo junto a um indivíduo diagnosticado com TC/TDAH, que as suas dificuldades em relação ao registro das operações matemáticas estavam relacionadas a dificuldades com a compreensão do Sistema de Numeração Decimal. Ao resolver as operações, suas verbalizações eram corretas, mas o registro se mostrava incorreto. Sendo assim, há indícios de que as dificuldades matemáticas escolares de crianças com desenvolvimento típico ou atípico são semelhantes e estão relacionadas à compreensão da lógica do Sistema de Numeração Decimal (Fávero, 2009a; Fávero, 2009b).

Os artigos desta categoria também apresentaram outro aspecto relevante para esta análise, que é aquele referente à intervenção. Gomes (2007) descreveu um estudo com uma adolescente autista que aprendeu a utilizar o registro da adição e da subtração e expandiu 
seu conhecimento matemático a conceitos mais complexos. Nesse sentido, estudos envolvendo pessoas com deficiência intelectual, síndromes, deficiência auditiva (Fávero \& Pimenta, 2006; Gomes, 2007; Araújo \& Ferreira, 2008) têm mostrado que alunos com desenvolvimento atípico desenvolvem competências numéricas. Esses estudos apontam como consenso o fato de que os alunos com desenvolvimento atípico podem, além de desenvolver competências matemáticas, ampliar os seus conhecimentos em razão da mediação que lhes é oferecida. 


\subsubsection{A terceira categoria de artigos: processos de aquisição de competências}

\section{matemáticas}

Tabela 3 - Artigos sobre processos de aquisição de competências matemáticas.

\begin{tabular}{|c|c|c|c|c|c|}
\hline $\mathbf{N}^{\mathbf{0}}$ & $\begin{array}{l}\text { Referência } \\
\text { completa }\end{array}$ & $\begin{array}{l}\text { Objetivos do } \\
\text { estudo }\end{array}$ & Tese & Método & Conclusões \\
\hline 1 & $\begin{array}{l}\text { Cruz, V. (2014). } \\
\text { Desenvolviment } \\
\text { o cognitivo e } \\
\text { aprendizagem } \\
\text { da Matemática. } \\
\text { Análise } \\
\text { Psicológica, } 1 \text {, } \\
\text { 127-132. }\end{array}$ & $\begin{array}{l}\text { Abordar a } \\
\text { construção da } \\
\text { Matemática e } \\
\text { enquadrá-la no } \\
\text { contexto da } \\
\text { hierarquia da } \\
\text { linguagem. }\end{array}$ & $\begin{array}{l}\text { A linguagem } \\
\text { matemática } \\
\text { resulta da } \\
\text { evolução tanto } \\
\text { cognitiva como } \\
\text { linguística dos } \\
\text { seres humano e } \\
\text { de conquistas } \\
\text { ao longo do } \\
\text { crescimento da } \\
\text { criança. }\end{array}$ & $\begin{array}{l}\text { Situa a } \\
\text { linguagem } \\
\text { matemática, faz } \\
\text { referência à } \\
\text { elaboração } \\
\text { dessa } \\
\text { linguagem } \\
\text { enfatizando a } \\
\text { aritmética e } \\
\text { expõe } \\
\text { preocupações } \\
\text { sobre o ensino } \\
\text { da Matemática. }\end{array}$ & $\begin{array}{l}\text { O estudo da } \\
\text { Matemática não } \\
\text { pode se pautar } \\
\text { pela aplicação } \\
\text { de leis. Ela é } \\
\text { antes de tudo } \\
\text { um corpo em } \\
\text { constante } \\
\text { transformação. }\end{array}$ \\
\hline 2 & $\begin{array}{l}\text { Lorena, A. B., } \\
\text { Castro- } \\
\text { Caneguim, J. F., } \\
\text { \& Carmo, J. S. } \\
\text { (2013). } \\
\text { Habilidades } \\
\text { numéricas } \\
\text { básicas: } \\
\text { Algumas } \\
\text { contribuições da } \\
\text { análise do } \\
\text { Comportamento } \\
\text {. Estudos de } \\
\text { Psicologia, 18, } \\
\text { 439-446. }\end{array}$ & $\begin{array}{l}\text { Oferecer alguns } \\
\text { dados } \\
\text { fundamentais } \\
\text { sobre a aquisição } \\
\text { de habilidades } \\
\text { numéricas } \\
\text { básicas, } \\
\text { discutindo-os a } \\
\text { partir do } \\
\text { referencial da } \\
\text { Análise do } \\
\text { Comportamento, } \\
\text { com base numa } \\
\text { breve revisão de } \\
\text { literatura. }\end{array}$ & $\begin{array}{l}\text { Habilidades } \\
\text { numéricas } \\
\text { básicas são } \\
\text { necessárias } \\
\text { para o } \\
\text { aprendizado da } \\
\text { Matemática, } \\
\text { estando entre } \\
\text { elas: o senso } \\
\text { numérico, a } \\
\text { contagem a } \\
\text { subitização, e } \\
\text { as relações do } \\
\text { comportamento } \\
\text { conceitual } \\
\text { numérico. }\end{array}$ & $\begin{array}{l}\text { Inicialmente } \\
\text { apresenta uma } \\
\text { análise de } \\
\text { estudos sobre o } \\
\text { senso } \\
\text { numérico, a } \\
\text { subitização e a } \\
\text { contagem. Em } \\
\text { seguida é } \\
\text { apresentada } \\
\text { uma proposta } \\
\text { de tratamento } \\
\text { do conceito de } \\
\text { número e as } \\
\text { implicações } \\
\text { para o meio } \\
\text { educacional. }\end{array}$ & $\begin{array}{l}\text { A utilização de } \\
\text { controle de } \\
\text { estímulos e } \\
\text { equivalência } \\
\text { tem sido eficaz } \\
\text { na aquisição de } \\
\text { repertório } \\
\text { matemático. }\end{array}$ \\
\hline 3 & $\begin{array}{l}\text { Loth, M. H. M., } \\
\text { \& Silva, A. M. } \\
\text { (2013). Tarefas } \\
\text { Aritméticas } \\
\text { para o } 6^{\circ} \text { ano do } \\
\text { Ensino } \\
\text { Fundamental } \\
\text { Bolema, 27, } \\
451-465 .\end{array}$ & $\begin{array}{l}\text { Apresentar e } \\
\text { discutir um } \\
\text { produto } \\
\text { educacional } \\
\text { constituído por } \\
\text { tarefas de } \\
\text { Matemática, } \\
\text { baseadas em } \\
\text { situações- } \\
\text { problemas. }\end{array}$ & $\begin{array}{l}\text { Duas propostas } \\
\text { têm sido } \\
\text { negativas no } \\
\text { ensino da } \\
\text { Matemática, a } \\
\text { primeira têm } \\
\text { sido expor } \\
\text { alunos a } \\
\text { utilização de } \\
\text { fórmulas e } \\
\text { técnicas de } \\
\text { memorização e } \\
\text { a segunda } \\
\text { tolhê-los da na } \\
\text { criação de } \\
\text { estratégias } \\
\text { próprias de } \\
\text { resolução dos }\end{array}$ & $\begin{array}{l}\text { Um conjunto } \\
\text { de tarefas de } \\
\text { resolução } \\
\text { problemas para } \\
\text { o } 6^{\circ} \text { ano foi } \\
\text { apresentada a } \\
\text { duas duplas de } \\
\text { alunos do } 6^{\circ} \\
\text { ano. A sessão } \\
\text { foi filmada e } \\
\text { transcrita para a } \\
\text { análise do } \\
\text { significado das } \\
\text { produções dos } \\
\text { alunos. Depois, } \\
29 \text { alunos } \\
\text { resolveram as } \\
\text { tarefas para se }\end{array}$ & $\begin{array}{l}\text { Alunos } \\
\text { mostraram-se } \\
\text { empenhados na } \\
\text { resolução das } \\
\text { atividades e a } \\
\text { forma como } \\
\text { foram } \\
\text { apresentadas } \\
\text { estimulou a } \\
\text { produção de } \\
\text { significados. }\end{array}$ \\
\hline
\end{tabular}


problemas. avaliar a

eficácia do

produto das

tarefas.

Canal, C. P. P., Avaliar e

\& Queiroz, S. S. comparar (2012).

Procedimentos

de contagem de pontos em um

jogo com

conteúdo

matemático.

Revista

Semestral da

Associação

Brasileira de

Psicologia

Escolar e

Educacional,

16, 25-33. procedimentos

utilizados por

alunos de $7^{\circ}$ e $9^{\circ}$

anos durante a

realização de

operações

aritméticas com

números inteiros

na contagem de

pontos ao final

de um jogo.

Fávero, M. H., \& Pina Neves,

Apresentar, analisar e discutir R. S. (2012). A divisão e os racionais: uma pesquisa bibliográfica dos estudos revisão brasileiros e

bibliográfica e análise. internacionais centrados em

Zetetiké, 20, 33- números 66. racionais e divisão.

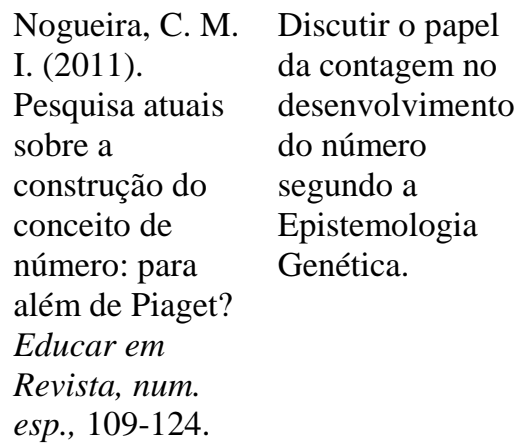

O jogo mostra-
se como um
importante
instrumento de
intervenção na
escola, pois
permite ao
aluno maior
liberdade e
proximidade
com a realidade
ou com o saber
em ato.
em ato. 


\begin{abstract}
Alberbaz, J. M. Aprimorar a (2009). Mapas de um percurso construído por crianças de 8 anos: interações e aprendizagens lógico-esp aciais.

Educação em

Revista, 25,

capacidade da criança de ler e representar mapas, a fim de servir de guia para outras capacidades e para a reflexão sobre relações geométricas.
\end{abstract} 103-122.

\section{Placha, K. C., \& Descrever a Moro, M. L. F. (2009). \\ Problemas de Produto \\ Cartesiano, \\ Raciocínio \\ Combinatório e Intervenção do \\ Professor. \\ Psicologia: \\ Teoria e \\ Pesquisa, 25, 007-017. \\ Descrever a soluções de crianças em problemas de produto cartesiano conforme níveis do raciocínio combinatório e identificar a aprendizagem e a sua natureza.}

Compreender o
espaço
geométrico
requer
conhecimentos
do espaço de
localização do
próprio sujeito
e do espaço
situado por ele
e outros.

Batista, A. M.

S. B., Spinillo,

A. G. (2008).

Nem todo

material

concreto é

igual: a

importância dos

referentes na

resolução de

problemas.

Estudos de

Psicologia, 13,

13-21.

Discutir como os
diferentes tipos
de material
concreto de
representação
influenciam a
resolução de
situações-
problemas de
multiplicação e
divisão.

Nem todo

material é

igual, há

aqueles que

favorecem mais

o desempenho

e o uso de

procedimentos

mais

apropriados que outros.

10 crianças
participaram de
um estudo de
caso no qual
foram

realizadas

observação

participativa,

registro de

diário de

campo,

filmagens das

atividades,

desenvolvidas

em 3 sessões.

5 crianças de

nove anos da $3^{\text {a }}$

série de uma

escola do

Ensino

Fundamental

participaram de

duas sessões

individuais de

resolução de 8

problemas, 4

por sessão, na

qual se adotou-

se o estilo

clínico-crítico,

os dados foram

gravados em

vídeo.

40 crianças de

8 anos,

divididas e, 2

grupos, um

com material

concreto

definido e outra

com material

concreto

indefinido,

foram

entrevistadas

em sessão

única na qual

deviam

resolver 2

problemas de

medidas e

explicar o

procedimento

usado.
As crianças

elaboraram

noções

espaciais para a

construção do

mapa. O

trabalho de

mediação dos

docentes

conduziu os

alunos à

reflexão sobre

as propriedades

do percurso

físico que

realizaram.

Houve

passagem de um nível menos avançado para um mais

avançado do raciocínio combinatório.

As crianças apresentaram diversas estratégias pessoais de cálculo na solução dos problemas propostos.

Crianças que utilizaram material concreto definido apresentaram melhores resultados que crianças que utilizaram material indefinido. A natureza do material interfere nos procedimentos de resolução das crianças. 
conhecimento

$\begin{array}{ll}\text { Lessa, M. M. } & \text { Retomar a } \\ \text { L., \& Falcão, J. } & \text { discussão acerca } \\ \text { T. R. (2005). } & \text { da relação entre } \\ \text { Pensamento e } & \text { pensamento e } \\ \text { Linguagem: } & \text { linguagem na } \\ \text { Discussão no } & \text { construção do } \\ \text { campo da } & \text { conhecimento } \\ \text { Psicologia da } & \text { matemático com } \\ \text { educação } & \text { ênfase na } \\ \text { Matemática. } & \text { álgebra. } \\ \text { Psicologia: } & \\ \text { reflexão e } & \\ \text { crítica, 18, 315- } & \\ \text { 322. } & \end{array}$

Bispo, R.,

Ramalho, G., \& Henriques, N. (2008) Tarefas matemáticas e desenvolviment o do matemático no $5^{\circ}$ ano de escolaridade. Análise

Psicológica, 26, 3-14.

Apresentar uma
discussão sobre
tarefas escolares
e o seu papel
como veículo
que favorece o
desenvolvimento
matemático.
tarefas de

Matemática resolvidas pelos alunos é fundamental ao estudo das práticas de ensino e à construção do conhecimento matemático.

Barbosa, H. H. J. (2007).

Sentido de número na infância: uma interconexão dinâmica entre conceitos e procedimentos. Paidéia, 17, 181-194.

Apresentar uma
revisão de
literatura sobre
processo de
desenvolvimento
do conceito de
sentido de
número pela
criança.

O sentido de número se coloca como um novo paradigma de pesquisa e ensino no campo da Matemática.

$\begin{array}{ll}\text { Moro, M. L. F. } & \begin{array}{l}\text { Descrever } \\ \text { concepções }\end{array} \\ \text { Estruturas } & \text { infantis da } \\ \text { Multiplicativas } & \text { divisão por } \\ \text { e Tomada de } & \text { partição. } \\ \text { Consciência: } & \text { Identificar níveis } \\ \text { Repartir para } & \text { de tomada de } \\ \text { Dividir. } & \text { consciência de } \\ \text { Psicologia } & \text { relações } \\ \text { Teoria e } & \text { referentes a } \\ \text { prática, 21, } & \text { divisão por }\end{array}$

Analisar as

A construção
de
competências
em ação,
teoremas em
ação e
esquemas, não
é mediada
apenas pela
linguagem.
linguagem.
Foram analisadas 337 tarefas de Matemática relativas a número e cálculo, elaboradas por 5 professores de Matemática e propostas a alunos do quinto ano de escolaridade de uma escola de Lisboa.

Revisão de literatura sobre a discussão em torno do sentido de número, seguida de uma revisão de estudos sobre bebês e o desenvolver cognitivo, discutindo a contagem e a cardinalidade.

40 estudantes da $5^{\text {a }}$ série participaram de um estudo dividido em 3 fases constituído de pré-teste, treinamento e pós-teste, resolução de situaçõesproblemas e entrevista individual.

$\begin{array}{ll}\text { A alternância } & 6 \text { alunos entre 7 } \\ \text { entre a } & \text { e } 8 \text { anos foram } \\ \text { interpretação } & \text { agrupados em } \\ \text { verbal e } & \text { tríades para } \\ \text { produção de } & \text { resolver, com } \\ \text { notações } & \text { estratégias } \\ \text { próprias pelo } & \text { próprias, } \\ \text { sujeito em } & \text { situações- } \\ \text { situações nas } & \text { problemas de } \\ \text { quais esteja } & \text { divisão } \\ \text { envolvida a } & \text { elementar por }\end{array}$

A maioria das tarefas eram de reprodução de técnicas e algoritmos, as instruções eram óbvias, sem ligação com o mundo real.

Há uma ligação entre a formação de conceitos e procedimentos. A construção de habilidades numéricas é gradual e intimamente ligada às experiências do dia a dia.

Quanto ao procedimento utilizado pelos alunos, houve um predomínio do aritmético no pré-teste e do algébrico no pós-teste.

Observou-se que tanto raciocínio como procedimento algébrico são apoiados na representação.

Inicialmente as concepções eram préaditivas, depois aditivas e elementares da divisão. A tomada de consciência se deu com a ação de dividir em 
217-226.

partição.

Examinar o
desempenho de
crianças em
situações de
divisão partitiva
ou por quotas,
utilizando como
resolução os
cálculos mentais.

Cálculos

mentais

(2004). A

resolução oral

de tarefas de

divisão por

crianças.

Estudos de

Psicologia, 9, 145-155.

divisão, ações e relações sujeito lógicoem uso,

Gaspar, M. F.
R. F. (2004)
Aprender a
contar, aprender
a pensar: As
sequências
numéricas de
contagem
abstrata
construídas por
crianças
portuguesas em
idade pré-
escolar. Análise
psicológica, 1,
119-1138. permitem um

partição,

propostas aumento nas oralmente em chances de sessões compreensão

Avaliar as sequências de contagem de crianças da educação infantil, analisar se os tipos de erros cometidos têm relação com a falta de clareza no nome dos números de dois dígitos na língua portuguesa. tomadas de consciência das aritméticas envolvidas.

requerem do dos invariantes matemáticos mostrando-se mais eficazes do que os algoritmos escritos, em algumas ocasiões.

gravadas em

vídeo e

transcritas.

Foram

observadas

todas as ações e

verbalizações

da criança e do

adulto,

participantes.

82 crianças do

Reino Unido

participaram de

entrevistas

individuais

com foco na

resolução de

situações

problema de

divisão

partitiva e

outras 80

participaram de

sessões que

tinham como

foco a

resolução de

problemas de

divisão por

cotas.

$\begin{array}{ll}\text { A dificuldade } & \text { 123 crianças } \\ \text { na } & \text { com idade } \\ \text { aprendizagem } & \text { média de } 5 \\ \text { da contagem de } & \text { anos e } 6 \text { meses } \\ \text { números de } & \text { realizaram uma } \\ \text { dois dígitos } & \text { prova onde } \\ \text { pode ser } & \text { deveriam } \\ \text { decorrente de } & \text { ensinar um } \\ \text { diferenças } & \text { boneco a } \\ \text { relativas a } & \text { contar. } \\ \text { irregularidade e } & \text { Repetiram essa } \\ \text { transparência } & \text { prova três } \\ \text { nos nomes dos } & \text { vezes. } \\ \text { números. } & \end{array}$

números. metades e

depois em mais

partes, em

seguida ocorreu

a estabilização

das ideias

aditiva de

divisão

chegando a de

divisão

elementar a

estabilidade do dividir.

As crianças apresentaram

dificuldade

quando houve aumento nos

valores do

divisor e

dividendo das

divisões, em

especial as

menores. As

crianças foram

capazes de

explicar os

procedimentos

utilizados na

resolução dos

cálculos

mentais,

quando foram solicitados.

As crianças

encontram

dificuldade em

aprender

sequência

numérica

convencional

onde há a

transição entre

uma dezena de

números e

outra e entre os

números

compreendidos entre 10 e 19 , decorrendo isso de

irregularidades linguísticas

para a

formação dos nomes. 


$\begin{array}{ll}\text { Moro, M. L. F. } & \text { Descrever a } \\ \text { (2004). } & \text { natureza e as } \\ \text { Notações da } & \text { transformações } \\ \text { Matemática } & \text { de notações em } \\ \text { infantil: Igualar } & \text { tarefas de } \\ \text { e repartir } & \text { igualização de } \\ \text { grandezas na } & \text { parcelas e } \\ \text { origem das } & \text { repartição, com a } \\ \text { estruturas } & \text { finalidade de } \\ \text { multiplicativas. } & \text { elaborar relações } \\ \text { Psicologia: } & \text { aditivas e } \\ \text { Reflexão e } & \text { multiplicativas e } \\ \text { crítica, 17, 251- } & \text { verificar o } \\ \text { 266. } & \text { significado das } \\ & \text { notações. }\end{array}$

Os professores
devem
considerar os
quantificadores
pessoais das
crianças para
poder
direcionar a
aprendizagem
para sistemas
matemáticos
formais.

foram agrupados em tríades para resolver tarefas propostas oralmente pelos pesquisadores.

Deviam resolvê-las por meio de material concreto, interpretar o que haviam feito e produzir notações a respeito da situaçãoproblema, suas verbalizações e dos adultos foram analisadas.

A utilização de resolução de situaçõesproblemas baseados na cultura do indivíduo coloca-se como uma alternativa à Matemática convencional.
12 alunos

\author{
As notações \\ dos alunos \\ eram \\ compostas de \\ desenhos, \\ algarismo e \\ escritas \\ alfabéticas, as \\ crianças foram \\ capazes de \\ lançar mão de \\ recursos que \\ possuíam em \\ seu repertório \\ para justificar o \\ que \\ assimilaram das \\ tarefas.
}

$\begin{array}{ll}\text { Alunos de 2 } & \text { Os sujeitos } \\ \text { turmas de EJA } & \text { faziam uso de } \\ \text { participaram de } & \text { estimativas e } \\ \text { um estudo } & \text { cálculos } \\ \text { etnográfico } & \text { mentais para } \\ \text { focado nos } & \text { resolver } \\ \text { conhecimentos } & \text { problemas da } \\ \text { matemáticos } & \text { vida diária, } \\ \text { utilizados no } & \text { eram capazes } \\ \text { cotidiano deles. } & \text { de realizar } \\ & \text { cálculos } \\ & \text { complexos mas } \\ & \text { erravam na } \\ & \text { escola. }\end{array}$

Nesta categoria, foi encontrado o maior número de artigos coletados. Trata-se de artigos teóricos e de relatos de pesquisa. Entre os trabalhos de cunho teórico, têm-se três referentes à revisão de literatura, um sobre divisão e números racionais, outro sobre a aquisição de habilidades numéricas, e o último sobre pesquisas relativas ao sentido de número. Os outros dois artigos teóricos referem-se às pesquisas atuais sobre o conceito de número e sobre o desenvolvimento cognitivo relacionado à aprendizagem matemática.

Os artigos desta categoria apresentam uma abordagem cujos três principais aspectos são: 1) o desenvolvimento de conceitos matemáticos iniciais; 2) as atividades de mediação 
para o desenvolvimento das competências matemáticas; e 3) as operações presentes no campo conceitual das estruturas multiplicativas. Quanto à metodologia utilizada nas pesquisas, houve a prevalência da abordagem qualitativa. Os principais instrumentos de coleta de dados foram: a observação, a entrevista, a produção de notações matemáticas e a resolução de situações-problemas.

Entre os principais procedimentos de análise de dados, destacamos a análise das produções escritas e verbais e a análise dos significados das ações durante as sessões de interação. Apenas dois estudos adotaram a metodologia quantitativa. Por essa razão, nestes últimos, houve o predomínio da aplicação de testes, da análise de documentos e da análise estatística de dados.

Entre as abordagens teóricas adotadas pelos trabalhos pertencentes a esta terceira categoria, encontramos diversas referências aos estudos da Psicologia da Educação Matemática. Os trabalhos que se fundamentaram nessa perspectiva visaram, principalmente, ao estudo dos processos de construção dos conceitos matemáticos.

Entre os principais autores que foram utilizados para a fundamentação dos estudos analisados, estão: Piaget e Szeminska (1971), Piaget (1978), Vergnaud (1990) e Nunes e Bryant (1996). Apenas dois artigos desta categoria não adotaram essa mesma corrente teórica e se basearam nos estudos da abordagem experimental do comportamento e na equivalência de estímulos, focando, prioritariamente, o treino de habilidades numéricas e algoritmos.

Entre os artigos que discutem as primeiras aquisições matemáticas, as discussões concentram-se no conceito e no sentido de número e no desenvolvimento cognitivo da aprendizagem matemática (Senna, Dornelles \& Yunnes, 2013; Cruz, 2013; Nogueira, 2011; Barbosa, 2007). Esses artigos apontam que as primeiras aquisições matemáticas são fundamentais para a construção do pensamento matemático de alto nível. Os autores 
salientam que essa construção implica um longo e lento processo de construções constantes, que se apoiam no contexto no qual o indivíduo está inserido. Cruz (2013) pontua que o pensamento se desenvolve a partir da manipulação do concreto em busca da compreensão conceitual.

Os artigos dessa categoria sugerem diversas formas de mediação do conhecimento para que os alunos possam realizar a compreensão conceitual. Entre elas, destacam-se: 1) possibilitar aos alunos conhecer e manipular situações-problemas de natureza e classificações diversas (Mendonça et al., 2007), como, por exemplo, os problemas de medidas (aqueles que envolvem o pensamento combinatório); segundo Placha e Moro (2007), esses problemas são trabalhados com uma pequena frequência, nas salas de aula das escolas; 2) valorizar as notações elaboradas pelos alunos, nas resoluções matemáticas e também as diversas estratégias utilizadas por eles, no seu dia a dia, como arredondamentos, estimativas e cálculos mentais; de forma que, a partir dessas notações e estratégias, os alunos possam construir o entendimento da Matemática formal utilizada na escola (Moro, 2004; Fantinato, 2004); 3) utilizar materiais concretos como suporte para o ensino da Matemática, de forma que representem, coerentemente, a realidade que se pretende reproduzir, evitando, assim, equívocos conceituais para os estudantes (Batista \& Spinillo, 2008).

Outro ponto apresentado pelos artigos desta terceira categoria diz respeito às operações presentes no campo conceitual das estruturas multiplicativas. Moro (2009) descreve que esse campo envolve situações-problemas que requerem, para sua solução, tanto as operações de multiplicação como as de divisão. Uma das principais conclusões desses artigos refere-se ao fato de que situações de divisão por partição se apresentam menos complexas para o entendimento das crianças do que as de divisão por cota. Além disso, observou-se que, em geral, os estudantes que se utilizam de estratégias não 
convencionais de cálculo demonstram melhor compreensão dos conceitos da divisão do que aqueles que utilizam apenas algoritmos formalizados (Fávero \& Pina Neves, 2012; Coelho, 2008; Moro, 2004; Moro, 2005).

A categoria apresenta dois consensos principais. O primeiro deles se relaciona ao uso, pelos alunos, de notações próprias (letras, desenhos, algarismos) e estratégias pessoais de cálculo (arredondamentos, estimativas, cálculos mentais) para a resolução de atividades propostas. Os autores argumentam que considerar o uso dessas notações e estratégias não significa excluir o ensino da Matemática formalizada. A proposição feita refere-se justamente ao contrário. Utilizar essas notações como ponto de partida para que os alunos compreendam e tomem consciência da lógica dos conceitos matemáticos convencionais (Fantinato, 2004; Fávero \& Pina Neves, 2012; Moro, 2009).

O segundo consenso está relacionado ao primeiro e enfatiza a necessidade da compreensão conceitual da Matemática. Em geral, os autores dessa categoria apontam para a necessidade de os alunos manipularem os objetos e os conceitos matemáticos, de forma consciente. Sendo assim, censuram práticas de ensino que enfatizem apenas o uso exclusivo de algoritmos formalizados e de fórmulas matemáticas, sem a devida reflexão. Em outras palavras, eles não aprovam o ensino que privilegie atividades repetitivas, em que o papel do aluno seja agir de forma mecânica (Fávero \& Pina Neves, 2012). 


\subsubsection{A quarta categoria de artigos: Matemática e formação de professores e outros}

\section{profissionais da educação}

Tabela 4 -Artigos sobre formação de professores e outros profissionais da educação.

\begin{tabular}{|c|c|c|c|c|c|}
\hline$\overline{N^{0}}$ & $\begin{array}{l}\text { Referência } \\
\text { completa }\end{array}$ & Objetivos & Tese & Método & $\begin{array}{l}\text { Resultados } \\
\text { descritos }\end{array}$ \\
\hline 1 & $\begin{array}{l}\text { Almouloud, S. A., } \\
\text { Manrique, A. L., } \\
\text { Silva, M. J. F., \& } \\
\text { Campos, T. M. M. } \\
\text { (2004). A } \\
\text { geometria no } \\
\text { ensino } \\
\text { fundamental: } \\
\text { reflexões sobre } \\
\text { uma experiência } \\
\text { de formação } \\
\text { envolvendo } \\
\text { professores e } \\
\text { alunos. Revista } \\
\text { Brasileira de } \\
\text { Educação, 27, 94- } \\
\text { 108. }\end{array}$ & $\begin{array}{l}\text { Apresentar os } \\
\text { principais } \\
\text { resultados de um } \\
\text { projeto de } \\
\text { pesquisa sobre a } \\
\text { aprendizagem de } \\
\text { geometria e as } \\
\text { representações dos } \\
\text { professores das } \\
\text { séries finais do } \\
\text { ensino } \\
\text { fundamental. }\end{array}$ & $\begin{array}{l}\text { A geometria é } \\
\text { considerada como } \\
\text { um tópico } \\
\text { importante para a } \\
\text { aprendizagem dos } \\
\text { alunos, mas por } \\
\text { não haver } \\
\text { planejamento } \\
\text { adequado de } \\
\text { atividades que a } \\
\text { envolva, os alunos } \\
\text { acabam por não } \\
\text { construírem os } \\
\text { conceitos, ligados } \\
\text { a ela, } \\
\text { adequadamente. }\end{array}$ & $\begin{array}{l}\text { Professores do } \\
\text { ensino } \\
\text { fundamental } \\
\text { participaram de } \\
\text { encontros } \\
\text { semanais nos } \\
\text { quais refletiam } \\
\text { sobre a } \\
\text { geometria. } \\
\text { Manipulavam } \\
\text { materiais } \\
\text { concretos, } \\
\text { utilizavam } \\
\text { instrumentos de } \\
\text { desenhos e } \\
\text { construíam } \\
\text { novos materiais } \\
\text { e aplicaram } \\
\text { sequências } \\
\text { didáticas em } \\
\text { suas turmas }\end{array}$ & $\begin{array}{l}\text { A geometria tem } \\
\text { sido deixada de } \\
\text { lado nas escolas, } \\
\text { os cursos de } \\
\text { formação e } \\
\text { capacitação não } \\
\text { estão } \\
\text { proporcionando } \\
\text { aos professores a } \\
\text { fundamentação } \\
\text { adequada para } \\
\text { trabalhar a } \\
\text { geometria e os } \\
\text { livros didáticos } \\
\text { não possibilitam } \\
\text { uma compreensão } \\
\text { adequada dos } \\
\text { conceitos } \\
\text { geométricos. }\end{array}$ \\
\hline 2 & $\begin{array}{l}\text { Freitas, M. T. M., } \\
\text { \& Fiorentini, D. } \\
\text { (2008). Desafios e } \\
\text { potencialidades da } \\
\text { escrita na } \\
\text { formação docente } \\
\text { em Matemática. } \\
\text { Revista Brasileira } \\
\text { de Educação, 13, } \\
\text { 138-149. }\end{array}$ & $\begin{array}{l}\text { Compreender as } \\
\text { potencialidades } \\
\text { formativas da } \\
\text { utilização de } \\
\text { modos diversos de } \\
\text { comunicação, em } \\
\text { especial a escrita, } \\
\text { em um curso de } \\
\text { licenciatura de } \\
\text { Matemática. }\end{array}$ & $\begin{array}{l}\text { Explorar a leitura } \\
\text { e a escrita, no } \\
\text { processo de } \\
\text { ensinar e aprender } \\
\text { Matemática, na } \\
\text { licenciatura, como } \\
\text { uma forma } \\
\text { potencial que } \\
\text { amplia o poder de } \\
\text { compreensão e } \\
\text { reflexão sobre a } \\
\text { Matemática. }\end{array}$ & $\begin{array}{l}4 \text { alunos do } \\
\text { curso de } \\
\text { Matemática } \\
\text { contaram suas } \\
\text { histórias em } \\
\text { diferentes } \\
\text { momentos. } \\
\text { Participaram de } \\
\text { entrevistas, } \\
\text { elaboraram } \\
\text { autobiografias e } \\
\text { participaram de } \\
\text { conversas. }\end{array}$ & $\begin{array}{l}\text { A organização } \\
\text { escrita dos } \\
\text { pensamentos } \\
\text { permitiu aos } \\
\text { futuros professores } \\
\text { de Matemática } \\
\text { identificar } \\
\text { conhecimentos } \\
\text { considerados como } \\
\text { tácitos, } \\
\text { problematizando e } \\
\text { (re) significando- } \\
\text { os. }\end{array}$ \\
\hline 3 & $\begin{array}{l}\text { Ferreira, E. B., } \\
\text { Soares, A. B., \& } \\
\text { Lima, J. C. (2008). } \\
\text { O resgate das } \\
\text { demonstrações: } \\
\text { uma contribuição } \\
\text { da Informática à } \\
\text { formação do } \\
\text { professor de } \\
\text { Matemática. } \\
\text { Revista Semestral } \\
\text { da Associação } \\
\text { Brasileira de } \\
\text { Psicologia Escolar }\end{array}$ & $\begin{array}{l}\text { Utilizar ambiente } \\
\text { de geometria } \\
\text { dinâmica no } \\
\text { processo de } \\
\text { ensino e } \\
\text { aprendizagem de } \\
\text { Geometria para } \\
\text { estimular níveis } \\
\text { de pensamento } \\
\text { geométrico com } \\
\text { desenvolvimento } \\
\text { do raciocínio } \\
\text { lógico dedutivo de }\end{array}$ & $\begin{array}{l}\text { Recursos de } \\
\text { tecnologia da } \\
\text { informação, como } \\
\text { por exemplo, o } \\
\text { ambiente de } \\
\text { geometria } \\
\text { dinâmica (GD), } \\
\text { tem provocado } \\
\text { uma verdadeira } \\
\text { revolução no } \\
\text { ensino da } \\
\text { educação } \\
\text { matemática. }\end{array}$ & $\begin{array}{l}8 \text { professores de } \\
\text { Matemática } \\
\text { responderam a } \\
\text { questionários de } \\
\text { sondagem } \\
\text { elaboraram } \\
\text { algumas } \\
\text { produções na } \\
\text { forma de } \\
\text { material escrito, } \\
\text { registro das } \\
\text { manifestações } \\
\text { dos professores } \\
\text { durante a }\end{array}$ & $\begin{array}{l}\text { Utilizar ambientes } \\
\text { de Geometria } \\
\text { dinâmica na } \\
\text { formação de } \\
\text { professores } \\
\text { contribui para a } \\
\text { reflexão sobre a } \\
\text { prática pedagógica } \\
\text { de professores. }\end{array}$ \\
\hline
\end{tabular}


e Educacional

docentes

(ABRAPEE), 12, 381-389.

Lima, C. N. M. F.,
\& Nacarato, A. M. (2009). A investigação da própria prática: Mobilização e apropriação de saberes profissionais em Matemática.

Educação em revista, 25, 241266.

Fávero, M. H., \& Pina Neves, R. S. (2013). A docência universitária como lócus de pesquisa do desenvolvimento adulto. Revista Semestral da Associação Brasileira de Psicologia Escolar e Educacional, 17, 319-328.

6 Magina, S. A. (2011). A pesquisa na sala de aula de Matemática das séries iniciais do Ensino Fundamental. Contribuições teóricas da psicologia. Educar em Revista, n. esp., 63-75.
Analisar os saberes mobilizados por uma professora pesquisadora durante uma investigação de sua própria prática em Matemática.

Capacitar os alunos do curso de especialização em psicopedagogia, a intervir na mediação do conhecimento matemático junto a alunos e professores.

Abordar o tema da educação

Matemática discutindo uma pesquisa realizada em uma sala de aula do Ensino Fundamental.

\section{Descrever uma} pesquisa sobre a construção de conceitos numéricos em crianças entre $2 \mathrm{e}$ 5 anos da educação infantil. realidade, 38, 227 (ucaço infantil uma pesquisa etnográfica. Educação e 248. \& Yunes, M. A. M. (2013).

Conceitos numéricos na Ribeiro, M. R. (2011).
Apresentar exemplos de
Há uma pluralidade no que diz respeito à formação inicial dos pesquisadores em Matemática. Isso gera diferentes tipos de abordagens nas pesquisas de educação matemática.
A pesquisa sobre a aponta para um novo modelo de formação professor é protagonista do seu profissional. docente possui uma teoria por trás dela. construir uma prática a partir da dados obtidos dos alunos. própria prática desenvolvimento

Qualquer prática

discussão de

textos.

Uma professora realizou uma pesquisa numa turma de alunos do $1^{\circ}$ ano do Ensino médio, desenvolveu tarefas exploratórioinvestigativas junto a seus próprios alunos.

36 alunos de um curso de especialização participaram de um procedimento didático com um total de trinta horas distribuídas em 8 encontros com quatro horas cada.

103 professores do Ensino Fundamental foram solicitados a elaborar e resolveram 8 situações de problemas, de maneira que 4 fossem de estrutura aditiva e 4 de estrutura multiplicativa.

A Educação Infantil Pesquisa propicia situações etnográfica de construção do desenvolvida em conhecimento matemático, por duas escolas. Os instrumentos de parte das crianças, coleta utilizados mas que nem sempre são valorizadas pelos professores. foram: entrevista, observação, análise de documentos.

As mediações da professorapesquisadora no decorrer da pesquisa geraram avanços na mobilização de conhecimentos matemáticos por parte dos alunos.

Houve uma reelaboração da ideia da Matemática como uma disciplina difícil, assim que os sujeitos foram tomando consciência dos conceitos, durante as resoluções de situaçõesproblemas.

A maioria dos problemas elaborados pelos professores era somente de natureza aditiva. Os raciocínios exigidos nos problemas eram de dois tipos: composição ou situações de transformação.

Professores da pesquisa não valorizaram a produção espontânea das crianças o que sugeriu a necessidade de mudanças na formação de professores.

Os alunos Apresenta necessitam adquirir reflexões
Se forem utilizadas 


\begin{abstract}
Abordagem aos números decimais e suas operações: a importância de uma eficaz. navegação entre representações. Educação e

tarefas relativas a multiplicação de decimais e discutir o conhecimento matemático a respeito da aplicação dessas tarefas.
\end{abstract} Pesquisa, 37, 407422.

9 Groenwald, C. L. O., \& Nunes, G. S. (2007). Currículo de Matemática no ensino básico: a importância do desenvolvimento dos pensamentos de alto nível Relime, 10, 97116. Grando,

R. C.,

Nacarato, A. M., \& Gonçalves, L. M. (2008) Compartilhando saberes em geometria. Caderno Cedes, 28, 39-56.

11 Vieira, G. A., \& Zaidan, S. (2013).

Sobre o conceito de prática pedagógica e o professor de Matemática. Paidéia, 14, 33-54.
Apresentar reflexões sobre o processo de ensino e aprendizagem da Matemática para desenvolvimento do pensamento de alto nível. para a promoção um claro

entendimento, no

Ensino

Fundamental, da compreensão do sistema de posição e a relação com algoritmos das quatro operações.

No ensino da
Matemática as
atividades devem
promover o
pensamento
abstrato e
raciocínio de alto
nível.
nível.
A geometria está ausente da maioria das salas de aula. Alunos chegam ao ensino superior com um conhecimento restrito da geometria. Francisco $\mathrm{SP})$.

Oferecer subsídios da análise da prática pedagógica do professor de Matemática.
A prática de ensino é permeada de inúmeras variáveis que influenciam as ações dos professores.

\section{Aplicação de uma tarefa exploratória investigativa a alunos da $7^{\mathrm{a}}$ série. Os relatos da professora e os registros dos alunos foram analisados pelos integrantes do grupo da universidade.}

Revisão de literatura focada na: definição de prática pedagógica na visão dialética, histórico da educação brasileira e trabalho docente na Matemática e inclusão social. múltiplas representações numa tarefa, será permitida ao aluno a compreensão da sua ação e não somente a aplicação de uma regra.

Alunos

apresentaram dificuldades para associar seus conhecimentos prévios nas resoluções matemáticas. Em suas respostas observou-se o predomínio de raciocínios matemáticos elementares.

Considerou-se importante valorizar os conhecimentos dos alunos, enfatizando a possibilidade de se dar voz a explicação deles, sobre a própria produção, na sala de aula.

Necessidade de mudanças na formação inicial e continuada do professor para que possa desenvolver um trabalho como agente de transformação social. 
A quarta categoria refere-se a artigos relativos à formação inicial e continuada de professores e outros profissionais da educação, em relação à Matemática. Do conjunto de 11 artigos, dois eram artigos teóricos e nove constituíam relatos de pesquisas empíricas. Os artigos teóricos abordaram dois aspectos, a saber: a prática pedagógica do professor de Matemática e o ensino de números decimais. Já os artigos relativos às pesquisas empíricas abordaram o ensino da geometria, a formação docente, a compreensão de conceitos matemáticos e o uso da escrita como estratégia para a formação de professores.

Entre os sujeitos participantes das pesquisas, identificamos que $77,7 \%$ já possuíam o curso superior e que apenas $22,2 \%$ eram estudantes de cursos de licenciatura em Matemática. Com relação às metodologias adotadas nas pesquisas, identificamos que há a prevalência da pesquisa qualitativa. Os principais instrumentos de coleta de dados utilizados foram: questionários, proposição e resolução de situações-problemas, registros, notações matemáticas e narrativas. Os procedimentos de análise de dados, de modo geral, visaram à análise das estratégias de resolução de problemas e a análise das representações e concepções dos professores.

As principais referências, presentes nos artigos analisados, foram os trabalhos de Duval (1995) e Brousseau (1986). Esta categoria apresentou a discussão de três aspectos principais: 1) a formação inicial e continuada de professores, 2) a compreensão conceitual dos docentes, e 3) as pesquisas de intervenção e de investigação da própria prática.

Entre os artigos que se referiam à formação inicial e continuada de professores de Matemática, defendeu-se que é por meio da formação que o professor aperfeiçoa a competência técnica para desenvolver as ações mentais dos alunos, de modo que possam construir a compreensão de conceitos. De acordo com os autores, os cursos de formação continuada podem oferecer transformações significativas nos níveis de pensamento e de raciocínio lógico-dedutivo dos professores. Eles consideram esses espaços como 
fundamentais para o enriquecimento profissional, pois promovem mudanças coletivas a partir de modificações nas concepções dos docentes. Modificações, que segundo eles, reverberam em uma prática de ensino mais significativa para alunos e professores (Almouloud, Manrique, de Silva \& Campos, 2004; Ferreira, Soares \& Lima, 2008; Grando, Nacarato \& Gonçalves, 2008).

Os artigos que discutem a compreensão de conceitos como fator central da formação (Ribeiro, 2011; Vieira \& Zaidan, 2013) apresentam a defesa de que os professores devam ter um conhecimento matemático sólido. Com isso, os docentes saberão mobilizar as diferentes formas de representações para o ensino, que resultarão em uma melhor compreensão dos objetos da Matemática, por parte dos alunos. Além disso, eles também afirmam que os professores saberão escolher, entre os diversos materiais manipuláveis e situações do cotidiano, aqueles que auxiliarão os seus alunos em suas construções de significados matemáticos (Ribeiro, 2011; Vieira \& Zaidan, 2013).

No último aspecto apontado pelos artigos, é realizada a discussão sobre as pesquisas da prática didática e as pesquisas de intervenção. A pesquisa da prática didática é apresentada por Lima e Nacarato (2009), que defendem essa modalidade de pesquisa como um instrumento que permite aos docentes tornarem público os saberes mobilizados em suas práticas de sala de aula. Segundo os autores, essas pesquisas favorecem os processos de reflexão, os conflitos e também as transformações a respeito da própria atuação docente, o que auxilia na compreensão de conceitos mediados, por eles, na sala de aula. Fávero (2011), por sua vez, defende a pesquisa de intervenção como um método apropriado para o desenvolvimento de novas competências de docentes e alunos. A autora afirma que, nesse contexto, o professor reflete sobre sua forma de avaliar, o que favorece a percepção de que a avaliação não se resume a aferição de erros e acertos, mas auxilia a compreendê-la como um processo que subsidia a prática de sala de aula. 
Desse modo, a partir da análise dos artigos listados nesta quarta categoria, pode-se concluir como principal consenso a importância da formação docente para a mediação significativa dos conceitos matemáticos. Tal formação é tida como indispensável independentemente de sua modalidade, seja ela inicial, continuada ou aquela que ocorre por meio do desenvolvimento de uma pesquisa.

\subsubsection{Discussão geral das categorias e conclusões}

A análise das quatro categorias de artigos nos permitiu identificar que elas possuem alguns pontos em comum. Primeiramente, pode-se destacar a relação que há entre as metodologias utilizadas. Na maioria dos artigos, identificamos que a metodologia de maior ocorrência é a da pesquisa qualitativa. Entre os principais instrumentos de coleta de dados, destacaram-se a aplicação de questionários, a resolução de situações-problemas e a produção de notações. No que concerne à análise de dados, as principais formas utilizadas pelos pesquisadores cujos artigos analisamos foram: a interpretação dos significados das notações dos alunos, a interpretação das narrativas e/ou concepções e as representações dos docentes.

Entre os principais autores referidos, no conjunto dos artigos que foram listados nas quatro categorias, identificamos Vergnaud (1991), Nunes e Bryant (1997). Apesar de vários artigos se referirem à produção de notações matemáticas ou à importância dos registros nas resoluções de situação-problemas e para a construção de conceitos, poucos trabalhos se basearam, por exemplo, nos estudos sobre os registros de representação semiótica de Duval (1995). Quanto aos participantes das pesquisas, as crianças foram consideradas como sujeitos, apenas nos estudos relativos ao desenvolvimento de competências matemáticas (categorias 2 e 3). Adolescentes, por sua vez, estiveram presentes, como participantes, em três categorias (categorias 1, 2 e 3). Na categoria 4, que 
teve como participantes apenas adultos, observamos que somente um estudo se reportou aos professores da educação infantil, todos os outros mencionaram pesquisas com professores de adolescentes (Séries Finais do Ensino Fundamental e Ensino Médio).

Evidenciamos um escasso interesse quanto ao desenvolvimento de competências matemáticas de sujeitos adultos. Os estudos, em geral, apontaram a aprendizagem do adulto na Matemática voltada para a formação docente. No conjunto das categorias analisadas, apenas um estudo abordou a aprendizagem da Matemática por jovens e adultos: o de Fávero e Pimenta (2006). Os demais eram estudos que foram realizados com professores, sem referência à psicologia do desenvolvimento adulto, com exceção do estudo de Fávero (2011). Sendo assim, os dados coletados nesta revisão de artigos nos permitem concluir que o interesse dos pesquisadores prevaleceu sobre os processos e fatores que influenciam a aprendizagem de adolescentes.

A revisão realizada nos permitiu identificar dois aspectos recorrentes, entre as categorias de artigos, que vêm ao encontro do que defendemos nesta dissertação. O primeiro deles se refere a estimular os alunos para o uso de notações pessoais de cálculo nas resoluções matemáticas; e o segundo é à importância da intervenção docente no processo de desenvolvimento das elaborações conceituais dos estudantes.

Como já afirmado na introdução deste trabalho, muitas vezes, as escolas negligenciam o uso de notações e dos procedimentos pessoais de cálculo utilizados pelos alunos nas resoluções da Matemática escolar. Os artigos desta revisão, principalmente aqueles da categoria 3, defendem a pertinência do uso desses procedimentos no ensino, pois os consideram relevantes para o desenvolvimento da compreensão dos conceitos matemáticos. Assim, eles sugerem uma prática que vai além de um ensino que prioriza apenas o uso de regras e algoritmos padronizados (ver, por exemplo, Fávero \& Pina Neves, 2012). 
Fávero $(2009 b, 2014)$ afirma que ensinar utilizando apenas regras, sem considerar os campos conceituais, implica ignorar a relação que existe entre o ensino formalizado e o desenvolvimento psicológico dos indivíduos. Para essa autora, a formalização do conhecimento é um instrumento que possibilita o desenvolvimento do pensamento crítico e reflexivo. Desse modo, quando os autores dos artigos defendem o uso de formas alternativas de cálculo, não significa que estejam sugerindo a desconsideração da Matemática formalizada. Na verdade, espera-se que, a partir dos procedimentos elaborados pelos próprios estudantes, eles possam desencadear o processo de tomada de consciência da lógica formal da Matemática (Fávero, 2009b, 2011, 2012).

Compatível com essa ideia, há a questão de que um dos pontos importantes no ensino e na intervenção junto às dificuldades apresentadas em relação à Matemática seja o incentivo à compreensão do significado das notações matemáticas. No estudo de Fávero e Soares (2002), afirma-se que a aquisição da competência do uso da notação matemática é um processo complexo, mas que, uma vez desenvolvido, ele torna-se um importante ponto para o desenvolvimento dos indivíduos. As autoras afirmam que um dos problemas relacionados à aprendizagem da Matemática escolar está justamente no fato de

a escola não trabalhar com a possibilidade do sujeito formar representações identificáveis; a escola ignora isto, e o sujeito acaba sobrepondo representações. Ou seja, não lhe é facultado um tratamento dos dados que ele dispõe; há uma imposição de regras: “tem que ser assim.” (Fávero \& Soares, 2002, p. 48)

Duval (2013) explica que tanto os fracassos como os bloqueios, enfrentados pelos alunos na aprendizagem da Matemática, se evidenciam principalmente quando se solicita ao sujeito a mudança de um registro ao outro. Outra dificuldade se apresenta quando a solicitação se refere à mobilização de dois registros ao mesmo tempo. Esse autor afirma que os alunos vivenciam, no processo escolar, o que ele chama de "enclausuramento do 
registro”. Em outras palavras, isso significa que há a utilização de apenas uma forma de registro, o que, segundo ele, limita a capacidade de compreensão de novos conceitos matemáticos. Por esse motivo, ele entende que "a compreensão da Matemática implica a capacidade de mudar de registro" (Duval, 2013, p. 21).

Outro aspecto identificado nesta revisão é aquele referente à relação existente entre a formação docente e as elaborações conceituais de estudantes. Os artigos apontam que, em geral, um professor que compreende os conceitos matemáticos é mais propenso a desenvolver compreensões conceituais em seus alunos. Esses mesmos artigos indicam, ainda, que essa compreensão conceitual, por parte dos professores, está ligada às aquisições realizadas por eles no seu processo de formação profissional.

No entanto, Muniz (2009) argumenta em defesa da mediação do conhecimento, a ser realizada pelo professor. Segundo ele, o docente deve estar atento aos esquemas dos alunos nas resoluções matemáticas, identificando "os conhecimentos em ação, as potencialidades, as incompletudes, os desvios, os atalhos, as ressignificações, os erros e os obstáculos" que os estudantes enfrentam em relação aos conceitos (Muniz, 2009, p. 115). Ao agir dessa forma, o docente torna-se mais consciente para definir as teorias e metodologias às quais se filiará para motivar os alunos na construção do conhecimento formal da Matemática. Muniz (2009) afirma, também, que assumir essa proposta implica um novo formato de interação entre alunos e docentes que requer a escuta do aluno. Ou seja, é fundamental preocupar-se com o que o aluno tem a dizer a respeito de suas próprias resoluções na sala de aula.

Além desses temas que acabamos de destacar, entre as categorias identificamos outros dois pontos importantes de serem retomados nesta discussão geral. O primeiro deles diz respeito à relação entre desempenho matemático e gênero; e o segundo, à relação entre afetividade e aprendizagem. Quanto à relação entre Matemática e gênero, evidenciamos, 
tal como salientado por Fávero (2010), que alguns artigos ainda relacionam a Matemática à razão e ao homem, supondo maior facilidade do sexo masculino na compreensão da Matemática e uma possível dificuldade das mulheres. A permanência dessas ideias conservadoras pode explicar porque, apesar do bom desempenho, as mulheres ainda são minoria nos cursos relacionados a Matemática e tecnologia, como as engenharias e informática.

No que se refere à questão entre afetividade e desempenho na Matemática, em geral, a ideia veiculada por esses artigos é a de que a afetividade influencia o sucesso ou o fracasso na Matemática escolar. Nesse caso, no entanto, não podemos perder de vista, assim como nos diz Fávero (2005, 2007, 2009, 2014), a articulação dos valores sociais e das estratégias cognitivas envolvidas no contexto de aquisição do conhecimento. De acordo com a autora, isso nos permitirá considerar a relação entre cidadania e conhecimento nas situações de ensino. Dessa forma, poderemos problematizar a desigualdade de participação de homens e mulheres nas diversas áreas de conhecimento, como evidenciado no aspecto anterior.

Ao considerarmos essas relações, podemos propiciar um contexto no qual os professores tenham uma visão crítica dos valores que medeiam na sala de aula e da forma como isso interfere na aprendizagem dos alunos (Fávero, 2014). Em outras palavras, aos docentes é necessário sair da superficialidade dos aspectos visíveis a olho nu, e adentrar as regulações internas do indivíduo, como se referia Vygotsky (1989), que são engendradas pela mediação de signos externos, presentes no mundo social.

A abordagem de Fávero (2014) pode ser articulada com a de Osti e Brenelli (2013), quando apontam que a aprendizagem se caracteriza pela relação entre as competências dos alunos e as interações que estabelecem na sala de aula. Segundo essas autoras, a cada ação dos sujeitos, durante a aprendizagem, são mobilizados tanto afetos como conhecimentos. 
Essa posição nos reporta a Piaget (1964), que discorreu sobre a importância da afetividade no processo de aprendizagem, mas sem excluir a inteligência desse processo. Isso porque, para ele

a afetividade não é nada sem a inteligência, que lhe fornece meios e esclarece fins. É pensamento pouco sumário e mitológico atribuir as causas do desenvolvimento às grandes tendências ancestrais, como se as atividades e o crescimento biológico fossem por natureza estranhos à razão. Na realidade, a tendência mais profunda de toda atividade humana é a marcha para o equilíbrio. E a razão - que exprime as formas superiores deste equilíbrio - reúne nela a inteligência e a afetividade. (Piaget, 1964, p. 65)

A análise de Damiani (2006) é compatível com essa discussão realizada por Piaget. Segundo a autora, pesquisas que consideram apenas os fatores familiares e os da vida pessoal dos estudantes, para explicar o seu desempenho escolar, são limitadas. Assim, podemos dizer que tanto fatores emocionais como cognitivos influenciam o desempenho escolar dos alunos como referido na análise acima, a partir de Fávero (2014).

Ao final dessa discussão, podemos dizer que, entre as publicações analisadas, há um consenso geral em torno da necessidade de mudança das práticas de ensino da Matemática. Vimos que elas sugerem a substituição da ênfase na resolução de algoritmos e na aplicação de regras mecanizadas, por uma manipulação de conceitos matemáticos envolvendo a reflexão a respeito de seus processos de construção. Essa é uma forma de lidar tanto com a aprendizagem e como com a compreensão dos estudantes (ver, por exemplo, Fávero, 2011; Fávero \& Pina Neves, 2011).

Além do mais, podemos dizer que evidenciamos, após estas análises, uma escassez significativa de pesquisas metodológicas de intervenção com alunos que apresentam baixo desempenho escolar. Salientamos que o desenvolvimento de pesquisas como essas poderiam demonstrar a natureza do desempenho dos estudantes e fundamentar projetos de 
intervenção mais amplos, com a participação de professores e outros profissionais que atuam nas séries iniciais da escolarização.

É nesse sentido que acreditamos na pertinência da proposta de Fávero (2000, 2001, 2005, 2007, 2009a, 2009b, 2011), pois essa abordagem não visa somente à identificação das dificuldades dos sujeitos, mas o seu processo de desenvolvimento, por meio da articulação entre pesquisa e intervenção. A autora propõe a investigação a respeito das aquisições de conceitos considerando a produção do sujeito, além da relação entre competências e dificuldades. Isso permite situar todo caso de forma individual, além de possibilitar a análise dos processos mediacionais ocorridos na interação interpessoal, o que inclui o tipo de material utilizado e a natureza das atividades propostas (Fávero, 2003). Salientamos que essa proposta será apresentada em detalhes na segunda parte desta dissertação.

A sequência do texto abordará a importância do conceito de número para as aquisições matemáticas. A ênfase se dará em torno da discussão da importância das aquisições matemáticas iniciais como fundamento de aprendizagens matemáticas de maior complexidade. 


\subsection{A Importância do Conceito de Número}

Em um relato de intervenção com uma criança com Síndrome de Down, Fávero e Oliveira (2004) apresentam vários estudos sobre a aquisição do conceito de número, partindo daquele de Piaget e Szeminska (1975). As autoras enfatizam a tese de Piaget de que "a noção numérica é uma construção primária da criança” (Fávero \& Oliveira, 2004, p. 71). Outro importante estudo citado é o de Bryant (1995), pesquisador que também ressalta duas importantes conclusões dos estudos de Piaget e Szeminska (1975):

a primeira é que a criança não tem, a princípio, a compreensão da propriedade de cardinalidade do número; a segunda é que uma criança que conta os cinco elementos de dois conjuntos, e, apesar dessa contagem, diz que aquele no qual a distância entre os elementos é visualmente maior, tem mais elementos, não tem de fato a compreensão do significado da palavra "cinco". (Fávero \& Oliveira, 2004, p. 71)

As autoras retomam, ainda, Gelman e Gallistel (1978), os quais apresentam dois tipos de habilidades numéricas no desenvolvimento do conceito de número na criança pequena. A primeira delas é a capacidade de abstração numérica, que consiste em representar uma quantidade em um conjunto, contá-la e compreender que a finalização dessa contagem totaliza o conjunto. A segunda refere-se à capacidade de raciocínio numérico, na qual, ao operar com um conjunto, o indivíduo tem a noção de que a disposição dos seus elementos não altera a sua quantidade, mas que acrescentar ou tirar elementos o transforma.

Para salientar a complexidade da aquisição do conceito de número, Fávero e Oliveira (2004) retomam o trabalho de Vergnaud (1986). Segundo o autor, este é um conceito cujo fundamento se encontra em outros conceitos associados e hierarquizados, como a cardinalização e a inclusão. Foi baseado na ideia da relação e da hierarquização entre conceitos que Vergnaud (1990) propôs a Teoria dos Campos Conceituais. 
Essa teoria implica a consideração de que um conceito não pode se desenvolver de forma isolada. Para Vergnaud (2007), o conceito é composto por um trio de conjuntos que formam um sistema. Entre esses conjuntos, estão: as situações, os invariantes operatórios e as formas linguísticas e simbólicas (representações). Esse trio de conjuntos pode ser definido, como afirma Muniz (2009), pela função C (S, I, R), ou seja: Conceito (Situação, Invariantes Operatórios, Representação). Nessa função, as situações referem-se ao contexto no qual os conceitos emergem; os invariantes aos objetos, propriedades e relações matemáticas; e as representações, aos diagramas, sentenças e gráficos (Muniz, 2009).

Nessa teoria, o elemento central é o esquema - estrutura responsável pela organização da ação do indivíduo - que se trata da mobilização de conceitos disponíveis no repertório cognitivo em uma dada situação (Muniz, 2009). Um exemplo de um importante esquema para a construção do conceito de número é o da enumeração. Vergnaud (2009a) explica que é possível identificar pelo menos dois conceitos de Matemática implícitos no esquema da enumeração: o conceito de correspondência biunívoca e o número cardinal.

A análise de Vergnaud (1991, 2009a) se articula com os estudos sobre o sentido de número. O sentido de número é descrito como a capacidade dos indivíduos de compreender os números, suas operações e suas relações (Yang, Li \& Li, 2008). Para esses autores, o desenvolvimento do sentido de número possibilita aos indivíduos o uso consciente e eficiente de várias estratégias de cálculo e raciocínio matemático. Dessa forma, esses autores afirmam que o indivíduo se torna competente na resolução de situações cotidianas envolvendo o conhecimento matemático (Yang, Li \& Li, 2008). Desse modo, por meio da compreensão do sentido de número, as crianças são capazes de alcançar o entendimento das relações matemáticas (Corona, 2010). Segundo esse autor, a resolução de tarefas não pode se calcar apenas na aplicação daquilo que ele chama de receitas 
mecanizadas, isto é, regras e algoritmos. Para ele, desenvolver o sentido de número vai muito além da memorização de regras matemáticas e a sua aplicação em algoritmos.

Essa afirmação é compatível com a proposta de Parker (2008), o qual defende que para se ter competência matemática, é preciso entender as relações numéricas assim como analisa Fávero (2009a, 2009b). Esse entendimento das relações numéricas vai ao encontro das ideias de Berch (2005) quando o autor afirma que o indivíduo que compreende os sentidos de número é capaz de inventar procedimentos para a resolução de operações matemáticas e desenvolver estratégias para a resolução de problemas desde aqueles mais simples até os mais complexos.

Para Yang, Li e Li (2008), cinco competências estão relacionadas ao desenvolvimento do sentido de número: 1 . o entendimento do significado de números e as operações; 2. o reconhecimento da dimensão relativa do número; 3. a capacidade de compor e decompor números; 4. o reconhecimento dos efeitos relativos de operações; e 5. o julgamento do raciocínio dos cálculos mentais. Tais componentes são explicitados em seguida, de acordo com a proposta de Yang, Li e Li (2008), e se configuram no item sobre o método, como os objetivos específicos desta pesquisa.

$\mathrm{O}$ entendimento do significado de números e das operações refere-se à compreensão do Sistema de Numeração Decimal. Isso implica a capacidade dos indivíduos de compreenderem a lógica do sistema de numeração e seus elementos, ou seja, de entender a noção de valor de lugar, dos padrões numéricos e das várias formas de se representarem os números. O reconhecimento do tamanho relativo dos números consiste na competência de reconhecer a dimensão dos números. Isso implica, por exemplo, como apontado por Yang, Li e Li (2008), na capacidade de o aluno comparar frações, sem que para isso tenha que recorrer ao uso de métodos padronizados, como é o caso do Mínimo Denominador Comum (MDC). 
A capacidade de compor e decompor números refere-se à flexibilidade na resolução de cálculos. Nesse sentido, ao deparar com uma questão aparentemente complexa, o indivíduo toma a iniciativa de resolvê-la por meio da decomposição ou composição dos números pertencentes àquela sentença, de modo a favorecer a resolução. No cálculo $32+25$, por exemplo, uma solução possível, seguindo esse componente do sentido do número, seria decompor o número 32 e o número 25, montando a seguinte operação: $30+2+20+5$. Em seguida, somar $30+20$ e obter 50 . Posteriormente, somar $2+5$ e obter 7 . O último cálculo dessa sequência seria 50+7, chegando ao resultado 57. O reconhecimento dos efeitos relativos de operações com número, por sua vez, diz respeito à capacidade de perceber a forma como as quatro operações (adição, subtração, multiplicação e divisão)

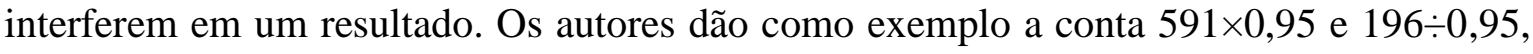
que têm como resultados 561,45 e 206,3157894736842, respectivamente.

Yang, Li e Li (2008) afirmam que, ao adquirir esse componente do sentido de número, o indivíduo é capaz de estimar, mesmo sem fazer contas no papel, que a multiplicação $561 \times 0,95$ resultará em um número com menos algarismos do que a divisão 196 $\div 0.95$. O julgamento da razoabilidade dos resultados de cálculos, por sua vez, refere-se à competência dos indivíduos de calcular mentalmente e estimar se um resultado é ou não coerente para determinada operação. Neste caso, assim como nos outros componentes anteriores, o indivíduo não precisa recorrer ao uso de regras nem cálculos no papel para proferir a sua estimativa.

Tomando por base os conceitos apresentados neste item, podemos afirmar que desenvolver a aquisição do conceito de número favorece a aprendizagem da Matemática escolar. Salientamos, nesse sentido, um consenso entre os autores (Fávero, 2011; Muniz, 2014; Brandt, 2002), de que o desenvolvimento do conceito de número e a compreensão da lógica das relações do Sistema de Numeração Decimal são imprescindíveis para a 
apreensão de conceitos matemáticos posteriores. Considerando esse consenso e o fato de que acabarmos de abordar o conceito e os significados dos números, no próximo item vamos nos debruçar sobre questões relativas ao desenvolvimento da compreensão do Sistema de Numeração Decimal.

\subsection{A Compreensão do Sistema de Numeração Decimal (SND)}

O Sistema de Numeração Decimal (SND) foi construído de forma coletiva e é amplamente utilizado na sociedade, podendo ser apontado como "uma tecnologia da inteligência humana" (Brandt, Camargo \& Rosso, 2004, p. 90). De origem indo-arábica, o SND é considerado mais econômico que outros sistemas de numeração antigos, já inventados pela humanidade, pois utiliza apenas 10 algarismos para registrar uma infinidade de números (Curi, Santos \& Rabelo, 2013). De acordo com Duval (2013), apesar de esse sistema oferecer mais possibilidades que os sistemas de numeração romano ou grego, a sua aquisição não é um processo simples. Sua aquisição requer a utilização desse sistema desde muito cedo, para que progressivamente possa se tornar, como refere o próprio autor, mais transparente para os seus usuários.

De acordo com Guimarães (2012), são elementos desse sistema: a noção de base, o valor posicional, os princípios aditivos e multiplicativos e o uso do numeral zero. Segundo essa autora, essas regras envolvem processos complexos que devem ser bem compreendidos; caso contrário, poderão se tornar apenas habilidades incorporadas ao repertório intelectual, sem nenhum sentido.

O valor posicional, por exemplo, refere-se à possibilidade de um número poder ocupar diferentes posições no sistema de numeração e, assim, assumir diferentes valores (Santana, 2014). Tanto o princípio aditivo como o princípio multiplicativo estão 
diretamente ligados ao conceito de valor posicional. Santana (2014) explica que o princípio aditivo do SND se refere à possibilidade de somar os valores posicionais (valores relativos) dos algarismos, que formam um determinado número, e, com isso, encontrar o seu valor absoluto. Ela exemplifica esse princípio utilizando o número 14, no qual: 10 (valor relativo do 1$)+4$ (valor relativo do 4$)=14$ (valor absoluto). Já no princípio multiplicativo, os valores relativos dos algarismos dos numerais podem ser encontrados a partir da multiplicação de cada um desses algarismos pelo valor da casa decimal que ocupa. Ou seja, no numeral 532 temos: $5 \times 100=500$ (valor relativo do 5 ); $3 \times 10=30$ (valor relativo do 3 ); $2 \times 1=2$ (valor relativo do 2 ).

Apropriar-se dessas particularidades do Sistema de Numeração Decimal requer um árduo processo de assimilação, como expõem Brandt e Rosso (2010). Esses autores apontam que as relações do SND são organizadas cognitivamente pelas crianças, por meio da operatividade, sendo essa a forma que gera a compreensão da lógica do SND. Para eles, a aprendizagem desse sistema, no âmbito escolar, não pode valorizar apenas a sua manipulação e a sua utilização para o registro de quantidades e resolução de algoritmos. Conforme esses autores, dois processos psicológicos são fundamentais nessa construção do entendimento do SND. O primeiro deles é a equilibração que, assim como proposta por Piaget (1975), consiste em um processo de adaptação e posterior tomada de consciência dos conceitos com os quais se está lidando. O segundo processo diz respeito à abstração reflexionante, que é composta de dois componentes que são inseparáveis: o reflexionamento e a reflexão. O reflexionamento seria uma espécie de projeção, na qual os conhecimentos adquiridos nas esferas inferiores são direcionados a patamares superiores da nossa compreensão. A reflexão, por sua vez, seria o ato de reconstrução e reorganização daquilo que foi adquirido e projetado durante o processo de reflexionamento (Nogueira \& Pavanello, 2008). 
É de relevante importância para os professores compreenderem esses processos do desenvolvimento cognitivo para a aprendizagem do SND. Contudo, como nos mostra Fávero (2007a, 2009, 2011, 2014), o entendimento de como a construção do conhecimento ocorre requer muito mais do que a simples compreensão de como as estratégias cognitivas se organizam. Implica a análise dos valores sociais envolvidos nas atividades e também nos procedimentos. Nesse sentido, os erros produzidos pelos alunos não podem passar despercebidos no momento da análise de suas produções do SND e da Matemática como um todo.

As autoras Lerner e Sadovsky (1996) descrevem, em um estudo clássico, várias estratégias desenvolvidas pelas crianças, no decorrer da construção da compreensão dos conceitos ligados ao SND, que podem vir a ser consideradas como erros pelos professores, caso estejam focados apenas na resposta dos indivíduos e não no processo de elaboração dessas respostas. As autoras apresentam o caso de uma criança, no início da alfabetização, que, ao comparar dois numerais, 23 e 9, baseou-se na quantidade de algarismos para apontar qual deles era o maior. Em outro exemplo, as crianças afirmaram que 99 era maior que 100 por que o algarismo nove presente no numeral 99, é maior que e o um e o zero presentes no numeral 100. Podemos ver, a partir dessas respostas, que as crianças ainda não haviam compreendido a lógica do valor relativo dos números, estando em processo de construção da compreensão da formação dos números.

Salientamos, porém, que as dificuldades com o sistema de numeração não se restringem às crianças. Fávero e Soares (2002) descreveram um estudo centrado na compreensão da notação do sistema numérico envolvendo dois adultos em processo de alfabetização. Esses indivíduos, considerados com dificuldades de aprendizagem, vivenciaram um processo de intervenção, no qual demonstraram dificuldades no manejo das operações aritméticas, em especial, da subtração. As autoras concluíram que esses 
adultos apresentavam uma "conceituação insuficiente da notação decimal" com a qual estavam trabalhando na escola (Fávero, 2014, p. 350). O que confirma o que disseram outros autores, referidos neste trabalho a respeito da complexidade do processo de compreensão do SND.

Para Brandt e Rosso (2010), erros como os que foram aqui apresentados podem decorrer de abstrações diferenciadas ou de assimilação incompleta. Assim, não se pode afirmar que houve erro da criança ou do adulto, mas, sim, que há uma incompreensão dos princípios do SND. Segundo Muniz (2009), o erro não indica ausência de conhecimento, apenas que o indivíduo mobilizou esquemas inadequados para a situação que lhe havia sido proposta. Sendo assim, os indivíduos devem ser levados a refletir sobre suas respostas para atingir graus mais complexos de raciocínio. Muniz (2009) afirma que, em situações como essas, o professor tem o papel preponderante "de oferecer situações nas quais esses esquemas não se mostrem mais válidos ou eficientes. Pois desse modo, o aluno procurará reconstruir seus esquemas e também elaborar novos esquemas, que possam dar conta de uma classe de situações mais amplas” (Muniz, 2009, p. 127).

Assim, a partir dessas reflexões apresentadas, podemos advogar pela importância dos conceitos do SND para as construções dos significados matemáticos. Curi et al. (2013) acreditam, com base na análise que realizaram de respostas dadas por alunos do $5^{\circ}$ ano, em avaliações do SAEB, que essa devida importância que deve ser dada aos conceitos do SND tem sido deixada de lado. Segundo eles, os docentes têm mediado esses conceitos, a partir de uma falsa ideia de que são conteúdos de fácil compreensão. Esses autores afirmam que alunos do $5^{\circ}$ ano estão apresentando erros, na avaliação do SAEB, por exemplo, que não condizem com os erros esperados para os alunos dessa fase de escolarização. Em outras palavras, esses alunos estão apresentando erros esperados para alunos de níveis menos avançados. 
Essa argumentação dos autores confirma o que Fávero (2000, 2009, 2011) aponta em seus estudos. A autora constata que um dos grandes problemas da aprendizagem da Matemática está ligado à incompreensão da lógica do Sistema de Numeração Decimal, por parte dos alunos das diversas fases da escolarização.

O que esses autores estão nos mostrando é que não podemos desconsiderar a complexidade e a importância dos conceitos matemáticos iniciais que são mediados aos alunos nas aulas de Matemática. Aqui enfatizamos tanto os conceitos ligados ao SND, como aqueles relacionados à aquisição do conceito e ao sentido de número, que discutimos no item anterior. Acreditamos, no entanto, que a discussão não se encerra com a indicação de que ambos os conceitos apresentados até aqui sejam de compreensão complexa. É necessário discutir as formas e os elementos que são envolvidos no processo de mediação desses conceitos. Por esse motivo, apresentaremos, no item seguinte, elementos fundamentais envolvidos no processo de ensino que contemplem essas questões apresentadas até esse ponto do trabalho. 


\subsection{A Interação Social, a Resolução de Problemas e a Representação e o Registro, como elementos na formação de conceitos}

Com base nas ideias apresentadas ao longo desta fundamentação teórica, para concluí-la, podemos retomar alguns aspectos consensuais. Em primeiro lugar, a nossa pesquisa bibliográfica aponta para a necessidade de se rever a prática de ensino, inserida em um contexto no qual o uso da memorização de fatos e cálculos e regras matemáticas já não são mais suficientes para garantir a compreensão da Matemática (Fávero, 2012; Moro, 2004). Em segundo lugar, podemos dizer que há também um consenso em relação ao tipo de atividade e de materiais que devem ser propostos em sala de aula de Matemática (Ribeiro, 2008; Batista \& Spinillo, 2008). Os autores enfatizaram insistentemente que as atividades devem se relacionar com o contexto dos alunos, basear-se na resolução de problemas, possibilitar o uso de estratégias pessoais de cálculo e não somente basear-se na manipulação de algoritmos. Além disso, os materiais concretos utilizados, tanto para o ensino como para o apoio às resoluções, devem ter uma clara relação da sua representação com o conceito matemático que pretendem reproduzir.

Sendo assim, uma proposta que articula todas essas questões e as fundamentam, do ponto de vista psicológico, é a proposta de Fávero (2000, 2002, 2005, 2009a; 2009b, 2011, 2012, 2014), que aponta para o fato de "que a atividade no processo de ensinoaprendizagem é mediada" (Fávero, 2009b, p. 14). Além disso, a referida proposta articula, no processo de intervenção, a interação social, a resolução de problemas e o registro e a representação dos conceitos (Fávero, 2002).

Nessa concepção, o ser humano é um indivíduo em constante atividade que constrói, a partir dela, o seu próprio conhecimento. Uma construção que é dialética e envolve tanto a interação como a adaptação do indivíduo com o meio sociocultural, baseada nos processos de internalização e externalização dos sistemas de signos e de sua 
representação para fundamentar a tomada de consciência (Fávero, 2005a; 2007, 2009, 2011). Portanto, neste item final da fundamentação teórica, abordamos três aspectos que são de suma importância para o desenvolvimento de competências matemáticas e para a formação de conceitos: a interação social, a resolução de situações-problemas, a representação e o registro. De acordo com Fávero (2009b), a consideração desses três elementos, no processo de ensino e de pesquisa, permite uma mudança na forma de condução dos processos de ensino. O ensino deixa de ser baseado na díade alunoconhecimento e passa a se sustentar na tríade aluno-conhecimento-professor. Para a autora, essa é uma prática de ensino na qual se privilegia a interlocução entre os sujeitos e não a simples transmissão de conteúdo.

É nesse sentido que abordaremos os três aspectos aos quais nos referimos (interação social, resolução de situações-problemas e a representação e o registro). Em primeiro lugar, apresentamos a situação de interação social que, segundo Fávero (2014), é um importante elemento para o desenvolvimento psicológico e o desenvolvimento das competências matemáticas. A autora evidencia que nas interações ocorrem dois processos diferentes de regulações: as regulações cognitivas e as regulações sociais. Contudo, é preciso esclarecer, segundo a própria autora, que essas regulações só têm uma repercussão na aprendizagem do indivíduo quando ocorre o processo de autorregulação. Ou seja, quando as elaborações que cada indivíduo realiza em uma dada situação de interação, reverberam nos seus esquemas cognitivos.

Segundo Fávero (2009b), no processo de autorregulação, a tomada de consciência é o elemento chave. Para Piaget (1977), a tomada de consciência se refere ao movimento que o pensamento do indivíduo realiza para transformar um esquema de ação em um conceito. Nesse sentido, a tomada de consciência pode ser desencadeada tanto por inadaptações que o sujeito encontra como pela a busca de um novo objetivo. Esse processo é "crucial para o 
desenvolvimento do conhecimento" (Fávero, 2014, p. 357). Sendo assim, o movimento que desencadeia a tomada de consciência

procede da periferia para o centro, sendo esses termos definidos em função do percurso de um determinado desempenho. Este começa, com efeito, com a busca de um fim, donde os dois dados de observação iniciais que podemos denominar periféricos enquanto ligados ao desencadeamento e ao ponto de aplicação da ação: a consciência do objetivo a alcançar. Diremos, então, que a tomada de consciência, parte da periferia (objetivos e resultados), orienta-se para as regiões centrais da ação quando procura alcançar o mecanismo interno desta: reconhecimento dos meios empregados, motivos de sua escolha ou de sua modificação durante a experiência. (Piaget, 1977, p. 198)

Piaget (1978) nos mostra, também, que no processo de tomada de consciência observa-se, em um primeiro momento, uma troca entre a conceituação e a ação e, em um segundo momento, uma modificação total desse processo, que se caracteriza pelo fato de que os conceitos já internalizados passam a oferecer elementos para a constituição da ação. Dessa forma, considerando que a tomada de consciência é um dos elementos chave para o desenvolvimento de competências matemáticas, temos, portanto, que investigar como desencadear esse processo no contexto do ensino, seja na sala de aula seja na pesquisa.

Fávero (2014) propõe, nesse sentido, que por meio de atividades realizadas com objetos e também pela mediação realizada pelas pessoas, ou seja, pela mediação semiótica, os indivíduos sejam levados a elaborar suas concepções a respeito das diferentes áreas do conhecimento, tomando consciência dos conceitos mediados. Vygotsky (1984) nos mostra que o mediador (professor, tutor a distância, pesquisador) não deve fornecer os caminhos prontos para que o indivíduo chegue ao êxito de uma determinada tarefa. Mais que isso, deve favorecer os meios para que os indivíduos busquem espontaneamente métodos ou símbolos que possam ser incorporados a suas operações mentais, a fim de chegar à resolução de problemas ou de tarefas. O indivíduo, nesse contexto, chega ao domínio do seu próprio comportamento por meio da assimilação de elementos externos que, posteriormente, se transformam em operações internas, cada vez mais, complexas. 
Para contemplar essas questões, portanto, podemos recorrer à resolução de situações-problemas, que se trata do segundo aspecto, dos três que apontamos inicialmente. Para Fávero (2011), as situações-problemas se apresentam como um instrumento que serve para mediar o conhecimento em uma dada situação de interação social. Essa defesa se coaduna com a proposição de Vergnaud (1994), o qual acredita que os conceitos adquirem sentido para os indivíduos a partir de problemas e situações a serem resolvidos.

Essas situações-problemas podem ser desenvolvidas de diferentes formas, uma delas, e que se relaciona com a forma como desenvolvemos as nossas atividades de intervenção durante a pesquisa, refere-se aos cenários de investigação. De acordo com Skovsmose (2000; 2009), os cenários de investigação são ambientes nos quais se torna possível que os sujeitos atribuam significados para as situações de aprendizagem matemática na sala de aula. Os cenários de investigação são descritos como um lócus para o trabalho de investigação na matemática.

Referente aos cenários de investigação, podemos apontar pelo menos quatro pontos essenciais. O primeiro deles diz respeito à possibilidade de os alunos, nesses cenários, formularem questões a respeito das situações de resolução de problemas nas quais estão envolvidos. O segundo diz respeito ao processo de exploração das relações matemáticas, possibilitado por esses ambientes. O terceiro ponto refere-se à necessidade de os alunos aderirem ao convite do professor para participar das situações pertinentes a um determinado cenário de investigação, para que esse possa ser realizado. O interesse por determinado tema por parte dos estudantes é o que define a sua existência. Por fim, o quarto aspecto diz respeito à questão da propriedade relacional, que, em outras palavras, significa que uma atividade matemática, para ser caracterizada como cenário de investigação, requer uma relação entre os sujeitos envolvidos (alunos e professor) no ensinar e aprender matemática (Skovsmose, 2000). 
Esse autor acrescenta que podemos criar diversos cenários de investigação na sala de aula e explica isso por meio de exemplos de possíveis cenários que podem ser empreendidos nas aulas de matemática, tais como: cenários em relação a matemática da culinária, cenários da matemática das construções, ou ainda cenários da matemática das rochas (Skovsmose, 2009). Para esse autor, a utilização dos cenários de investigação permite aos docentes modificar as suas aulas, transitando do que ele aponta como paradigma de exercícios para uma abordagem de investigação. No paradigma de exercícios, a ênfase das atividades de ensino se encontra na resolução de exercícios, na qual há apenas uma resposta correta para as questões propostas aos estudantes. Na abordagem de investigação, por sua vez, é possibilitado aos alunos decidir e propor diferentes formas de resolução para um mesmo problema.

Sendo assim, considerando, a mediação semiótica na situação de interação, bem como a resolução de situações-problemas, surge o terceiro aspecto desta exposição: $a$ representação e o registro. Vergnaud (2009b) explica que é a representação que o sujeito faz de uma dada situação que fundamenta os meios e os caminhos utilizados por ele para a resolução de um problema, de modo a atingir um determinado objetivo suscitado pelas atividades escolares. Esse autor salienta que a noção de representação não pode ser reduzida à noção do símbolo e do signo, pois, segundo ele, a representação também está relacionada à noção de conceito.

Para Duval (2012), as dificuldades dos alunos em Matemática decorrem da não compreensão das diversas transformações de representações semióticas com as quais os alunos se deparam. Para esse autor, essas representações são de suma importância para a atividade cognitiva. Com isso, ele argumenta em favor do uso dessas representações, referentes aos objetos matemáticos, no ensino, de modo a gerar a compreensão conceitual. Isso porque, segundo esse mesmo autor "os objetos matemáticos, começando pelos 
números, não são objetos diretamente perceptíveis ou observáveis com a ajuda de instrumentos. O acesso aos números está ligado à utilização de um sistema de representação que os permite designar" (Duval, 2013, p. 14).

Duval (2012) sugere cuidado para que não se confunda o objeto matemático com a representação dele. Contudo, em muitas situações de aprendizagem, os sujeitos lidam apenas com a representação e não com os objetos matemáticos. Assim, o autor indica como imprescindível para o ensino da Matemática a mobilização de diversas formas de registro de representação semiótica, possibilitando, dessa maneira, a aquisição conceitual dos diversos objetos matemáticos e a compreensão de sua representação.

O ensino da matemática, segundo Duval (2013), deve ir além da simples identificação das concepções dos alunos a partir apenas da análise de seus erros. Para ele, ao aderir a essa abordagem cognitiva, há a possibilidade de descrever o modo como o pensamento funciona e como o indivíduo compreende, opera e, mesmo, controla todos os processos matemáticos envolvidos em um contexto de resolução de atividades matemáticas, na escola.

Essa postura corrobora com o defendido por Vygotsky (1984), ao afirmar que "a complexidade crescente do comportamento das crianças reflete-se na mudança dos meios que elas usam para realizar novas tarefas e na correspondente reconstrução de seus processos psicológicos” (Vygotsky, 1984, p. 96).

Com base nas considerações apresentadas é que se justifica a nossa decisão pelo uso da pesquisa de intervenção, fundamentada na proposição de Fávero (2000, 2009, 2007, 2011), como método de investigação. Acreditamos na pertinência dessa proposta, justamente pelo fato de que ela, ao mesmo tempo, colhe dados sobre as competências e dificuldades dos indivíduos e também contribui para o desenvolvimento de novas competências e para o seu desenvolvimento psicológico. Esses três aspectos, que foram 
abordados nesse item, serão retomados na parte deste trabalho que se refere ao método, quando descrevermos o nosso procedimento de pesquisa. 


\section{Parte 2 - A Pesquisa de Intervenção: o desenvolvimento de competências numéricas}

\subsection{O Problema e o Método}

Como já referido nos itens anteriores desta dissertação, temos evidenciado que os sujeitos têm enfrentado diversas dificuldades, relacionadas aos conceitos da Matemática escolar. Diante desse contexto, tínhamos como problema de pesquisa evidenciar a natureza dessas dificuldades. Sendo assim, assumimos a proposta de Fávero (2000, 2001, 2005, 2009a, 2009b, 2011), que, como já informamos no item final de nossa fundamentação teórica, se centra em três aspectos básicos: 1) a situação de interação, 2) a resolução de situações-problemas e 3) o registro e a representação. Desse modo, estamos, mais uma vez, considerando o processo de desenvolvimento humano dos indivíduos.

As situações-problemas relacionadas ao tema geral da intervenção ou, como se refere Skovsmose (2000; 2009), o cenário de investigação relativo à nossa pesquisa foi o planejamento para a abertura de uma fábrica de doces de festa, perpassaram por diversas competências matemáticas trabalhadas no decorrer dos anos iniciais do Ensino Fundamental. As sessões de intervenção psicopedagógica tiveram como espinha dorsal de suas atividades a proposição de situações-problemas focadas no desenvolvimento da lógica do Sistema de Numeração Decimal e do sentido de número. Esse instrumento, por sua vez, esteve em consonância com o que é defendido por Vergnaud (1990, 2009a, 2009b) e por Fávero e Souza (2001).

Assumimos, em nossa pesquisa, a proposta metodológica de Fávero (2000, 2001, 2005, 2007, 2009a, 2009b, 2011, 2012), que articula Psicologia e Conhecimento, assim como fizeram outras pesquisadoras, tais como: Vieira (2002), Bonfim (2005), e Pina Neves (2008). Semelhante a elas, adotamos a pesquisa de intervenção de abordagem cognitivo- 
desenvolvimental como nosso método e utilizamos as sessões psicopedagógicas interativas centradas na proposição de situações-problemas como procedimento.

O projeto desta pesquisa foi apresentado ao Comitê de Ética em Pesquisa do Instituto de Ciências Humanas e foi aprovado em 19/02/2015 (ver Anexo 1). Após essa aprovação, apresentamos o projeto à Secretaria de Educação que nos concedeu a autorização para a realização da pesquisa (Anexo 2). Somente após essas autorizações é que fomos até a Escola para darmos início à coleta de dados.

O procedimento de investigação estruturou-se em três tarefas distintas e articuladas, assim como proposto por Fávero (2003). A primeira dessas tarefas dizia respeito à avaliação das competências e das dificuldades do sujeito. A segunda consistia na sistematização das sessões de trabalho, considerando os objetivos e a descrição das atividades propostas. A terceira e última das três tarefas referia-se à análise minuciosa do desenvolvimento das atividades de cada sessão, de modo que fossem explicitados: a sequência de ações dos sujeitos em situação de intervenção; o significado de suas ações e a relação desses significados com a aquisição de conceitos; e ainda, a análise da natureza da mediação estabelecida entre o adulto (pesquisador, professor) e o sujeito.

Dois foram os nossos objetivos gerais da pesquisa: 1) desenvolver, por meio de um procedimento psicopedagógico, competências matemáticas conceituais junto a alunos do $5^{\circ}$ ano do Ensino Fundamental, com histórico de fracasso escolar, enfatizando a Lógica do Sistema de Numeração Decimal e a sua notação, de modo a evidenciar as dificuldades na Matemática escolar; 2) obter dados que demonstrassem a natureza dessas dificuldades e a relação entre dificuldades e competências. Elegemos cinco objetivos específicos para nosso estudo. Esses objetivos, por sua vez, coincidem com os cinco componentes do sentido de número apontados no trabalho de Yang, Li e Li (2008) e ao qual fizemos referência no item 1.2 desta dissertação. Retomamo-los a fim de ressaltá-los: 1) levar os 
sujeitos a compreender o significado do número e suas operações; 2) desenvolver a compreensão do valor relativo dos números; 3) encorajar o uso das estratégias de composição e decomposição dos números; 4) possibilitar o desenvolvimento da percepção

de que forma as quatro operações afetam o resultado das operações; e 5) possibilitar situações que os sujeitos possam julgar se o resultado de uma determinada operação é aceitável ou não.

\subsection{Sujeitos}

Solicitamos às professoras do quinto ano, da escola onde foi realizada a pesquisa, que nos apresentassem alunos com dificuldades na Matemática escolar e que não tivessem qualquer indicação para atendimento educacional especializado. Foram-nos apontados 11 alunos dos quais selecionamos um sujeito do sexo feminino e o outro, do sexo masculino. Ambos apresentavam histórico de repetência no Ensino Fundamental. Considerando o sigilo das identidades de ambos, neste trabalho, esses sujeitos são denominados: Af quando nos referirmos ao sujeito do sexo feminino, e Am quando nos referirmos ao sujeito do sexo masculino.

\subsubsection{Participante Af}

A participante Af nasceu em 14 de fevereiro de 2004, no estado de Minas Gerais, e residia na cidade de Taguatinga com a avó, um tio e três irmãs. Sempre estudou no Distrito Federal, em uma Escola Classe de Taguatinga, tendo sido matriculada em 2008, no $1^{\circ}$ período da Educação Infantil. Em seu histórico, a aluna não possuía qualquer indicação de diagnóstico médico que pudesse interferir em sua aprendizagem. Diante disso, a docente da 
aluna não via necessidade de encaminhamento para a equipe psicopedagógica (psicóloga e pedagoga), ela apenas indicava a participação no projeto interventivo de caráter pedagógico, ou seja, atividades no horário contrário às aulas, com foco nas dificuldades apresentadas na sala de aula. Af tinha histórico de repetência escolar, no $3^{\circ}$ ano do Ensino Fundamental, e em seu relatório escolar havia a indicação de dificuldades em todos os anos escolares, do $1^{\circ}$ até o $5^{\circ}$ ano.

\subsubsection{Participante Am}

O participante Am nasceu em 13 de janeiro de 2004, no Distrito Federal, e residia na cidade de Taguatinga com a avó e o avô. Possuía um irmão, filho do segundo casamento do pai, mas não morava com ele. Sempre estudou no Distrito Federal, sendo que em 2008 ingressou no $1^{\mathrm{o}}$ período da Educação Infantil em uma Escola Classe de Taguatinga. $\mathrm{O}$ aluno não possuía indicação de diagnóstico médico que pudesse interferir em sua aprendizagem. Em seu histórico escolar havia o registro de reprovação no $5^{\circ}$ ano do Ensino Fundamental, em decorrência de resultados insatisfatórios na disciplina de Matemática.

\subsection{Os Procedimentos}

\subsubsection{Procedimento de Coleta de Dados}

A coleta de dados ocorreu no período de março a setembro do ano de 2015. Todas as sessões foram realizadas nas acomodações do Laboratório de Aprendizagem da escola, sempre no período matutino, e tiveram duração média de 40 minutos. Após obtenção da autorização para o desenvolvimento da pesquisa junto ao Comitê de Ética do Instituto de Humanidades da Universidade de Brasília e da Secretaria de Educação, realizamos uma 
reunião com as famílias dos prováveis participantes. Apresentamos a elas a proposta da pesquisa e, após aceitarem a participação das crianças, pelas quais eram responsáveis, solicitamos a assinatura do Termo de Consentimento Livre Esclarecido (TCLE) (Anexo 3) e do Termo de Utilização de Voz e de Imagem (Anexo 4).

O primeiro encontro com os participantes Af e Am se deu uma semana após a reunião com as famílias. Primeiro, houve uma conversa informal e individual, na qual apresentamos a proposta da pesquisa a cada um deles. Explicamos como seriam os encontros e esclarecemos que seus responsáveis já haviam autorizado a sua participação, mas que podiam rejeitar isso se quisessem. Ambos, no entanto, decidiram por participar. Assim, lemos o Termo de Assentimento (Anexo 5) e lhes solicitamos que o assinassem.

O procedimento de coleta de dados aconteceu em duas fases distintas. Na primeira, realizamos a avaliação individual das competências e dificuldades matemáticas dos participantes. Na segunda, realizamos sessões de intervenção psicopedagógica, interativas, com base nos dados obtidos nas sessões de avaliação. Tanto as sessões da primeira fase como as da segunda fase foram registradas em áudio e transcritas na íntegra.

O registro das transcrições foi realizado de acordo com a proposta de Tian, Jimarkson e Singhasiri (2011), na qual são previstas notações para serem inseridas nas transcrições de áudio. Cada uma delas indica um acontecimento não verbal que pode ocorrer durante o desenvolvimento de uma conversa. Entre esses acontecimentos, podemos citar: tempo de silêncio após a fala de outro interlocutor, risos, interferências de pessoas alheias ao ambiente da gravação. A seguir, apresentamos um quadro com as notações que utilizamos nas transcrições das sessões. 
Tabela 5 - Símbolos propostos por Tian, Jimarkson e Singhasiri (2011) para a ampla transcrição.

\begin{tabular}{|c|c|}
\hline Símbolo & Significado \\
\hline$\cdots$ & $\begin{array}{l}\text { Três pontos indicam uma pausa perceptível menor que } 3 \text { segundos dentro de } \\
\text { uma fala. }\end{array}$ \\
\hline$(.3)$ & Número dentro de parênteses mostra duração de pausa maior que 3 segundos. \\
\hline · & Um ponto final indica uma pausa, sugerindo finalização da sentença. \\
\hline$?$ & $\begin{array}{l}\text { Um sinal de interrogação indica uma crescente inflexão e não necessariamente } \\
\text { uma questão. }\end{array}$ \\
\hline LETRAS MAIÚSCULAS & CAPS indica um tom enfático. \\
\hline I & Uma barra indica uma expressão repetida por um mesmo falante. \\
\hline$=$ & $\begin{array}{l}\text { Sinal de igual indica declarações proferidas de forma truncada, uma após a } \\
\text { outra, sem pausa. }\end{array}$ \\
\hline\{\} & As chaves vazias indicam comentários do transcritor. \\
\hline$(?)$ & $\begin{array}{l}\text { Um sinal de interrogação dentro de parênteses indica um fragmento inteligível } \\
\text { durante a gravação. }\end{array}$ \\
\hline @ & Um“@” indica riso dos falantes. \\
\hline
\end{tabular}

A primeira fase da coleta de dados, chamada de avaliação psicopedagógica, aconteceu em duas etapas distintas. Na primeira etapa, realizamos uma entrevista individual focando os seguintes eixos: história escolar, concepções sobre a escola, noção de tempo, noção espacial, relações sociais, atividades escolares favoritas, concepções sobre escolaridade e competência escolar. Além disso, dialogamos sobre o caderno escolar e os registros nele contidos. Na segunda etapa dessa avaliação, utilizamos a Prova Conceitual de Resolução de Problemas Numéricos - ECPN - (Groupe Cimete, 1995) para identificar as competências e dificuldades dos participantes em Matemática. A finalidade dessa prova era obter dados relativos aos componentes do sentido de número e à compreensão do Sistema de Numeração Decimal. Essa atividade consistia em um grupo de situaçõesproblemas de Matemática, propostas oralmente para os sujeitos.

$\mathrm{Na}$ segunda fase de coleta de dados, ocorreram as sessões de intervenção psicopedagógica. Essas se constituíram em um total de 14 sessões e foram realizadas com os dois participantes da pesquisa, em interação. Com base nos dados obtidos na primeira 
fase (avaliação das competências e dificuldades dos sujeitos), desenvolvemos a segunda fase. Em cada sessão, seguimos focando um procedimento comum, descrito em Fávero e Soares (2002). Em primeiro lugar, partíamos da ideia que os sujeitos apresentavam os conceitos matemáticos em jogo em cada sessão. Em seguida, os encorajávamos a representar esses conceitos utilizando materiais; por fim, os instigávamos a registrar no papel da forma que preferissem ou conhecessem, essa noção inicial que tinham. Ao final das 14 sessões, realizamos duas entrevistas individuais com os participantes, semelhante à entrevista da primeira fase da pesquisa.

Nossas sessões foram permeadas de argumentações que pudessem levar os participantes a reelaborar o seu raciocínio inicial, representado em sua notação ou procedimento pessoal, de modo que posteriormente pudessem chegar à notação formal da Matemática e pudessem também tomar consciência da lógica subjacente aos conceitos. Entre as argumentações por nós realizadas, destacamos algumas como: Explica o que você fez. Por que você fez isso? O que isso significa? Como chegou a esse resultado? Vamos recontar essa quantidade de palitos que você colocou? Você concorda com o que o seu colega está dizendo?

\subsubsection{Procedimento de Análise dos Dados}

Compatível com a natureza qualitativa de nossa coleta de dados, o procedimento de análise dos dados obtidos, nas duas fases do procedimento de coleta (avaliação e intervenção), foi submetido a uma análise qualitativa. $\mathrm{O}$ fundamento para a realização dessa etapa foi a proposta defendida nos trabalhos de Fávero (2009a, 2009b, 2011), de Pina Neves (2008), de Fávero e Pina Neves (2009, 2013).

Desse modo, depois de transcrita na íntegra, a entrevista desenvolvida na primeira etapa, da primeira fase da coleta, foi tomada com um texto, assim como descrito em Fávero 
e Trajano (1998) e retomado em Fávero e Abrão (2006). As proposições dos sujeitos e as interlocuções foram consideradas como unidades de análise. Nessa análise foram considerados dois dados: as interlocuções entre pesquisadora e participantes como proposto por Fávero $(2005,2012)$, adotando a proposta de estudo de Chabrol e Bromberg (1999); e as notações produzidas pelos participantes, seguindo o estudo de Fávero e Oliveira (2004), isto é, considerando as construções dos indivíduos e os esquemas subjacentes as suas produções, assim como se refere Muniz (2009). A análise da primeira fase evidenciou as filiações entre competências e dificuldades e fundamentou a fase seguinte do estudo.

Cada sessão da segunda fase do estudo e também as duas entrevistas individuais, após serem transcritas na íntegra, foram analisadas considerando como na primeira fase: 1 . as interlocuções entre pesquisadora e participantes e entre os participantes, no sentido de atos da fala como proposto por Fávero $(2005,2012)$; 2. as notações produzidas por cada um dos participantes e as alterações das notações advindas das interlocuções com seu par e/ou com a pesquisadora.

Considerando os atos identificados na fala de cada um dos interlocutores apontamos em nossas análises as esferas às quais esses atos se associavam. As esferas que utilizamos foram: 1) esfera da informação; 2) esfera da avaliação; 3) esfera da interação; 4) esfera acional e 5) esfera contratual.

\subsection{Os Resultados Obtidos em Cada Fase}

Neste item da dissertação, apresentamos os resultados obtidos nas duas fases do procedimento de coleta de dados da pesquisa. Isto é, durante a avaliação das competências e dificuldades matemáticas dos participantes e durante as sessões interativas de intervenção 
psicopedagógica. Apresentamos também, uma discussão geral das sessões de intervenção e uma avaliação geral do estudo que abarca os dados das fases de avaliação e intervenção.

\subsubsection{Primeira fase: as entrevistas, a Prova ECPN (Groupe Cimete, 1995), as análises} e a discussão

\subsubsection{Participante Af}

Foram realizadas duas entrevistas nesta fase de coleta de dados. A primeira entrevista foi desenvolvida de acordo com os oito eixos já referidos no método: história escolar, interesses, concepções sobre a escola, noções de tempo, noções espaciais, relações sociais, atividades escolares favoritas e concepções sobre escolaridade e competência escolar. A segunda entrevista centrou-se na discussão em torno dos registros e produções do caderno de Matemática.

A primeira entrevista com Af teve duração de 52 minutos e se iniciou a partir de relatos de fatos ocorridos na infância e na história escolar da pesquisadora, de modo que pudesse ser estabelecido um ambiente propício para o desenvolvimento da entrevista. Dessa forma, deu-se início ao primeiro eixo da entrevista, história escolar. Af descreveu a sequência dos anos escolares que já havia cursado, assim como alguns acontecimentos ocorridos nesse período como, por exemplo, sua reprovação no terceiro ano. Ao se referir a essa reprovação, primeiramente Af atribuiu o seu fracasso a si mesma, dizendo que teria "conversado muito" durante as aulas. Em outro momento, conferiu sua reprovação a uma decisão de sua professora do terceiro ano, afirmando: "ela que mandou eu fazer de novo". No trecho abaixo, há a indicação de que Af não compreendia os reais motivos que a levaram à reprovação, uma vez que, segundo ela, cumpria todas as tarefas e recebia o conceito "muito bom" em todas as provas. 
$\mathrm{P}-\mathrm{E}$ você refez o terceiro ano por quê?

Af - Não sei. Acho que eu conversava muito.

$\mathrm{P}$ - $\mathrm{O}$ que isso tem a ver com fazer o terceiro ano duas vezes? Por que conversar muito fez você fazer o terceiro ano duas vezes?

Af - Não sei, a professora que fez. Ela que mandou eu fazer de novo.

$\mathrm{P}$ - Você fazia as tarefas?

Af - Hum, hum. Em todas as provas eu ganhava "muito bom"!

Ao ser instigada a falar sobre as provas do $4^{\circ}$ ano, Af se esquivou, apenas acenando negativamente com a cabeça, sem nenhuma palavra. Observamos que a concepção de Af a respeito de seu desempenho escolar estava intrinsecamente associada a erros e acertos, a notas e menções, como pode ser observado no trecho abaixo:

$\mathrm{P}$ - No ano passado tinha prova?

Af - $\{$ Acena positivamente com a cabeça $\}$

$\mathrm{P}$ - Você se saía bem nas provas?

Af - Não.

$\mathrm{P}$ - Por que não? Em que você não ia bem?

Af - Eu errava muito. Ganhava sempre "estude mais" e "regular".

$\mathrm{P}-\mathrm{E}$ por que você acha que a professora colocava regular? O que isso quer dizer?

Af -6 .

$\mathrm{P}$ - Isso é nota?

Af - É $[\ldots]$ a minha melhor nota foi sete.

Em relação ao eixo "concepções sobre a escola", Af afirmou que a instituição escola não era um lugar de diversão, no entanto a escola onde ela estudava era, sim, divertida. Indicou não apreciar tarefas que lhe impusessem dificuldades para a resolução e exemplificou dizendo que gostava de copiar textos, desde que não ultrapassassem duas páginas. Disse não gostar de "continhas" de Matemática, pois não sabia resolvê-las.

No eixo "interesses", a maior parte das atividades apontadas por Af como sendo suas favoritas envolvia o uso de tecnologias. Demonstrou motivação por computador, televisão, brinquedos eletrônicos e bonecas. Explicou que usava o computador para fazer tarefa de casa e ver vídeos sobre crianças, idosos e adolescentes. Indicou cinco desenhos animados da TV a cabo que gostava de assistir. Entre suas brincadeiras preferidas, ela 
destacou aquelas que utilizavam algum tipo de brinquedo e que contavam com a participação da irmã. Foram mencionados o brinquedo eletrônico Pega Peixe, bonecas e ursinhos.

Af identificou o dia do seu aniversário, os períodos do dia (manhã, tarde e noite), os dias da semana e a sucessão dos meses do ano. Soube também se posicionar em relação ao passado, presente e futuro e manusear o calendário fazendo contagem para frente e para trás no instrumento. Af relatou que seu aniversário já havia passado e que tinha sido em janeiro. Ao manusear o calendário, corrigiu-se: o seu aniversário era em fevereiro, sendo em janeiro o de sua irmã. Relatou como foram as comemorações, dividindo os acontecimentos pelos períodos do dia: manhã, tarde e noite.

Af demonstrou algumas noções básicas relativas ao espaço, nomeando a cidade em que nasceu e fazendo referência ao estado no qual essa cidade se localizava. Com relação aos locais mais próximos, como, por exemplo, o seu trajeto de casa para a escola, não evidenciou outras noções de espaço e, quando instigada, só fez menção ao meio de transporte.

A respeito das relações sociais, evidenciamos que suas interações eram restritas, fazendo referência apenas a uma amiga da escola e a uma brincadeira com ela. No ambiente fora da escola, nomeou duas crianças com quem partilhava brincadeiras.

Sobre as atividades escolares favoritas, Af relatou sua preferência pelo trabalho em grupo, justificando que a interação com colegas lhe permitia ter mais ideias. Ela fez referência a "continhas" para descrever sua atividade escolar favorita, demonstrando, nesse momento, motivação para aprendizagem da Matemática escolar.

No eixo "concepções sobre escolaridade e competência escolar", Af fez alusão aos termos "aluno" e "estudante", usados pela sua professora. Segundo ela, o termo "aluno" diz respeito àqueles que passivamente assistiam às aulas e não sabiam explicar o que 
aprendiam. Diferentemente, o termo "estudante" seria usado para identificar aqueles que sabiam exemplificar o que haviam aprendido. Af se colocou entre os 10 estudantes de sua sala de aula, que, segundo ela, demonstravam competência escolar.

A segunda entrevista teve duração de 43 minutos e 18 segundos. Como na primeira, a pesquisadora buscou Af em sua sala de aula. Ao caminhar em direção à experimentadora, a professora de Af ordenou que ela voltasse e pegasse o seu caderno. Af manteve o caderno perto de seu corpo, seguro pelos dois braços, mas depois o colocou em cima da mesa. Então a pesquisadora lhe solicitou que falasse das bonequinhas da capa do caderno e, com esse procedimento, foi possível abri-lo e folheá-lo.

Foram focadas três atividades do caderno de Matemática. A primeira constituía-se de oito algoritmos da soma e um da subtração, com o enunciado "efetue". Dos algoritmos da soma, três eram formados por duas parcelas e cinco por três parcelas. Observamos que todas as adições constituídas por mais de duas parcelas apresentavam um resultado diferente do esperado. Os registros do caderno de Af evidenciaram uma incompreensão dos algoritmos da adição e da lógica do Sistema de Numeração Decimal.

A segunda questão tinha o enunciado: "Complete o quadro, dando os valores absoluto e relativo de cada algarismo circulado, apresentando um quadro com três colunas”. Na primeira, estavam registrados os numerais; na segunda, os valores absolutos; e na terceira, os valores relativos. Ao ser perguntada sobre a questão, Af não evidenciou compreender o seu significado e nem o que se esperava que nela fosse feito. Diante da solicitação feita pela pesquisadora, Af leu corretamente o numeral 600.320, que aparecia no quadro descrito. Marcou de forma coerente os valores absoluto e relativo para o algarismo 3 desse numeral. Contudo, não demonstrou compreensão dos esquemas subjacentes a esses conceitos, operando e justificando suas respostas por meio de regras. 
Para o valor absoluto e o relativo do algarismo 1 no numeral 158, Af informou como resposta que o valor absoluto era 1; e o relativo, 111. Nota-se que Af sabia da necessidade de substituir os algarismos cinco e oito, respectivamente, das casas das dezenas e unidades, por outros algarismos, para indicar o valor relativo. No entanto, não tinha consciência de quais deviam ser esses números e nem o porquê do seu uso.

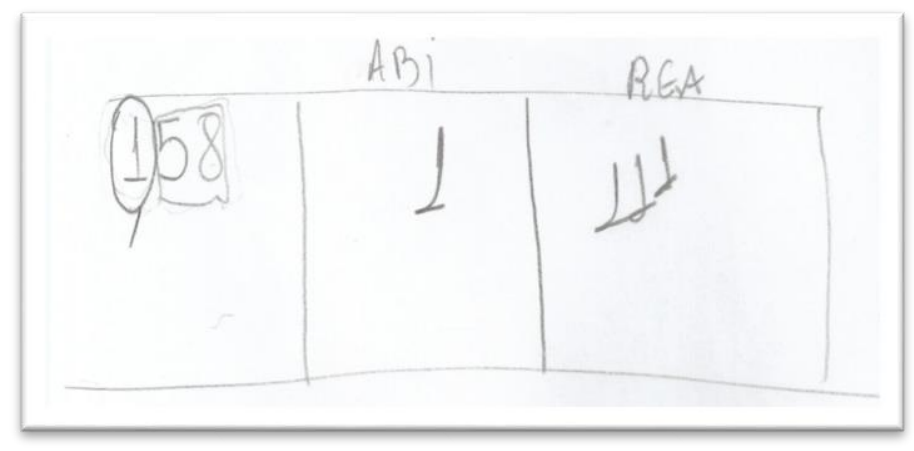

Figura 1. Exemplo de resolução dos valores relativo e absoluto do algarismo 1 no numeral 158.

A terceira atividade referia-se a ordens numéricas (unidade, dezena, centena, unidade de milhar e dezena de milhar). Af registrou o numeral 1203 para mostrar o que entendia sobre essas ordens. Escreveu, acima dos algarismos do numeral em questão, letras que pretensamente representariam as ordens do sistema de numeração. Porém, seus registros foram aleatórios, indicando que Af apenas memorizou os nomes de cada uma das ordens, sem compreender seu real significado.

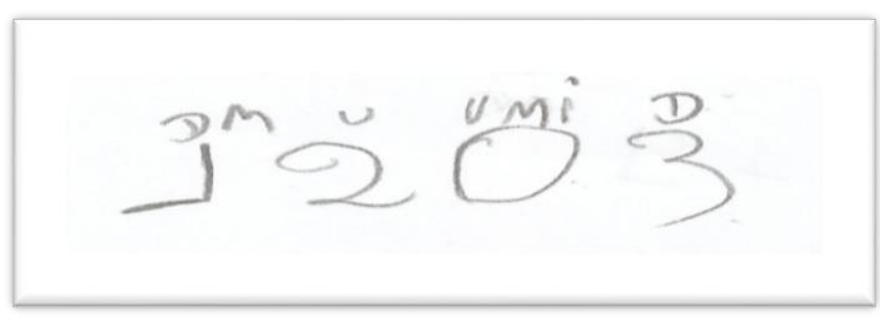

Figura 2. Notação produzida por Af para representar o numeral 1203 e suas respectivas ordens no Sistema de Numeração Decimal. 
Af demonstrou não compreender a importância do algarismo zero na formação dos numerais. Enfatizou que esse algarismo não poderia ser associado a nenhuma ordem. Isso indicou que, para Af, o zero só teria a função de substituir um espaço vazio.

Af contou corretamente dois reais em moedas, reconhecendo as moedas de cinco, dez, vinte e cinco e cinquenta centavos. Apresentou dificuldade apenas em demonstrar quantos centavos seriam necessários para formar um real, como descrito no trecho abaixo:

$\mathrm{P}$ - Quantas moedas de dez centavos, eu preciso, para ter uma moedinha de um real?

Af - De dez? Cinco!

P - Cinco? Af - Não, dez! [...]

Af - Hum... já tem um real.

$\mathrm{P}$ - Onde? Deixa eu ver.

Af - Aqui, já tem um real.

$\mathrm{P}-$ Aqui já tem um real? Aqui tem cinquenta...

Af - Vinte e cinco mais vinte e cinco?

$\mathrm{P}$ - Dá cinquenta?

Af - Vinte e cinco mais cinquenta? Um real. Aí. Aqui. Eu acho que vai dar.

Em uma situação-problema com picolés, as operações de divisão que envolviam números múltiplos de cinco, como 50 e 100, foram resolvidas por meio de cálculos mentais. Já naquelas em que apareceu o número 30, que é múltiplo de 3, Af recorreu ao suporte do material concreto - moedas - para chegar ao resultado. Isso indicava que Af estava em processo de desenvolvimento dos conceitos de multiplicação e divisão.

Constatamos que, ao propor questões novas ou algum desafio para Af, ela reagia pedindo para ir embora ou que parássemos de complicar. Outro ponto observado foi a constante referência ao erro. Sempre que iniciava as resoluções propostas, desistia na metade, alegando ter errado algo. Esses comportamentos indicavam que o fracasso escolar da participante gerou um sentimento de baixa autoestima em relação ao seu próprio desempenho. 


\subsubsection{Participante Am}

Desenvolvemos dois momentos de entrevista com Am, do mesmo modo realizado com Af. Iniciamos o primeiro momento da entrevista, que teve duração de 43 min22s, por meio de relatos de fatos da infância e do tempo de escola da pesquisadora, enfatizando o quinto ano. Isso nos permitiu iniciar o eixo história escolar.

Indagado sobre a série cursada no ano anterior, Am disse ter frequentado o quinto ano e que havia sido reprovado. Questionado se não havia estudado, respondeu ter estudado sim, mas não o necessário para passar de ano. Sobre diferenças entre os dois quintos anos, não apontou nenhuma. Para ele, as tarefas do ano em questão eram as mesmas do ano anterior.

Os próximos questionamentos realizados pela pesquisadora foram sobre quando Am foi para a escola pela primeira vez; o nome de sua primeira professora e sobre quais foram os fatos ocorridos nesse contexto. O participante respondeu apenas que a sua escola atual era a mesma onde iniciou seus estudos.

No eixo "interesses", arguimos sobre as atividades que realizava em casa, ao que nos disse que ficava assistindo televisão e jogando no computador. Sobre atividades ao ar livre, disse que gostava de jogar bola, especificamente futebol. Observamos, nesse item, que Am apreciava atividades baseadas no uso de tecnologias, mas que também valorizava as que envolviam o movimento do corpo.

No eixo "concepções sobre a escola", ao ser perguntado o que mudaria em sua escola, caso lhe fosse dada oportunidade de tomar essa decisão, respondeu que não mudaria nada. No entanto, quando lhe foi pedido que pensasse como se fosse o diretor daquela instituição, disse que mudaria tudo. Alegou que construiria tudo novamente e que deixaria a escola melhor, mas não muito diferente da escola atual. Com a mudança de 
perspectiva, de aluno para gestor, Am expressou a sua verdadeira opinião a respeito de sua escola.

No eixo "noções de tempo", mostrou ter domínio das noções elementares. Apontou a sucessão de um dia, identificou a data do seu aniversário, a sequência dos dias da semana e dos meses do ano, e fez referência ao passado, presente e futuro.

Ao manusear o calendário, realizou a contagem dos dias para frente e para trás de forma incorreta. Ora indicava uma quantidade maior, ora indicava uma quantidade menor que a esperada. Sempre que lhe era feita uma pergunta sobre alguma data no calendário, sua resposta era dada em formato de perguntas, assim como podemos evidenciar no extrato da interlocução que apresentamos a seguir. Pelo que se pode analisar dessas proposições, Am parecia apresentar insegurança em relação as suas respostas, o que podia sugerir medo de errar.

$\mathrm{P}-[\ldots]$ Descobre aí que dia é hoje, Am.

Am - Segunda?

$\mathrm{P}$ - Segunda. Descobre pra mim que dia é hoje.

Am - Quatro?

$\mathrm{P}$ - Você disse que hoje é segunda. O dia quatro tá na quarta-feira.

Am - Na segunda? Deixa eu ver. \{olha para o calendário, identifica uma segunda feira do mês e dá a sua resposta\} Dia nove?

$\mathrm{P}$ - Dia nove foi semana passada.

Am - DEZESSEIS?

$\mathrm{P}$ - Dezesseis, isso mesmo. [...].

No eixo "noções espaciais", disse que morava perto da sua escola. Explicou que vinha de sua casa até a escola sozinho e descreveu em detalhes esse trajeto. Fez também referência a uma cidade de praia que visitou nas férias, identificando, corretamente, uma cidade vizinha a ela. Esse dado nos mostrou que Am já tinha desenvolvido algumas noções a respeito do conceito de espaço.

No eixo "relações sociais", informou que na escola tinha "um monte" de colegas, mas não nomeou nenhum. Na rua, disse que brincava com meninos e meninas e que no 
jogo de queimada sempre era escolhido. As respostas de Am revelaram que ele valorizava a interação com várias pessoas e que, para ele, sentir-se parte de um grupo era muito importante.

As atividades escolares favoritas de Am eram, segundo ele, jogar bola e brincadeiras em grupo. A disciplina escolar que mencionou mais gostar foi ciências, salientando o estudo do corpo humano. A disciplina que disse não gostar era Matemática, apontando a divisão como uma operação que não sabia fazer.

Por fim, no eixo "concepções sobre escolaridade e competência escolar", Am afirmou que conhecia um bom aluno em sua turma. Descreveu-o dizendo que ele não sabia ler muito bem e que nem era muito bom em Matemática, mas que não conversava. Questionado se ele se considerava um bom aluno, nos respondeu que sim, pois não era bagunceiro. As respostas de Am indicaram que o bom aluno, em sua concepção, era o que não atrapalhava a aula.

O segundo momento da entrevista teve a duração de $34 \mathrm{~min} 36$ s e foi reagendado uma vez, pois, no primeiro dia marcado, Am não estava com o caderno de Matemática. Quando enfim pudemos realizar a entrevista, focamos no caderno do ano anterior, também do quinto ano. Escolhemos quatro produções e, com base nelas, estabelecemos um diálogo com Am.

A primeira delas constituía-se da representação de um calendário, seguido de algumas perguntas, tais como: Quantos meses tem um ano? Quantos meses formam um bimestre? Quantos dias tem um ano? Se o ano for bissexto, quantos dias terá? Am apontou os dias da semana e os meses do ano, consultando o calendário. Não explicou, porém, o significado dos termos bimestre, trimestre e semestre e informou que o ano tinha 350 dias, o que não condiz com a quantidade de dias, nem de um ano comum nem de um ano bissexto. No caderno, todas as respostas referentes ao calendário estavam corretas; mas ao 
ser arguido a respeito delas, Am justificou que não sabia responder. Isso nos sugeriu que o participante podia ter apenas feito a correção da tarefa junto à professora, mas sem obter compreensão daquelas marcações temporais.

A segunda questão escolhida apresentava o número 632.571 e solicitava que o aluno escrevesse o número de ordens, o número de classes, o valor absoluto do algarismo 3, o valor relativo do algarismo 7, o algarismo da quinta ordem, e o algarismo da centena de milhar. Pedimos a Am que nos explicasse suas respostas, naquela atividade, e ele nos disse que não se lembrava do que fez, pois aquelas tarefas eram do ano anterior. Essa atitude nos mostrou que a relação de Am com o conhecimento veiculado pela escola tinha um caráter utilitário e imediatista, pois os conteúdos eram assimilados apenas para serem aplicados em provas, sendo, em seguida, desconsiderados.

Pedimos, ainda, que Am apontasse em seu caderno uma questão que verdadeiramente soubesse resolver. Am escolheu, então, a seguinte situação-problema: “um saco tem quinhentos limões, quantos limões há em dezoito sacos?”. Apesar de esse problema envolver uma operação de multiplicação, Am o resolveu por meio de uma subtração. Questionamos se haveria outra forma de resolver essa questão, e ele nos informou que poderíamos fazer uma adição. Essas respostas nos indicaram que Am não compreendia a lógica presente na questão, e nem mesmo a lógica do algoritmo. Não resolveu o problema da forma esperada e nem o algoritmo definido por ele.

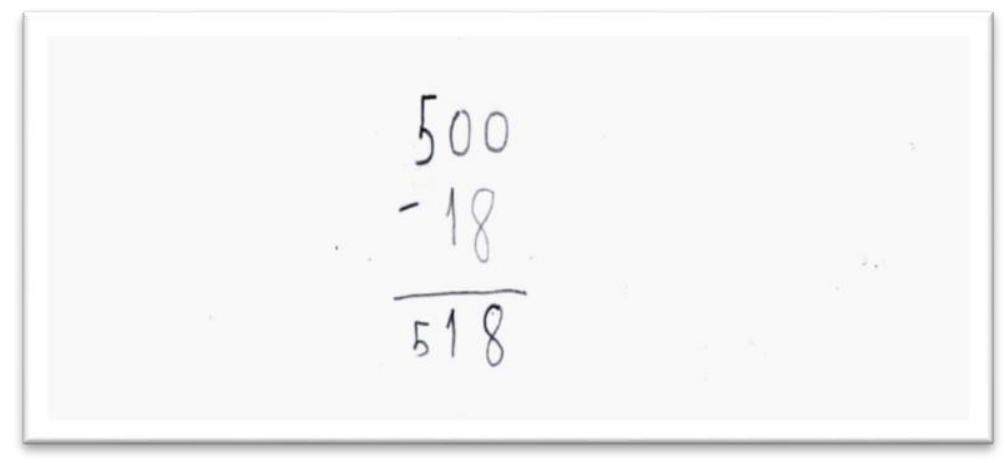

Figura 3. Resolução da questão envolvendo limões. 
Instigamos Am a falar sobre outra atividade de seu caderno, e a atividade escolhida referia-se a expressões numéricas. Nesse momento, o aluno esboçou uma explicação de como se operava aquela expressão, mostrando que deveria começar a calcular pela multiplicação. Apresentou, então, uma regra que devia ser seguida; contudo, não soube utilizá-la para resolver tal questão. O que indica que apenas memorizar regras não contribui para o sucesso na Matemática.

Logo após, questionamos se na escola era vendido lanche, e ele nos disse que apenas "picolé”. Propusemos, então, uma situação-problema com picolés, na qual Am teria que utilizar moedas. Am contou as moedas que lhe foram entregues, de forma coerente. Resolveu, por cálculos mentais, as questões: "quantos picolés poderiam ser comprados com 2 reais se cada um custasse 1 real?”; “e se custasse 50 centavos?”. No entanto, precisou recorrer à contagem com as moedas para responder, corretamente, a questão em que o picolé passou a valer 40 centavos.

Antes de finalizar a entrevista, pedimos a Am que nos desse $\mathrm{R} \$ 1,70$ de um montante de moedas totalizando $\mathrm{R} \$ 2,00$. Em três tentativas, entregou-nos $\mathrm{R} \$ 1,75$. Somente após várias contagens, instigadas pela pesquisadora, é que separou o valor que estávamos solicitando $(\mathrm{R} \$ 1,70)$. A dificuldade apresentada por Am indicou que ele precisava desenvolver o conceito de formação e decomposição dos numerais.

\subsubsection{Discussão dos dados obtidos nas entrevistas}

As respostas de Af e Am apontaram para um histórico de fracasso escolar caracterizado pela reprovação: Af no terceiro ano, e Am no quinto. Ambos demonstraram não compreender os reais motivos que os levaram a ter de refazer um ano escolar e, 
principalmente, a consequência desse fato para o desenvolvimento do seu processo de escolarização.

Ao retomar fatos dessa história, Af e Am apresentaram desempenhos opostos. Enquanto Af relatou em detalhes o que lhe foi questionado, Am se restringiu a responder "não sei”. Essa postura de Am nos fez levantar uma hipótese de que o participante se recusava a falar sobre o seu passado, em decorrência de fatos que traziam a ele más recordações.

No tocante aos interesses, observamos um aspecto comum entre os dois participantes: a motivação por atividades envolvendo tecnologia. Indicaram utilizar computador e televisão, e isso nos sugeriu a preferência por atividades prontas, ou, em outras palavras, atividades que não requeressem dos sujeitos a construção e a reelaboração de estratégias ou regras, ou seja, atividades em que a atuação deles frente ao objeto fosse passiva.

Os participantes apresentaram insatisfação com o formato atual de sua escola e manifestaram a ânsia por modificá-la. Consideraram como sendo necessárias algumas mudanças, na estrutura física, por exemplo. Af apresentou reclamações recorrentes sobre as tarefas escolares. Alegou gostar, apenas, daquelas atividades que conseguia resolver. Isso nos indicou, portanto, que a escola, por meio de suas práticas, desmotivava a participante.

Constatamos que Af e Am haviam adquirido algumas das noções básicas de tempo. Entretanto, evidenciamos dificuldades, de ambos, ao utilizar o calendário para resolver questões como: "quantos dias se passaram de uma data a outra?", indicando, assim, problemas com a habilidade matemática de contagem. Evidenciamos, ainda, que Am não compreendia o significado dos termos "bimestre", "trimestre" e "semestre". 
Já em relação às "noções de espaço", Am demonstrou ter esses aspectos mais desenvolvidos do que Af. Ele fez referência ao seu espaço próximo, como, por exemplo, sua casa, sua cidade; e demonstrou amplitude de percepção ao se referir a espaços mais distantes, como cidades pertencentes a outros estados do país. Af, no entanto, ainda estava muito centrada no seu espaço, necessitando de estratégias de intervenção que pudessem levá-la à descentração.

No contexto escolar e fora dele, percebemos, pelas respostas de Am e Af, que davam muita importância para o relacionamento com colegas. Am enfatizou que sempre era escolhido pelos colegas em uma brincadeira de rua, indicando que se sentia aceito e que seu desempenho era importante para o sucesso do grupo. Tal fato indica a importância da interação interpessoal para o desenvolvimento psicológico dos indivíduos.

As concepções de "bom aluno" foram diferentes para Af e Am. Af reproduziu a fala da professora, de que o "bom aluno" é o que participa das aulas questionando quando não entende os conteúdos. Para Am, o "bom aluno" não precisa compreender os conteúdos, basta apenas participar das aulas, sem prejudicar a ordem.

Um último dado interessante dessa primeira entrevista referiu-se à participante Af. A menina se colocou em contradição em várias ocasiões ao longo da entrevista, sem perceber, porém, essa sua condição. Em se tratando das atividades escolares favoritas, por exemplo, ora afirmava não gostar de "continhas" de Matemática, ora afirmava ser essa uma de suas tarefas prediletas.

No segundo momento da entrevista, focado no caderno e na situação com dinheiro, percebemos que ambos os participantes apresentavam dificuldades com a lógica do Sistema de Numeração Decimal. Observamos uma insistência em aplicar regras matemáticas, sem que demonstrassem a lógica subjacente a elas. 
Quanto às atividades sobre valor absoluto e valor relativo, notamos que ambos não compreendiam o significado desses dois conceitos. Sabiam aplicar as regras que lhe haviam sido ensinadas, mas não eram capazes de refletir conceitualmente sobre elas, ou seja, precisavam tomar consciência desses objetos matemáticos.

Além disso, os dados levantados junto a Af e Am, nas três questões do caderno, nos confirmaram nossa suspeita inicial. Ambos necessitavam de mediação para desenvolver a compreensão da lógica do Sistema de Numeração Decimal. Essa intervenção seria importante para que pudessem compreender as atividades que lhes vinham sendo apresentadas na sala de aula, do quinto ano, e aquelas com as quais trabalhariam nos anos subsequentes de sua escolarização.

Quanto ao sistema monetário, Am demonstrou ter um conhecimento mais desenvolvido do que Af. Ambos, no entanto, necessitavam de mediação quanto à formação dos valores. Esse fato reforçava, mais uma vez, a incompreensão da lógica do Sistema de Numeração Decimal.

Salientamos, ainda, que Af necessitava reelaborar a sua concepção em relação à Matemática e a respeito da própria competência escolar. Por diversas vezes, disse que havia errado e que precisava refazer a atividade, demonstrando ter receio de ser avaliada e fracassar.

A afirmação de Am de que não se lembrava das tarefas do caderno, pois eram do ano anterior, nos permitiu inferir que as práticas na escola ainda eram fundamentadas na reprodução de um modelo no qual o estudante adquiria conhecimentos apenas com o intuito de resolver tarefas ou questões de provas e que não lhe seriam necessários em sua aprendizagem nos anos seguintes. Essa concepção de ensino e aprendizagem que foi mediada pela escola a Am contradiz a tese de Vergnaud (2009a) de que os conceitos se desenvolvem na relação com outros conceitos. E também com as ideias de Fávero (2014) 
que em qualquer situação de ensinar e aprender existe a indicação que os conteúdos apreendidos servirão de fundamento para as aprendizagens subsequentes.

Com base nos dados expostos, salientamos a importância de dar voz aos indivíduos no contexto de uma pesquisa no campo da psicologia, para obter dados. Além disso, a apreciação das produções contidas no caderno permitiu identificar as competências e dificuldades dos indivíduos em seu processo de escolarização, e ainda serviu de base para o planejamento das sessões de intervenção junto a esses sujeitos.

\subsubsection{Dados obtidos na prova ECPN (Groupe Cimete, 1995)}

Os resultados relativos à prova ECPN (Groupe Cimete, 1995) foram descritos em duas tabelas, uma para cada sujeito. Cada uma das tabelas possui três colunas, de forma que na primeira estão descritas as situações-problemas - itens de 1 a 7 - apresentadas aos participantes. $\mathrm{Na}$ segunda, as interlocuções entre pesquisadora e os participantes. $\mathrm{Na}$ terceira coluna, apresentamos a análise para cada um dos itens da prova e evidenciamos o desempenho dos indivíduos. Na sequência dessas tabelas, apresentamos uma discussão a respeito dos resultados obtidos nessa prova, para ambos os participantes.

\subsection{Participante Af}

Tabela 6-Desempenho da participante Af na prova ECPN-(Groupe Cimete, 1995).

\begin{tabular}{|c|c|c|}
\hline Tarefas & Desempenho do sujeito & Análise \\
\hline $\begin{array}{l}\text { Item 01 - Descrever a situação } \\
\text { "Aqui está a galinha, o cachorro } \\
\text { e o coelho. Eu gostaria que você } \\
\text { me dissesse o que está vendo } \\
\text { aqui". }\end{array}$ & $\begin{array}{l}\text { Af - Não sei. @ } \\
\mathrm{P} \text { - Então vamos tentar } \\
\text { descobrir? ...você sabe que bicho é } \\
\text { esse? } \\
\text { Af - Uma galinha. } \\
\mathrm{P} \text { - E esse? }\end{array}$ & $\begin{array}{l}\text { Não desmembrou as coleções e } \\
\text { fez referência às quantidades de } \\
\text { cada um após solicitação da } \\
\text { experimentadora. } \\
\text { Por meio da estimativa visual } \\
\text { global identificou as quantidades }\end{array}$ \\
\hline $\begin{array}{l}\text { Quantidades de fichas de cada } \\
\text { um: } \\
\text { Galinha (2) } \\
\text { Cachorro (3) } \\
\text { Coelho (7) }\end{array}$ & $\begin{array}{l}\text { Af - Um cachorro. } \\
\mathrm{P}-\text { E esse? } \\
\text { Af - Coelho. } \\
\mathrm{P}-\text { Eu queria que você me dissesse } \\
\text { o que você está vendo aqui. }\end{array}$ & $\begin{array}{l}\text { de duas fichas e três fichas. Ao } \\
\text { identificar a quantidade de fichas } \\
\text { do coelho, que era igual a sete } \\
\text { fichas, respondeu seis. Reviu sua } \\
\text { resposta ao ser indagada pela }\end{array}$ \\
\hline
\end{tabular}




\begin{tabular}{|c|c|}
\hline & $\begin{array}{l}\text { Af - Botões. } \\
\text { P - Que mais? } \\
\text { Af - Animais. } \\
\text { P - Que animais? O que você pode } \\
\text { falar dos animais e dos botões } \\
\text { juntos? } \\
\text { Af - (?) } \\
\text { P - Olha, descreve pra mim, o que } \\
\text { você está vendo aqui. } \\
\text { Af - OS ANIMAIS! } \\
P \text { - CERTO Olha só, está é a } \\
\text { galinha e ela tem duas fichinhas, } \\
\text { este é o senhor cachorro e ele tem... } \\
\text { Af - Três. } \\
P \text { - E aquele ali é o senhor... } \\
\text { Af - Coelho. } \\
\text { P - E ele tem quantas fichas? } \\
\text { Af - Seis. } \\
\text { P - Ah? } \\
\text { Af - Sete. }\end{array}$ \\
\hline $\begin{array}{l}\text { Item } 02 \text { - Quem tem mais? } \\
\text { "Quem tem mais fichas? Como } \\
\text { você sabe? } \\
\text { Quantidades de fichas de cada } \\
\text { um: } \\
\text { Galinha (2) } \\
\text { Cachorro (3) } \\
\text { Coelho (7) }\end{array}$ & $\begin{array}{l}\mathrm{P}-\text { Qual deles tem mais fichas? } \\
\text { Af - O coelho. } \\
\mathrm{P} \text { - O coelho? Como é que você } \\
\text { descobriu isso? } \\
\text { Af - Ah, contando. } \\
\mathrm{P} \text { - Como que você fez a contagem } \\
\text { para descobrir que ele tem mais? } \\
\text { Af - Eu contei quatro e juntei com } \\
\text { esses três. } \\
\mathrm{P} \text { - E o total é? } \\
\text { Af - Sete. } \\
\mathrm{P} \text { - Você pode me dizer quanto que } \\
\text { cada um tem? } \\
\text { Af - Junto? } \\
\mathrm{P} \text { - Primeiramente separado. } \\
\text { Af - Ele tem } 2 \text {, ele tem três e ele } \\
\text { tem } 7 . \\
\mathrm{P} \text { - Não, não, diz pra mim assim: a } \\
\text { galinha tem... só pra eu saber de } \\
\text { quem você tá falando. } \\
\text { Af - A galinha tem } 2 \text {, o cachorro } \\
\text { tem } 3 \text { e o coelho } 7 .\end{array}$ \\
\hline $\begin{array}{l}\text { Item } \mathbf{0 3} \text { - Todos parecidos } \\
\text { "O que podemos fazer para que } \\
\text { todos tenham a mesma } \\
\text { quantidade de fichas?” } \\
\text { Quantidades de fichas de cada } \\
\text { um: } \\
\text { Galinha (2) } \\
\text { Cachorro (3) } \\
\text { Coelho ( } 7 \text { ) } \\
\text { Qualquer que seja a resposta do } \\
\text { sujeito e sobretudo no caso de } \\
\text { sucesso, } 2 \text { saídas são propostas } \\
\text { para incitá-lo a mudar a } \\
\text { estratégia. }\end{array}$ & $\begin{array}{l}\text { P - Faça alguma coisa para que } \\
\text { todos tenham a mesma quantidade. } \\
\text { Af - (.19) \{Af manipula as fichas\} } \\
\text { P - O que você fez? } \\
\text { Af - Eu botei um dele pra cá. } \\
\text { P - Dele quem? } \\
\text { Af - Do cachorro para a galinha. Aí } \\
\text { eu passei dois do coelho pra cá. } \\
\text { P - E aí cada um ficou com quanto? } \\
\text { Af - Quatro. } \\
\text { P - Muito bem. Você pode fazer } \\
\text { isso diferente? } \\
\text { Af - Posso. } \\
\text { P - Como? } \\
\text { Situação atual: galinha (4), } \\
\text { cachorro (4), coelho (4). }\end{array}$ \\
\hline
\end{tabular}

experimentadora. Af informou a quantidade de fichas de cada um, utilizando as palavras número.

Af disse que contou quatro, mas não informou o procedimento utilizado nessa contagem.

Realizou uma adição por meio de cálculo mental, $(4+3)$, para encontrar o resultado de qual dos animais tinha mais.

Identificou as quantidades sem recorrer a contagem termo a termo.

Na primeira resolução Af realizou uma compensação, retirando de um e passando para os outros. $\mathrm{Na}$ segunda, retirou um elemento de cada um e os igualou. 
Item 04 - "A mais que" a partir de estados iniciais diferentes (de um conjunto) e a partir de estados iniciais idênticos. Quantidades de fichas de cada um:

Galinha (3)

Cachorro (0)

Coelho (7)

"Faça alguma coisa para que o cachorro tenha quatro a mais que a galinha".

"Faça alguma coisa para que o cachorro tenha uma a mais que o gato".
Af - - realiza a mudança $\}$

Af - Eu tirei um de cada um.

$\mathrm{P}-\mathrm{E}$ aí cada um ficou com

quantos?

Af - Três.

$\mathrm{P}$ - Mas todos têm a mesma

quantidade?

Af - AHÃ !

Situação atual: galinha (3),

cachorro (3), coelho (3).

P - Agora, Af, eu vou fazer o seguinte. Esse aqui tem três eu vou deixar com três, o cachorro não vai ficar com nada: e o coelho. Quanto que ficou lá no coelho?

Af - Três...NÃO sete!

$\mathrm{P}$ - Eu quero você faça alguma

coisa para que o cachorro tenha quatro fichas a mais que a galinha.

Af - Hum?

$\mathrm{P}$ - O cachorro agora não tem nada, a galinha tem três. Eu quero que você faça alguma coisa para que o cachorro, passe a ter quatro (...) A MAIS que a galinha.

Af - (.5) \{modifica as fichas em silêncio

$\mathrm{P}$ - Ali tem quatro a mais que aqui?

Af $-\{$ Continua movimentando as fichas $\}$

$\mathrm{P}-\mathrm{E}$ agora? Ali tem quantos?

Af - (.6)

$\mathrm{P}$ - Ali tem quantos? Vai descobre.

Af - (.10) Três.

$\mathrm{P}-\mathrm{Hã}$ ?

Af - NÃO, OU SETE!

$\mathrm{P}$ - Então o cachorro tendo sete, ele vai ter quatro a mais que a galinha que tem três?

Af - Hum, hum.

$\mathrm{P}$ - O que você fez Af para chegar a esse resultado?

Af - Tirei todos do coelho.

$\mathrm{P}-\mathrm{E}$ passou para o cachorro?

Af - \{ acena positivamente com a

cabeça $\}$

Situação atual: galinha (3), cachorro (7), coelho (0).

$\mathrm{P}$ - Agora, eu quero que o cachorro só tenha uma ficha a mais que a galinha.

Af $-\{$ modificou as fichas $\}$

$\mathrm{P}-\mathrm{E}$ agora, o que você fez?

Af - Peraí

$\mathrm{P}$ - Você tinha trazido um do cachorro pra galinha.

Af - (.10)

$\mathrm{P}$ - Me explica agora a quantidade que cada um tem e o que você fez.
Manteve a quantidade inicial de fichas da galinha, transferiu para o cachorro todas as fichas do coelho.
Transferiu 3 fichas do cachorro para o coelho deixando o cachorro com 4 , isto é, uma a mais que a galinha possuía
Nesse momento Af acrescentou 3 fichas à quantidade inicial do cachorro que era de 4 . Ficando o cachorro com sete fichas. 
Item 5 - "Mais que" com "logro" numérico (aquilo que é dado como diferença não corresponde ao ajuntamento pedido)

Quantidades de fichas de cada um:

Galinha (4)

Cachorro (7)

Coelho (7)
Af - A galinha tem três e o cachorro tem quatro. Eu tirei o três que o cachorro tinha e passei lá pro coelho.

P - Deu para o coelho né. E agora, o cachorro tem um a mais que a galinha?

Af - Hum hum.

Situação atual: galinha (3), cachorro (4), coelho (3).

$\mathrm{P}$ - Af, agora você vai dar três fichas a mais para o cachorro do que para a galinha.

Af $-\{$ modifica as fichas $\}$

$\mathrm{P}-\mathrm{E}$ aí o que você fez? Porque você tirou três e botou um? Af - Porque se eu tirasse três ia ficar três como a galinha, por isso eu botei três aqui.

$\mathrm{P}$ - Opa, você falou rápido demais e eu não te acompanhei.

Af - Se eu tirasse três ficaria igual a galinha.

$\mathrm{P}$ - Isso.

Af - E aí você pediu para colocar três a mais, aí eu botei três.

$\mathrm{P}$ - Ah. Sim agora o cachorro

passou a ter três a mais.

Situação atual: galinha (4),

cachorro (7), coelho (6).

P - Agora, a galinha vai ter quatro o cachorro vai ter sete e o coelho também. Conta para mim se tem sete aí.

Af $-\{$ realiza a contagem

visualmente, sem tocar nas fichas $\}$.

$\mathrm{P}$ - Tinha uma a mais?

Af - Hum, hum.

$\mathrm{P}$ - Olha só, o coelho precisa ter cinco a mais que a galinha.

Af - (.5) cinco a mais?

$\mathrm{P}-\mathrm{E}$ aí?

Af - O quê?

$\mathrm{P}-\mathrm{O}$ que você fez?

Af - Eu tirei cinco do cachorrinho

e ...

$\mathrm{P}-$ E lá ficou com quantos? $\{\mathrm{No}$ coelho\}

Af - Doze.

$\mathrm{P}-\mathrm{E}$ você acha que doze são cinco a mais que quatro que é o que a galinha tem?

Af - Sim. Porque o coelho tinha sete.

$\mathrm{P}-\mathrm{Ah}$.

Af - Por que o coelho tinha sete. E a galinha, tem quatro. Então o coelho vai ter cinco a mais que a galinha.
Retirou cinco fichas das sete do cachorro e as deu ao coelho. Logo, juntou à quantidade inicial do coelho que era sete, o número anunciado pela experimentadora: cinco. Em outras palavras, Af entendeu que era para acrescentar mais cinco na quantidade inicial. 
Item 6 - Pesquisa do estado inicial (escondemos na mão fechada 3 fichas)

"Eu escondi algumas fichas na mão e vamos descobrir juntas quantas eu escondi”.

(A experimentadora vai acrescentando 4 fichas na mão fechada que contém as outras 3 fichas)

Item 7 - Transformação negativa

"Eu fiz uma coisa que você não viu, e agora eu tenho 3 fichas na minha mão. O que eu fiz?"

Cinco fichas foram colocadas em uma mão e convidamos a participante a contar. Em seguida retiramos três sem que ela visse.
P - Af, vamos ver se você é boa em ser detetive. Eu tenho algumas fichas escondidas aqui, e eu vou colocando algumas fichas na minha mão e você vai contar quantas fichas eu vou colocando. Está bom? Af - (.7)

$\mathrm{P}$ - Uma, duas, três, quatro. Agora eu tenho além dessas quatro fichas aqui, mais aquelas que eu já tinha. E aí eu formei esse tanto aqui. \{Pesquisadora abre a mão e mostra para Af a quantidade \} quantas fichas você acha que eu tinha no começo.

Af - Três!

$\mathrm{P}$ - Por que você acha que é três.

Af - Você botou quatro não foi?

$\mathrm{P}-$ Foi.

Af - Três.

$\mathrm{P}$ - Por que três?

Af - Por que se você tirar quatro fica três.

$\mathrm{P}$ - Você me descobriu. Vou fazer de novo. Eu coloquei uma quantidade e agora eu vou colocar outra. Vamos lá?

Af - Um, dois, três, quatro.

$\mathrm{P}$ - Eu tenho na minha mão nove fichas.

Af - Abre a mão.

P - Não::: @@dessa vez eu vou

fazer diferente. Eu tenho nove

fichas e a gente colocou quatro.

Quantas fichas eu tinha no início?

Af - Cinco.

$\mathrm{P}$ - Por que Af?

Af - Por que se eu tirar quatro de nove fica cinco.

$\mathrm{P}$ - Ai. Você adivinhou de novo.

Vou tentar fazer outra pra você não descobrir. Vamos ver se você descobre essa daqui.

Af - EU SOU BOA!

$\mathrm{P}-$ É eu estou vendo. Olha só.

Conta comigo.

Af - Um, dois, três, quatro, cinco. $\mathrm{P}$ - Escondi. Agora, eu só tenho três fichas aqui. $\mathrm{O}$ que eu fiz. Af - Você tirou duas.

$\mathrm{P}$ - Ah, Af, vou fazer mais uma, por que eu me recuso acreditar que eu perdi todas. @@vamos lá, conta quantos tem.

Af - Um, dois, três, quatro, cinco, seis, sete, oito, nove, dez.

$\mathrm{P}$ - Agora eu só tenho sete. $\mathrm{O}$ que eu fiz?
A pesquisadora cometeu um equívoco, pois abriu a mão e pediu para Af dar a resposta, quando na verdade deveria ter esperado a resposta de Af para aí sim abrir a mão.

Af identificou o estado final de uma transformação por soma, por meio de uma estimativa global com verificação do resultado.

Numa segunda tentativa a experimentadora não abriu a mão. Porém isso não prejudicou Af, que informou corretamente que ao retirar quatro da quantidade final que era nove, o resultado inicial seria 5 .

Af identificou a quantidade final em ambas as situações que lhe foram propostas. Pela estimativa global informou primeiramente que a pesquisadora havia retirado duas fichas da quantidade inicial que era cinco. Na sequência diz que foi retirado três da quantidade inicial que era dez. Nas duas sequências Af se limitou a responder sem verificar suas respostas. 
Af - Você tirou três.

$\mathrm{P}$ - Ah, não, olha, desta vez eu

perdi todas e você só ganhou.

Af - @@@@@

P - Você é muito esperta. Me

colocou para trás. Vamos ver se na

outra eu ganho de você.

Af - Não, não,não. @@@@.

\subsection{Participante Am}

Tabela 7 - Desempenho do participante Am na prova ECPN-Cimete (1995).

\begin{tabular}{|c|c|c|}
\hline Tarefas & Desempenho do sujeito & Análise \\
\hline $\begin{array}{l}\text { Item } 01 \text { - Descrever a } \\
\text { situação } \\
\text { “Aqui está a galinha, o } \\
\text { cachorro e o coelho. Eu } \\
\text { gostaria de que você me } \\
\text { dissesse o que está vendo } \\
\text { aqui'. } \\
\text { Quantidades de fichas de } \\
\text { cada um: } \\
\text { Galinha (2) } \\
\text { Cachorro (3) } \\
\text { Coelho (7) }\end{array}$ & $\begin{array}{l}\mathrm{P}-\mathrm{E} \text { aí? O que você está vendo aí? } \\
\text { Am - Um cachorro, um coelhinho e uma } \\
\text { galinha. } \\
\mathrm{P} \text { - O que você pode me dizer do que você } \\
\text { está vendo aqui? } \\
\text { Am - Eu estou vendo um coelho, com uns } \\
\text { botõezinhos aqui. } \\
\mathrm{P} \text { - Sim. } \\
\text { Am - Um cachorro com uns botõezinhos, } \\
\text { mas só que aqui tem mais, aqui tem menos e } \\
\text { aqui tem menos. \{Comparando as } \\
\text { quantidades do coelho, cachorro e galinha\} }\end{array}$ & $\begin{array}{l}\text { Am desmembrou a coleção de } \\
\text { animais, relacionou os animais } \\
\text { às quantidades de ficha de cada } \\
\text { uma espontaneamente. Am } \\
\text { informou a quantidade de } \\
\text { fichas de cada um utilizando as } \\
\text { palavras número. Fez uso } \\
\text { consciente dos conceitos de } \\
\text { mais e menos quando se referiu } \\
\text { a quantidade de fichas de cada } \\
\text { animal. }\end{array}$ \\
\hline $\begin{array}{l}\text { Item } 02 \text { - Quem tem } \\
\text { mais? } \\
\text { "Quem tem mais fichas?" } \\
\text { "Como você sabe?" } \\
\text { Quantidades de fichas de } \\
\text { cada um: } \\
\text { Galinha (2) } \\
\text { Cachorro (3) } \\
\text { Coelho (7) }\end{array}$ & $\begin{array}{l}\mathrm{P} \text { - Isso. Quem que tem mais? } \\
\text { Am - Esse. } \\
\mathrm{P} \text { - Esse é quem é esse? } \\
\text { Am - O coelho. } \\
\mathrm{P} \text { - E quem que tem menos? } \\
\text { Am - Menos? É a galinha. } \\
\mathrm{P} \text { - E como você descobriu isso? } \\
\text { Am - Eu percebi. } \\
\mathrm{P} \text { - Mas como? Você percebeu de alguma } \\
\text { forma. } \\
\text { Am - Ahã! } \\
\mathrm{P} \text { - O que você fez para perceber que um } \\
\text { tinha mais o outro tinha menos e ou outro } \\
\text { tinha menos ainda. } \\
\text { Am - Por eu vi que aqui tem mais } \\
\text { botãozinho e eu vi que aqui tem mais, aqui } \\
\text { tem um pouquinho e aqui tem um. } \\
\mathrm{P} \text { - Tá. Você descobriu isso olhando? } \\
\text { Am - Hum, hum. } \\
\mathrm{P} \text { - Mas você sabe a quantidade que tem? } \\
\text { Am - Eu só sei que esse daqui tem quatro e } \\
\text { esse daqui tem dois. } \\
\mathrm{P}-\mathrm{E} \text { lá? } \\
\text { Am - Aqui tem seis. NÃO, sete. } \\
\mathrm{P} \text { - Sete! Tá certo. Já que você disse que um } \\
\text { tem mais, o outro tem menos eu vou fazer }\end{array}$ & $\begin{array}{l}\text { Primeiramente, informou quem } \\
\text { tinha mais com base no espaço } \\
\text { ocupado pelas fichas. } \\
\text { E para tal fim fez uso dos } \\
\text { termos mais, menos, menos } \\
\text { ainda. } \\
\text { Em seguida indicou as } \\
\text { quantidades utilizando palavra } \\
\text { número, com base na } \\
\text { estimativa visual global, sem } \\
\text { realizar a contagem termo a } \\
\text { termo. }\end{array}$ \\
\hline
\end{tabular}




\author{
Item 03 - Todos \\ parecidos \\ "O que podemos fazer \\ para que todos tenham a \\ mesma quantidade de \\ fichas?" \\ Quantidades de fichas de \\ cada um: \\ Galinha (2) \\ Cachorro (3) \\ Coelho (7)
}

Qualquer que seja a resposta do sujeito e sobretudo no caso de sucesso, 2 saídas são propostas para incitá-lo a mudar a estratégia. uma coisa aqui pra você. Esse daqui vai passar a ter (?) lá já tem sete né?

Am - É

$\mathrm{P}$ - Me diz quanto cada um deles tem agora.

Am - Aqui tem sete, três e dois.

$\mathrm{P}$ - Eu quero que você faça alguma coisa para que eles todos tenham a mesma quantidade. Você pode fazer como você quiser.

Am - Com esses botões aqui? $\mathrm{P}$ - Pode ser com esses, do jeito que você quiser. O que eu quero é que eles tenham a mesma quantidade. Que a galinha, o cachorro e o coelho tenham o mesmo tanto. Am - O mesmo tanto? Deixa eu ver. \{sussurra a contagem . Todos têm sete. $\mathrm{P}$ - Agora sim, todos têm sete? O que você fez.

Am - Eu peguei mais botão que precisava pra ter a quantidade desse aqui.

$\mathrm{P}$ - Tá bom. Você pode fazer de uma forma diferente?

Am - Hum..

$\mathrm{P}$ - Então faz pra mim.

Am - Deixa eu tirar aqui (?)

$\mathrm{P}$ - Detalhe a mesma quantidade em todos

Am - A mesma quantidade? Em todo que tá aqui.

$\mathrm{P}$ - É, você pode escolher, e não

necessariamente todos têm que ter sete, eu quero que todos tenham a mesma

quantidade. A quantidade que você escolher, todo mundo vai ter que ter a mesma.

Am - Hum hum. Deixa eu ver aqui.

$\{$ Manuseia as fichas

$\mathrm{P}-\mathrm{O}$ quê que você fez?

Am - Pronto. Porque eu tirei um daqui, um daqui, e não tirei um daqui. Ai deu quatro.

$\mathrm{P}$ - Então agora, todos têm a mesma quantidade?

Am - Ahã!

$\mathrm{P}$ - Por que todos têm a mesma quantidade? AM: Porque eu tirei... por que... a peça que eu peguei... os cinco... parece... eu pus aqui. Aí eu deixei uns e peguei, tirei um daqui e ficou três, tirei outro daqui, que ficou três e aqui só tinha dois, aí eu deixei e fiquei com um assim.

P: Então, no final, todo mundo ficou com quatro?

AM: Hum hum.

Item 04 - "A mais que" a partir de estados iniciais diferentes (de um conjunto) e a partir de estados iniciais idênticos. Quantidades de fichas de cada um:
P - Quanto que eles têm agora? AM: Agora? O coelho tem sete. O cachorro não tem nenhum e a galinha tem três.

P: Muito bem! Eu quero agora que você faça alguma coisa para que o cachorro passe a ter

AM: Quatro? quatro a mais do que a galinha.
O participante resolveu a questão de duas maneiras. $\mathrm{Na}$ primeira igualou todas as quantidades apanhando peças de uma reserva. Na segunda retirou as quantidades que ultrapassavam e as devolveu para a caixa-reserva. Essa questão mostra que Am sabia operar mentalmente cálculos envolvendo pequenas quantidades.
Manteve a quantidade inicial de fichas da galinha, transferiu para o cachorro todas as fichas do coelho. 


\section{Galinha (3) \\ Cachorro (0) \\ Coelho (7)}

"Faça alguma coisa para que o cachorro tenha quatro a mais que a galinha".

"Faça alguma coisa para que o cachorro tenha uma a mais que o gato".
P: A mais!

AM: A mais...

P: Tenha quatro a mais do que a galinha!

AM: Aqui!

P: Ele tem quantos?

AM: Quatro.

$\mathrm{P}$ : Ele tem quatro a mais que a galinha? Ele tem o que agora?

AM: Oito?

P: Oito?

AM: Hum hum.

P: E agora passou a ter quatro a mais do que a galinha?

AM: Hum hum.

P: Por quê?

AM: Ah...

P: Como é que você descobre que um tem quantidade maior que o outro?

AM: Por causa da quantidade.

$\mathrm{P}$ : O que você fez para chegar ao número oito?

AM: Pegando quatro de quatro. Pegando

oito!

P: Aqui tem quantos? \{Apontando para a galinha\}

AM: Três.

$\mathrm{P}$ : Se eu colocar mais quatro eu vou ter quantos?

AM: E... se você botar mais quatro aí?

P: É. Mais quatro!

AM: Sete!

P: Sete?

AM: É.

P: E se eu disser que o cachorro tem quatro a mais do que a galinha, ele tem que ter oito?

AM: Não! Tem que ter quatro!

Situação atual: galinha (3), cachorro (8), coelho (4).

P: Então vamos fazer outro! Faz alguma coisa para que o cachorro tenha apenas um a mais do que a galinha. Ele só pode ter uma a mais!

AM: Um a mais que a galinha eu não consigo não!

P: Quantos que ele tem aí?

AM: Só um.

P: Só um. Quem tem mais: a galinha ou o cachorro?

AM: A galinha.

P: A galinha! Eu quero que o cachorro tenha um a mais. Só que é um a mais em comparação à galinha!

Am: manuseia as fichas.

P: Agora o cachorro tem quantas?

AM: Só duas!

P: E a galinha tem quantos?

AM: Três.

P: Quem tem a mais que o outro? AM: A galinha.
Am deu oito fichas para o cachorro, acreditando que assim estava colocando quatro a mais que a galinha, que tinha 3
Inicialmente indicou compreender o conceito "mais que", mesmo que tenha efetuado incorretamente a situação de que o cachorro deveria ter 1 a mais que a galinha. Soube dizer que os três da galinha significavam um a mais que o cachorro.
Confundiu "a mais que" com a quantidade de fichas da galinha. 
P: Por quê?

AM: Porque tem três!

$\mathrm{P}$ : E o cachorro tem quantas?

AM: Duas!

P: Quantos que a galinha tem a mais?

AM: Três.

P: Qual é quantidade que a galinha tem a mais que o cachorro?

AM: A mais? Seis. Nove?

Situação atual: galinha (3), cachorro (2), coelho (4).

P: Não. Faz alguma coisa aí para que o cachorro fique com três a mais que a galinha. Vamos fazer diferente? Põe aqui a mesma quantidade para o cachorro que a galinha tem. Agora eu quero que o cachorro tenha três a mais que a galinha.

AM: Três a mais? \{Manuseia as fichas e as modifica de lugar\}

P: E agora, o que você teve que fazer?

AM: É... que eu peguei mais botão.

P: Tá. Você pegou mais botão, mas por quê?

AM: Porque tem que ter mais.

P: Eles dois tinham a mesma quantidade, aqui tinha três, aqui tinha três. Aí eu falei para você: "eu quero três a mais". Aí você fez o quê?

AM: Aí eu fiz mais três.

P: Mais três! Exatamente! Agora, eu vou tirar esse aqui, o cachorro vai ficar com dois. Eu quero que você dê para o cachorro um a mais que a galinha.

AM: É... Eu pus só mais um... Não!

P: Nossa, você fez assim: Não! Por que você fez "Não"?

AM: Porque eu tinha errado.

P: Porque você errou?

AM: Porque...

P: O que você está pensando? Diz para mim! Veja se eu posso te ajudar.

AM: Esse aqui eu não sei... Acho que só dá três.

Item 5 - "Mais que" com "logro" numérico (aquilo que é dado como diferença não corresponde ao ajuntamento pedido) Quantidades de fichas de cada um:

Galinha (4)

Cachorro (7)

Coelho (7) AM: Tem dez.
P: Tudo bem! Então agora vamos fazer diferente. Eu vou dar quatro para a galinha, o cachorro vai ganhar sete e o coelho também sete. Eu quero agora que o coelho tenha cinco a mais que a galinha

AM: Cinco a mais?

P: É

Am: (.35)

P: Espera aí... Deixa eu ver quanto é que ficou aqui! Conta aí para mim quantos tem!

P: Por que agora tem dez?

AM: Não! Tem dez não! Tem um, dois, três, quatro, cinco, seis, sete, oito \{ sussurrando contagem $\}$... doze.

P: O que você fez?

AM: Eu pus mais cinco.
A ação e argumentação de Am confirmam que não compreendia o termo a mais que. Ele adicionou mais três.
Realizou contagem termo a termo e acrescentou cinco quando lhe foi pedido para fazer algo que deixasse o coelho com cinco fichas a mais que a galinha. 
P: Você pôs mais cinco?

AM: Hum hum.

Item 6 - Pesquisa do estado inicial (escondemos na mão fechada 3 fichas)

"Eu escondi algumas fichas na mão e vamos descobrir juntas quantas eu escondi".

(A experimentadora vai acrescentando 4 fichas na mão fechada que contém as outras 3 fichas)

Item 7 - Transformação negativa

"Eu fiz uma coisa que você não viu, e agora eu tenho 3 fichas na minha mão. O que eu fiz?"

Cinco fichas foram colocadas em uma mão e convidamos a participante a contar. Em seguida retiramos três sem que ela visse.
P: Perfeito! Agora... Eu tenho aqui na minha mão, algumas fichas que eu escondi. Eu vou começar a acrescentar outras e você vai contar junto comigo. Pode ser? Aqui já tem ficha! Está bom? Mas você vai contar comigo essas aqui! Quantas eu estou colocando?

AM: Uma, duas, três, quatro...

P: Quatro! Lembra que eu falei que na minha mão tinha outras fichas antes? E agora, a gente colocou quantas?

AM: Quatro.

P: Quatro. A partir desse momento eu passei a ter sete fichas. E aí, eu quero que você descubra quantas fichas eu tinha antes de colocar aquelas quatro.

AM: Hum... Agora tem sete?

P: Agora eu tenho sete! Depois que a gente colocou as outras quatro.

AM: Tinha três!

P: Como é que você descobriu isso?!!!

AM: Hum...

P: Como é que você descobriu?

AM: Eu contei!

P: Você contou como? Eu quero só que você me explique como você contou.

AM: Assim: Agora tem sete, aí tirou quatro e deixou três!

P - Vou fazer uma outra, pode ser?

\{Am acena positivamente com a cabeça $\}$.

P - Então, olha só. Conta para mim quantas fichas eu tenho aqui agora!

AM: Cinco.

P: Cinco, é? E... agora eu só tenho três. Eu tinha cinco e agora só tenho três. $\mathrm{O}$ que eu fiz?

AM: Você tirou duas!

P: Ah, você está muito esperto! Acabou minhabrincadeira!@@@@

Am-@@@@

P - Quer dizer que eu tirei duas? Vou fazer outra, tá? A gente vai colocar... quantos têm aí?

AM: Aqui?

P: É.

AM: Um, dois, três, quatro, cinco, seis, sete, oito.

P: Agora eu tenho cinco. O que eu fiz?

AM: Você .... Tu tem cinco? Você tirou três!
Am identifica a transformação da quantidade inicial a partir da inserção de mais fichas. Afirma ter contado para chegar ao número que informou para a pesquisadora. Ou seja, realizou mentalmente o cálculo da subtração 7-4.

Realizou a contagem da quantidade inicial, cinco, apenas por estimativa visual global, sem contar termo a termo.

Realizou contagem termo a termo na quantidade oito. Informou que fez uma subtração $(5-3=2)$ para encontrar o resultado final da transformação. Os resultados dessa questão repetem os resultados da questão anterior, a respeito de Am resolver cálculos mentais de pequenas quantidades. 


\subsubsection{Discussão dos dados obtidos na segunda etapa da primeira fase da coleta} de dados: a avaliação das competências e dificuldades matemáticas

Os resultados da prova ECPN (Groupe Cimete, 1995) indicaram que, em geral, Am e Af demonstraram ter adquirido alguns conceitos e funções elementares do número, como, por exemplo, contagem termo a termo, cardinalização, comparação, igualdade e pesquisa do estado inicial e suas transformações. Os participantes da pesquisa mostraram, contudo, dificuldades na quantificação de ordem "mais que".

No item 1 da prova, ambos os participantes fizeram uso de palavras-número para identificar as quantidades de fichas dos animais que lhes foram apresentados. Am desmembrou a coleção de animais espontaneamente. Af não desmembrou a coleção e fez uso da estimativa global para informar a quantidade de fichas de cada animal. Af somente apontou essa quantidade após solicitação da pesquisadora.

No item 2 da prova, relacionado à comparação entre as quantidades, e cujo objetivo era apontar qual dos animais teria mais fichas que os outros, Af realizou um cálculo mental (4+3). Am se atentou para o espaço ocupado pelas fichas dos três animais (galinha, cachorro e coelho); e, utilizando os termos mais, menos e menos ainda, informou qual deles tinha mais fichas que os outros. Evidenciamos, assim, que os sujeitos possuíam a competência de partir de uma determinada quantidade de fichas e adicionar outra quantidade chegando a um novo resultado.

No item 3, em que era pedido que todos os animais ficassem com a mesma quantidade de fichas, identificamos três estratégias de resolução. A primeira delas foi utilizada tanto por Af quanto por Am. Eles igualaram as quantidades dos três animais recorrendo às fichas da caixa-reserva. A segunda estratégia identificada consistiu na compensação das quantidades entre os animais, ou seja, os três animais ficaram com a 
mesma quantidade sem ter de recorrer às fichas da caixa-reserva. A terceira estratégia se baseou na retirada de fichas que ultrapassavam. Ou seja, o participante decidiu que todos teriam uma quantidade $\mathrm{N}$, e o restante foi devolvido à caixa-reserva.

Os itens 4 e 5 da prova tinham como objetivo avaliar a forma como os participantes se relacionavam com a questão " $\mathrm{N}$ a mais que". Vimos que a compreensão desse conceito ainda estava incipiente em ambos os participantes. Souberam indicar onde havia maior quantidade de fichas, mas quando solicitados a operar de forma que alguém passasse a ter uma quantidade "a mais que", lançavam mão da estratégia de acrescentar, desconsiderando a quantidade inicial.

O desempenho dos participantes nos itens 6 e 7 da prova revelou que eles identificaram o estado inicial e o estado final de uma dada quantia, considerando as transformações (inserção e/ou retirada de quantias). Na questão 6, informaram as quantidades iniciais de fichas por meio da retirada (7-4 e 9-4). Am disse que havia contando para chegar ao resultado, mas ao explicar o seu procedimento se referiu a uma subtração. Na questão 7, novamente realizaram uma subtração, e o desempenho foi análogo ao da questão 6 .

A aplicação dessa prova nos mostrou que os sujeitos Af e Am já haviam construído algumas das noções elementares do conceito de número, no entanto, necessitavam desenvolver novas competências que permitissem reelaborar os conceitos relacionados à quantificação de ordem, principalmente os que se referem à noção "mais que". Diante disso, e conforme a dificuldade apresentada pelos participantes nas questões 4 e 5 da prova, em relação à inserção de quantidades a mais em uma quantidade inicial, justifica-se a intervenção psicopedagógica. Lembramos, contudo, como afirmamos anteriormente, que Am e Af apresentaram dificuldades quanto à lógica do Sistema de Numeração Decimal. Baseados nos dados de toda a primeira fase de coleta de dados, tecemos uma discussão no 
próximo item abarcando os resultados gerais desta primeira fase da pesquisa. Além disso, apontamos o nosso fundamento para a próxima parte: a intervenção psicopedagógica.

\subsubsection{Discussão geral da primeira fase da coleta de dados: o fundamento para a}

\section{intervenção psicopedagógica}

Como dissemos anteriormente, a primeira fase de coleta de dados da pesquisa se constituiu de duas etapas: entrevista e Prova ECPN (Groupe Cimete, 1995). As informações obtidas na primeira etapa evidenciaram que a principal dificuldade de Af e Am, na Matemática, naquele momento, dizia respeito à incompreensão da lógica do Sistema de Numeração Decimal (SND) e suas operações, além de dificuldades com a leitura de tempo. Os participantes apresentavam dificuldades na aquisição e no uso de conceitos fundamentais como: uso do sistema posicional e do numeral zero, valor relativo e valor absoluto, composição e decomposição de numerais, formação e decomposição de valores do sistema monetário e contagem dos dias no calendário.

Na resolução de algoritmos, observamos que os participantes recorreram ao uso de material concreto para resolver cálculos que envolviam, por exemplo, números múltiplos de 3 e 4. Em operações com números múltiplos de 5, Af e Am, operaram por cálculo mental, sem recorrer ao material concreto e, em alguns momentos, nem mesmo realizavam registros de cálculos no papel. Esse dado não confirmou, porém, que possuíssem a compreensão das operações ligadas ao número 5, ou mesmo do algoritmo da multiplicação. Poderíamos supor que estavam manipulando fatos da tabuada de multiplicação do numeral 5 apenas por que haviam memorizado a tabuada. Assim, o dado obtido, e que se relaciona aos dados citados no parágrafo anterior, é que, ambos, operavam algoritmos de forma mecânica sem compreender a lógica subjacente a eles. 
Quanto à noção de espaço, identificamos que a participante Af necessitava ampliar essa noção. Justificamos esse dado pela forma limitada (referência apenas a localizações próximas de sua residência) e pouco detalhada como respondeu as perguntadas relativas ao seu trajeto de casa para a escola. Am, por sua vez, mostrou-se competente para descrever trajetos e localizar-se no espaço, seja em sua cidade ou em outras regiões mais distantes.

Quanto às noções de tempo, ambos apresentaram dificuldades no uso do calendário, principalmente no que se refere à contagem dos dias no calendário. Esse dado revelou dificuldades com a contagem de grandes quantidades, pois, em relação à contagem de pequenas quantidades, vimos que ambos, Af e Am, eram competentes quando da realização da prova ECPN. Evidenciamos ainda que Am não demonstrou compreender o significado de termos ligados aos agrupamentos de meses (bimestre, trimestre, semestre).

Os resultados da Prova ECPN (Groupe Cimete, 1995) indicaram que Af e Am eram competentes na contagem termo a termo, cardinalização, comparação de pequenas quantidades, utilização de adições e subtrações simples e identificação de transformação de quantidades. Contudo, demonstraram não ter compreendido, por exemplo, a questão que lhes foi apresentada nos itens 4 e 5 da prova, na qual foram expostos a dois conjuntos $-\mathrm{A}$ e B -, em que A possuía uma quantidade $\mathbf{x}$ e B uma quantidade $\mathbf{x}^{\prime}$. Ao serem solicitados a deixar o conjunto $\mathrm{B}$ com uma quantidade $\mathrm{N}$ a mais que o conjunto $\mathrm{A}$, acrescentaram ao conjunto B a quantidade informada pela pesquisadora, sem considerar o conjunto A. Ou seja, uma dificuldade relacionada ao uso da linguagem (ao significado da expressão "mais que").

Considerando, portanto, os resultados das entrevistas e da prova ECPN, planejamos a segunda fase de coleta de dados desta pesquisa: a intervenção psicopedagógica. Os dados da avaliação psicopedagógica nos ajudaram a concluir que os participantes Af e Am necessitavam de uma intervenção junto à Lógica do Sistema de Numeração Decimal e seus 
algoritmos, além da reelaboração das noções de tempo e da leitura das representações ligadas a essas noções. Sendo assim, propusemos a eles uma intervenção psicopedagógica constituída pelo planejamento da abertura de uma microempresa de docinhos ou salgadinhos de festa - algo que é bastante apreciado por crianças. A nossa intenção era poder abarcar várias situações do dia a dia de uma microempresa: decisão de produtos a comercializar, preço de venda, compras, tempo gasto na produção, entre outros e, assim, relacioná-las a conceitos matemáticos, buscando intervir junto às dificuldades identificadas.

\subsubsection{Segunda fase: as sessões de intervenção psicopedagógica e as entrevistas realizadas após as sessões}

Neste item de nossa dissertação, descrevemos cada uma das 14 sessões de intervenção psicopedagógica que desenvolvemos ao longo da pesquisa. Explicitamos os objetivos de cada uma, o procedimento adotado e a análise dos dados obtidos. Essas sessões envolveram a participação de Af e Am em situação de interação. Como já mencionado no método, as sessões de intervenção se desenvolveram a partir da proposição de situações-problemas baseados no tema que norteou toda a intervenção: o planejamento para a abertura de uma microempresa de doces de festa. Cada sessão seguiu uma rotina geral: no início havia a identificação da data e hora, utilizando como instrumentos o calendário e o relógio analógico, em seguida, realizava-se a retomada da sessão anterior, havia a proposição de uma situação e a resolução de situações-problemas. 


\subsubsection{Primeira sessão de intervenção psicopedagógica}

Data: 29/04/2015 Duração: 32 min e 06 segundos

O objetivo desta primeira sessão foi propor um tema central para o conjunto das sessões de intervenção. Essa situação envolveria o planejamento para a abertura de uma microempresa de docinhos ou salgadinhos de festa.

\subsection{Desenvolvimento, resultados e discussão da primeira sessão}

O foco principal da primeira sessão de intervenção foi a proposição de uma situação-problema central para todas as sessões. A pesquisadora, juntamente como os participantes, definiu que se trabalharia com a situação hipotética do planejamento da abertura de uma microempresa de doces de festa. Foram definidas algumas diretrizes, como, por exemplo: a participação de Af e Am e da pesquisadora de forma interativa, a verificação do horário de início e término e da data de cada uma das sessões.

Logo de início, a pesquisadora questionou Af e Am, a respeito de salgadinhos de festa que mais gostavam. Conversaram sobre as características de alguns deles e a pesquisadora relatou uma história a respeito de uma empresa de salgados de festa que tinha conhecido. Nesse momento, conversaram sobre a criação, o funcionamento e a ampliação desse negócio mencionado pela pesquisadora.

Ao conversarem sobre os salgadinhos, a participante Af demonstrou conhecer o significado da expressão "cento", que geralmente é utilizada para quantificar salgados ou doces, e que designa a quantidade cem. Esse dado foi identificado durante um exemplo dado pela pesquisadora de que a participante Af iria encomendar dois centos de salgados. De imediato, a menina disse que essa quantidade dizia respeito a duzentos salgadinhos. 
Com isso, a pesquisadora apresentou a proposta do tema geral a ser desenvolvido ao longo das sessões de intervenção: o planejamento para a abertura de uma microempresa de salgados ou doces de festa. Essa empresa seria de responsabilidade de Af e Am e eles deveriam optar pela definição do produto a ser produzido (salgados ou doces) e ainda, entre esses, os tipos a serem produzidos e comercializados. Seria necessário, também, organizar as compras de ingredientes, bem como definir os valores de venda.

A pesquisadora convidou os participantes a definirem o produto que eles desejavam para essa empresa. Am foi o único a se posicionar, dizendo que eles poderiam fazer bolos, doces e salgados. A experimentadora solicitou, no entanto, que delimitassem o produto; e a conclusão a que chegaram foi a de que deveriam produzir docinhos. Então, se iniciou uma conversa sobre os doces que cada um conhecia e também apreciava. Os participantes receberam folhas de papel e caneta para registrar os nomes desses doces em uma lista. Dentre os itens relacionados estavam: brigadeiro, bolinho de chuva, beijinho de coco e bolo de churros.

Na sequência, a pesquisadora solicitou a Af e Am que pesquisassem em casa três receitas de doces e as levassem para a próxima sessão. Próximo do final da sessão, os participantes e a pesquisadora conversaram sobre os ingredientes que poderiam fazer parte dessas receitas. Am e Af demonstraram conhecer muitos ingredientes e indicaram também ter noção sobre os procedimentos necessários para o preparo dos doces por eles mencionados.

A participante Af questionou a experimentadora se eles poderiam fazer "de verdade" os doces. A resposta dada a Af foi que, naquele momento, a prioridade era o planejamento da empresa, antes de começar a execução. Além disso, foi dito a eles que no futuro esse planejamento poderia servir para que, de fato, pudessem montar a própria empresa deles: em parceria um com o outro, ou de forma individual. A sessão foi 
encerrada com uma discussão entre os participantes e a experimentadora sobre as especificidades de uma empresa. Sobre o que é ser sócio e as atribuições que cada pessoa tem em uma sociedade empresarial.

Os resultados desta sessão inicial indicaram que Af se mostrou distante das atividades. Ficou parte do tempo com os braços cruzados, sem responder as perguntas que lhe eram dirigidas. Essa atitude demonstrou que, naquele momento, a atividade não estava sendo atrativa para ela. Diferentemente, Am apresentou uma participação ativa. Respondia o que lhe era perguntado e lançava questões. A pesquisadora, por sua vez, demonstrou certa ansiedade durante a intervenção, evidenciada pelos muitos questionamentos feitos aos participantes durante a sessão, principalmente quando propunha uma questão que não era respondida.

\subsubsection{Segunda sessão de intervenção psicopedagógica}

Data: 13/05/2015 Duração: $42 \min$ e 34 s

O objetivo desta sessão foi analisar as receitas de doces, identificar conceitos matemáticos que os participantes dominavam. Na sequência, o objetivo era propor situações-problemas a partir das receitas de doces analisadas.

\subsection{Desenvolvimento, resultados e discussão da $2^{a}$ sessão}

O foco desta sessão foi a investigação dos dados presentes na receita do doce denominado "brigadeiro". Evidenciamos competências relativas à decomposição de números para a realização de cálculos e dificuldades quanto à leitura das horas. Os materiais utilizados para o desenvolvimento da atividade foram: contas quadradas de 
madeira com aproximadamente $3 \mathrm{~cm} \times 3 \mathrm{~cm}$ de comprimento; papel; lápis e receitas de doces de festa.

Nesta sessão, o primeiro procedimento realizado foi o de identificar o horário de início das atividades. A pesquisadora apresentou um relógio analógico, de parede, e perguntou que horas eram. A hora que estava registrada no relógio era $10 \mathrm{~h} 35 \mathrm{~min}$. O participante Am disse que era dez e pouco; e logo em seguida disse que podia ser dez ou onze horas. Perguntado o porquê disso, ele disse não saber. Apontou então para os ponteiros do relógio e afirmou que um deles representava as horas e o outro, os minutos, indicando que existia uma diferença entre eles. A participante Af, que estava em silêncio e um pouco distante da conversa, foi convidada a opinar, mas permaneceu calada.

Considerando que nenhum dos dois informou a hora que estava registrada no relógio, a pesquisadora informou que eram $10 \mathrm{~h} 35 \mathrm{~min}$. Disse, ainda, que as atividades se encerrariam dentro de quarenta minutos e propôs a seguinte situação-problema:

$\mathrm{P}$ - Eu preciso então que vocês digam para mim, qual é a hora que eu preciso marcar aqui, para o relógio despertar, daqui a quarenta minutos. São 10h35min, agora.

Af se pronunciou dizendo que o relógio deveria despertar às $11 \mathrm{~h} 20 \mathrm{~min}$. A pesquisadora questionou como ela havia chegado àquele resultado, e ela disse que tinha contado de cinco em cinco. Foi solicitada, então, que explicasse a Am como chegou àquela conclusão, mas ela não o fez. A pesquisadora, então, realizou, com Am, a contagem de cinco em cinco no relógio e assim descobriram que a hora prevista para o término da sessão seria, na verdade, $11 \mathrm{~h} 15 \mathrm{~min}$. Esses dados sobre a leitura das horas indicaram que os participantes tinham noção da passagem do tempo, sabiam da existência de uma convenção para registrar essa passagem e sabiam que o relógio estava dividido em pequenas partes de cinco minutos. No entanto, não dominavam, ainda, a leitura dessa representação. 
Além da leitura das horas, foi pedido aos participantes que apontassem, no calendário, a data, o dia da semana, o mês e o ano, como descrito no extrato das interlocuções, abaixo:

P - E o dia de hoje? Descobre aí, Af. O dia da semana, o mês e a data.

Am - Eita, Af.

$\mathrm{P}$ - Descobre aí.

Am - Direitinho, Af. \{Am, ficou incitando Af durante a fala da experimentadora. $\}$

Am, percebendo que a colega não estava participando, a incitou a responder as questões. Após essa ação de Am, a participante Af informou todos os dados solicitados, de forma coerente. Esse dado evidenciou a importância das regulações sociais para o desenvolvimento das atividades. Neste extrato, vimos a presença da esfera da interação, relativa às esferas dos atos da fala, o que pode, ser confirmado pelo ato de Am, de desafiar Af.

Na sequência, foi perguntado aos participantes se estavam com as receitas de doces, conforme havia sido combinado na sessão anterior. Af disse que havia pesquisado receita de quibe, mas que não havia trazido. Am disse que não havia pesquisado, pois tinha ido a uma outra atividade que ele fazia depois do horário de aula. A pesquisadora, prevendo que os participantes pudessem ter se esquecido do combinado na semana anterior, levou três receitas de doces sobre as quais haviam conversado (brigadeiro, beijinho de coco e de bolinho de chuva) e as entregou aos participantes, uma cópia de cada.

Iniciaram a leitura da receita do brigadeiro e permaneceram trabalhando com ela até o final da sessão. Primeiramente, Af e Am fizeram a leitura dos ingredientes e do modo de preparo da receita. Em seguida, a pesquisadora questionou-os a respeito do rendimento da receita e sobre o tempo necessário para o preparo dos brigadeiros. Os participantes responderam de forma coerente às questões, pesquisando as respostas no texto da receita. 
O tempo de preparo - 25 minutos - serviu de tema para a proposição de uma situaçãoproblema, que está apresentada a seguir:

P: Nós marcamos aqui, no relógio, quarenta minutos de atividades. Se nós fôssemos começar agora a fazer os brigadeiros, ia faltar ou sobrar tempo? Já que essa receita aqui dura vinte e cinco minutos?

Ambos concordaram que a resposta para a situação era de que sobraria tempo. Am disse que teria mais tempo se fosse hora e não minuto. Af, por sua vez, disse apenas que sobrariam minutos. A pesquisadora perguntou quantos minutos iriam sobrar. Am, tão logo questionado, apresentou duas hipóteses: 10 minutos e 15 minutos. Solicitado, porém, a justificar como chegou ao resultado de 15 minutos, não respondeu, mantendo-se em silêncio. Af, por sua vez, disse acreditar que ele havia contado de cinco e cinco. Mas Am discordou da contribuição da colega. Com isso, descreveu o seu raciocínio expresso no extrato da transcrição, a seguir:

Am - É que eu sei quanto que é vinte mais vinte, é quarenta. Eu vi que tava vinte e cinco, aí eu vi, que era vinte mais vinte que vai ser duas de dez, ai eu pus quinze, que vai dar quarenta.

Am demonstrou, nesse momento, que elaborou uma forma própria de chegar ao resultado. Decompôs o número 40 em duas partes: 20+20. Em seguida, decompôs o número 20 em duas partes: 10+10. Então, deduziu que ao substituir um dos numerais 10 desse último cálculo, por 15 , passaria a ter $10+15=25$. E como $25+15=40$, logo, por meio de um procedimento pessoal, descobriu que 40 minutos menos 25 minutos seriam 15 minutos. Além disso, com relação aos atos da fala, a esfera presente nessa unidade de análise de Am foi a esfera da informação. Isso se deve ao fato de Am descrever o seu modo de raciocínio durante a referida resolução.

Uma nova situação foi proposta para Af e Am utilizando o rendimento da receita. Eles foram levados a pensar sobre uma possível encomenda de um cento de brigadeiros. 
Realizaram alguns cálculos para apontar a quantidade de ingredientes que necessitavam para poder fazer os 100 docinhos. Primeiramente, começaram tentando descobrir quantos doces a mais que 30 , que é o número de rendimento de uma receita, deveriam fazer para chegar ao total de 100. Ambos começaram a sua investigação realizando somas.

Af partiu da soma $30+30$, e obteve como resultado 60 . A esse numeral somou mais 30, obtendo 90 como total. Por fim, somou $90+30$ e atingiu o resultado 120 . Ao chegar a esse último resultado, Af abandonou seu raciocínio, marcando os seus registros com um grande X (a letra xis maiúscula). Provavelmente acreditou que seu procedimento de adições sucessivas, estava errado, pois não encontrou o valor de 100 como resultado dos cálculos que estava propondo. Os valores que encontrou foi de 90 para a soma de três receitas e de 120 para quatro receitas.

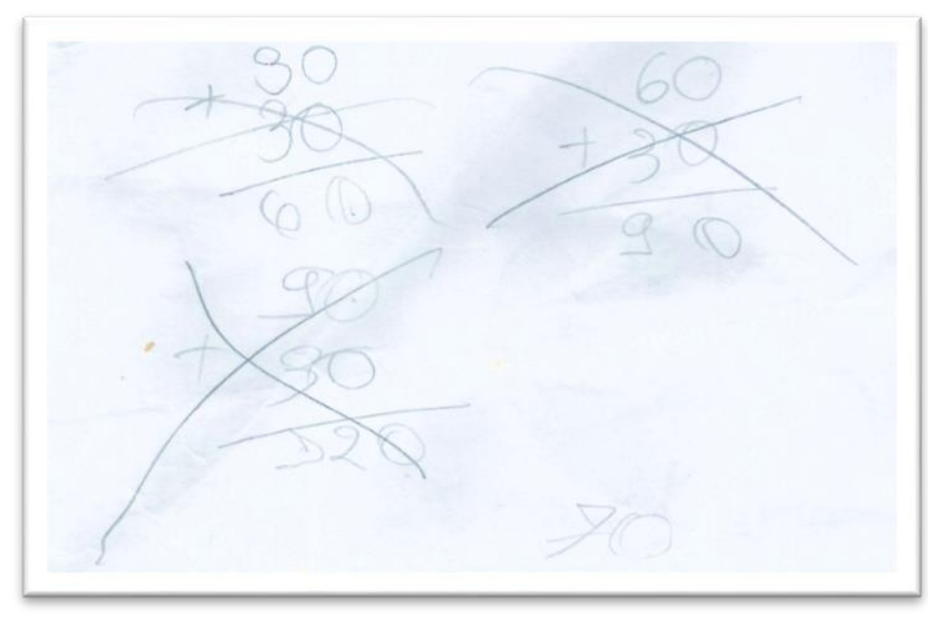

Figura 4. Cálculos de AF para a situação-problema quantas receitas fariam para conseguir produzir 100 docinhos.

Am, por sua vez, realizou três registros para essa questão. No primeiro, fez $30+30+30+30$, mas não indicou nenhum resultado. No segundo, escreveu 30+60 e apresentou como resposta 90. E no terceiro, registrou 70+30, que deu um total de 100 . Provavelmente, no segundo cálculo, ao analisar o resultado de 30+60, Am tenha deduzido que precisava de apenas mais 10 para chegar a 100. Portanto, substituiu o numeral 60 por 
70, no cálculo seguinte. Assim, chegou ao resultado que se deveria produzir mais 70 doces para chegar aos 100 da encomenda. Esse processo mostrou a autorregulação de Am em busca do resultado desejado.

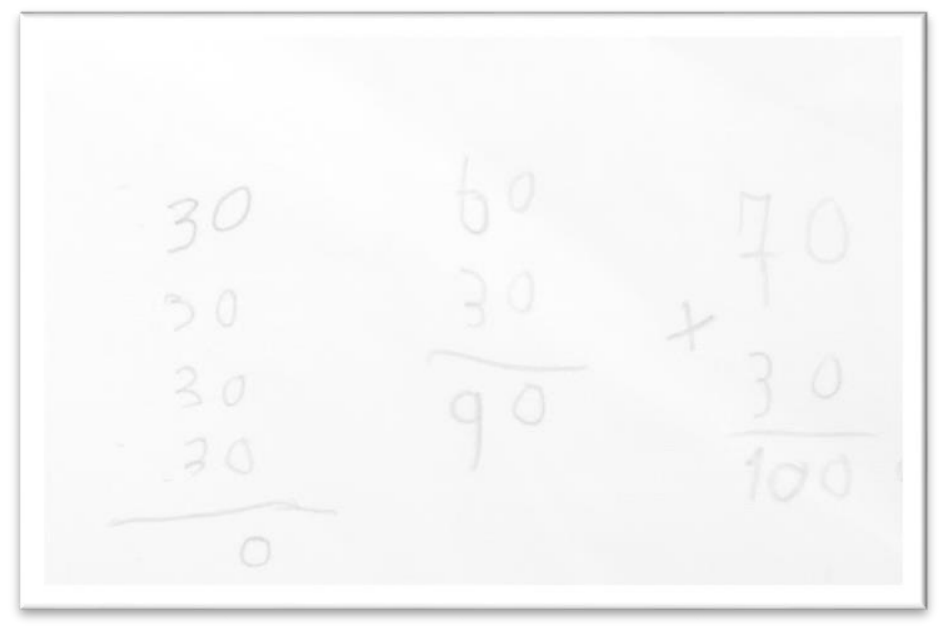

Figura 5. Cálculos de Am para a situação-problema quantas receitas fariam para conseguir produzir 100 docinhos.

Na sequência, a pesquisadora instigou os participantes a identificarem o número de receitas que deveriam fazer para ter um cento de doces. No extrato a seguir, temos a interlocução da pesquisadora com Af e Am.

P - A minha pergunta agora é a seguinte: se a gente fizer três receitas, vai dar noventa. Vocês falaram isso. É suficiente para dar os cem doces?

Af - Hum, hum. Ah, noventa?

$\mathrm{P}-\mathrm{E}$.

Af - Não, não, não é.

$\mathrm{P}-\mathrm{Se}$ eu fizer quatro receitas, eu vou ter cento e vinte. É suficiente para eu ter os cem?

Am: É mais.

Af - Não! Cento e vinte? É.

$\mathrm{P}$ - É, mas só que cento e vinte não é igual a cem? E aí, o que vai acontecer então?

Af - Vai ter mais brigadeiro.

$\mathrm{P}$ - Vai ter mais brigadeiro. Mas e aí? Eu faço três receitas ou quatro receitas?

Af - Três.

Am: Três.

$\mathrm{P}$ - Três vai dar noventa.

Am: NÃO! QUATRO.

$\mathrm{P}$ - Mas aí a gente vai mandar os cento e vinte docinhos para a mulher.

Af - Não. A gente separa. A gente fica com vinte bolinhos e separa. E manda os cem. 
Nesse fragmento transcrito, vemos algumas esferas dos atos da fala se intercalando nessa unidade de análise. Primeiramente, temos as falas da pesquisadora, nas quais predomina a esfera acional, pois, no conjunto das falas, a pesquisadora incita Af e Am a refletirem sobre a questão que ela propõe. Por outro lado, nas falas de Am e Af percebemos um predomínio da esfera da informação, pois passaram boa parte dessa interlocução explicando ou confirmando aquilo que era perguntado por P. Na última fala de Af, no entanto, vemos a presença da esfera acional, quando ela propõe que se envie os 100 docinhos da encomenda e reserve a sobra que correspondia a 20 docinhos.

Nesse extrato, vemos que Af reelaborou o seu entendimento sobre a questão. Isso se confirmou quando ela informou que deveriam fazer quatro receitas, mas que não enviariam os 120 doces do rendimento. Diante disso, vemos que Af tomou consciência de que não havia necessidade de produzir uma receita com o número igual ao da encomenda. Possivelmente, a participante entendeu que não havia cometido um erro quando realizou o cálculo representado na Figura 4.

Após terem chegado ao número de receitas que deveriam preparar para chegar aos 100 brigadeiros, iniciaram uma segunda etapa que foi reorganizar as quantidades de ingredientes na receita. As quantidades que eram iguais a um, como, por exemplo, 1 lata de leite condensado e 1 colher de sopa de margarina, foram de imediato apontadas como 4 na nova receita. Porém, a quantidade que era maior que 1 , como 7 colheres de sopa de achocolatado em pó requisitou dos participantes outros cálculos para chegar à quantidade ideal. Portanto, para descobrir quantas colheres de achocolatado seriam necessárias, ambos os participantes realizaram somas de parcelas iguais $7+7+7+7$.

Af, primeiramente, utilizou a contagem nos dedos. Sua contagem, porém, não apresentou um resultado correto. A experimentadora, então, ofereceu aos participantes algumas peças de madeira para auxiliá-los na resolução. Apenas Af aceitou e Am preferiu 
resolver por meio de algoritmos no papel. Af deu como resposta para essa situação o número 28 e Am, o número 42. A experimentadora questionou quem havia acertado, e Am disse ter sido ele, pois ele havia contado. Af disse a Am que ela também havia contado, pois tinha somado o 7 quatro vezes.

O impasse gerado entre Af e Am, sobre as estratégias utilizadas por cada um, revelou que Am acreditava que ao realizar os procedimentos de cálculo no papel estava mais apto a apresentar uma resposta correta. Talvez Am acreditasse também que por Af ter utilizado o material concreto, soubesse menos Matemática do que ele. Entretanto, a pesquisadora informou que a resposta correta daquele cálculo era 28 , ou seja, mesmo número informado por Af.

A pesquisadora, então, dirigiu-se a Am e perguntou o porquê dele também ter somado o 7 por 4 vezes, assim como o fez Af, e ter obtido resultado diferente dela. Am não soube justificar, indicando que não tinha consciência dos procedimentos de sua ação e que apenas utilizava certas regras ou algoritmos matemáticos, adquiridos na escola.

Nesse momento da sessão, surgiu entre os participantes uma rivalidade. Ambos desejavam estar certos e refizeram seus cálculos. Af não mudou sua estratégia, apenas recontou as peças de madeira. Am, no entanto, abandonou a soma de parcelas iguais e registrou marcas no papel. Desse modo, os dois chegam ao resultado 28. 


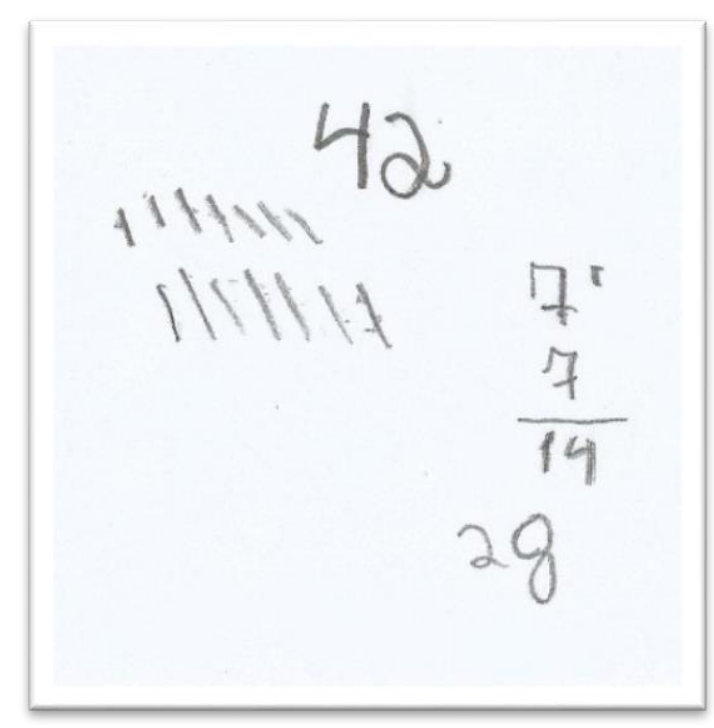

Figura 6. Estratégia utilizada por Am para o cálculo de 7+7+7+ 7

A receita em questão apresentou a opção de se utilizar dois tipos de achocolatado em pó, de marcas diferentes. O achocolatado da primeira marca necessitava de 7 colheres e o achocolatado da segunda marca necessitava de 4 colheres. Como os participantes já haviam descoberto o total para as 4 receitas referentes à primeira marca, havia ainda, a necessidade de descobrirem quantas colheres no total seriam necessárias para a segunda marca. De imediato, Af disse que faria $4+4+4+4$, utilizando as peças de madeira, porque, segundo ela, era mais fácil. Am, no entanto, não quis participar. A pesquisadora encorajou Am a verificar se Af estava certa. Com isso, ele decidiu resolver a questão. Utilizando o papel, registrou quatro fileiras, com quatro marcas cada, e as contou uma a uma, chegando ao mesmo resultado de Af, 16. Naquele momento foi possível verificar que Am começou a perceber que existiam outras formas de realizar os cálculos, que não fossem apenas o algoritmo.

A pesquisadora apresentou, ainda, uma última questão aos participantes. Questionou se fariam todas as receitas ao mesmo tempo ou se cada uma delas separadamente. Am e Af decidiram que fariam uma de cada vez e lhes foi proposta, então, 
outra situação. Deveriam descobrir quanto tempo, no total, iriam gastar para produzir os 120 brigadeiros das quatro receitas. A decisão da pesquisadora em lançar essa questão desconsiderou toda a construção que foi feita anteriormente, quanto à descoberta dos ingredientes necessários para o preparo das quatro receitas. Isso porque, se já haviam descoberto quantos ingredientes eram necessários para quatro receitas, não haveria sentido preparar uma receita de cada vez. No entanto, Af e Am se mostraram disponíveis e resolveram a proposição que lhes foi feita.

Af disse que deveria fazer 25 quatro vezes e deu como resposta 47. Para os cálculos, utilizou as peças de madeira como das outras vezes. Am, por sua vez, calculou $25+25+25+25$ no papel. Ele primeiramente respondeu que dava 90 . Ao ser solicitado a rever seus cálculos, descobriu que, na verdade, a resposta correta era 100. E comemorou ao saber que a sua resposta estava correta e a de Af não. Os dois participantes utilizaram a mesma estratégia que haviam empregado anteriormente; no entanto, o êxito foi inverso. Ou seja, Af errou a resposta utilizando o material concreto e Am acertou utilizando algoritmos no papel. Observa-se que quando os cálculos envolveram números de extensão pequena, como 4 e 7, o uso de material concreto se mostrou uma ferramenta de grande utilidade. Porém, quando o número apresentou uma extensão maior, como foi o caso do numeral 25, o êxito se deu por meio do cálculo no papel.

Am explicou que utilizar o papel favoreceu o acerto, pois no papel se fazem cálculos. Af, porém, não concordou com a opinião dele, e disse que não tinha "nada a ver". A pesquisadora interviu dizendo que Af havia feito cálculos, sim, apesar de não ter utilizado o papel. Isso gerou um incômodo em Am, que disse que não sabia fazer nada certo. Surgiu, então, uma questão que poderia ser analisada em outras sessões: "por que a utilização de material concreto levou ao acerto em um dado momento e em outro não?" E 
da mesma forma: "por que os cálculos no papel levaram ao erro em um dado momento e ao êxito em outro?"

Os resultados desta sessão revelaram dois importantes dados. O primeiro deles diz respeito à crença cultivada por Am de que somente por algoritmos escritos no papel podese obter a resposta correta em Matemática. O segundo resultado refere-se à incompreensão de Am e Af de que uma soma de parcelas iguais, de fato, pode ser transformada em uma multiplicação.

\subsubsection{Terceira sessão de intervenção psicopedagógica}

Data: 20/05/2015 Duração: 43min30s

O objetivo desta sessão foi reconhecer a operação de multiplicação em situações de adição de parcelas iguais. Era intenção, também, refletir sobre esses registros e, assim, elaborar novos procedimentos de resolução dos cálculos.

\subsection{Desenvolvimento, resultados e discussão da terceira sessão}

O foco da terceira sessão foi a transformação de adições de parcelas iguais em multiplicações. Utilizamos palitos de picolé como instrumentos de apoio à contagem, papel e lápis para registro.

A sessão foi iniciada com a verificação da data no calendário de mesa, e o horário de início e de término da sessão no relógio analógico. Am e Af informaram que a hora inicial era 9h10min e, assim, foram convidados a prever quando a sessão deveria se encerrar, considerando que trabalhariam por 40 minutos. Af disse que terminaria às 9h39min. A pesquisadora, relembrando a estratégia utilizada pelos participantes na sessão 
anterior, ou seja, a contagem dos minutos de cinco em cinco, no relógio, sugeriu então que utilizassem essa mesma contagem para conferir a resposta apresentada.

Realizaram o mesmo procedimento, portanto, e Am apontou que no numeral 10 teríamos os 40 minutos, afirmando também que aquela posição dos ponteiros corresponderia a 10 horas. A pesquisadora solicitou que conferissem a hora quando chegasse ao numeral 10, utilizando novamente a contagem de cinco em cinco no relógio. Af e Am repetiram, então, a contagem e identificaram a hora correta, que seria $9 \mathrm{~h} 50 \mathrm{~min}$. Af apresentou, ainda, outra forma de nomear esse horário: "10 para às 10". Isso significou que Af compreendia a possibilidade de os números assumirem valores diferentes, de acordo com a posição ou contexto em que estavam. Podemos inferir, também, que esta era uma das formas utilizadas para a leitura das horas, por Af, em seu dia a dia.

Na sequência, a pesquisadora incitou uma conversa a respeito do que havia sido feito na sessão anterior. Apresentou os cálculos produzidos na referida sessão $(30+30+30+30=120)$ e perguntou se não haveria uma forma diferente de registrá-los. Af prontamente respondeu que "sim" e apresentou o seguinte procedimento: $50+50=100$ e $100+20=120$. Essa ação de Af indicou que ela sabia utilizar diferentes modos para chegar a um mesmo resultado. Em outras palavras, ela tinha desenvolvido a capacidade de compor e decompor números, assim como proposto por Yang et al. (2008).

Apesar do procedimento proposto por Af, a pesquisadora não deu sequência à proposta e insistiu na mesma questão: "haveria outra forma de representar $30+30+30+30=120$ ?". Af apresentou oralmente, mais um procedimento baseado ainda na decomposição dos valores e na adição: $6+6=12$ e $12+12=120$. Ao ser solicitada pela pesquisadora a registrar esses cálculos no papel, Af registrou o cálculo " $12+12$ " e 24 como resultado. Percebendo que sua proposta não atenderia às necessidades impostas pela situação, Af abandonou o procedimento que estava realizando e iniciou um novo: 
$" 30+40=70,70+30=100,100+10=110,110+10=120 "$. Ao lhe ser solicitado que explicasse sua escolha de procedimento, Af justificou que decidiu fazer desta maneira por saber que as somas daqueles números dariam as respostas que ela queria (Ver figura 8).
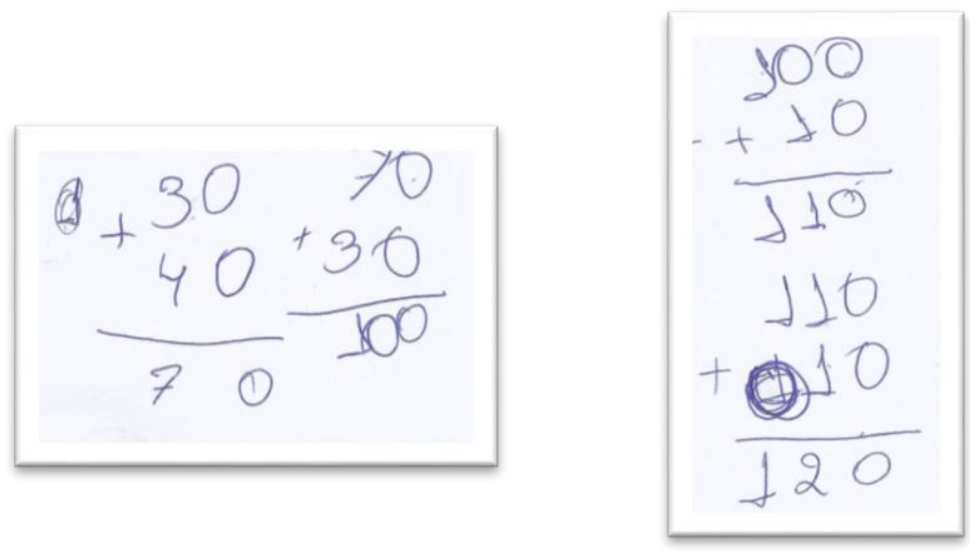

Figura 7. Registros dos procedimentos de Af.

A pesquisadora, novamente, não deu sequência à proposta de Af e insistiu na busca de outra forma de representar " $30+30+30+30$ ", sugerindo que utilizassem os palitos nessa demonstração. A intenção da pesquisadora era que os participantes pudessem visualizar, nos palitos, os quatro grupos de 30. Ela supunha que, dessa forma, eles relacionariam a adição " $30+30+30+30$ ", representada nos palitos sobre a mesa, com a multiplicação " 4 x 30". Sendo assim, ela retomou com Af e Am o registro de " $30+30+30+30$ ” e questionou-os sobre a quantidade de vezes que aparecia o numeral 30 naquela adição de parcelas iguais. E obteve como resposta: "quatro vezes". Diante disso, deu prosseguimento à atividade com os palitos. Sugeriu aos participantes que cada um, inclusive ela, ficassem responsáveis por contar 30 palitos. Formaram, assim, 3 grupos de 30 palitos, e o quarto grupo foi formado por Af com o auxílio de Am e da pesquisadora.

Com os 4 grupos de 30 palitos sobre a mesa, a pesquisadora insistiu em perguntar se existiria uma outra forma de representar " $30+30+30+30$ " que fosse semelhante a algo aprendido por eles na escola. Contudo, não obteve nenhuma resposta. Sua intenção, nesse 
momento, era conduzir Af e Am ao registro formal da multiplicação. Vale ressaltar a dificuldade da pesquisadora em não desenvolver as propostas de Af. Assim, a pesquisadora abandonou a sequência que vinha sendo realizada e propôs um novo cálculo: $12+12$. A intenção era que, a partir da visualização de uma adição com menos parcelas, ficasse mais claro para Af e Am a relação entre a adição de parcelas iguais e a multiplicação.

Ela propôs o cálculo $12+12$ e perguntou se existiria uma forma de representar que não fosse a soma, Af apresentou a sua sugestão de procedimento. Primeiro disse que o resultado de $12+12$ era 24 e que poderia fazer uma subtração. No entanto, a pesquisadora lhe disse que esperava que ela fizesse outra operação. Nesse momento, Af disse que poderia ser feita uma multiplicação, ou seja, 2 x $12=24$. Nesse momento, a pesquisadora incitou uma conversa sobre o significado da palavra "vezes" tendo como base o cálculo 2x12. Af disse que a palavra "vezes" indicava a quantidade de vezes que um número se repetia em uma conta de multiplicação. Com isso, a pesquisadora retomou a operação $30+30+30+30$, e solicitou aos participantes que a transformassem em uma multiplicação, considerando a explicação de Af e o que fizeram no cálculo $12+12$.

Os participantes, porém, não executaram a ação solicitada pela pesquisadora; então, ela sugeriu que poderiam registrar aquela operação da seguinte forma: " $4 \times 30$ ". E perguntou aos participantes o que ela havia feito ao escrever 4x30. Am e Af não responderam a pergunta, mas, sim, foram em busca de um resultado para o algoritmo apresentado (“4x30"). Essa atitude significou que os participantes atuaram da mesma maneira como se estivessem no contexto de sala de aula, no qual a professora geralmente demandava dos alunos o alcance das respostas corretas para as questões propostas e não a reflexão e a discussão conceitual.

A pesquisadora insistiu em conversar sobre os conceitos e significados subjacentes àquele algoritmo. Af explicou que substituir a adição de repetidas parcelas $(30+30+30+30)$ 
pela multiplicação (4x30) é uma forma mais fácil de resolver a adição. Em seguida, iniciou a resolução do algoritmo. A pesquisadora, porém, lhe disse que não era necessário resolver o algoritmo, mas apenas explicar o que ele significava. Em outras palavras, ela estava instigando os participantes a pensarem conceitualmente a multiplicação.

Com base nessas informações, podemos dizer que quanto ao desempenho dos participantes Af e Am, identificamos dois resultados. O primeiro deles é o que Am ainda não havia compreendido que um mesmo símbolo matemático podia ser utilizado em diferentes situações e com diferentes significados, isso ficou evidente na leitura das horas. O segundo resultado explicitou que Af e Am não estavam habituados a refletir sobre suas produções matemáticas e nem mesmo sobre conceitos. Tal problema nos apontou a necessidade de propor mais situações com uma finalidade específica de levar os participantes a ultrapassarem suas conclusões elementares a respeito dos cálculos matemáticos, em direção a pensamentos mais complexos. Essa necessidade se deu principalmente no que se refere à formação dos conceitos matemáticos, em especial aqueles relacionados à multiplicação. Esta sessão evidenciou, também, que a natureza da mediação desenvolvida pela pesquisadora deveria ser alterada no sentido de superar o tipo de questões escolares que busca uma única resposta.

\subsubsection{Quarta sessão de intervenção}

Data: 27/05/2015 Duração: 45min

O objetivo desta sessão foi elab11'orar e resolver situações-problemas de multiplicação com uso de material concreto. Perceber como se formava uma operação de multiplicação a partir da adição. 


\subsection{Desenvolvimento, resultados e discussão da quarta sessão.}

A quarta sessão se desenvolveu em torno da resolução de uma situação-problema envolvendo a encomenda de brigadeiros para uma festa de aniversário. Nesta sessão, tivemos um problema com o equipamento de gravação de áudio, por esse motivo os minutos iniciais, referentes à pesquisa da hora e data da sessão, foram perdidos. Como material de contagem, foram empregados palitos de picolé e forminhas de papel utilizadas para acondicionar brigadeiros. Foram usadas, ainda, folhas de papel A4, nas quais se registraram os cálculos ao longo da sessão.

Inicialmente, a pesquisadora mostrou forminhas de brigadeiro a Af e Am e iniciou uma conversa em torno das características do material. Abriram os pacotes de forminhas e, então, fizeram um desenho representando-as ainda no pacote, antes de abri-lo e depois separadas umas das outras, fora do pacote. Os participantes identificaram que cada pacote continha 10 pequenos grupos de forminhas com 10 unidades em cada uma.

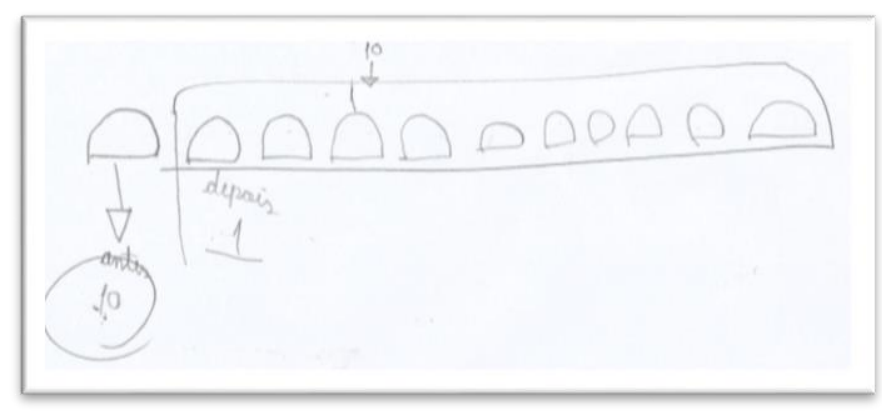

Figura 8. Representação de Am para as forminhas de brigadeiro, antes e depois de abertas.

Foram propostas oralmente, pela pesquisadora, algumas questões utilizando as forminhas. Entre elas, destacamos: "Quantas forminhas temos em 4 grupinhos de 10 forminhas? Um pacote, fechado, de forminhas de brigadeiro, possui quantas forminhas no total? Quantos grupos de 10 temos em um pacote de forminhas? Dois pacotes de 
forminhas, fechados, possuem quantas forminhas no total?" Todas as questões foram respondidas por Af e Am oralmente e de forma coerente. Nessas questões formuladas pela pesquisadora, percebemos nitidamente a esfera da interação, pois ela visava desafiar os participantes a observar e investigar, junto ao material concreto, as questões por ela propostas.

Na sequência, a pesquisadora propôs a situação-problema que perpassou toda a sessão, que consistia na encomenda de brigadeiros, por parte de uma avó, para o aniversário da neta. Primeiramente, a pesquisadora e os participantes, Af e Am, conversaram a respeito das possíveis perguntas que se poderia fazer, a essa senhora, antes de anotar o seu pedido. Entre as tais perguntas, destacamos: "Quantos serão os seus convidados?”, “Quantos brigadeiros cada pessoa poderá comer na festa?”. A pesquisadora enfatizou a Af e Am que antes de decidir o número de doces a se produzir para essa festa, seria necessário pensar no número de convidados e de brigadeiros que cada pessoa poderia comer, por isso a importância de se pensar nas perguntas a se fazer à avó.

Assim, a pesquisadora pediu que Af e Am definissem um número de convidados que imaginavam que pudessem estar presentes na festa da referida avó. O número, por eles escolhido, foi 99. Além disso, definiram, também, que cada convidado poderia comer cerca de seis brigadeiros.

Essas questões engendraram a seguinte situação-problema: Quantos brigadeiros deveriam ser produzidos pela fábrica de doces, de Am e Af, considerando que na festa dessa avó haveria 99 convidados e cada um poderia comer seis brigadeiros? A pesquisadora solicitou a eles que resolvessem a situação. Assim, Af respondeu, de imediato, que teriam de fazer 200 brigadeiros. Esboçou uma explicação utilizando palitos, mas que resultou em informações muito confusas e então a pesquisadora lhe pediu que esclarecesse melhor a situação. Contudo, a única resposta dada foi que havia aprendido 
aquilo com sua professora. $\mathrm{O}$ que sugere pensar que Af estivesse tentando apresentar alguma regra que havia aprendido na escola, mas que não estava conseguindo verbalizá-la de forma inteligível.

Na sequência, a pesquisadora dispôs 11 palitos sobre a mesa representando os convidados da festa. Embora o número 99 tenha sido definido, anteriormente, como o número de convidados, nesta situação esse valor foi desconsiderado pela pesquisadora. $\mathrm{O}$ número de brigadeiros destinado a cada um dos convidados, que era de seis brigadeiros, foi mantido, mas ela preferiu que manipulassem um número menor em relação ao total de convidados. Sua atitude não invalidou a intervenção, mas reduziu as possibilidades dos indivíduos em propor estratégias diferentes para transpor desafios relativos às situaçõesproblemas.

Na sequência, foram dispostas sobre a mesa, ao lado de cada palito, seis forminhas de brigadeiro. Para descobrir o número de brigadeiros que os onze convidados comeriam no total, e que estavam representados sobre a mesa, os participantes desenvolveram dois procedimentos diferentes. No primeiro, realizaram contagem termo a termo; e apresentaram, como total, o número 52. A pesquisadora, no entanto, colocou em dúvida a resposta deles e, por isso, realizaram o segundo procedimento. Sem que fossem solicitados, fizeram registros de cálculos no papel para descobrir quanto daria 11 vezes o número seis. 


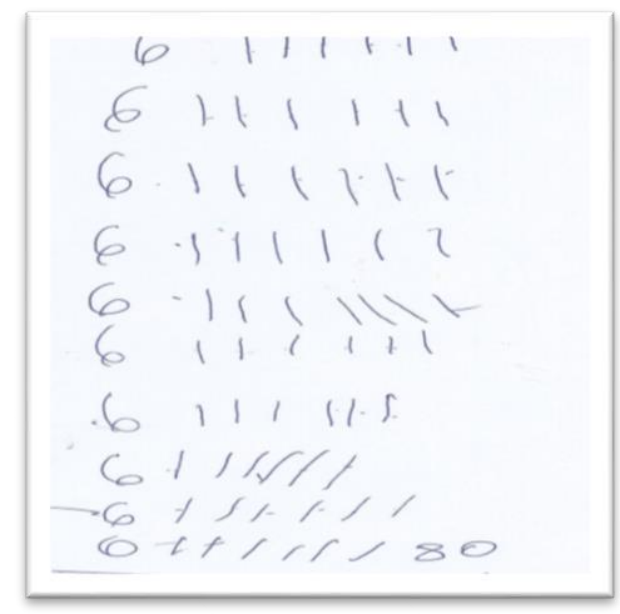

Figura 9. Registro de Af

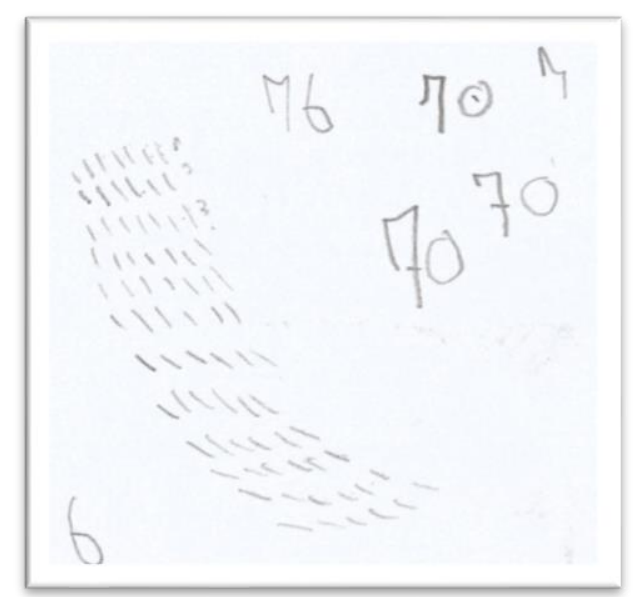

Figura 10. Registro de Am

Nesses registros, Af e Am apresentaram respostas diferentes para a situação. Af apresentou como resposta 80 e Am 76. A pesquisadora perguntou o porquê de os dois estarem trabalhando com os mesmos números e terem obtido diferentes resultados. Mas sua pergunta não foi respondida, pois Af apareceu com uma estratégia nova para a situação. 
Af dispôs sobre a mesa apenas seis palitos de picolé, e disse que iria contá-los 11 vezes. A pesquisadora sugeriu que registrassem no papel uma marca para cada vez que ela finalizasse uma contagem. Af aderiu à sua sugestão e Am ficou responsável por fazer as tais marcas no papel. Antes, porém, que iniciassem esse procedimento proposto por Af, o participante Am recontou todas as forminhas e informou que havia um total de 66 forminhas sobre a mesa. Em seguida, realizaram a estratégia sugerida por Af; e também encontraram como resultado o numeral 66. Essa atitude de Af revelou o quanto ela estava se desenvolvendo no que se refere ao pensamento lógico-matemático. A seguir temos o extrato dessa interlocução:

$\mathrm{P}-\mathrm{O}$ que você está tentando fazer Af?

Af - Eu vou tentar pegar 6 palitos e vou tentar fazer de 6 em 6 em cada coisinha.\{Pela primeira vez, com o material concreto, Af percebe que pode usar uma única base de 6 palitos, sem precisar recorrer a vários grupos e 6, pra chegar ao resultado que deseja\}

P - Legal! Gostei dessa sua ideia. Faz para todo mundo, que a gente te ajuda. Tá?

Am - Faz assim: Peraí Af, deixa eu ver se eu entendi o que você vai fazer. Você vai contar só nesses 6 palitos aí?

Af - Hum hum!

$\mathrm{P}$ - Aí você quer que a gente vá marcando no papelzinho o número de vezes que você contou 6 ?

Af - Ahã! \{Am começou a contar um a uma das fominhas de brigadeiro sem que fosse solicitado para fazer isso.

Ao analisar esse trecho, podemos ver que Af se engajou em um procedimento proposto a partir de suas autorregulações. Esse ato de engajar e também propor revela que a esfera dos atos da fala presente nesse trecho, em relação à participante Af, diz respeito à esfera acional. Enquanto isso, a esfera presente nas falas da pesquisadora diz respeito à esfera da interação, tendo como principais atos o de complementar e o de reconhecer.

Nesta sessão, pudemos ver que cada um dos participantes, inclusive a pesquisadora, demonstraram mudanças em seu desempenho. Af mostrou estar bastante envolvida nas situações propostas, revelando capacidade de resolução de problemas a partir de suas próprias estratégias. Am, por sua vez, mostrou-se mais favorável à utilização de material 
concreto para auxiliá-lo na elaboração de estratégias de resolução dos problemas. Conseguiu entender que um determinado número pode ser formado por pequenos grupos da mesma quantidade. Percebeu, que o número 200 é formado a partir de 10 grupos de 20 unidades. Concluímos que esse foi um importante passo para Am compreender a multiplicação como o resultado de adições de parcelas iguais.

Quanto à pesquisadora, ficou evidente que ainda necessitava de mudanças quanto à natureza de sua mediação. Era necessário que ela se distanciasse da reprodução do modelo de mediação escolar, calcada na explicação de conteúdos. Vale ressaltar que nesse modelo permite-se pouco espaço para os participantes construírem suas próprias estratégias para a resolução da situações-problemas.

\subsubsection{Quinta sessão de intervenção}

Data: 03/06/2015 Duração: 49 min e 46 s

O objetivo desta sessão foi elaborar e resolver situações-problemas de multiplicação com material concreto, utilizando grandes quantidades. Propor procedimentos pessoais para a resolução dos cálculos.

\subsection{Desenvolvimento, resultados e discussão da quinta sessão}

A sessão iniciou-se como as anteriores, com a leitura das horas e identificação da data. No entanto, nesse dia, quem tomou a frente dos trabalhos foram os participantes Af e Am. Am entrou no Laboratório de Aprendizagem e, de imediato, segurou o calendário dizendo a data da sessão e as das próximas. Ele informou a hora, 9h05min, no que foi 
corrigido por sua colega Af, que disse ainda não ser 9h05min, mas sim 9h04min. Esses primeiros dados da quinta sessão revelaram que a nossa insistência em utilizar o relógio em todas as sessões já começava a apresentar resultados, pois na primeira sessão os participantes não conseguiam sequer dizer a hora corretamente. Nesse momento da intervenção, porém, já estavam se corrigindo devido à diferença de um minuto entre a contagem real expressa no relógio e a resposta dada por Am.

Em seguida, a pesquisadora convidou os participantes a relembrarem a sessão anterior. Referiram-se às forminhas de brigadeiros e às suas quantidades. Quando ela estava para propor uma situação a eles, Am começou a falar dos pastéis feitos por seu avô, e isso serviu de tema para a primeira situação-problema da sessão. Am contou que havia três pessoas em sua casa: sua avó, seu avô e ele, e que seu avô havia feito sete pastéis para cada uma delas.

Com base nessa situação, semelhante ao que foi feito na sessão anterior, dispusemos sobre a mesa três palitos de picolé para representar cada uma das pessoas do problema. Em seguida, distribuímos sete palitos, que representavam os pastéis, para cada pessoa. Logo após, conversamos sobre a quantidade que cada um iria comer e quantos haveriam de sobrar, considerando que a avó de Am comeria 2 pastéis, enquanto Am e seu avô comeriam 3. E investigamos quantos pastéis seriam feitos no total. Para encontrar essa resposta, Am e Af disseram que seria necessário fazer 7+7+7 e utilizaram os dedos para contagem. Am disse a Af que começasse a contar do 15 pois já sabiam que $7+7$ era igual 14 e não seria necessário contar novamente. Af aceitou a sugestão do colega e concluíram que haviam sido feitos 21 pastéis.

A próxima situação-problema foi proposta pela pesquisadora e envolveu a avó de Af. Ela havia feito 120 brigadeiros para 100 pessoas. A questão inicial que deveria ser resolvida era calcular quantos brigadeiros cada pessoa poderia comer. Af supôs que cada 
uma delas poderia comer 10 brigadeiros do total de 120 feitos por sua avó. Espalhamos sobre a mesa 100 palitos de picolé, representando as pessoas. Começamos a separar as forminhas dos pacotes para, em seguida, distribuí-las. Am percebeu que já havia muitas forminhas sobre a mesa e então sugeriu que Af e a pesquisadora conferissem se de fato teriam 120 forminhas entre elas. Disse também que uma forma de facilitar a contagem seria contar as forminhas de $10 \mathrm{em} \mathrm{10.} \mathrm{E} \mathrm{assim} \mathrm{foi} \mathrm{feito.}$

Após conferir que tínhamos 120 forminhas, começamos a distribuí-las entre as 100 pessoas. A nossa primeira distribuição somente atendeu a 12 pessoas. A pesquisadora questionou o que deveriam fazer para resolver o problema das outras pessoas que não receberam brigadeiros. A solução sugerida por Af foi diminuir o número de brigadeiros que cada pessoa receberia. Decidiram então que cada pessoa receberia cinco brigadeiros. Contudo, ao final dessa nova distribuição, ainda ficaram pessoas sem receber os doces.

Propuseram, assim, diminuir, mais uma vez, o número de brigadeiros por pessoa. Assim, começaram a distribuir quatro brigadeiros para cada uma. Vendo que, mesmo assim, não atenderiam a todas as pessoas, os participantes decidiram aumentar o número de brigadeiros produzidos. Com isso, o número de brigadeiros deixou de ser 120 e passou a ser 200. E começaram a distribuir novamente quatro doces para cada pessoa. Em uma mesa foram distribuídas as 120 forminhas de brigadeiros para 30 pessoas. Como a mesa tinha sido toda ocupada pelas forminhas e palitos que representavam as pessoas, passamos para outra mesa onde haveríamos de distribuir 80 brigadeiros para o restante das pessoas, que ainda não haviam recebido nenhum brigadeiro. Assim, continuamos distribuindo quatro brigadeiros para cada pessoa.

Esta sessão foi encerrada com uma última indagação da pesquisadora a Af e Am. Ela queria ter certeza da quantidade de fominhas representando brigadeiros na outra mesa. E perguntou como poderiam chegar a essa resposta. Af foi categórica em dizer que seria 
muito simples. Eles contariam quantos grupinhos de quatro havia sobre a mesa. Para facilitar mais ainda a contagem, Af sugeriu que dividissem os grupinhos de quatro em três outros grandes grupos. Cada grupo seria de responsabilidade de um dos participantes da sessão. Assim, ao final da distribuição, a pesquisadora e Am ficaram com cinco grupinhos de quatro cada um e Af ficou com 10 grupinhos de quatro. Finalizamos a sessão combinando que, na próxima, descobriríamos o total de forminhas que os três, Af, Am e pesquisadora, teriam juntos.

Nesta sessão, observamos que a pesquisadora mediou as situações sem se pautar pelo modelo escolar, apresentando um modelo, cada vez mais, de intervenção. Deixou de lado uma postura de transmissão do conhecimento, de detentora do saber, passando para uma postura de interlocutora da situação de aprendizagem. Nesta sessão, portanto, ela passou a dar voz e credibilidade às situações trazidas por Af e Am. Quanto aos participantes, pudemos percebemos que estavam, cada vez mais, à vontade durante o encontro. Enquanto na primeira sessão quase não falavam, nesta podemos ver que a maior parte do tempo foram os dois, Am e Af, os interlocutores mais ativos da sessão.

A quinta sessão pode ser considerada como um divisor de águas da pesquisa. Em primeiro lugar, destacamos a mudança de postura da pesquisadora. Ela deixou de lado a mediação baseada no modelo escolar e passou a dar voz aos participantes da pesquisa, principalmente no que diz respeito às proposições e sugestões ao longo da sessão. Em segundo lugar, os participantes, Af e Am, mostraram-se muito mais engajados nas atividades propostas. Podemos observar ainda, que os participantes se engajaram na investigação de meios diversos para chegar a solução das situações-problemas. 


\subsubsection{Sexta sessão de intervenção}

Data: 10/06/2015 Duração: 40 min

Esta sessão teve dois objetivos. O primeiro deles foi trabalhar o conceito de multiplicação, utilizando as situações de formação de grupos de quantidades iguais. O segundo objetivo foi registrar, no papel, as situações-problemas, resolvidas com o uso do material concreto.

\subsection{Desenvolvimento, resultados e discussão da sexta sessão}

Esta sessão teve como foco a finalização da situação-problema, que fora proposta na quinta sessão, que envolvia os 120 convidados e os 200 brigadeiros.

A sessão se iniciou com, Af, Am e a pesquisadora conversando sobre o feriado que havia ocorrido na semana anterior. Entre os relatos, destacou-se o fato de que a avó de Af que tinha feito pães de queijo. A menina explicou que sua avó havia feito sete bandejas, com 20 pães de queijo cada uma. Com isso, a pesquisadora utilizou a experiência de Af para propor uma situação-problema. Ela perguntou "quantos pães de queijo foram feitos no total". Para responder à questão, Af, sem hesitar, solicitou à pesquisadora que apresentasse 7 dedos. Ela pediu que a pesquisadora fosse "tirando" os dedos conforme ela fosse contando. Dessa forma, a cada número falado por Af, a pesquisadora deveria baixar um dedo. Af iniciou a contagem pelo número 20 e continuou contando de 10 em 10. Am percebeu o equívoco da colega, em contar de 10 em 10 e não de 20 em 20, e a corrigiu. Com isso, Af reiniciou a contagem, desta vez de 20 em 20, e obteve como total 140, o que correspondia aos pães de queijo das sete bandejas. Esse dado evidenciou que Af sabia 
realizar a contagem pela repetição de agrupamentos, tanto de 10, como de 20. Evidenciou também que Am estava atento ao procedimento da colega, o que resultou em regulação sociocognitiva que influenciou a mudança de procedimento de Af.

A pesquisadora perguntou a Af se ela teria contado uma por uma das bandejas de pão de queijo. Af explicou que não havia sido necessário, já que havia contado a quantidade de uma delas. Logo, se soubesse a quantidade de uma bandeja, era fácil saber quantos haveria nas sete bandejas. Ou seja, Af percebeu que poderia utilizar, em sua vida pessoal, um procedimento desenvolvido nas sessões de intervenção.

Os pães de queijo serviram, ainda, de tema para outra situação-problema. Af explicou que comeu 10 pães de queijo em um dia, 10 no outro dia e levou três para a escola. A pesquisadora perguntou quantos pães de queijo ela havia comido no total. Am disse que a colega comera 13 pães de queijo. E Af o corrigiu dizendo que o total era, na verdade, de 23 pães de queijo. E justificou sua resposta dizendo que 10+10+3 era igual a 23. A pesquisadora aproveitou a resposta de Am para propor uma nova situação. Caso Af tivesse comido apenas 13 pães de queijo, como poderia distribuí-los, de tal modo que fossem comidos ao longo dos mesmos três dias mencionados. E Af informou, então, que poderia comer cinco em um dia, cinco em outro e três na escola. Essa resposta de Am mostra que já estava fazendo, informalmente, uso dos princípios da operação da divisão.

Naquele momento, retomaram a situação que ficou pendente na sessão anterior. Relembraram todas as distribuições que fizeram dos 100 brigadeiros para as 120 pessoas. Depois, retomaram a distribuição das 80 forminhas para as pessoas que ainda não haviam recebido brigadeiros. Essa distribuição foi feita ao final da sessão anterior e tinha a seguinte configuração: cinco grupos de quatro forminhas + cinco grupos de quatro forminhas +36 forminhas separadas 
Af, Am e a pesquisadora dispuseram sobre a mesa essa configuração de forminhas. Então, a pesquisadora disse que teriam de contar todas as forminhas para ver se tinha as 80 que eles queriam. Antes, porém, que pudessem contar e chegar ao resultado, ela lançou uma pergunta, que está reproduzida na fala a seguir, juntamente com a resposta dada por Af.

P - Ah, está legal! (...) por que é mais fácil contar quando está em grupinhos? Hein, gente?

Af - Não sei.

$\mathrm{P}$ - Por que será?

Af - Porque em grupinho dá para pensar como é que é.

$\mathrm{P}$ - Hã? Pensar, como assim?

Af - Pensar assim: 10, 20, 30. Entendeu?

Neste trecho, temos presente a esfera da interação nas falas da pesquisadora e a esfera da informação nas falas de Af. Vemos a pesquisadora desafiando Af para justificar a sua ideia, e Af, sem hesitar, informou o que estava querendo dizer. Esta resposta de Af é muito importante para os resultados desta sessão, pois, provavelmente a menina estivesse querendo dizer que dividir em grupinhos facilita a compreensão dos conceitos subjacentes àquela representação. Na sequência desse trecho, Af disse que para encontrar o total de forminhas, era necessário somar as quantidades dela às quantidades de Am e a da pesquisadora. Dessa forma, somaram 36 com 20, com mais 20.

Af registrou no papel a soma de $20+20$ (total de Am e da pesquisadora) e apresentou como resultado 40. Depois somou este resultado a 36, que era o seu total de forminhas. Obteve, então, o número 76. Af, porém, se equivocou e somou o número 40 ao 76 encontrado. E justificou que estava somando o resultado dela ao de Am e ao da pesquisadora. Com isso, disse que esse total era de 116. Resultou um número de forminhas superior ao que realmente estava sobre a mesa. Am mostrou-se duvidoso do procedimento apresentado por Af, mas não soube justificar o que estava achando diferente. Essa atitude 
de dúvida de Am indica que ele estava elaborando raciocínio mais complexo, o que o impedia de aceitar qualquer resposta como a possível para aquela situação.

Sendo assim, a pesquisadora solicitou que recontassem as forminhas sobre a mesa para verificar se realmente haveria as 116 forminhas do resultado apresentado por Af. Contaram, então, as forminhas sobre a mesa, e descobriram que só havia 76 forminhas e não 116. Nesse momento, a mediação da pesquisadora se direcionou no sentido de levar Af a perceber o que havia feito de diferente do esperado. Primeiramente, Af, Am e a pesquisadora decidiram adicionar 4 ao total de 76 para assim, ter as 80 forminhas que necessitavam. Em seguida, ela suscitou uma conversa sobre o porquê dos cálculos de Af não terem chegado ao número 76 , que era realmente a quantidade que estava sobre a mesa. A menina se mostrou resistente a conversar sobre o seu erro, riscando a conta $(76+40)$ que havia feito na sua folha de resoluções. Contudo, quando a pesquisadora disse que errar não era problema, e que fazia parte, Af reconheceu então que tinha somado o número 40 duas vezes. E que o correto para aquela situação era somá-lo apenas uma vez.

Após resolverem a situação anterior, a pesquisadora lançou uma nova situação: representar os cinco grupinhos de quatro de Am e da pesquisadora juntamente com as 40 unidades de Af, de outra forma que não fosse com as forminhas de brigadeiro. Então Af disse que podia substituir as forminhas por dinheiros de papel. A pesquisadora perguntou como isso seria possível. E Af explicou que primeiro trocaria os dois grupos de 20 forminhas por duas notas de 20 cada um. E, em seguida, as suas 40 forminhas por duas notas de 20 reais.

Esta sessão foi finalizada com os participantes representando em uma folha A4 os grupos que cada um deles tinha feito. Af e Am fizeram seus desenhos. A pesquisadora perguntou Am o porquê de ter feito dois desenhos e qual deles era o que representava os seus grupinhos. Ele respondeu que era o segundo, pois no primeiro havia feito apenas 
cinco grupos de dois, em vez de cinco grupos de quatro. Am disse ainda que, daquela forma, não estava certo, pois tinha uma quantidade menor do que a que ele tinha sobre a mesa. Ou seja, ele compreendeu o sentido da multiplicação e foi capaz de representá-lo.

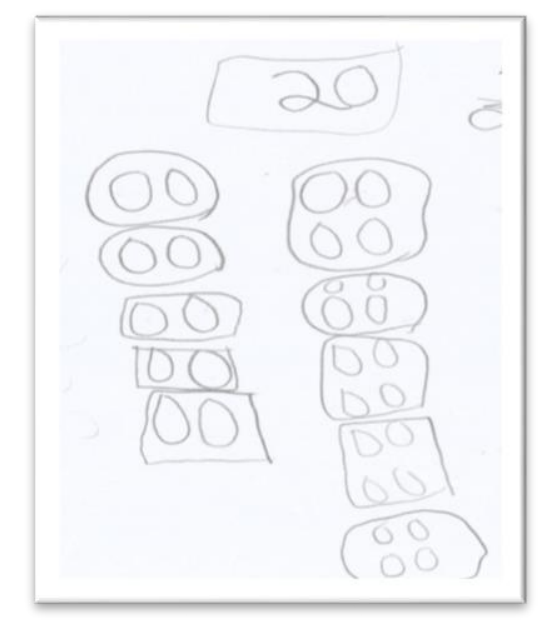

Figura 11. Registro dos grupinhos de Am.

Concluindo, a sexta sessão teve dois destaques. O primeiro deles diz respeito à forma como Am interagiu com os conceitos matemáticos. O menino se mostrou, nas primeiras sessões da pesquisa, bastante resistente a conversar sobre suas resoluções; queria resolver tudo utilizando regras padronizadas, mesmo sem compreender o seu real significado. Também se recusava a fazer registros que não fossem algoritmos. Contudo, nesta sessão, Am não só seguiu a solicitação da pesquisadora, registrando e desenhando suas elaborações, como foi capaz de perceber o próprio equívoco no desenho por ele produzido, se autorregulou quanto a suas resoluções

O segundo destaque desta sessão ficou por conta da troca que Af realizou, das forminhas por dinheiro. Essa ação de Af revelou que, para ela, um número pode ter diferentes significados. Contudo, gerou uma dúvida na pesquisadora, se Af conseguiu 
perceber que ao trocar as forminhas por dinheiro, ela está atribuindo valor de comercialização para cada uma das unidades de brigadeiro.

Vale ressaltar que pela primeira vez, na pesquisa, um dos participantes lançou mão do dinheiro de brinquedo como recurso para suas resoluções. É relevante considerar que este material esteve disponível para o uso sobre a mesa em todas as sessões. Foi observado, ainda, que um dos participantes foi capaz de se autocorrigir, observando o próprio desenho produzido como registro de uma situação-problema.

\subsubsection{Sétima sessão de intervenção}

Data: 17/06/2015 Duração: 43 min

O objetivo desta sessão foi atribuir valor monetário aos brigadeiros e compreender o seu significado, bem como o de manipular valores do Sistema Monetário Nacional compreendendo a sua formação.

\subsection{Desenvolvimento, resultados e discussão da sétima sessão}

Esta sessão se desenvolveu apenas com a participante Af, pois Am não compareceu à escola neste dia. $\mathrm{O}$ foco esteve na atribuição de valor monetário aos brigadeiros. A sessão se iniciou com a leitura das horas. Af indicou que era $8 \mathrm{~h} 50 \mathrm{~min}$. A pesquisadora, no entanto, lhe disse que a hora informada não estava correta. Com isso, a menina se voltou novamente para o relógio, reelaborou a sua leitura e, enfim, informou que era $8 \mathrm{~h} 30 \mathrm{~min}$, o que realmente correspondia à hora indicada no relógio. Em seguida, Af apontou a localização de quando, a contar das $8 \mathrm{~h} 30 \mathrm{~min}$, teriam se passado $40 \mathrm{~min}$. Apesar de tê-la identificado de forma coerente, não soube dizer que hora seria aquela. 
Na sequência, a pesquisadora retomou a sessão da semana anterior, salientando a atitude de Af de trocar as forminhas de brigadeiros por notas de dinheiro. Ela indagou qual seria o significado daquela ação realizada pela menina. O intuito era levá-la a compreender que, com a sua atitude de trocar os brigadeiros por dinheiro, na verdade, ela estava atribuindo valor aos brigadeiros. Com isso, utilizando uma nota de $\mathrm{R} \$ 20,00$, a pesquisadora pediu à menina que conferisse um valor para cada um dos brigadeiros. Foi utilizada a mesma quantia em dinheiro e mesma quantidade de doces utilizados por Af na sessão anterior. A intenção era levar Af à reflexão sobre a situação e sobre a sua ação. A seguir, apresentamos o extrato da sessão que mostra como foi realizada a mediação da pesquisadora.

$\mathrm{P}$ - Olha para a nota que você tem. E olha pra quantidade de brigadeiros que você tem.

Af -20 .

$\mathrm{P}$ - 20. Vamos dar um preço pra cada um. Como você faria isso?

Af - Não sei.

$\mathrm{P}$ - Então vamos fazer de conta que nós vamos vender. Esse já vai ser o nosso primeiro dia de vendas na nossa loja. Nossa fábrica fez e agora nós vamos vender.

Af - Hum.

$\mathrm{P}$ - Todos esses brigadeiros valem 20. Se uma pessoa chegar aqui e disser que quer um. O que a gente vai fazer?

Af - Dá cinco.

$\mathrm{P}$ - Cinco? Vamos testar? Como a gente faz pra ver se a nossa hipótese tá certa?

Af - Não sei.

Neste trecho, podemos perceber que a pesquisadora dá significado à ação realizada por Af na semana anterior, e a encoraja a descobrir o valor de cada um dos brigadeiros. Assim, no fragmento transcrito, é possível identificar as esferas acional e da interação, referentes aos atos da fala, nas proposições da pesquisadora. Ela incitou Af a pensar e a colocar em discussão a sua atividade da sessão anterior. Contudo, no que se refere à resposta dada por Af à pergunta de quanto custava cada brigadeiro, percebemos que a menina ainda se comportava como um sujeito pouco experiente no processo de resolução de problemas. Isso se deve ao fato de não realizar pausas para reflexão, nem mesmo 
expressar outras elaborações para a resolução do problema que lhe foi proposto. Assim que a pergunta lhe foi dirigida, proferiu uma resposta incoerente.

Tendo como base a situação dos vinte reais para os vinte brigadeiros, a pesquisadora sugeriu a Af uma forma de investigar se a sua ideia que cada um custava $\mathrm{R} \$$ 5,00 podia ser factível. Sendo assim, ela sugeriu que espalhassem sobre a mesa 20 forminhas de brigadeiros e sugeriu que fossem distribuindo uma nota de $\mathrm{R} \$ 5,00$ para cada uma das 20 forminhas. A pesquisadora tomou a atitude de sugerir esse procedimento pelo fato de já o terem utilizado em sessões anteriores e também pelo fato Af não ter sugerido nenhum outro procedimento. Logo no início da distribuição das quantias de $\mathrm{R} \$ 5,00$ para cada uma das 20 forminhas, Af interrompeu a distribuição dizendo:

Af - Se for de cinco em cinco, vai dar vinte e cinco!

$\mathrm{P}-$ Como assim?

Af $-5,10,15,20,25$.

$\mathrm{P}$ - Então você acha que não vale 5 ?

Af - Não.

$\mathrm{P}$ - Então qual é o valor de cada um.

Af - Cada um é 1 real.

$\mathrm{P}$ - Cada um é 1 real? Porque você acha?

Af - Não sei.

$\mathrm{P}$ - Então vamos distribuir. Cadê as moedas de 1 real? Eu vou separando as forminhas e em cada uma delas você coloca uma moeda de 1 real.

Neste trecho, diferentemente do anterior, podemos perceber o processo de autorregulação de Af. Assim que começa a distribuição das quantias de R \$ 5,00 entre as forminhas, percebe que está trabalhando com os múltiplos de cinco. Como Af já possui a competência da contagem desses múltiplos, ela consegue realizá-la internamente e, em seguida, realiza a mesma contagem por meio da fala. Naquele momento, ela tomou consciência de que não havia a possibilidade de que cada brigadeiro custasse $\mathrm{R} \$ 5,00$. Dessa forma, ela ultrapassaria o valor de $\mathrm{R} \$ 20,00$ proposto para a situação-problema, e para o valor total dos 20 brigadeiros. Retomando um dos nossos objetivos específicos da pesquisa, Af foi capaz de perceber a razoabilidade ou não de um cálculo. Isso levou Af a 
ter de pensar em um novo valor para os brigadeiros, como descreveremos a seguir. Neste trecho, também identificamos que, como o objetivo da fala de Af era o de explicitar o seu pensamento, temos a esfera da informação, referente aos atos da fala, presente nas proposições da menina.

A nova hipótese apresentada por Af foi, então, a de que cada brigadeiro custaria $\mathrm{R} \$$ 1,00. Como não soube justificar o porquê de sua nova proposta, a pesquisadora sugeriu que realizassem o mesmo procedimento de distribuição anterior - os $\mathrm{R} \$ 5,00$ entre as 20 forminhas, para o valor de $\mathrm{R} \$ 1,00$. Ao término da distribuição, Af contou cada uma das forminhas e descobriu que sua hipótese de que os brigadeiros custariam $\mathrm{R}$ \$ 1,00 estava correta. Ela registrou, ainda, no papel, o que havia sido feito na mesa, com as forminhas e o dinheiro, atendendo ao método de intervenção que visava à passagem da representação para o registro.

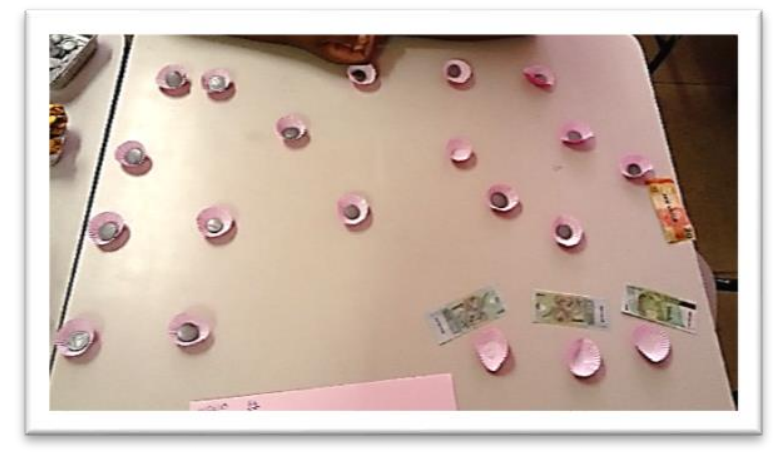

Figura 12. Moedas e notas distribuídas nas 20 forminhas de brigadeiro.

A pesquisadora atentou para uma particularidade na distribuição de Af. Ela atribuiu a algumas forminhas o valor de 1 centavo. Perguntada o porquê, Af disse que era por causa da falta de mais moedas de $\mathrm{R} \$ 1,00$. Essas moedas, portanto, deveriam ser consideradas como valendo $\mathrm{R} \$ 1,00$, segundo Af. A pesquisadora convidou, então, Af a trocar essas moedas de 1 centavo por outras, na caixa de reserva, de modo que pudesse formar com outras moedas, o mesmo valor de $\mathrm{R} \$ 1,00$. Em um primeiro momento, Af se 
espantou com o fato de todas as moedas da caixinha de reserva serem de centavos. O que indicou a sua incompreensão a respeito da formação dos valores do real. Num segundo momento, porém, aceitou a proposta da pesquisadora e formou grupos de $\mathrm{R} \$ 1,00$ utilizando moedas de valores menores. Assim, Af formou R $\$ 1,00$ de três formas diferentes: 1) com duas moedas de $\mathrm{R} \$ 0,50 ; 2)$ com 4 moedas de $\mathrm{R} \$ 0,25 ; 3)$ com $\mathrm{R} \$ 8$ moedas de $\mathrm{R} \$ 0,10$ mais 4 moedas de $\mathrm{R} \$ 0,05$.

A pesquisadora solicitou a Af que verificasse e registrasse cada uma das formas utilizadas por ela para formar $\mathrm{R} \$ 1,00$. Af fez o que lhe foi solicitado, demonstrando ter compreendido a formação de um número, por diferentes maneiras. Apesar desses avanços, um impasse foi identificado: Af desprezou as moedas de $\mathrm{R} \$ 0,01$. Ao ser perguntada sobre o porquê de não as ter utilizado, disse que elas não tinham valor.

Evidenciamos, nesta sessão, a dificuldade de Af em compreender a formação do valor $\mathrm{R} \$ 1,00$. Essa dificuldade já havia sido apontada na primeira fase desta pesquisa, a da avaliação psicopedagógica. Observamos, no entanto, que, ao ser impelida a usar outras moedas, Af começou a tomar consciência de que os valores de real podem ser formados de inúmeras maneiras. Uma dificuldade, portanto, permaneceu: Af disse que o uso do R \$ 0,01 é dispensável, pois ele não tem valor.

\subsubsection{Oitava sessão de intervenção}

Data: 24/06/2015 Duração: 40 min.

O objetivo desta sessão foi atribuir valor às unidades de brigadeiros, levando em conta o preço dos ingredientes necessários para o seu preparo. Para realizar as atividades propostas, os materiais utilizados foram: encartes de supermercado para pesquisar o valor 
dos ingredientes; dinheiro de brinquedo e palitos de picolé, para realizar cálculos; e folhas de papel A4 para registros.

\subsection{Desenvolvimento, resultados e discussão da oitava sessão}

Esta sessão se desenvolveu em torno da pesquisa do valor de comercialização dos brigadeiros. Foram considerados, para determinar esse valor, os custos com todos os ingredientes necessários para o preparo dos doces. Iniciamos as discussões da sessão por meio do relato de Af para Am, sobre o que havia acontecido na semana anterior (sétima sessão), sessão na qual Am havia faltado. Af disse a Am que a pesquisadora retomou a sua ação (realizada na sexta sessão) de trocar vinte forminhas de brigadeiro por vinte reais em dinheiro e que isso serviu de estratégia para a definição do valor de venda dos brigadeiros que produziriam.

Af - Foi assim. Eu peguei. NÃO! A gente descobriu o valor do nosso brigadeiro.

Am - Hã?

Af - Que é 4 reais.

$\mathrm{P}$ - Quatro?

Am - huuum?

P - Você não tinha feito que tinha dado um real pra cada um?

Af-AI, ERA! @ @

P - Então, Am, se os brigadeiros deram 20 reais no total, quanto que era?

Am - Já sei. Cada brigadeiro que você quer né?

$\mathrm{P}-\mathrm{E}$.

Am - Então cada brigadeiro era 1 real então quer comprar 20, então vai dar 20.

Podemos observar, neste extrato da transcrição, a presença da esfera da informação nos atos da fala de Af. A menina visava, naquele momento, descrever o que haviam feito, sem se preocupar se Am compreendia o que ela estava apresentando. Contudo, ao informar o valor do brigadeiro, ela atribui um número diferente daquele que realmente havia manipulado na sessão anterior e que era de R\$1,00. Esse dado nos apontou para uma dificuldade que Af apresentou em várias sessões, dificuldades em guardar informações e 
detalhes de uma sessão para a outra. Em geral, sempre que a pesquisadora the pedia para falar sobre as sessões anteriores, ela alegava não se lembrar do que haviam feito. Neste caso, Af simplesmente não se lembrou do valor que ela mesma havia atribuído ao brigadeiro.

Com a interferência da pesquisadora, porém, Af afirmou se lembrar de que o valor do brigadeiro era um real e não quatro. Naquele momento, a pesquisadora se voltou para Am, e se valeu da esfera acional dos atos da fala para levar o menino a perceber como foi que o valor de 1 real foi atribuído, e para que pudesse perceber que o valor de quatro reais realmente não poderia atender aos critérios estabelecidos tanto por Af como pela pesquisadora.

O interessante é que ao apresentar a pergunta "Então, Am, se os brigadeiros deram 20 reais no total, quanto que era?", a pesquisadora, não deixa claro, com a sua fala, o que deseja saber de Am. Apesar disso, ele entendeu que a proposta da pesquisadora era saber o valor unitário dos brigadeiros. Apesar de Am ter informado que cada doce custaria 1 real e o total seria 20 reais, não podemos concluir se o menino chegou a essa conclusão por meio de algum cálculo mental ou porque a própria pesquisadora já havia dito anteriormente que cada um custava 1 real.

Após ter sido atribuído o valor de $\mathrm{R} \$ 1,00$ às unidades de brigadeiro, pesquisadora questionou se esse valor era coerente, incitando os participantes a pensar sobre algumas variáveis que teriam relação direta com o preço do produto, como, por exemplo, o preço dos ingredientes. Am disse que o sabor e o tamanho também interferiam na definição do preço. Sendo assim, ela propôs que retomassem a receita inicial, para que pudessem relembrar seus itens e, em seguida, pesquisar em encartes de supermercado o preço desses produtos. 
De posse de alguns encaretes de supermercado, a pesquisadora, Af e Am identificaram neles os ingredientes constituintes de uma receita de brigadeiro e observaram o peso expresso em cada umas das embalagens dos produtos e pesquisaram o preço de cada um dos ingredientes. Primeiro, tiveram que definir quais deles seriam comprados, associando a quantidade necessária para o uso na receita e a quantia expressa na embalagem dos produtos. Então, decidiram utilizar, para os cálculos, a margarina de 250 gramas que custava $R \$ 2,89$, o achocolatado em pó de 400 gramas no valor de $R \$ 3,59$, a lata de leite condensado de 395 gramas por $\mathrm{R} \$ 2,99$ e o pacote de chocolate granulado de 150 gramas que custava $\mathrm{R} \$ 1,59$.

Após definirem os produtos que deveriam compor o preparo da receita, cada um dos participantes escolheu as suas estratégias para chegar ao valor da compra desses produtos. Af disse que registraria a sua conta no papel, mas que a resolveria com o auxílio dos palitos de picolé. Am resolveu utilizar o dinheiro na sua resolução. Af montou um algoritmo da adição com os valores dos ingredientes. Ela apresentou como resposta o valor $\mathrm{R} \$ 9,64$.

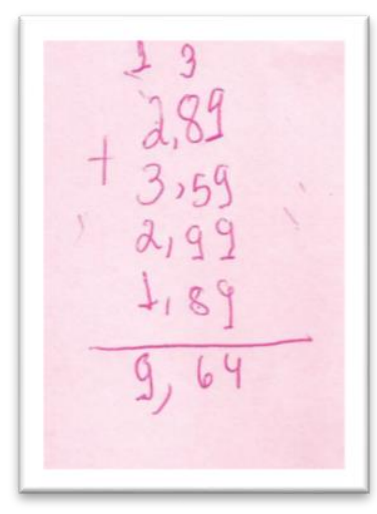

Figura 13. Algoritmo de Af 
Analisando o algoritmo apresentado por Af, vimos que seus cálculos não condiziam com o verdadeiro resultado da conta, que era de 11,36. Observamos que Af demonstrou saber a regra da adição com números decimais. Posicionou vírgula abaixo de vírgula, começou a calcular da direita para a esquerda como diz a regra. Contudo, esse conhecimento não foi suficiente para que ela chegasse à resposta correta. Esse dado confirma o que já foi apontado anteriormente - que saber a regra não significa que o indivíduo tenha domínio da lógica subjacente às operações.

Am, por sua vez, distribuiu sobre a mesa os valores dos ingredientes, utilizando dinheiro. A certa altura da distribuição, disse que estava com dificuldades. A pesquisadora observou que a dificuldade de Am decorria da forma como ele estava representando os valores. 2,89, por exemplo, estava representado com 1 nota de $\mathrm{R} \$ 2,00$ e 1 moeda de $\mathrm{R} \$$ 1,00 , totalizando $\mathrm{R} \$ 3,00 ; \mathrm{R} \$ 1,89$ foi representado por duas moedas de 1 real, totalizando $\mathrm{R} \$ 2,00$. Vendo que estava cada vez mais complicado representar os valores, Am desistiu de usar o dinheiro, para fazer uma conta no papel. Ele se recusava a representar os valores quebrados, pois segundo ele, e também Af, no comércio trabalha-se com valores redondos. Ou seja, estava familiarizado com essa forma de representação e não uma que requeria o uso de centavos.

A pesquisadora, notando que Am estava com muita dificuldade e que a sessão já chegava ao fim, sugeriu que encerrassem a atividade e reiniciassem na próxima semana, considerando a estratégia de Am. O menino se mostrou favorável à sugestão e, com isso, finalizaram os trabalhos. Esta sessão evidenciou uma dificuldade dos indivíduos: a incompreensão dos números decimais. Am, por exemplo, não conseguiu representar os valores dos ingredientes, com o dinheiro, por não saber que deveria fazer uso de unidades menores, que não fossem números inteiros. Af, por sua vez, demonstrou saber a regra dos 
cálculos com números decimais; contudo, resolveu, de forma incorreta, o algoritmo que ela mesma montou com esses números.

\subsubsection{Nona sessão de intervenção}

Data: 01/07/2015 Duração: $41 \mathrm{~min}$.

O objetivo desta sessão foi trabalhar com dinheiro e perceber a formação dos valores de Real. Para o desenvolvimento das atividades, foi utilizado, como material concreto, o dinheiro de brinquedo (cédulas de papel e moedas de plástico).

\subsection{Desenvolvimento, resultados e discussão da nona sessão}

A nona sessão se desenvolveu a partir de situações-problemas referentes às relações de dinheiro, enfatizando a composição e a decomposição de valores da moeda Real. Partimos da dificuldade apresentada por Am, na sessão anterior, em relação à realizar a formação, com moedas e notas, de pequenos valores como $\mathrm{R} \$ 2,89$ e $\mathrm{R} \$ 1,59$. Foram evidenciados a incompreensão do uso do 1 centavo e o manejo dos números decimais.

Iniciamos a nona sessão relembrando que, ao final da oitava sessão, decidimos retomar a soma dos valores dos ingredientes de uma receita de brigadeiro. Foi lembrado que, na sessão anterior, Af fez seus cálculos no papel e obteve como resposta o número 9,64. E que Am, por sua vez, optou por utilizar o dinheirinho para resolver a situação proposta. No entanto, ao dispor sobre a mesa o valor de cada um dos ingredientes, disse que estava com dificuldade.

Após essa conversa, começamos, então, a desenvolver a estratégia de Am, de forma que juntos, pudéssemos conversar a respeito das dúvidas. Primeiramente, representamos sobre a mesa os valores de $\mathrm{R} \$ 3,59$, referentes ao achocolatado; $\mathrm{R} \$ 2,99$ referentes ao leite 
condensado; $\mathrm{R} \$ 2,89$, referentes à margarina; e 1,89, que era o valor do chocolate granulado. Esses números, por decisão de Af e Am, foram arredondados, pois, segundo eles, o comércio não devolve $\mathrm{R} \$ 0,01$.

Sendo assim, para representar o valor de 3,59, Am colocou uma nota de 2 reais, 1 nota de 1 real e duas moedas de $\mathrm{R} \$ 0,50$. Disse que teria que deixar passando do valor, mas que poderia receber troco. Af, não concordando com a representação de Am, disse que era melhor que ele substituísse as duas moedas de $R \$ 0,50$ por uma $R \$ 0,50$ e outra de $R \$$ 0,10. Dessa forma, ele teria $\mathrm{R} \$ 0,60$, que era muito mais próximo dos $\mathrm{R} \$ 0,59$.

O curioso da ação, tanto de Am como de Af, de arredondar os valores dos produtos, foi que havia moedas suficientes à disposição deles para representar os $R \$ 0,59$ por exemplo. No entanto, ficaram presos ao uso social que faziam do dinheiro no seu dia a dia. Nem mesmo sendo instigados a usar as moedas de $\mathrm{R} \$ 0,01$ admitiam a possibilidade de seu uso. Outra curiosidade desse fato, foi a competência demonstrada por Af, ao questionar e sugerir mudanças na representação de Am. Ao sugerir que ele arredondasse R \$ 3,59 para $\mathrm{R} \$ 3,60$ e não $\mathrm{R} \$ 4,00$, como fez Am, Af indica que ter consciência da distância entre os números, o que lhe permite propor arredondamentos bem precisos.

A pesquisadora indagou a Af e Am sobre a atitude de arredondar os valores. Cada um dos participantes apresentou justificativas diferentes. Pela riqueza das interlocuções, apresentamos, a seguir, esse trecho da transcrição da sessão:

$\mathrm{P}$ - Por que não tem como deixar 2,89?

Af - Porque não existe 1 centavo.

$\mathrm{P}$ - Mas isso daqui não é um centavo? \{ $\mathrm{P}$ aponta para as moedinhas, de brinquedo, no valor de 1 centavo

$\mathrm{P}$ - Vocês, nunca viram moeda de 1 centavo?

Am - Eu já.

Af - Não existe. Só de um real. Não 1 centavo.

$\mathrm{P}-\mathrm{O}$ que você acha? Não existe moeda de 1 centavo?

Am - Existir, existe, só que não se usa mais. Não tem valor.

$\mathrm{P}$ - Se eu chegar com uma moeda de 1 centavo no mercado, eu não vou comprar com ela?

Af - Não. 
Am - Não, por que não aceita, só de um real.

Esse trecho revelou que as dificuldades na Matemática possuem um significado e, no caso descrito aqui, a dificuldade decorria da incompatibilidade da forma como utilizavam o dinheiro no seu cotidiano e a forma como estava sendo solicitada na sessão de intervenção.

Na sequência, a pesquisadora indicou que os participantes formassem os valores da maneira que desejassem. Arredondaram, então, todos os valores dos produtos, para, em seguida, procederem à adição. No momento da resolução, porém, Am disse que estava com dificuldade. A pesquisadora sugeriu a ele somar primeiro as notas e escrever o resultado e depois contar as moedas e também escrever os valores. Com isso, teria dois números apenas para somar, o que poderia resultar em uma estratégia de cálculo que fosse mais fácil.

Am, não seguiu as recomendações da pesquisadora, mas Af sim. Ela contou as notas e disse que havia 5 reais. A pesquisadora pediu a Am que contasse as moedas. Ele disse que sabia contar, mas que não estava com vontade. Af, então, começou a contar as moedas e chegou a um total de $\mathrm{R} \$ 4,40$. Ao somar os valores das notas e das moedas, disse que o total era $\mathrm{R} \$ 9,40$. Vale ressaltar que Af fez a adição das notas e das moedas, por meio de cálculo mental, não necessitando de realizar registros no papel. Por fim, a pesquisadora comparou os resultados de Af e Am e informou que eram parecidos, mas que tinham resultados diferentes. Assim, decidiram investigar o que havia acontecido, no entanto, deixariam para a próxima sessão.

Nesta sessão, percebemos dois dados muito importantes. Primeiramente, os participantes, sempre que se deparavam com um determinado valor terminado em 9, arredondaram os valores para mais. Acreditamos que, por trás dessa situação, está o uso social de arredondar os valores, por conta de uma ausência real de moedas de 1 centavo em 
circulação no comércio. Isso engendrou, em Af e Am, crenças de que 1 centavo não existia ou que não tinha valor.

\subsubsection{Décima sessão de intervenção psicopedagógica}

Data: 15-07-15 Duração: 34 minutos

O objetivo desta sessão foi retomar o cálculo com números decimais, realizado na sessão anterior, e perceber a formação de números decimais e a lógica de suas operações. Nesta sessão, foram utilizados como materiais de apoio, papel, canetas coloridas e dinheiro de brinquedos disponibilizados em uma caixa sobre a mesa. Com o papel os participantes realizam registro de algoritmos; com o dinheiro realizaram adições e subtrações, além de formarem valores.

\subsection{Desenvolvimento, resultados e discussão da décima sessão}

Nesta sessão, ficou evidente a dificuldade de Af e Am em relação ao manejo dos números decimais. Evidenciamos conflitos no que se referia à formação dos números, principalmente na compreensão da diferença entre a parte inteira e a decimal. Salientamos também a dificuldade da pesquisadora em perceber o significado do procedimento proposto por Af para representar o valor $\mathrm{R} \$ 11,36$.

Como de costume, a sessão teve início com a pesquisa da data e da hora. Diferentemente de outras sessões, nas quais Am e Af deviam descobrir as horas de início da sessão e quando se completaria 40 minutos, desta vez dissemos a hora que a sessão deveria terminar e, a partir dessa informação, os participantes teriam que investigar quantos minutos duraria a sessão. Cada um apresentou uma resposta diferente; Am 35 
minutos, Af 25 minutos. Ambos justificaram que contaram de 5 em cinco no relógio para chegar à resposta.

A pesquisadora propôs que contassem novamente, desta vez junto com ela, utilizando esse mesmo procedimento de contagem de cinco, para talvez resolver o problema das diferenças de resultados. Antes que começasse a contar, ela incitou os participantes a lhe apontarem no relógio onde deviam começar a contagem. Dessa forma, Af percebeu que tinha iniciado a sua contagem no número sete do relógio quando na verdade deveria ter começado pelo seis. Ou seja, por conta do seu ponto de partida, a sua contagem final teve cinco minutos a menos que a de Am.

Ainda sobre a leitura das horas, Am apresentou uma fala que demostra o seu processo de autorregulação quando ele diz: "Nós vamos sair 9h40. Não, não! Nós vamos sair em 40 minutos". Ao se observar as outras sessões, pode-se identificar que anteriormente Am não conseguia se descentrar do número representado para identificar a hora. Em outras palavras, se o ponteiro dos minutos estivesse sobre o numeral, ele dizia que era 10 horas e não que aquela representação indicava 50 minutos. Nesta sessão, porém, ressaltou que 9 h40min era diferente de 40 minutos, ou seja, ele percebeu que havia outros fatores a se considerar nessa identificação da hora.

Na sequência, a pesquisadora apresentou para Af e Am o registro da adição 2,89 + $3,59+2,89+1,89$ e os incitou a lembrar em que circunstâncias aquela operação foi realizada. Sendo assim, Af e Am afirmaram que juntaram os valores dos ingredientes (leite condensado, chocolate em pó, margarina e chocolate granulado) que compunham uma receita de brigadeiro, para descobrir quando se gastaria para produzir brigadeiros.

A pesquisadora salientou, no entanto, que cada um dos participantes resolveu aquela adição por procedimentos diferentes - Af utilizou palitos para contagem e registro no papel, Am, por sua vez, utilizou dinheiro de brinquedo e registro no papel. Quando ela 
perguntou se os resultados de cada um foram iguais ou diferentes considerando que o algoritmo resolvido por Am teve como resposta 9,40 e o de Af 9,64, Am apresentou a seguinte proposição: “NÃO! É É SIM! SÓ QUE MUDOU OS CENTAVOS!” (...) A parte dos reais é igual, mas os centavos não".

Vemos no trecho acima, duas esferas dos atos da fala presentes na proposição de Am. O primeiro, referente à esfera da avaliação. Isso porque, Am realizou um julgamento sobre os resultados dos cálculos dele e de Af, no qual justificou que os seus resultados eram iguais. Em seguida, a esfera do ato da fala passou a ser a da informação, uma vez que Am explicou o porquê de considerar que as respostas dele e de Af fossem iguais. Esse posicionamento de Am nos sugeriu uma incompreensão do registro dos números decimais. Am desconsiderou a parte decimal desses números na hora de compará-los e determinar qual deles era o maior.

A pesquisadora informou, no entanto, que o fato dos centavos (parte decimal do número) ser diferente, fazia com os números 9,40 e 9,64 fossem diferentes. Com isso, perguntou aos participantes porque eles achavam que chegaram a respostas diferentes se utilizaram os mesmos números. Apesar disso, não obteve resposta. Sendo assim, perguntou como seria possível descobrir o real resultado desse algoritmo e Am lhe apresentou como solução para o problema: refazer o cálculo. Af e Am decidiram resolver o algoritmo no papel e resolveram os cálculos verbalizando o que estão fazendo. Fizeram uso de regras utilizadas no meio escolar como, por exemplo: começar da direita para, subir a dezena formada a partir do cálculo na casa das unidades, para a casa das dezenas. Ao final da resolução, encontram um resultado para o algoritmo que diferia dos dois resultados encontrados por eles, anteriormente.

Naquele momento, a pesquisadora perguntou a Af e Am como fazer para descobrir o real resultado para aquele algoritmo. Isso levou Af e Am a reverem o registro que 
acabaram de fazer. Af, no entanto, mostrou-se inconformada, pois ao rever ela não percebeu nenhuma diferença. Am ainda tentou encontrar algo que pudesse justificar um possível erro de cálculos no algoritmo, mas desistiu quando Af afirmou que não havia erro algum. A pesquisadora observou a inquietação dos participantes e iniciou uma reflexão sobre o uso de dinheiro no dia a dia. Porém, foi subitamente interrompida por Af. A menina pediu o dinheiro de brinquedo que se encontrava sobre a mesa e propôs conferir o resultado do algoritmo passo a passo utilizando o dinheiro de brinquedo como apoio para a contagem. A seguir, temos o trecho dessa análise com suporte do material.

Af - Ô, aqui (?) nessa fileira tá errada, primeiro a gente não pode começar de contar dessa fileira que tá errado. Tem que começar do nove.

$\mathrm{P}$ - Não pode começar a contar de qual fileira, Af?

Af - Começa a contar dessa fileira.

Am - Hum?

$\mathrm{P}$ - Por que não pode?

Af - Porque tem que saber o resultado dessa para comparar com essa. \{Af se refere a regra de começar a resolução da adição na direção da direita para a esquerda\}

$\mathrm{P}$ - Por qual motivo eu tenho que começar por aquela?

Af - motivo nenhum. Porque a gente tem que saber o resultado dessa. Por que (?) era 63.

Em primeiro lugar, é necessário refletir sobre as esferas dos atos da fala, presentes nesse trecho. Na fala de Af vemos muito presente a esfera da informação. Sua proposição é toda no sentido de justificar um possível erro na resolução do algoritmo. Ela informou qual foi o erro. Nesse recorte, a pesquisadora se colocou em dois momentos, no primeiro, a sua fala nos remeteu à esfera contratual dos atos da fala, pois buscou apenas regular a conversa com Af, mas, em seguida, apresentou uma fala que se situou na esfera da interação, por desafiar Af a justificar a sua resposta de que teria que começar da fileira que ela estava indicando. Esse trecho ainda nos revelou o quão presente é o uso das regras dos algoritmos nas resoluções escolares, pois essa foi a primeira estratégia a qual os participantes aderiram. Isso mostrou também, o quanto essas regras são aplicadas sem a devida compreensão da sua lógica. O que reforçou a importância de se trabalhar a reflexão dos 
processos de construção dos conceitos matemáticos com os alunos, de forma que façam sentido o seu uso no dia a dia.

Uma ação de Af, relativa ainda a esse algoritmo ao qual nos referimos, ao longo desta discussão da sessão, refere ao modo como Af representou, por meio do dinheiro de brinquedo, o número 11, 36 (resultado do algoritmo resolvido por Af e Am). Para formar esse número, Af começou juntando moedas de 50 ou de 25 para formar 1 real. A menina foi juntando esses valores e, assim, foi apresentando o resultado de suas formações. $\mathrm{O}$ primeiro deles foi $\mathrm{R} \$ 4,50$, em seguida $\mathrm{R} \$ 5,50$, depois $\mathrm{R} \$ 9,00$. Ela foi pedindo a Am que contasse as moedas de modo que ela ficasse apenas com a soma dos valores separados por Am. Quando Am lhe entregou mais moedas e o total chegou a $\mathrm{R} \$ 13,00$, a pesquisadora sinalizou que ela já tinha ultrapassado o valor de 11,36 valor. Af, no entanto, pediu para continuar a separar as moedas.

A pesquisadora, não compreendendo o procedimento de Af, pediu a ela que explicasse o que estava fazendo, uma vez que não compreendia o fato de Af querer representar R\$11,36 e já ter separado $\mathrm{R} \$ 13,00$, número que extrapolava a parte inteira do referido número que era 11 . Af pediu à pesquisadora que esperasse ela terminar, e pediu a Am que continuasse a juntar as moedas para ela continuar somando os valores. Quando a contagem de Af chegou a 18, a pesquisadora insistiu que ela lhe explicasse o que estava fazendo. O pedido da pesquisadora foi em vão, pois a menina seguia em sua proposição até que chegaram ao valor de $\mathrm{R} \$ 39,00$. Nesse momento, Af se voltou para o registro 11,36, no papel, e começou a realizar algumas subtrações no valor de $\mathrm{R} \$ 39$. A seguir reproduzimos o trecho das interlocuções em que ela realiza esse procedimento.

Am - 30, 31, 32, 33, 34, 35, 36, 37, 38, 39.

$\mathrm{P}$ - Tá.

Af - Peraí. Não conta. Com esses daqui dá quanto?

Am - 39 .

Af - Não, tirando os dez daqui?

$\mathrm{Am}-\mathrm{E}$. 
$\mathrm{P}$ - 39 menos 10 daria quanto?

Am - 30 .

$\mathrm{P}-39$ menos 10 ?

Am - Não! Éééé...

Af - (?)

Am - 29 .

P - Tá 29.

Af - 29?

Am - é.

Af - (?)

Am - (?)

$\mathrm{P}-\mathrm{E}$ agora, o que você fez?

Af - Tem 29.

Am - Vai dar 36.

Af -35 ?

Am - 36 .

Af - 36? Pronto.

P - TRINTA E SEIS? 29 com 5 ?

Af - Espera.

$\mathrm{P}-29$ mais $5 \ldots$

Am - 29 mais 5 é 35 .

Af -34

P - TRINTA E QUATRO?

Af - É aí bota um real daqui, aqui, e tem os 36, aí bota os 11 reais.

Neste trecho, duas esferas dos atos da fala se revezaram. Uma é a esfera da interação, percebida principalmente nas interlocuções entre Af e Am a respeito de quanto iriam tirar de cada número, em que um complementava a fala do outro. A outra esfera refere-se à esfera acional, que se mostra no engajamento dos participantes durante as resoluções. A frase final revela a intenção de Af ao realizar uma contagem que ultrapassava 11 e que era correspondente a parte inteira do número. Ou seja, para Af tanto a parte inteira (11) como a parte dos decimais (36) poderiam ser, igualmente representadas, pelos valores inteiros do dinheiro. O que nos leva a concluir que Af desconhecia a diferença entre a parte inteira e decimal dos números. 


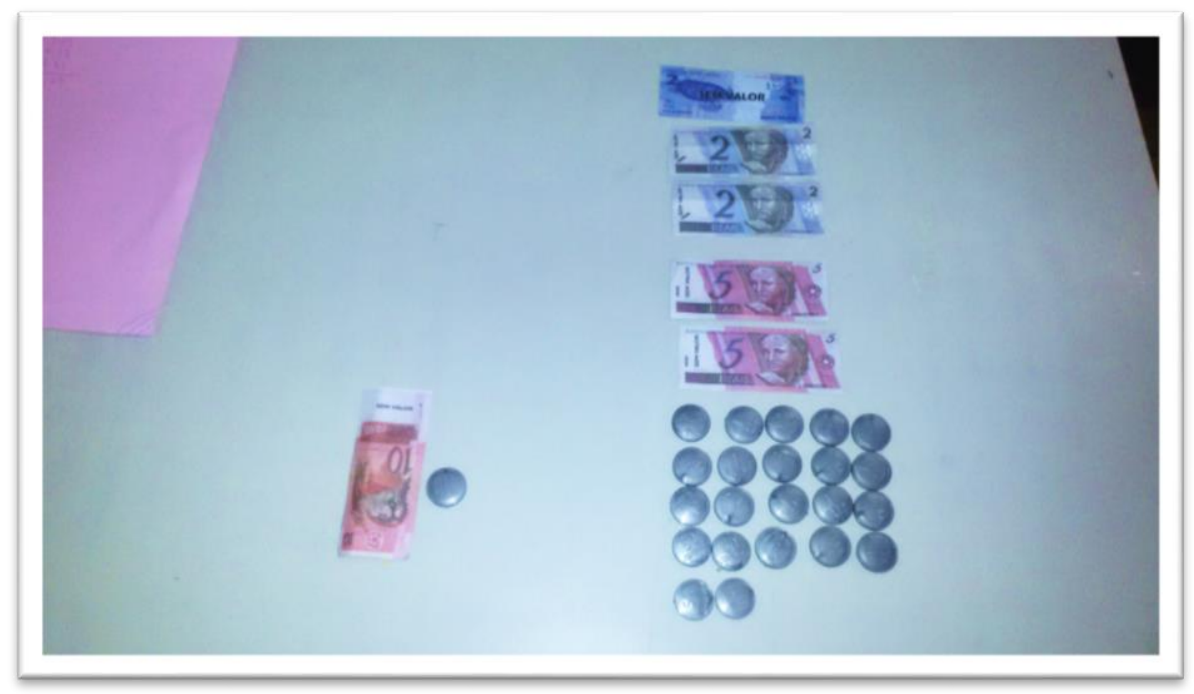

Figura 14. Representação da participante Af, do valor $R \$ 11,36$

Portanto, concluímos esta sessão evidenciando que Af demonstrou dificuldade na compreensão entre parte decimal e parte inteira do número. Evidenciamos, ao mesmo tempo, o desenvolvimento da competência da formação de valores de real que havia sido uma dificuldade encontrada na fase da avalição. Evidenciamos ainda, a dificuldade da pesquisadora, ao longo da atividade, em não perceber o sentido da ação de Af. O que mostra a necessidade de ouvir o indivíduo para identificar os significados que ele mesmo atribui à sua produção.

\subsubsection{Décima primeira sessão de intervenção psicopedagógica.}

Data: 05-08-15 Duração: 40 min e 58 segundos

O objetivo desta sessão foi registrar os valores presente no algoritmo 2,89+3,59+2,99+1,89 com dinheiro de brinquedo. Comparar a representação no material concreto e a representação semiótica com os algarismos. 


\subsection{Desenvolvimento, resultados e discussão da décima primeira sessão.}

Esta sessão foi realizada apenas com a presença de Am, devido à ausência de Af. O foco das atividades desenvolvidas foi a retomada do algoritmo $2,89+3,59+2,99+1,89$ $=11,36$ referente à soma dos valores dos ingredientes da uma receita de brigadeiro e o seu registro por meio de símbolos. Cada numeral foi representado no dinheiro, em seguida registrado o seu valor no papel. Após o registro, a pesquisadora e o participante conversaram sobre essas representações e os registros. Essas conversas permitiram que Am pudesse refletir sobre a formação dos números e, principalmente, sobre a diferença entre os conceitos dos valores absolutos e relativos dos números.

Iniciamos a sessão com a leitura das horas no relógio analógico e pudemos perceber o quanto Am leu a hora de início corretamente e identificou a hora que terminaria a sessão, levando em conta que duraria 40 minutos. Desse modo, ele indicou que estava desenvolvendo a construção da leitura das horas.

Quanto às atividades com dinheiro, nossa primeira ação foi: retomar o algoritmo de $2,89+3,59+2,99+1,89=11,36$; com o qual trabalhamos na sessão anterior. Ao se deparar com o referido algoritmo, Am se engajou em conferir se os tais valores presentes no algoritmo apresentado pela pesquisadora se referiam mesmo aos preços dos ingredientes de brigadeiros. Satisfeita essa condição, a pesquisadora apresentou a situação-problema da sessão:

P - Tá. Sabe o que a gente tinha que fazer? A gente encontrou o preço para esses produtos todos aqui. Qual foi o valor?

Am -11 reais e 36 centavos.

$\mathrm{P}-11$ reais e 36 centavos? Tá. Vamos representar novamente isso, só que no dinheiro?

Diante da proposição da pesquisadora, Am começou a representar cada um dos valores do algoritmo. O procedimento adotado por Am, para representar os números, foi o 
seguinte: retirar da caixa reserva, disposta sobre a mesa, a quantidade necessária para representar a parte inteira de cada número. Em seguida, representou as dezenas desse número e por fim as unidades sempre nessa mesma ordem. Durante a organização desses valores, a pesquisadora instigou o menino a realizar outros procedimentos que pudessem auxiliar a organização de seu pensamento. Como no trecho a seguir:

\{Am manipula as moedas para representar o valor que lhe foi solicitado: 2,89$\} \mathrm{P}-$ vai falando, o que você tá contando aí.

Am - 10, 20, 30, 40... 50, 60, 80. 80! É 2,89?

$\mathrm{P}-2,89$ ! Quantas moedas você tem ali mesmo? Conta novamente. \{P não indica $\mathrm{o}$ erro na contagem feita por Am, mas pede para que reconte, para perceber a sua própria inconsistência\}.

Am-10, 20,30,40, 50,60,70@@.

70 ! $\mathrm{P}$ - Você tinha dito que tinha quanto?

Am -80 .

$\mathrm{P}-\mathrm{O}$ que será que aconteceu?

$\mathrm{Am}-\mathrm{Eu}$ contei um a mais.

Nesse trecho, pudemos identificar duas esferas principais referentes aos atos da fala. Nas falas da pesquisadora, o primeiro deles diz respeito à esfera da interação, na qual podemos perceber os atos de desafiar e contestar. O segundo refere-se à esfera acional, na qual vemos como principais atos o de propor e incitar. Já nas falas de Am, identificamos a esfera da informação caracterizada pelos atos de confirmar e retificar. Nesse extrato, destaca-se a forma de mediação da pesquisadora, que não apontou o erro cometido por Am, mas o induziu a identificar o que estava incorreto. Am, por sua vez, indicou que havia contado uma vez a mais, o que na verdade não aconteceu, ele apenas trocou o último número da sequência, em vez dizer 70 disse 80 .

Na sequência desse trecho, destacamos outro que se refere ao procedimento de representação do número 2,89. A pesquisadora e Am conversaram sobre a formação desse número e Am explicou que o 2 fazia parte dos reais e o 89 referia-se aos centavos. Com isso, ela indagou Am sobre qual desses números era o maior e ele apontou o 2 por ser da parte dos reais. No entanto, quando questionado especificamente sobre o 89, apontou o 9 
como o número maior. Nessa hora, a pesquisadora pediu que Am retomasse a sua representação com o dinheiro. Sua intenção era fazê-lo rever sua representação e, com isso, Am poderia perceber que, apesar de ver registrado o número 8, na verdade ele representa 80 unidades.

Compreender que o oito neste caso é maior que o nove, não se mostrou como uma tarefa simples. Contudo, as comparações sugeridas pela pesquisadora entre a representação e o registro foram fundamentais para que Am pudesse compreender o conceito em jogo. Esses mesmo procedimentos foram repetidos para os numerais 3,59, 2,99 e 1,89. No momento que Am representou 3,59 e lhe foi perguntado qual dos números era o maior e qual o menor, as respostas foram semelhantes ao exemplo anterior do número 3,59. Em primeiro lugar, ele afirmou que o três era o maior porque fazia parte dos reais e que o 59 era menor porque fazia parte dos centavos. Em seguida, ele disse que o nove era maior do que o cinco no 59. Contudo, ao ser solicitado novamente a comparar a representação e o registro, afirmou que o cinco era maior porque era cinquenta.

Observamos que nos próximos números representados - 2,99 e 1,59 -, a resposta de Am em relação a qual deles é maior no número todo, se mantém sendo maior aquele que ele aponta como parte dos reais; e menor, a parte dos centavos. Porém, quando a parte dos centavos é tomada como unidade de análise, ele afirma que o primeiro nove é maior do que o segundo nove, no número 2,99. Ou seja, o primeiro nove vale noventa; e o segundo, apenas nove.

Como já dissemos, em todas as representações Am utilizou o mesmo procedimento para formar os números, no número 1,89 temos uma particularidade quando ele deseja representar a parte dos centavos. Primeiramente Am pega oito moedas de 10 centavos e dispõe sobre a mesa. Em seguida, pega da caixa reserva uma moeda de 5 centavos e 3 moedas de 1 centavos. Nesse momento, Am totaliza 88 centavos e se vê com um problema 
para chegar aos 89, pois não tem mais moedas de 1 centavo para adicionar aos 88. Quando a pesquisadora decidiu sugerir um procedimento a Am, para a resolver esse problema, ele apresentou uma solução que destacamos no trecho a seguir.

Segundo ele, era necessário apenas mais uma moedinha de um centavo, mas elas haviam acabado, pois tinham sido usadas nas representações dos valores anteriores. A pesquisadora perguntou a Am se não teria um forma diferente de obter mais moedas de um centavo, mesmo que tivessem acabado na caixa reserva. Mas ele disse que achava que não. Assim, a pesquisadora pediu a ele que observasse as outras representações que já haviam feito e o resultado foi o seguinte:

P - Não teria como você fazer algo? E tirar moedas daí?

Am - Huuum. Não sei.

P - Porque olha só. Você tá colocando. Ó. Você aqui colocou 9 moedas de 1 centavo para representar o 9. E aqui você tá colocando o 5 e mais algumas moedas de 1.

Am - Ah, tá. Eu posso também fazer assim. 10, 20, 30, 40, 50, 60, 70, 80, 85...não. não vai dar.\{tenta encontrar uma solução para a falta de moedas de 1 centavo analisando as moedas que usou para formar o valor de 1,89$\}$

P - Aqui não dá. Mas será que aqui não dá, no leite condensado? Pra você poder usar alguma moedinha de um centavo daí?

Am - Eu não sei.

$\mathrm{P}-\mathrm{Não}$ ?

Am - Hum, hum.

$\mathrm{P}-\mathrm{Eu}$, sabe como eu faria? Pegaria essas moedas de 1 centavos que você colocou aqui.

Am - ESPERA!

$\mathrm{P}-\mathrm{H} \tilde{A}$ ?

Am - 1,2,3,4,5. Peguei cinco centavos.

$\mathrm{P}-\mathrm{Hã}$ ?

Am - Então dá pra eu por cinco centavos.

$\mathrm{P}$ - Aaaah. Então você tirou 5 moedinhas de 1 centavo daqui

Am - Pus uma moedinha de 5 centavos

$\mathrm{P}$ - No lugar né? É legal, era isso que eu ia fazer.

Com esse trecho, pode-se ver o desenvolvimento de Am quanto à formação dos números. Ele compreendeu que poderia recorrer a outras possibilidades, como, por exemplo, a troca de moedas de 5 centavos por 5 de 1 centavo, para obter as moedas que precisava. Com isso, evidenciamos, nesta sessão, que Am desenvolveu a compreensão do 
uso e a importância dos centavos na formação dos números, além da necessidade de recorrer a procedimentos pessoais de cálculos para conseguir adequar os meios para a resolução de problemas. Podemos dizer, ainda, que a mediação da pesquisadora foi importante no sentido de conduzir, por meio de sugestões e não de regras, a ação de Am.

\subsubsection{Décima segunda sessão de intervenção psicopedagógica.}

Data: 13-08-2015 Duração:40 min e 56 segundos

Esta sessão teve como objetivo retomar os passos da resolução do algoritmo da sessão anterior, focando na representação e no registro de números. Para o desenvolvimento das atividades, foram utilizamos como materiais: o dinheiro de brinquedo para representação das quantidades, papel e canetas coloridas para o registro dessas quantidades.

2.4.2.12.1 Desenvolvimento, resultados e discussão da décima segunda sessão.

O foco desta sessão foi retomar as atividades desenvolvidas somente pela pesquisadora e por Am na décima primeira sessão, na qual Af não estava presente. Portanto, realizamos a mesma atividade de representar as quantidades dos números constituintes do algoritmo $2,89+3,59+1,99+2,99=11,36$, referente à soma dos valores dos ingredientes para o preparo de uma receita de brigadeiro. Insistimos nessa atividade, por acreditar que poderia ajudar Af a realizar várias construções conceituais e pela dificuldade apresentada na décima sessão, quando representou o valor $\mathrm{R} \$ 11,36$ com duas partes inteiras. 
A pesquisadora iniciou a sessão relatando para Af, com a ajuda de Am, a atividade desenvolvida na décima primeira sessão. Desse modo, a pesquisadora propôs a Am e Af que realizassem essa mesma atividade. Af e Am aceitaram a proposta e procederam, portanto, a organizar sobre pedaços de papel a representação de cada um dos valores do algoritmo já referido. O procedimento utilizado por ambos foi o mesmo desenvolvido por Am na décima primeira sessão. Eles partiram primeiro buscando os valores inteiros, passando em seguida para a representação dos centavos.

Observamos, nesta sessão, algumas questões importantes a serem salientadas tanto por parte dos participantes, como por parte da pesquisadora. A primeira delas se refere à dificuldade expressa por Af de verbalizar o seu pensamento. Em sessões anteriores, esse dado já havia aparecido, mas somente nesta resolvemos considerá-lo na discussão, pela forma enfática com a qual Af se referiu. Por várias vezes a pesquisadora solicitou a Af que explicasse o seu procedimento, mas ela dizia não saber resolver as atividades e explicar ao mesmo tempo. Esse dado nos sugere que a verbalização, durante as aulas de Matemática, talvez ainda seja desvalorizada pelos docentes.

Outro ponto percebido, nesta sessão, refere-se à dificuldade de Af em diferenciar os valores absolutos dos relativos. Assim, como Am na décima primeira sessão, Af também expressou que no número 2,89 o dois era o algarismo de maior valor por ser real e não centavo e que no número 89 , o oito era menor que o nove. Isso mostrou uma necessidade maior de se trabalhar esses conceitos na escola, mas não focando na indicação de qual é o valor absoluto ou o relativo, mas na compreensão de como um valor absoluto se modifica quando nos referimos ao seu valor relativo.

Uma importante competência, envolvida no processo de compreensão da conceituação de valores relativos e valores absolutos, começou a se desenvolver por Af nesta sessão. Essa competência refere-se ao uso do numeral zero, na formação dos 
números. No trecho a seguir, notamos que Af elabora, mesmo que de modo incipiente, uma conceituação para o uso e a função do zero.

Af $-\mathrm{O}$ oito, ele é 80 . No caso que se botasse o zero no 9 o nove seria maior.

$\mathrm{P}-$ Ele ia ser quanto?

Af -90 .

$\mathrm{P}$ - Isso.

Af - Por isso que o 80 é maior, porque tem zero.

$\mathrm{P}$ - Mas ele é maior só porque tem o zero?

Af - Sim.

P - Quantas unidades têm no 80, gente?

Am -18 .

Af -18 , tem o $8,8 x \ldots$

$\mathrm{P}$ - Não, no 80 ?

Af - Peraí deixa eu fazer a conta aqui.

$\mathrm{P}$ - Só 8 Unidades?

Af - NÃO! Deixa eu fazer a conta.

Observamos, neste trecho, que a compreensão da lógica do uso do zero na formação desses números e também a compreensão da formação das quantidades presentes nas casas decimais (unidades, dezenas, centenas etc.) ainda não estava completa, haja vista que ambos, Am e Af, não sabiam informar a quantidade de unidades presentes no número 80. Contudo, podemos ver a autonomia dos dois e o engajamento na investigação na resolução das atividades. Diferentemente do início das sessões de intervenção, quando ao desconhecerem uma informação limitavam-se a dizer que não sabiam, neste exemplo, ficou muito evidente que o não saber inquietava Af e Am e, por isso, se autoquestionavam sobre suas próprias respostas e até mesmo queriam encontrar um modo de chegar até essa resposta.

Salientamos que a riqueza desse trecho se deve, ainda, à intensidade de esferas dos atos da fala presente nas interlocuções do extrato da transcrição. Na primeira fala aparece a esfera da informação, na qual estão descritos os atos de informar e exemplificar. Já quando Am diz que 80 possui 18 unidades e em seguida Af diz que é 18, mas tenta justificar, 
vemos duas esferas aparecerem. A da interação, identificada pelo ato de complementar, e a esfera da avaliação, descrita pelos atos de justificar e validar.

Evidenciamos que a mediação da pesquisadora teve uma importante contribuição para as elaborações de Af e Am. Contudo, salientamos que, como afirmado na análise de sessões anteriores, a modificação do modelo de mediação escolar foi necessária para que a pesquisadora pudesse mediar as sessões. Sendo assim, mesmo apresentando mudanças efetivas nesse modelo, a partir da quinta sessão, ainda observamos dificuldades por parte da pesquisadora. Isso comprova o que afirmam os autores quando se referem ao desenvolvimento de uma expertise, que leva tempo para se consolidar.

Para ilustrar essa nossa análise, retomamos aqui dois trechos da transcrição desta sessão. No primeiro, a pesquisadora não permite a contribuição de Am a Af. Já no segundo, incita essa participação. Isso confirma aquilo que assevera Fávero (2014) a respeito de Vergnaud (2009a): para que haja o desenvolvimento de competências, passamos por momentos de hesitações até chegarmos ao equilíbrio. Ou seja, a pesquisadora também estava em um momento entre a consolidação de um novo modo de mediação e um antigo modelo.

Trecho 1

$\mathrm{P}$ - Mostra pra mim onde você tem 9 e onde você tem o 8 .

Am - Huuuum.

$\mathrm{P}-$ Aqui você tem quanto? \{ silêncio $\}$

Am - Posso falar?

$\mathrm{P}$ - Deixa só ela terminar de contar que você fala.

Am - Só aqui é?

$\mathrm{P}-$ É... calma. Deixa ela fazer. \{Silêncio\}

$\mathrm{P}$ - Você que já terminou, quer fazer o próximo?

Am - Quero, quero!

Trecho 2

$\mathrm{P}$ - Olha só Am. Olha o que ela fez aqui. Ela não pegou notas como você. O que você quis representar aqui?

Af - Três reais. 
$\mathrm{P}-\mathrm{E}$ esses três reais aqui, é igual ao dele? \{Af acena que sim com a cabeça

$\mathrm{P}-$ É igualzinho, né? Mas não tem nenhuma diferença para o seu, Am?

Am - Deixa eu ver... eu não usei moedas, eu usei cédulas.

Finalizamos esta sessão apontando as competências demonstradas por Af e Am: a capacidade de buscar novas formas para chegar a resposta desejada, o desenvolvimento dos conceitos de números relativos, noção de casas decimais e uso do numeral zero. Quanto à mediação da pesquisadora, fica a consideração que uma alternativa de procedimento adotado na sessão, em vez de cada participante representar os números do algoritmo $2,89+3,59+2,99+1,99=11,36$, poderia ter sido a pesquisadora pedir para que os dois participantes representassem juntos os valores. Desse modo, incentivaria ambos a trabalhar em colaboração e a pesquisadora não teria cometido o equívoco de impedir, como fez no trecho1, sinalizado no parágrafo anterior, que Am interferisse na ação de Af.

\subsubsection{Décima terceira sessão de intervenção psicopedagógica}

Data: 15-07-15 Duração: 34 minutos

O objetivo desta sessão foi realizar cálculos com números decimais, utilizando materiais concretos. Em seguida, proceder aos registros dos valores representados com material concreto.

\subsection{Desenvolvimento, resultados e discussão da décima terceira sessão}

A sessão teve início com a conclusão da atividade realizada na semana anterior. Devido às questões que surgiram ao longo da décima segunda sessão, não conseguimos concluir a representação de dois valores, dos quatro valores dos ingredientes da receita de brigadeiros e, por esse motivo, tivemos de concluir essas representações nesta sessão. A 
pesquisadora preparou o ambiente, de modo que as representações dos valores feitas na semana anterior $(2,89$ e 3,59) estivessem sobre a mesa de Af e Am. Sendo assim, quando Af e Am terminaram de representar os valores que estavam faltando $(2,99$ e 1,59), ela apresentou a situação-problema da sessão: "Vamos juntar os valores representados de todos os ingredientes e vamos descobrir o total, ou seja, o valor que custariam os ingredientes da receita".

Af e Am questionaram se poderiam fazer somente o registro do algoritmo. A pesquisadora explicou que não, pois deviam manipular as moedas para encontrar a resposta e que somente depois realizariam o algoritmo. Af questionou a proposta da pesquisadora, dizendo que se fizessem com o material concreto, eles já saberiam a resposta que deveriam registrar no algoritmo. A pesquisadora explicou, no entanto, que não tinha problema fazerem daquela forma. É importante salientar que a intenção da pesquisadora, com essa proposta, não era simplesmente que Af e Am resolvessem uma "continha" para chegar à resposta correta do algoritmo, como se faz corriqueiramente nas salas de aula. O foco era o processo de resolução do algoritmo e as possibilidades de autorregulação e de tomadas de consciência que esse processo de resolução poderia oportunizar a esses indivíduos.

A pesquisadora sugeriu aos participantes que discutissem entre si para encontrar um procedimento adequado para a resolução dessa situação-problema. A primeira ideia que surgiu foi proposta por Af e consistiu em somar os valores na ordem que estão registrados no algoritmo. O que seria então: $2,89+3,59+2,99+1,89$. Essa proposta foi recusada por Am, que afirmou ser difícil calcular, daquele modo, com as moedas. Segundo ele, resolver somente com o algoritmo seria mais fácil. A pesquisadora, portanto, com a intenção de encorajar os participantes a utilizar o dinheiro para resolver a questão, comparou essa conta a outra qualquer que fariam no supermercado e, por isso, deviam usar os materiais como 
recurso para o cálculo. Contudo, Am apresentou uma resposta surpreendente para a pesquisadora, como podemos ver no trecho a seguir.

P - No dia a dia, se vocês têm esses quatro valores, como vocês vão somar? Pra pagar no mercado?

Af-É.

$\mathrm{P}-\mathrm{E}$, Af, vocês estão só falando é. Mas e aí? Façam.

Am - Ah, eu dou uma nota de 20 e vem o troco. É mais fácil.

A resposta de Am indica uma certa passividade e sugere que o menino talvez utilizasse essa representação (dinheiro) com pouca frequência no seu dia a dia. Essa resposta de Am mostrou a pertinência do uso de várias formas de representação para a realização das operações matemáticas. A pesquisadora insistiu que utilizassem as moedas e cédulas que estavam sobre a mesa de Am e Af. Então, logo em seguida, Af propôs um segundo procedimento para resolver o problema: somar primeiro as cédulas e em seguida as moedas. Em outras palavras, somar primeiro a parte inteira e depois somar a parte decimal.

Com isso, em primeiro lugar, somaram as cédulas e apontaram como resultado sete reais. A pesquisadora solicitou aos participantes que registrassem esse valor no papel e surgiu, assim, uma discussão entre a forma como Af representou sete reais e a forma convencional de representar esse valor. No entanto, essa discussão não foi levada em consideração por Af, que simplesmente disse que aquele era o seu jeito de fazer o sete. $\mathrm{O}$ que indicou que Af precisava conhecer novas formas de representar um mesmo número.

Em seguida, iniciaram a parte da soma apenas das moedas. Apesar de terem sido orientados a fazerem a adição das moedas juntos, decidiram, cada um, somar dois valores. Assim, Am somou 89+59 e Af 99+99. A soma de Am resultou no número 1,48. Primeiro ele juntou duas moedas de 50 e indicou ter 1 real. Em seguida, partiu do um real e começou a contar as moedas de 10 centavos, depois as de 5 centavos e por último as de 1 
centavos. O procedimento de Af demonstrou semelhanças quanto ao procedimento de Am. Primeiramente foi incorporando à sua contagem as moedas que ela foi encontrando, começando primeiro pelas moedas de 50 , depois moedas de 10 e 5 ao mesmo tempo, juntando as de 1 centavo apenas no final.

Quando Af e Am encontraram os resultados de suas adições, a pesquisadora questionou como iam fazer para juntar os dois resultados para chegar à resposta que desejavam sobre o número de unidades da parte decimal dos valores dos preços dos ingredientes. Af propôs trocar as moedas por cédulas. Em outras palavras, foi agrupando valores, de modo que pudessem diminuir o volume de moedas com as quais estavam operando. No trecho a seguir vemos a discussão entre Af e Am. Observem que quando Am se refere a dinheiro, estava fazendo menção a cédulas.

Af - 2,98. Pra gente não ficar com tantas moedas assim, a gente troca assim. Am - AH, A GENTE TROCA AS MOEDAS POR DINHEIRO!

Neste trecho, temos duas esferas dos atos da fala que foram pouco utilizados por Am e Af ao longo das sessões. A primeira é a esfera acional, apresentada pelo ato de propor. Já a segunda esfera é a da interação, representa pelo ato de completar, realizado por Am. Isso indicou que tanto Af como Am estavam sendo mais participativos nas sessões e proposições que lhes eram feitas. Além disso, podemos ver que estavam, cada vez mais, à vontade para propor alternativas para solucionar as suas dúvidas. Af, observando a caixa reserva de cédulas que estava sobre a mesa, propôs agrupar as moedas em grupos que representassem valores maiores. Ou seja, estava operando, utilizando a lógica do agrupamento.

Sendo assim, agruparam duas moedinhas de 50 com 4 de 25 e formaram dois reais. Após esse procedimento, pegaram uma cédula de dois reais da caixa reserva e depositam, nessa mesma caixa reserva, as moedas que somadas davam 2 reais. Separaram os 98 
centavos restantes dos 2,98; e desses 98, Af contou 5 moedas de 10 e formou 50 centavos. Em seguida solicitou a Am e a pesquisadora que lhe dessem uma moeda de 50 inteira. Quando Af se propôs a formar mais um grupo para trocar por outras moedas da reserva, descobriu que só tinha 48 centavos. Nessa hora, a pesquisadora sugeriu que Af utilizasse moedas do montante que estava em poder de Am e foi isso que ela fez. Esse procedimento é retomado aqui, mas já havia sido realizado em sessões anteriores.

Af continuou operando e buscou mais duas moedas de 2 centavos, totalizando 50 . Mais uma vez, depositou as moedas, que juntas totalizavam 50, na caixa reserva e recebeu uma moeda de 50 centavos. Af se viu com duas moedas de 50 centavos e imediatamente pediu a pesquisadora que retirasse 1 moeda de 1 real da reserva para dar a ela e entregou as duas moedas de 50 para serem colocadas na caixa a reserva. Na sequência, agrupou mais uma vez moedas de 10, 5 e 1 centavo e formou 50 centavos. Em seguida, juntou moedas que davam 25 centavos por uma única moeda de 25 centavos.

Após estas trocas todas, começam a contar qual o valor em dinheiro tinham no total. Então somaram os sete reais de cédulas que tinham incialmente, aos $\mathrm{R} \$ 2,00$ de cédulas que adquiriram com o agrupamento das moedas. E chegaram ao total de nove reais em cédulas. Em seguida, começam a contar apenas as moedas que ficaram sobrando e chegaram ao total de $\mathrm{R} \$ 1,96$ centavos. Nesse momento Af proferiu que o total era de $\mathrm{R} \$ 10,96$; mas a pesquisadora questionou esse resultado. $\mathrm{E}$ para descobrir então se a organização de Af e Am estava correta, ela propôs que resolvessem o algoritmo no papel. E a pesquisadora antecipou que a possível divergência entre o valor resultante do cálculo com as moedas e o cálculo realizado com o algoritmo se justificaria por algum descuido na hora do agrupamento das moedas, realizado por Af e Am. Após ambos resolveram o algoritmo e apontaram que o resultado era de 11,36. 
Apesar de o cálculo não ter coincidido com o valor correto esperado para o algoritmo dessa adição, a sessão se mostrou riquíssima em termos de competências desenvolvidas por Am e Af. Eles demonstraram ter desenvolvido o procedimento da formação de agrupamentos e a autonomia para a criação de formas alternativas para a resolução de cálculos matemáticos.

\subsubsection{Décima quarta sessão de intervenção psicopedagógica}

Data: 10/09/2015 Duração: 58 minutos

O objetivo desta sessão foi manipular e operar com valores decimais. Realizar a comparação entre a representação e o registro de valores de moedas. Somar moedas referentes a uma suposta venda de brigadeiros.

\subsection{Desenvolvimento, resultados e discussão da décima quarta sessão}

Esta sessão se desenvolveu em torno da pesquisa do valor arrecadado em uma suposta venda de brigadeiros realizada pela pesquisadora e que se encontrava guardada em uma caixa. Optamos pela utilização de moedas de real, verdadeiras, diferentemente do que vinha sendo realizado nas sessões anteriores, nas quais fizemos uso de dinheiro de brinquedo. Esta nossa opção de utilizar moedas verdadeiras permitiu que a situaçãoproblema tivesse uma maior relação com a realidade evocada pela situação-problema.

Decidimos, também, não fazer uso de cédulas de modo que os sujeitos tivessem que manipular valores não inteiros, haja vista que, nas sessões anteriores, eles esquivavam-se do uso desses valores. Utilizamos, ainda, uma tabela impressa em uma folha de papel, na qual foram registradas cada uma das moedas existentes na caixa. A situação possibilitou 
discussões a respeito do registro dos valores do Sistema Monetário Nacional, ao uso e função do numeral zero na formação e significado dos números e sobre a multiplicação de números decimais.

Esta sessão, teve início com a investigação da data e da hora, assim como todas as outras sessões. Esse momento, no entanto, teve uma duração pequena, devido ao tempo de resposta dos participantes Af e Am às perguntas que lhe foram dirigidas pela pesquisadora. Imediatamente após a indagação da pesquisadora, eles disseram que estavam no dia 10 de setembro de 2015, às 09h17min. Ao comparar a atitude dos participantes nesta sessão com suas atitudes nas sessões anteriores, em que eles ficavam discutindo para chegar a um acordo sobre a hora, vemos que nesta sessão apenas informaram as horas de forma precisa. Esse fato mostra que já estavam mais familiarizados com as representações do sistema de medida de tempo.

Na sequência desse fato, foi apresentada pela pesquisadora a Am e Af uma caixa decorada. A pesquisadora não contou de imediato qual era o seu conteúdo, o que despertou em Af e Am especulações a esse respeito. Quando ela disse que dentro da caixa encontrava-se o resultado de uma venda de brigadeiros, Af sugeriu que pudesse ser dinheiro o que havia dentro da caixa. Diante da sugestão de Af, a pesquisadora abriu a caixa revelando, que, de fato, havia dinheiro dentro dela. A pesquisadora, então, explicou aos participantes que não sabia qual que era o valor ganho naquela venda e que necessitava da ajuda deles para realizar a contagem.

De imediato, Am disse que sabia o quanto havia na caixa. Quando perguntado pela pesquisadora qual seria esse valor, o menino respondeu com uma nova pergunta: "Assim, de cor?" A pesquisadora disse que sim, e Am respondeu que dessa forma não sabia, mas apresentou uma hipótese para a quantidade dentro da caixa: "mas aqui, só pelas moedas de um real, tem muito". Essa fala de Am indicou que ele estava fazendo uso do componente 
do sentido de número: reconhecimento dos efeitos relativos de operações com número. Assim, apesar de não ter contado ainda, ele estimou pela quantidade de moedas de um real, presentes na caixa, que provavelmente o valor não era pouco.

Podemos dizer, nesse caso, que Am tomou consciência que o resultado de um determinado cálculo é influenciado tanto pelo valor dos números a serem calculados como pelo número de vezes que esses números se repetem. Sendo assim, como havia várias moedas de um real, que é a moeda de maior valor, provavelmente o montante na caixa não era pequeno. Ainda em referência a esse extrato, podemos dizer que essa proposição de Am revela a presença da esfera da avaliação, na qual podemos identificar os atos de justificar e validar.

Diante disso, a pesquisadora apresentou a situação-problema da sessão, que consistia em contar todas as moedas da caixa e, por meio de um procedimento próprio, calcular o total resultante da venda dos brigadeiros. Sendo assim, ela convidou Af e Am a elaborarem um procedimento para a contagem das moedas da caixa. Eles aderiram à proposta prontamente, e sugeriram separar as moedas em grupos, considerando os seus valores. Formaram, então, grupos das moedas de $\mathrm{R} \$ 0,05 ; \mathrm{R} \$ 0,10 ; \mathrm{R} \$ 0,25 ; \mathrm{R} \$ 0,50 ; \mathrm{R} \$$ 1,00 .

Após a separação das moedas nos grupos, de acordo os valores de cada uma, a pesquisadora explicou o procedimento que deveriam realizar durante a contagem das moedas. Com isso, apresentou uma tabela composta por oito colunas e quatro linhas. Nessa tabela, deveriam ser registrados os valores de cada moeda representada e o número de moedas encontradas para cada um dos valores, o total em dinheiro, após o somatório das moedas e, por fim, o número total de moedas e o valor total do montante de moedas. 


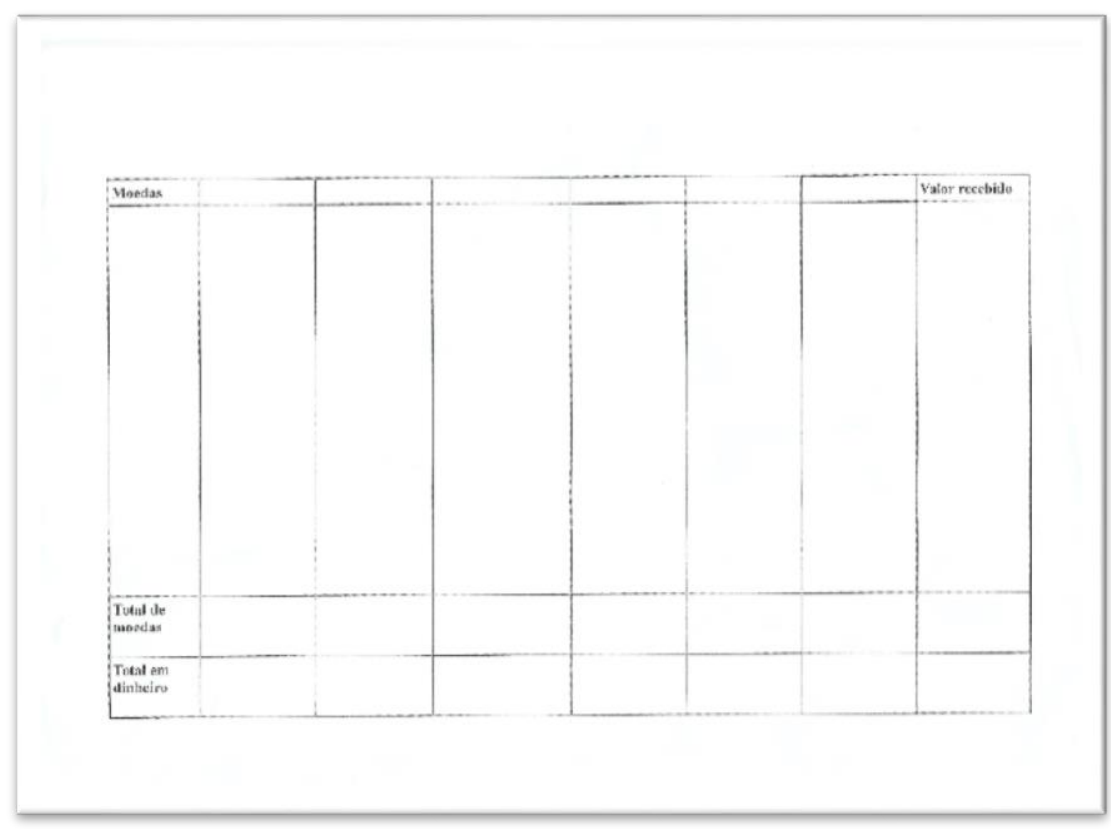

Figura 15. Tabela utilizada para o registro dos valores.

A pesquisadora convidou os participantes a começarem a organizar os registros na tabela. Ao perguntar qual seria o primeiro valor a registrar, Af disse que era a moeda de cinco centavos. A pesquisadora, no entanto, argumentou com Af que antes dessa moeda existia uma de menor valor. Mas Af informou que essa moeda à qual a pesquisadora se referia, não existia mais, que era a moeda de $\mathrm{R} \$ 0,01$. A pesquisadora insistiu no registro do valor $\mathrm{R} \$ 0,01$, na tabela, devido à natureza da atividade que visava que os participantes visualizassem todas as moedas que existem em nosso sistema monetário.

Após registrarem o valor de um centavo, registraram também, o valor de $R \$ 0,05$; $\mathrm{R} \$ 0,10 ; \mathrm{R} \$ 0,25 ; \mathrm{R} \$ 0,50 ; \mathrm{R} \$ 1,00$. Ao final desses registros, procederam ao registro de cada uma das moedas dos agrupamentos, na folha fornecida pela pesquisadora. A cada moeda que era contada, ao mesmo tempo, era feito o seu registro no papel. Enquanto um dos participantes contava, o outro registrava. De modo que, ao final das moedas de 0,05, aquele que estava registrando passava a contar as moedas de $\mathrm{R} \$ 0,10$. Procederam assim, até completar a tabela. 


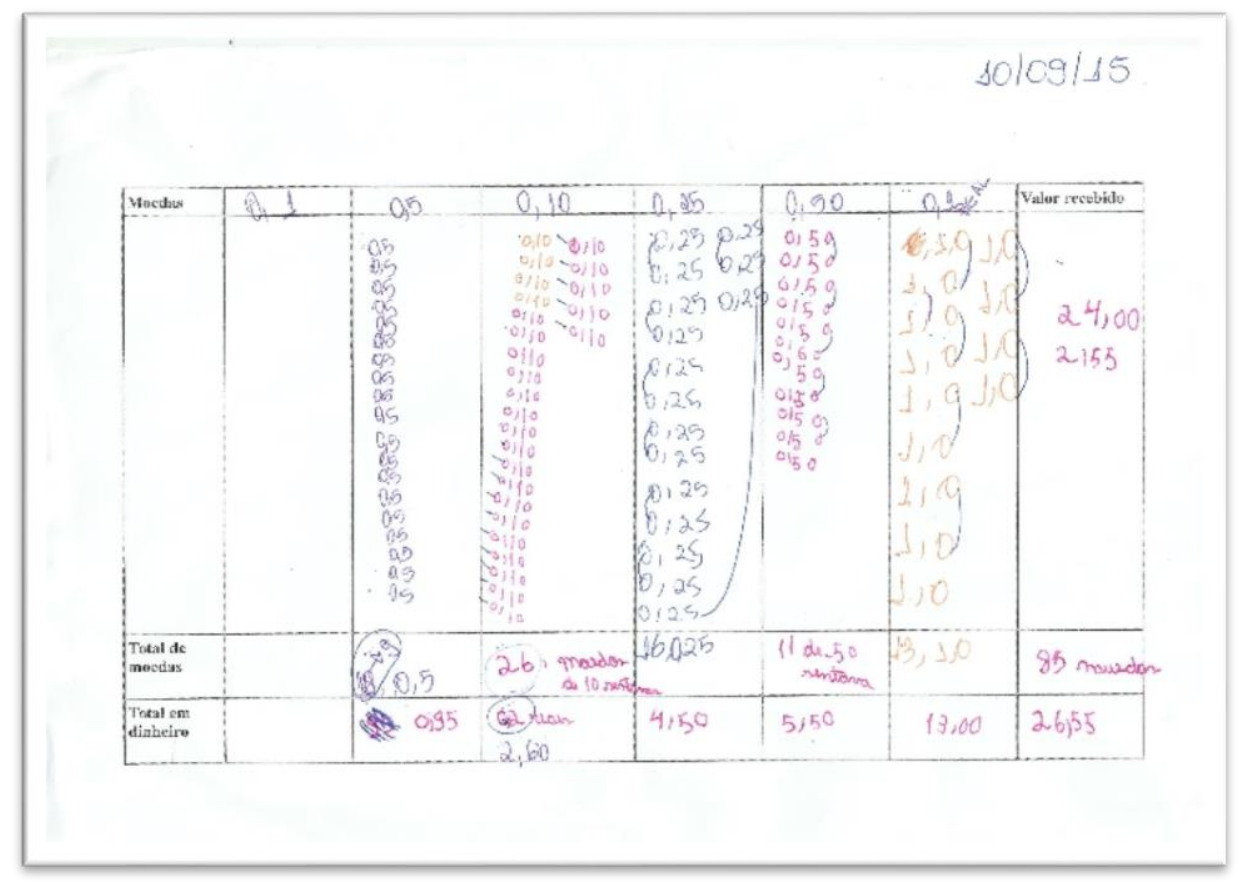

Figura 16. Tabela com os registros dos valores das moedas.

Durante o registro dos valores das moedas na tabela, foi possível discutir, com os participantes, dois conceitos matemáticos fundamentais para a compreensão da lógica do Sistema de Numeração Decimal. O primeiro deles referia-se ao uso da vírgula nos números decimais. Logo nos primeiros registros, a pesquisadora questionou se não estava faltando algo nos registros dos valores das moedas e Am apontou que era a vírgula. O segundo desses conceitos discutidos foi o uso do zero, que foi mencionado tanto por Af, como por Am, como sendo o responsável pela modificação dos valores dos números. No trecho a seguir, Am faz menção tanto ao uso zero como ao uso da vírgula.

$\mathrm{P}$ - Isso. E os cinco centavos? Como fica?

Am - Se pôr o zero aqui, fica cinquenta.

$\mathrm{P}$ - Do lado de lá, né?

Am - É. Tem que pôr desse lado aqui.

$\mathrm{P}-\mathrm{E}$ antes ou depois?

Am - ANTES!

No trecho que destacamos, vemos que Am afirma que dependendo do local onde se localiza o zero no número, há uma alteração do valor desse número. Quando tanto Am 
como a pesquisadora se referem, no trecho, aos lados dos números, estão se referindo à parte inteiro e à parte decimal desse número.

Após o registro de todos os valores na tabela, Am e Af realizaram a contagem das moedas para identificar o valor que estava contido na caixa. Eles utilizaram como procedimento para a contagem dos registros das moedas de $\mathrm{R} \$ 0,05$ e $\mathrm{R} \$ 0,10$ a contagem um a um. Com esse procedimento, apontaram que tinham 19 moedas de $\mathrm{R} \$ 0,05$, que totalizaram $\mathrm{R} \$ 0,95$, e 26 moedas de $\mathrm{R} \$ 0,10$, totalizando $\mathrm{R} \$ 2,60$.

Quando foram somar as moedas de $\mathrm{R} \$ 0,25, \mathrm{R} \$ 0,50$ e as de $\mathrm{R} \$ 1,00$, o procedimento foi alterado. Fizeram marcas de duas em duas moedas e em vez de contar o valor de cada uma delas contaram o resultado da soma de duas moedas. Ou seja: nas colunas das moedas de $\mathrm{R} \$ 0,25$ contaram quantas duplas de $\mathrm{R} \$ 0,50$ tinham. Na coluna das moedas de $\mathrm{R} \$ 0,50$ somaram as duplas de $R \$ 1,00$ e na coluna das moedas de $R \$ 1,00$ contaram as duplas que resultavam em $R \$ 2,00$. Com isso chegaram ao total de 16 moedas de $R \$ 0,25$, totalizando $\mathrm{R} \$ 4,50 ; 11$ moedas de $\mathrm{R} \$ 0,50$, totalizando $\mathrm{R} \$ 5,50$; e 13 moedas de $\mathrm{R} \$ 1$ real, totalizando $\mathrm{R} \$ 13,00$ reais.

Para calcular o total das moedas, repetiram os procedimentos realizados nas décima segunda e na décima terceira sessões. Primeiro somaram as moedas de maior valor, depois as de menor valor. Ao final desses cálculos, descobriram que tinham na caixa 85 moedas no total e $\mathrm{R} \$ 26,55$ em dinheiro.

Esta sessão evidenciou que Af e Am se desenvolveram quanto às operações do SND e quanto a sua lógica. Demonstraram saber operar com agrupamentos, somar com números decimais, diferenciar em um número decimal a parte inteira dos decimais, realizar contagem um a um. Demonstraram ainda a compreensão quanto ao uso e a função do numeral zero e da vírgula. 


\subsubsection{Entrevista final}

As entrevistas, descritas neste item, foram realizadas uma semana após a última sessão de intervenção. Elas tiveram como objetivo evidenciar as percepções dos participantes quanto ao processo de intervenção do qual participaram. As entrevistas se desenvolveram em torno de três eixos: aprendizagens adquiridas ao longo do quinto ano, aprendizagens adquiridas ao longo das sessões de intervenção e análise do caderno.

\subsection{Participante Af}

A entrevista com Af teve a duração de 32 minutos e 36 segundos. A pesquisadora iniciou a conversa perguntando a Af sobre as aprendizagens dela no quinto ano. A menina fez referência aos conteúdos de fração e multiplicação. Disse que havia aprendido um pouco de fração, mas que sabia bem mais sobre multiplicação, e que tinha dificuldade na tabuada de multiplicação do numeral seis.

Foi perguntado a Af se ela havia aprendido alguma coisa durante o processo de intervenção e ela afirmou que estava se desenvolvendo bem. Segundo ela, antes das sessões não prestava atenção nas aulas da professora, mas com as sessões estava mais atenta ao que era mediado em sala de aula. Af concluiu dizendo que percebeu que os conteúdos de Matemática não eram tão complexos como ela achava antes. Com isso, evidenciamos que o processo de intervenção permitiu que Af reelaborasse conceitos que antes não eram compreensíveis para ela, o que a auxiliou no entendimento de outros conceitos mediados pela sua docente.

Ao analisamos o caderno de Matemática de Af, conversamos sobre o que era uma fração, conteúdo que ela estava estudando em sala, com a professora. Entretanto, esse foi um conteúdo do qual Af disse que não sabia explicar o seu significado. Sua referência à 
fração foi apenas a respeito do seu registro (numerador sobre denominador) e não como se formavam as frações ou mesmo qual a sua função.

No caderno havia um problema que não estava respondido, e a pesquisadora o escolheu para conversarem a seu respeito. A primeira pergunta foi por que não havia feito aquela tarefa. Af disse que não sabia resolvê-la porque era difícil. A pesquisadora convidou Af, então, a responder juntamente com ela, o que foi aceito pela participante. A situação era a seguinte: Richard comprou na granja nove caixas de ovos com 17 dúzias de ovos em cada caixa, para levar para vender no supermercado. Quantos ovos foram comprados?

A pesquisadora perguntou qual era a primeira coisa a se fazer quando se tinha a intenção de resolver um problema como aquele. Af imediatamente disse que tinha que descobrir "quanto" e "qual o sinal". Ela convidou, portanto, Af a tentar, a partir da leitura do problema, identificar elementos que pudessem fundamentar a resolução. Assim, a pesquisadora foi fazendo perguntas a Af de modo que ela pudesse entender o contexto da questão. Ela pediu a Af que fosse registrando as respostas para essas questões, em um papel. Algumas das perguntas foram: o que o Richard comprou? Mas quantos ovos ele comprou? Você sabe o que é uma dúzia?

Af informou que a dúzia era doze e, partir disso, iniciaram a resolução do problema. Primeiramente Af escreveu 12 dezessete vezes. Com isso, realizou uma soma que resultou no número 204 (número das 17 dúzias do problema). Seguindo o mesmo raciocínio, Af somou o número 204, nove vezes chegando ao total de 1836 (nove caixas com 17 dúzias). Após essa resolução, a pesquisadora convidou Af a pensar que ela havia utilizado, para a resolução daquele problema, os mesmos procedimentos que foram usados durante a intervenção. Af concordou com a pesquisadora enquanto olhava para as suas 
contas no papel. Esse dado revelou que a resolução passo a passo permitiu que um problema que parecia bastante complexo passasse a ser possível de ser resolvido.

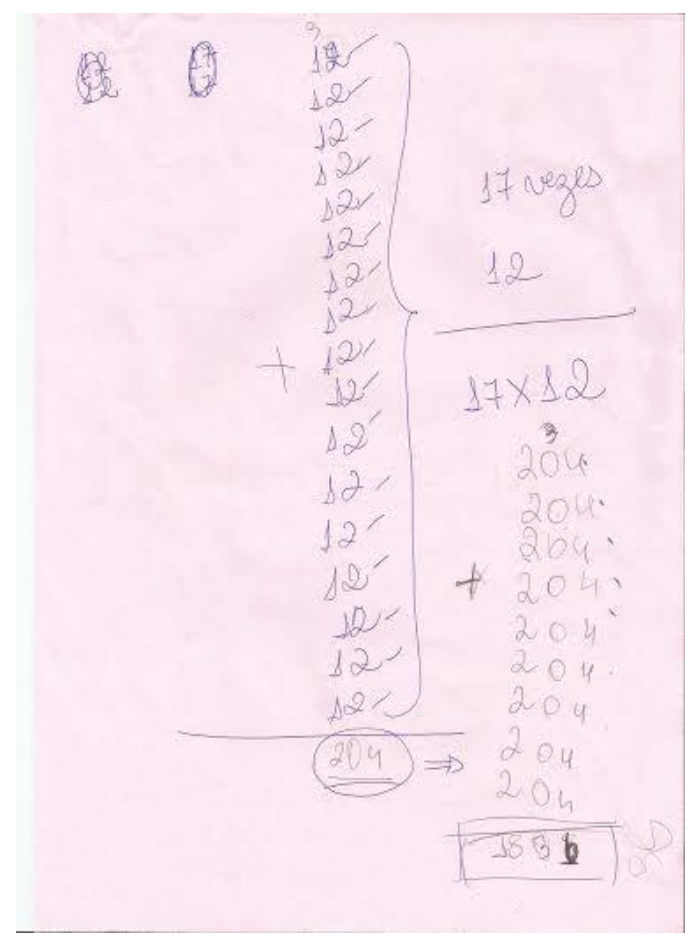

Figura 17. Registros de Af, para a resolução da situação-problema

Ao término da resolução e da entrevista, a pesquisadora perguntou se Af achava que teria aprendido algo durante a intervenção. Af disse que tinha aprendido muito, principalmente divisão, multiplicação e subtração. Disse ainda que, do conjunto das sessões, aquela que mais havia gostado foram as sessões nas quais fizeram uso do dinheiro e que, em segundo lugar, a sua preferência era pelas sessões nas quais foram utilizadas as forminhas de brigadeiro.

\subsection{Participante Am}

A entrevista final com Am teve duração de 32 minutos e 10 segundos. A pesquisadora iniciou a entrevista perguntando o que ele estava aprendendo na escola naquele ano ( $5^{\circ}$ ano). Am disse que estava aprendendo muitas coisas, mas explicitamente 
fez menção apenas à operação de multiplicação. Ao folhear seu caderno de Matemática, ela lhe perguntou o que seriam aqueles números uns sobre os outros, que estavam registrados. A pesquisadora estava se referindo aos registros de fração no caderno de Am, mas ele disse que não lembrava o nome.

A pesquisadora observou, também, que havia vários exercícios no caderno de Am que eram sobre fração, números mistos e mínimo múltiplo comum (MMC). Ao ser convidado a explicar o que significava cada um daqueles exercícios, Am respondeu que não conseguiria explicá-los, uma vez que eram conteúdos novos, que estava começando a aprender. Vendo que não havia muitos exemplos de atividades do caderno de Am que pudessem motivar uma conversa, uma vez que seu caderno era novo e tinha pouca produção, a pesquisadora pediu a Am para falar sobre a multiplicação que, segundo ele, era um conteúdo que havia aprendido.

Sendo assim, Am registrou o algoritmo 2783 x 6 para mostrar o que sabia fazer. No procedimento desenvolvido, Am registrou no papel a tabuada do numeral seis com os seguintes fatos: $6 \times 2,6 \times 3,6 \times 4,6 \times 5,6 \times 6,6 \times 7,6 \times 8$. Colocou a resposta ao lado de todos, exceto de $6 \times 8$. Naquele momento, disse que não sabia resolver o algoritmo $2783 \times 6$ porque não sabia a resposta para 6x8. Quando $\mathrm{P}$ perguntou a Am o porquê dele saber o resultado de $6 \times 7$ e não saber $6 \times 8$, pediu para a pesquisadora esperar e se engajou na pesquisa de quanto dava o resultado de 6x8. Am iniciou, portanto, uma contagem partindo do número 42 (resultado de 6x7). Am adicionou mais 6 unidades ao 42 e apontou como resultado de 6 x 8 o número 48. Ao encontrar esse resultado, disse que seria possível resolver o algoritmo, e foi o que fez. Esse dado da entrevista mostrou o engajamento e autonomia de Am na busca do resultado de 6x8. Diferentemente do início das sessões, quando Am apenas dizia que não sabia e não se mobilizava para tentar resolver a questão. Isso nos indicou que Am 
havia se desenvolvido em relação à competência de investigar procedimentos possíveis para a resolução de problemas.

O algoritmo de 2783 x 6 resultou em 16.498. A pesquisadora, no entanto, não focou suas argumentações no resultado dessa questão, mas, sim, no numeral 2.783 (multiplicando) desse algoritmo. Ela perguntou qual dos algarismos desse número era o maior, e Am disse que era o 8. A pesquisadora, contudo, relembrou Am do que haviam desenvolvido nas sessões décima primeira e décima segunda, e ele afirmou, então, que o 8 era maior do que o 3 porque valia 80 . Am disse que não sabia quanto valia o algarismo 7 e a pesquisadora lhe disse que esse número valia 700. No entanto, ela não respondeu quanto valia o algarismo 2 e perguntou a Am. O menino disse primeiro que não sabia qual era o valor do 2, mas logo em seguida, disse que valia 2000. Ao final, Am apontou como o número de maior valor, naquele numeral, o algarismo 2, porque seu valor era 2000. Isso mostrou que, mesmo sem conceituar de forma explicita a lógica da relação entre números relativos e casas decimais, Am foi capaz de perceber que a cada nova casa decimal havia um acréscimo no valor das unidades.

Em seguida, a pesquisadora propôs retomar o resultado 16.498, do algoritmo 2783 x 6, feito por Am anteriormente. Am apontou, então, que os valores relativos dos algarismos do numeral 16.498. Disse que o valor relativo do 8 era 8 mesmo, do 9 era 90, do 4 era 400 e do 6 era 6 mil. Contudo não sabia dizer quanto valia o 1, dizendo que era difícil. Apesar dessa avaliação de Am quanto à dificuldade, disse que sabia que tinha algo aumentando no número, mas não sabia o que era. Ou seja, percebia o valor relativo tinha relação com a casa decimal que ele ocupava, mas ele sabia qual era a lógica subjacente. Ele deu algumas respostas para o valor desse número como, por exemplo: mil ou um milhão.

A pesquisadora, no entanto, disse que aqueles valores, por ele apontados, não correspondiam ao valor do numeral 1 em 16.498 e iniciou uma argumentação para que Am 
construísse a sua resposta para aquela pergunta. Primeiro ela decompôs o número 16, de 16.498, deixando claro para Am que aquele número era composto da seguinte forma: $10.000+6.000$. Am analisou por um tempo aquilo que ela lhe havia dito e, de repente, disse que aquele o 1 valia 10.000. Esse dado mostrou a importância da mediação da pesquisadora, que não deu respostas para Am, mas conduziu o seu pensamento, para que ele mesmo pudesse avaliar os elementos envolvidos na situação, chegando à resposta.

Para encerrar a entrevista, a pesquisadora perguntou o que Am havia aprendido durante as intervenções e ele disse que tinha aprendido Matemática e que tinha gostado de todas as sessões de intervenção, sem dar ênfase a nenhuma específica. Salientou que quanto ao material utilizado nas sessões, gostou do dinheiro, das forminhas de brigadeiros e dos palitos de picolé. A pesquisadora sabendo da resistência inicial de Am, durante as intervenções, a respeito do uso de materiais concretos como apoio às resoluções, perguntou se ele achava que fazer cálculos com palitos era bom ou ruim. Am respondeu que era bom, mas preferia utilizar moedas. Isso mostrou que Am passou a aceitar o uso do material concreto e a reconhecer a sua importância na estruturação do seu entendimento durante uma resolução.

Am disse, ainda, que os palitos o ajudaram nas operações de adição, e a pesquisadora lhe perguntou se usaria os palitos em sala de aula para resolver problemas, e ele disse que sim, mas que antes das sessões não usaria. Isso mostra que a intervenção reconstruiu uma concepção de Am quanto aos procedimentos para resolução da Matemática. Para finalizar, disse que as intervenções o ajudaram nas aulas de Matemática e também de português, sem dar detalhes. Ao final da conversa, quando a pesquisadora disse que as sessões terminariam ali, o menino começou a chorar dizendo que queria continuar. Isso nos sugere que, de fato, as intervenções foram importantes para Am e as suas aquisições escolares. 


\subsection{Discussão Geral das Sessões}

Neste item referente à discussão geral da intervenção, apresentamos alguns aspectos principais que evidenciamos ao longo das sessões de intervenção psicopedagógicas. Nessa discussão, buscamos recuperar aqueles aspectos particulares do conjunto das sessões que revelaram dados sobre: as competências e dificuldades numéricas dos participantes; o desenvolvimento de novas competências numéricas; as principais esferas dos atos da fala identificadas nas interlocuções das sessões; as regulações cognitivas e sociocognitivas, as tomadas de consciência dos participantes e a mediação desenvolvida pela pesquisadora durante as sessões.

Como já informado anteriormente, esta fase da pesquisa se desenvolveu em 14 sessões psicopedagógicas semanais. Doze dessas sessões foram realizadas com a presença dos dois participantes e duas com a presença de um ou do outro. Essas ausências, entretanto, não apresentaram prejuízos ao encadeamento das sessões ou às construções conceituais que Af e Am desenvolveram.

As 14 sessões foram desenvolvidas em torno de um eixo comum: o planejamento de uma microempresa de docinhos para festas. $\mathrm{O}$ desdobramento da proposta levou às situações-problemas que, para serem resolvidas, necessitaram - e esta era nossa intenção o uso da lógica do Sistema Numérico Decimal e das operações fundamentais.

Estabelecemos uma mesma rotina para as 14 sessões. Todas foram iniciadas com a exploração do calendário, os dias decorridos entre a sessão anterior e a seguinte, as semanas, as mudanças dos meses e assim por diante. Em seguida, também era explorado o relógio analógico: a hora de início e de término da sessão, a duração da sessão etc. Em seguida, eram retomadas as situações-problemas da sessão anterior e resolvidas as eventuais pendências. 
Desse modo, as sessões se centraram nas medidas de tempo (data e hora) e nos conceitos do Sistema de Numeração Decimal e suas operações, abrangendo a composição e decomposição de números, a identificação de valores absolutos e relativos, as estimativas numéricas e as quatro operações aritméticas. Também foram focados: o Sistema Monetário Nacional, abrangendo a atribuição de valor de produtos, a formação dos valores com as unidades do Real, e os números decimais: a adição de números decimais, a formação dos números decimais e o uso da vírgula.

O tema do planejamento de uma microempresa de docinhos para festas permitiu que Af e Am trouxessem exemplos de seus cotidianos para o contexto das sessões da pesquisa. Esses exemplos foram utilizados pela pesquisadora para a proposição de novas situações-problemas envolvendo as competências numéricas.

A análise da transcrição de cada uma das sessões, como já apresentado na sessão anterior, considerou, tal como propõe Fávero (2001, 2009b), a natureza das atividades propostas, a sequência de ações dos participantes durante essa atividade e a natureza da mediação, realizada pela pesquisadora durante tais sessões. Como defende a autora, isso nos facilitou identificar, no decorrer das sessões, as competências e as dificuldades dos participantes, assim como nos permitiu a análise crítica da natureza das intervenções da pesquisadora durante as sessões e o desenvolvimento das novas competências que essa mediação possibilitou.

É preciso ressaltar um dado relevante deste estudo no que se refere à interação entre desenvolvimento e escolarização, que requer ser considerado nos trabalhos futuros junto a professores que lidam com a sala de aula regular ou com a sala de recursos. Trata-se da tentativa dos participantes em indicar uma resposta imediata para uma dada situaçãoproblema, que se apresenta, na busca do algoritmo compatível, através de algum tipo de regra. Esta tendência já foi ressaltada inúmeras vezes (ver, por exemplo: Fávero, 2009b; 
Pina Neves, 2008) e se mostrou persistente durante as sessões de intervenção. Isto é: os participantes relutavam em utilizar materiais concretos ou notações não formalizadas como instrumentos para os cálculos que as resoluções das situações-problemas demandavam, persistindo na busca da aplicação de uma regra que desse a resposta certa.

Podemos dizer que, como analisado pelas autoras citadas e outros, essa relutância quanto ao uso de registros alternativos e de materiais concretos diversos e, ao mesmo tempo, essa procura por regras buscadas na memória se relacionam com o tipo de procedimento didático que é desenvolvido na sala de aula escolar. Esses aspectos estão diretamente relacionados ao desenvolvimento de competências numéricas e, portanto, relacionados ao binômio inclusão/exclusão (ver também Muniz, 2009). Consequentemente, os participantes apresentaram, nas primeiras sessões, dificuldades com as operações numéricas envolvidas na leitura das horas no relógio analógico e na relação entre a leitura do início da sessão e a sua releitura após os 40 minutos que foi o tempo médio, estipulado para as sessões.

No que se refere à utilização de cédulas e moedas de Real, por um lado, esse uso confirmou algumas dificuldades dos sujeitos quanto ao SND e com o próprio conceito de número, por outro lado, revelou estratégias interessantes do ponto de vista do conhecimento numérico. Am e Af, ao evitarem a lida com os centavos, ao mesmo tempo que demonstravam dificuldades com as partes decimais de um número não inteiro, mostravam a capacidade em lidar com estimativas e arredondamentos.

O processo de intervenção possibilitou aos participantes desenvolverem a compreensão do SND através dos significados do número, como proposto por Corona (2010), ao qual nos referimos na fundamentação teórica desta dissertação. Assim, o entendimento do significado de números e as operações pode ser identificado nas ações de Af e Am ao longo das sessões de intervenção (retomaremos alguns exemplos neste item). 
A importância da mediação da pesquisadora e a importância da situação interativa das sessões também ficaram evidentes no decorrer do estudo.

Logo nas primeiras sessões, foi evidenciada a capacidade de compor e decompor números: frente à situação-problema de descobrir a quantidade de brigadeiros que quatro receitas resultariam, Af e Am propuseram estratégias envolvendo a adição de $\mathbf{n}$ vezes o número de brigadeiros de uma receita e, ao mesmo tempo, adicionando o número que faltava para completar os 100 brigadeiros como requisitado na situação inicial (ver desenvolvimento, resultados e discussão das segundas e terceiras sessões, por exemplo: 20+20; decomposição de 20 em duas partes de 10 etc.).

Na quarta sessão, diante da situação-problema de encontrar o total de brigadeiros requeridos para a distribuição de seis doces, para cada uma das pessoas de um total de 11 , Af colocou sobre a mesa de trabalho seis palitos para representar os seis brigadeiros e explicou que, a cada vez que ela concluísse a contagem desses mesmos seis palitos, adicionando à contagem anterior, significaria a distribuição a cada pessoa. Como pode ser visto no desenvolvimento, resultados e discussão da quarta sessão, a pesquisadora propôs então que Am fosse registrando através de marcas no papel cada uma das contagens de Af e isso foi imediatamente aceito por ambos, de modo que a resistência inicial ao uso de registros não formais e ao material concreto foi superada. Essa estratégia foi repetida na sexta sessão, quando Af propôs o uso dos dedos para representar o multiplicador do número de bandejas, na situação de contagem do total de unidades. Ou seja: a partir daquele ponto, os participantes passaram a fazer uso do material concreto e de registros não formais como instrumento de apoio ao pensamento numérico, evidenciando o desenvolvimento da capacidade de reflexão e a autonomia.

Da mesma forma, Af e Am desenvolveram a noção de julgamento da razoabilidade de cálculos, identificado, quando os participantes propuseram mudança nos valores 
envolvidos em alguns cálculos, que requisitavam a divisão de quantidades. Diante da situação de quantos brigadeiros, de um total de 120 , cada uma das 100 pessoas poderia comer, Af e Am trocaram ideias sobre como resolver a situação com o uso de palitos para representar as pessoas e forminhas para representar os brigadeiros. Então, como descrito na quinta sessão, as tentativas sucessivas de distribuição de brigadeiros - tentativas estas mediadas pela pesquisadora - evidenciaram a tomada de consciência de Af e Am de que a distribuição não poderia ser aleatória: havia a necessidade de considerar a relação entre os dois conjuntos, isto é, o número de pessoas e o número de brigadeiros que caberia a cada uma. A partir dessa situação, houve uma mudança na natureza das interações entre os participantes: houve a adesão às estratégias sugeridas por um ou pelo outro no decorrer das sessões.

Podemos dizer que o desenvolvimento da quinta sessão trouxe uma repercussão importante para a sexta sessão: a tomada de consciência de Af de que, para saber o número total de unidades distribuídas em sete bandejas, bastaria saber o número de unidades de uma delas. Esse fato foi importante para o conjunto dos resultados das sessões, pois foi a primeira vez que apareceu a referência ao significado da multiplicação. Também foi nessa sexta sessão que Am demonstrou a tomada de consciência do significado do seu registro e a sua consequente avaliação (ver final do desenvolvimento, resultados e discussão da sexta sessão, Figura 12). Nos últimos minutos dessa mesma sexta sessão, Af se utilizou de cédulas de dinheiro que estavam disponíveis, como material para representar os brigadeiros (semelhante ao uso que vinha fazendo dos palitos), entretanto, sem considerar o significado das cédulas. Essa situação possibilitou que a pesquisadora retomasse as cédulas e introduzisse o seu significado como valor de medida monetária na sétima sessão.

Na sétima sessão, evidenciamos o desenvolvimento do julgamento da razoabilidade dos resultados de cálculos. Por exemplo: ao estabelecer, como proposto pela pesquisadora, 
a relação entre o conjunto de 20 brigadeiros e o valor de $\mathrm{R} \$ 20,00$, Af se deu conta que "se for de 5 em 5 vai dar 25! " (Ver desenvolvimento, resultados e discussão da sétima sessão). Ou seja, era preciso outro valor para as unidades dos brigadeiros, para que o problema pudesse ser resolvido.

$\mathrm{Na}$ oitava sessão, os participantes foram instigados a lidar com o reconhecimento do tamanho relativo dos números, quando, ao analisarem encartes de supermercados, foram convidados a considerar as quantidades expressas nas embalagens dos produtos para decidir quais iriam ser considerados no cálculo dos valores dos ingredientes necessários para produzir uma receita de brigadeiro. Tiveram que decidir entre o uso de uma embalagem de achocolatado de 400 gramas ou uma de 800 gramas, por exemplo. Precisaram perceber qual desses seria o mais adequado para ser adquirido, considerando a quantidade solicitada na receita. Nesta sessão, observamos que os participantes apresentaram dificuldade no manejo com números decimais e valores monetários.

Na nona sessão, Af e Am decidiram operar com os valores do sistema monetário, a partir de arredondamentos. Nesta sessão, evidenciamos o reconhecimento dos efeitos relativos de operações com números, quando Af sugeriu que Am modificasse o arredondamento que ele apresentou para o número $\mathrm{R} \$ 3,59$. O arredondamento proposto por Am foi $R \$ 4,00$, no entanto, a sugestão de Af foi pelo uso de $R \$ 3,60$ como valor de arredondamento. Isso mostrou que Af dominava o arredondamento, bem como a percepção de que com $\mathrm{R}$ \$ 3,60 resultaria, ao final, em um cálculo mais preciso e mais próximo de um cálculo sem os valores arredondados.

Na décima sessão, uma dificuldade evidenciada foi o fato de Am afirmar que os números $\mathrm{R} \$$ 9,40 e $\mathrm{R} \$$ 9,64 eram iguais. A pesquisadora incitou o participante a olhar para os números novamente e perceber que existia algo neles que os diferenciava. Am olhou atentamente e apresentou a seguinte afirmação: “Am - NÃO! É É SIM! SÓ QUE MUDOU 
OS CENTAVOS! (...) A parte dos reais é igual, mas os centavos não”. Essa fala indicou que a regulação, conferida pela pesquisadora, permitiu a Am perceber que, apesar da parte dos reais (parte inteira) ser igual nos dois números, o fato da parte decimal ser diferente, 40 no numeral 9,40 e 64 no número 9,64, conferia uma diferença entre os números. A argumentação da pesquisadora a respeito das diferenças ou semelhanças entre os números suscitou em Am a iniciativa de revisão de sua resposta, evidenciando a competência de análise e reflexão de suas próprias ações, ou seja, evidenciou o processo de autorregulação.

Nas sessões décima primeira e décima segunda, foi proposto aos participantes que eles representassem os valores dos ingredientes da receita de brigadeiro com o dinheiro de brinquedo e, na sequência, que registrassem esses mesmos valores no papel. Essa proposta, assim como discutido em nossa fundamentação teórica, visava que os participantes pudessem ter a experiência do movimento entre o uso do material concreto e o registro dessa representação, assim como partir do registro para a representação com o material concreto, de modo a propiciar a situação de checagem dos valores, que os participantes estavam manipulando nas situações de resolução de situação-problema. Esse procedimento permitiu ainda, que os participantes refletissem sobre a sua própria ação.

Durante esse procedimento, foi possível identificar que os participantes demonstraram algumas dificuldades referentes à formação dos números e de suas quantidades, bem como à comparação e identificação de valores relativos e absolutos nos números. Podemos exemplificar o que estamos dizendo com a afirmação de Am na sessão décima primeira e Af na sessão décima segunda, de que no valor $\mathrm{R}$ \$ 2,89 o algarismo nove era maior que o 8. Logo, não consideraram os valores relativos desses algarismos, somente os valores absolutos (ver desenvolvimento, discussão e resultados das sessões décima primeira e décima segunda). A mediação da pesquisadora ocorreu no sentido de levar Af e Am a compararem a representação em dinheiro com os registros realizados por eles 
mesmos a partir dessas representações. Esse procedimento lhes permitiu tomar consciência de que os algarismos podem assumir diferentes valores a depender da posição que ocupam, conforme vemos no extrato da transcrição décima segunda sessão: “Af - O oito, ele é 80. No caso que se botasse o zero no 9 o nove seria maior". Discutimos essa construção dos significados do valor dos algarismos nos numerais em na nossa fundamentação teórica no item sobre o SND (ver citação de Lerner e Sadovsky,1996).

Na décima terceira sessão, tivemos indícios que Af e Am já estavam mais familiarizados com a utilização das unidades monetárias para a realização dos cálculos. Citamos, por exemplo, o agrupamento de duas moedinhas de 50 com quatro de 25 para a formação de dois reais, pois Af, na primeira fase da pesquisa, não soube formar um real com as moedas que tinha a sua disposição. As competências relacionadas ao significado de números, desenvolvidas ao longo das sessões, permitiram aos participantes que utilizassem diversas estratégias de cálculo, diante do desafio de encontrar o valor da soma dos ingredientes da receita.

Assim, inicialmente, eles relataram dificuldade para a realização da operação de adição das moedas, como lhes foi proposto. No entanto, juntos, eles foram dialogando e a pesquisadora apenas confirmava ou completava o que diziam, até que Af e Am encontraram uma forma de resolver os cálculos. Apresentamos em seguida, um extrato desse diálogo:

Af - Você conta as moedas e eu as cédulas.

Am - Ah, que coisa fácil.

$\mathrm{P}$ - É uma opção. Vocês estavam dizendo que estava difícil.

Am - Já até sei o resultado daqui dos papéis. \{Estava se referindo às cédulas \}

$\mathrm{P}$ - Então faz. Am - 7 reais. Af - mas você conta as moedas e eu o dinheiro.

Como podemos ver no extrato, primeiramente Af e Am somaram as cédulas (parte inteira) e, em seguida, as moedas (parte decimal). Por iniciativa de Af, na sequência, eles agruparam as moedas de modo que pudessem operar com a maior quantidade de números 
inteiros ou números arredondados possíveis (ver desenvolvimento, resultados e discussão da décima terceira sessão).

Na última sessão, os participantes Af e Am se depararam com algo que talvez não conseguissem resolver e para o qual tivessem que reelaborar seus esquemas em busca da solução do problema apresentado, da mesma forma como propôs Muniz (2009). Sendo assim, tiveram que operar apenas com moedas e não podiam trocá-las por cédulas, o que lhes forçou a ter de operar com as partes decimais dos números. Essa era justamente a parte da qual vinham tentando se esquivar (ver desenvolvimento, resultados e discussão da décima quarta sessão). Ao terem que utilizar apenas moedas e também registrar esses valores no papel, Af e Am foram capazes de desenvolver e exercitar novas competências matemáticas, entre elas, a compreensão da função do uso da vírgula em números decimais e a adição e multiplicação desses números.

No final das sessões de intervenção, desenvolvemos uma entrevista como a realizada na primeira fase do nosso estudo. Assim, em ocasiões particulares para cada um dos participantes, abordamos os seguintes eixos: aprendizagens no quinto ano, aprendizagens em decorrências das experiências vivenciadas na intervenção, análise do caderno de Matemática. Sendo assim, decidimos dar voz a cada um deles a respeito do período da pesquisa. Realizamos entrevistas, semelhantes àquelas desenvolvidas por Fávero, Chiesa e Lopes (2015) sobre as vozes de estudantes em relação ao seu próprio desenvolvimento matemático. Tínhamos o interesse em saber: como elaboraram a experiência das sessões.

Ambos, Af e Am, referiram-se ao gosto pelo estudo da Matemática e também pelo apreço ao uso de materiais concretos nas resoluções matemáticas. Am e Af reconheceram que seus desempenhos em Matemática melhoraram. Am disse que a intervenção o ajudou não só em Matemática, mas segundo ele, até em português estava melhor. Isso indica que a 
autoconfiança, desenvolvida pelos êxitos em Matemática, se refletiu em motivação para a aprendizagem em outras disciplinas.

Af se referiu a uma mudança em seu comportamento na sala de aula. Afirmou que antes das intervenções não prestava atenção às explicações de sua professora, mas que passou a ter mais atenção a isso, e percebeu que os conteúdos de Matemática não eram tão difíceis como ela pensava. Ou seja, a crença cultivada que a Matemática era difícil impedia que Af tivesse motivação, sequer, para acompanhar as explicações de sua docente. Podemos dizer que essa fala justifica aquilo que já havíamos apresentado na fundamentação teórica, sobre a necessidade de se compreender a lógica subjacente aos conteúdos (Muniz, 2009). Logo, o processo de intervenção permitiu a Af compreender a lógica de conceitos mediados na intervenção. Esses conceitos foram, assim, incorporados aos seus esquemas mentais e isso a auxiliou a compreender conteúdos novos, que eram apresentados por sua professora.

Naquela ocasião, também tivemos a oportunidade de analisar o caderno. Essa análise inspirou duas atividades que foram resolvidas pelos participantes durante a entrevista. No caso de Af, uma resolução de problema envolvendo dúzias e multiplicação; e no caso de Am um algoritmo da multiplicação. Nessas atividades indicadas, Af e Am, relatavam dificuldades para as resoluções, mas logo se engajavam, demonstrando que as dificuldades já não eram empecilho para não resolver as tarefas, como observado na primeira fase de nosso estudo (a avaliação psicopedagógica).

Esses resultados das entrevistas nos permitiram retomar os resultados relativos às esferas dos atos da fala. Observamos mudanças quanto à presença dos atos entre as primeiras e as últimas sessões de intervenção. Nas primeiras sessões, pudemos identificar a predominância da esfera da informação, sendo caracterizada principalmente pelos atos de descrever e explicar. Nas sessões finais, em especial a partir da décima primeira sessão, foi 
possível observar uma maior presença das esferas da interação, com o predomínio dos atos de confirmar e completar e a esfera acional na qual predominaram os atos de incitar e propor.

As evidentes mudanças nos atos da fala nos permitiram concluir que houve uma modificação no que diz respeito à forma como os participantes interagiam com o outro participante, com a pesquisadora e com os conceitos mediados no decorrer das sessões. Passaram de uma interação passiva, na qual apenas respondiam às solicitações que lhes eram feitas, para uma postura ativa, na qual também eram capazes de propor, incitar, desafiar e completar as ações dos outros. Isso mostrou o quanto as regulações sociocognitivas foram importantes para o desenvolvimento dos participantes e como auxiliaram nas construções conceituais de todos os envolvidos.

Portanto, os dados das 14 sessões, acrescidos dos dados destas duas sessões finais individuais, nos permitiram afirmar que as atividades propostas atenderam nossos objetivos iniciais de evidenciar os processos de desenvolvimentos, colher dados sobre esses processos e também intervir nesses contextos. Defendemos que os resultados aqui descritos foram alcançados, principalmente, pela adesão à utilização de situaçõesproblemas como mediação dos significados e também por termos seguido a sequência de ações proposta por Fávero (1999), em que os participantes deviam manipular as representações e, em seguida, realizar o registro dessas representações. Outro ponto importante para o êxito das intervenções foi a sequência proposta por Fávero (2009a, 2009b, 2011) que sugere a realização da sessão de intervenção; em seguida, a sua análise; e, por fim, o planejamento da próxima sessão. Essa sequência nos permitiu propor situações-problemas que, de fato, podiam intervir nas dificuldades dos sujeitos e proporcionar desenvolvimento psicológico e de competências matemáticas. 


\subsection{Discussão Geral do Estudo}

Iniciamos nosso estudo nos referindo ao fato de que a evasão e a repetência são alguns dos elementos que causam a exclusão escolar. Com base em autores como Fávero e Carneiro Soares (2002), Pina Neves (2008), Fávero e Pina Neves (2009), Forero e Fávero (2010), Fávero (2011), Muniz (2009), Moro (2004), evidenciamos que, principalmente na Matemática, os alunos têm demonstrado dificuldades referentes a não compreensão dos conceitos mediados por seus professores, o que consequentemente têm contribuído para que apresentem maus resultados na escola. O que tem dificultado, muitas vezes, o acesso desses alunos aos níveis mais avançados de escolarização, contribuindo para a referida condição de exclusão.

Em nossa revisão bibliográfica, evidenciamos que os autores sugerem que as práticas de ensino da Matemática requerem mudanças. Eles apontam como alternativas para a melhoria do ensino, ações como: o encorajamento dos alunos para o uso de formas alternativas de cálculos e de registros; a proposição de situações-problemas; a utilização de materiais concretos que representem de forma coerente os objetos matemáticos; e o desenvolvimento da compreensão conceitual da Matemática, tanto por parte de alunos como de professores, em contraposição a práticas baseadas no treinamento de regras e algoritmos memorizados.

Estas questões nos motivaram a adotar a pesquisa de intervenção para este estudo, nos moldes propostos por Fávero (2000, 2001, 2005, 2009 2011, 2012). Uma proposta de pesquisa que nos permitiu identificar dificuldades conceituais em relação à Matemática escolar, mas que, ao mesmo tempo, nos possibilitou mediar conceitos e ainda propiciar o desenvolvimento de novas competências numéricas, junto aos dois sujeitos, Af e Am, repetentes e estudantes do quinto ano do Ensino Fundamental, que participaram deste estudo. 
Desse modo, desenvolvemos uma intervenção, concebendo, antes de tudo, que os indivíduos poderiam reconstruir seus esquemas mentais e ampliar suas competências. Nosso foco era adotar uma postura diferente daquela apregoada pelas instituições escolares e questionada por Fávero (2007, 2010). Postura essa que se limita a explicar as dificuldades dos sujeitos a partir de características pessoais, como, por exemplo, problemas familiares, falta de motivação ou falta de competências cognitivas. Filiadas a essas noções, acreditávamos que, mesmo nossos sujeitos sendo alunos de escola pública e com histórico de fracasso escolar, em decorrência da repetência, eram amplamente capazes para desenvolver competências matemáticas.

O modelo de análise dos dados coletados, que englobou a análise das notações e dos procedimentos dos participantes e a análise dos atos da fala dos interlocutores, permitiu-nos evidenciar mudanças na forma como os sujeitos lidavam com os conceitos em jogo nas sessões, evidenciando as dificuldades e as competências. Tal modelo possibilitou, ainda, evidenciar as particularidades das seguintes interações: 1) participante Af participante AM - conteúdos; 2) participante Af - pesquisadora - conteúdos; 3) participante Am - pesquisadora - conteúdos; 4) pesquisadora - participantes - conteúdos. Em outras palavras, foi-nos possível identificar as interações desenvolvidas na pesquisa, de acordo como o que é proposto por Fávero (2009b): Interações no formato de uma tríade e não de uma díade (ver item 1.4). Desse modo, foi possível perceber o impacto dessas interações nos processos de autorregulação e tomada de consciência de todos os envolvidos no processo de intervenção.

Por meio dessas análises, identificamos que os sujeitos Am e Af apresentaram, durante a fase de avaliação psicopedagógica (entrevista e Prova ECPN - Groupe Cimete, 1995) competências para: 1) relacionar as palavras-número às suas quantidades, 2) realizar cálculos mentais de pequenas quantidades, 3) adicionar ou subtrair a partir de uma 
quantidade já existente, 4) realizar contagem termo a termo, 5) cardinalizar, 6) investigar os estados iniciais ou transformações de cálculos aritméticos envolvendo pequenas quantidades. No entanto, os sujeitos Am e Af apresentavam dificuldades para a questão "N a mais que". Eles eram competentes na indicação de onde havia maior quantidade de fichas, mas quando convidados a realizar cálculos que pudessem levar alguém a ter uma quantidade "a mais que" o outro, lançavam mão da estratégia de acrescentar, desconsiderando a quantidade inicial. Identificamos também incompreensões quanto à lógica do Sistema de Numeração Decimal (uso do sistema posicional, valores relativos, valores absolutos, uso do numeral zero).

Evidenciamos, no entanto, na entrevista da avaliação psicopedagógica, duas particularidades relativas às dificuldades referentes ao SND. A primeira foi apresentada por Af quando apontou 111 como o valor relativo do algarismo 1 no numeral 158 (ver Figura 1, no item 2.4.1). A segunda foi apresentada por Am, que disse não saber responder as perguntas sobre os valores relativos ou absolutos dos números, devido ao fato de ter estudado esses conteúdos no ano anterior. Durante o procedimento de intervenção, no entanto, observamos, como descrito na discussão da décima segunda sessão, que Af indicou que no número 1,89 , o 8 era maior que o 9 , pois, naquela posição, ele valia 80 . $\mathrm{Na}$ entrevista após as sessões, Am percebeu que a cada casa decimal, os valores relativos dos números cresciam, o que o levou a concluir que no número 16.000, o 1 valia 10 mil. Ou seja, ambos os participantes desenvolveram a compreensão de que existe uma relação entre a casa decimal que um algarismo ocupa e o seu valor relativo.

A incompreensão da lógica do SND, apresentada pelos indivíduos na fase de avaliação psicopedagógica, nos indicou que ainda não haviam compreendido algumas das relações numéricas descritas por Fávero (2009a, 2009b) e Parker (2008). Por essa razão, em nossa intervenção, o foco esteve sempre direcionado para o desenvolvimento dos cinco 
componentes do sentido de número. Vimos que as atividades realizadas permitiram esse desenvolvimento ao longo das sessões, assim como descrevemos em nossa discussão geral das sessões. Os participantes foram demonstrando, pouco a pouco, a compreensão desses componentes e, consequentemente, desenvolvendo a compreensão da lógica do SND.

Quanto ao uso do numeral zero, vimos, na fase de avaliação, Af dizer que o zero não tinha valor algum e que estava no número apenas para preencher um espaço vazio. Contudo, na décima segunda sessão, ela soube dizer que com o uso do zero, o número 9 passaria a valer 90, assim como descrito no trecho da transcrição: “Af - O oito, ele é 80. No caso que se botasse o zero no 9 o nove seria maior. P - Ele ia ser quanto? Af - 90.”. Am, por sua vez, apresentou, na décima quarta sessão, vários indícios de que desenvolveu o entendimento da função do zero na formação dos números. Um desses exemplos está no extrato seguinte: “Am - se pôr o zero aqui, fica cinquenta. $\mathrm{P}$ - Do lado de lado né? Am - é. Tem que pôr desse lado aqui." Assim, podemos afirmar que esses dados nos permitem dizer que tanto Af como Am compreenderam que a presença do zero era capaz de modificar a quantidade que um número podia expressar.

De todas as atividades desenvolvidas junto aos participantes, o manejo de valores do sistema monetário mostrou-se como a que mais ofereceu desafios a serem vencidos por Af e Am, tanto nas fases de avalição como na de intervenção. Durante a avaliação, Af, apesar de ter identificado todos os valores das moedas que estava manuseando, não conseguiu utilizá-las coerentemente para formar a quantia de 1 real. Am, por sua vez, teve dificuldades para retirar $\mathrm{R} \$ 1,70$ de um montante, formado por uma moeda de 1 real, uma de 50 centavos, duas moedas de 10 centavos e uma de 5 centavos. Por várias tentativas, ele separou do montante de $\mathrm{R} \$ 2,00$, o valor de $\mathrm{R} \$ 1,75$ representado por uma moeda de 1 real, uma moeda de 50 e outra de 25 . O que sugeria dificuldades do sujeito quanto às várias possibilidades de composição e decomposição desses números. Somente depois de 
sugestões da pesquisadora, que propôs que ele recontasse os valores ou mesmo modificasse as moedas que ele achava que representavam os $\mathrm{R} \$ 1,70$, é que Am chegou a essa representação, fazendo uso de uma moeda de 1 real, uma de 50 e outras duas de 10 centavos.

Assim, nas sessões de intervenção, Af e Am desenvolveram a competência do manejo com o dinheiro. Ambos elaboraram procedimentos para a contagem de dinheiro e para a soma de valores. Am, por exemplo, percebeu que podia trocar uma moeda de cinco centavos por cinco moedas de um centavo continuando, dessa forma, a ter o mesmo valor que antes de trocar as moedas, como vimos nas sessões décima primeira e décima segunda. O uso do dinheiro, nas sessões de intervenção, permitiu a Af e Am, num primeiro momento, dúvidas quanto à utilização desses valores, principalmente com relação aos usos dos centavos e à diferenciação da parte inteira e decimal dos números racionais. Mas, em um segundo momento, lhes possibilitou a compreensão do uso da vírgula nos números decimais, assim como a criação de estratégias para a realização de cálculos com números não inteiros.

$\mathrm{O}$ uso do dinheiro trouxe para os participantes a possibilidade de relacionar conteúdos escolares às práticas do seu cotidiano. Os resultados que apresentamos são compatíveis com o estudo de Pina Neves e Fávero (2010). Essas autoras mostraram que a utilização de cédulas e moedas se configurou em uma proposta eficaz para a mediação dos conceitos matemáticos, em um estudo que desenvolveram com alunos repetentes. Esse tipo de material, assim como no estudo das referidas autoras, motivou Af e Am para o uso de cálculos mentais, estimativas e para a criação e utilização de algoritmos formais e não formais.

Durante toda a intervenção, principalmente naquelas situações que motivaram os sujeitos a produzir notações próprias ou utilizar procedimentos pessoais de cálculos, como 
descrito nas terceira, quarta e quinta sessões, confirmam a pertinência do que foi proposto em nossa fundamentação teórica a respeito das estratégias pessoais de cálculo (Fantinato, 2004; Moro, 2005). Ou seja, os nossos resultados corroboram com os desses estudos citados nos quais os participantes demonstraram melhor compreensão dos cálculos quando recorreram às estratégias não convencionais, quando comparados aos que utilizaram apenas algoritmos formalizados (Fávero \& Pina Neves, 2012; Coelho, 2008; Moro, 2004; Moro, Neves \& Carvalho, 2006)

Nossa intervenção nos mostrou que os participantes passaram a refletir e a rever seus procedimentos durante as resoluções de situações-problemas. Num primeiro momento apontavam respostas, mesmo que aleatórias, para as perguntas que lhes eram feitas. Com o desenvolvimento das sessões, eles passaram a definir estratégias de resolução dos problemas, antes de efetivamente resolvê-los. Esse fato confirma o que Vygotsky (1984) afirmou a respeito da reconstrução psicológica dos indivíduos e das mudanças dos meios para a realização de tarefas.

Por fim, ao analisarmos a voz de Af na entrevista, após as sessões, vimos que ela afirmou que ficou mais fácil entender Matemática após as intervenções e que, por isso, passou a prestar mais atenção nas aulas. Em outras palavras, ao desenvolver competências que não havia desenvolvido ao longo de sua escolarização, Af passou a encontrar sentido para as atividades da sala de aula. Esse dado é compatível com o que propõe Vergnaud (2009a) a respeito do fato que um conceito se desenvolve associado a outros conceitos, e também em relação ao sentido e significado dos conceitos, que se constroem uns em relação aos outros. Também se verifica uma referência clara sobre a relação entre compreensão conceitual e motivação para o ato de aprender.

Retomando, portanto, a proposta de Fávero (2001, 2002, 2009a, 2009b, 2011), salientamos a pertinência desse procedimento que não se preocupa apenas em descrever 
dificuldades, mas também em desenvolver competências e em promover o seu desenvolvimento por meio do processo de intervenção. A proposta de Fávero (2009a, 2009b, 2011, 2012) para o encadeamos das sessões, assim como nos referimos no método e na discussão geral das sessões, ou seja: a análise de uma sessão de intervenção antes de planejar e desenvolver a próxima, nos possibilitou a compreensão real do processo de desenvolvimento dos participantes. Com isso, acreditamos que esta pesquisa, pelos resultados alcançados, possa ser útil para inspirar professores a desenvolverem suas estratégias de intervenção diante das dificuldades dos seus alunos. Acreditamos que se trata de uma proposta profícua para aplicação em salas de aula regulares e também em salas de recursos que atendem alunos com desenvolvimento atípico.

Para finalizar, ressaltamos que nós também nos desenvolvemos e apresentamos mudanças em nosso desenvolvimento no decorrer das sessões de intervenção. Em primeiro lugar, tivemos que modificar o modelo de mediação ao qual estávamos filiadas. Tivemos que reelaborar nossas crenças e atitudes relacionadas ao modelo de mediação escolar, no qual a nossa preocupação principal era aferir acertos e erros e transmitir conhecimentos. Nossa perspectiva precisou mudar. Passamos, assim, a considerar os processos de desenvolvimento dos indivíduos e, com isso, vimos, pouco a pouco, a necessidade de fazer menos inferências nas respostas dos participantes, solicitar que revissem suas respostas e, até mesmo, controlar nossa ansiedade diante de procedimentos que, para nós, pareciam incoerentes, mas que indicavam o processo de construção do pensamento dos sujeitos. Passamos a entender que o erro também possibilita a compreensão e a construção conceitual. 


\subsection{Considerações Finais}

A inclusão e a exclusão são termos contrários, mas que caminham lado a lado em nosso sistema de ensino. Como evidenciamos em nossa pesquisa, nossos participantes, inclusos em um contexto escolar, vivenciam histórias particulares de exclusão em decorrência de seu desempenho ao longo do processo de escolarização. Repetência e incompreensão de conteúdos são apenas duas de várias dificuldades que poderíamos apontar.

Muitas são as iniciativas, Brasil afora, que visam mudanças na educação. A mais recente delas, em âmbito Federal, é o PNE (Plano Nacional de Educação). Um plano de vinte metas que visa, justamente, enfrentar as dificuldades e as desigualdades existentes no nosso sistema de ensino. Duas dessas metas podem ser discutidas por nós e relacionadas à nossa pesquisa.

A primeira delas é a meta dois ${ }^{1}$ do PNE, que se refere à inclusão das crianças e dos jovens no sistema de ensino e a garantia que concluam os seus estudos na idade correta, ou seja, sem atrasos. Uma meta bastante coerente, já que a própria Constituição Federal propõe em seu artigo $6^{\circ}$ que a Educação é um direito social. Contudo, não podemos esquecer que a simples inclusão dos alunos, nas escolas, por si só não garante a aprendizagem dos conteúdos escolares e, em especial, a aprendizagem da Matemática.

A segunda dessas metas, escolhidas por nós, é a meta sete ${ }^{2}$, que se refere justamente à melhoria da qualidade do ensino e da aprendizagem. Uma meta voltada para a melhoria dos escores dos alunos, nos resultados no IDEB (Índice de Desenvolvimento da

\footnotetext{
${ }^{1}$ Meta 2: universalizar o ensino fundamental de 9 (nove) anos para toda a população de 6 (seis) a 14 (quatorze) anos e garantir que pelo menos $95 \%$ (noventa e cinco por cento) dos alunos concluam essa etapa na idade recomendada, até o último ano de vigência deste PNE

${ }^{2}$ Meta 7: fomentar a qualidade da educação básica em todas as etapas e modalidades, com melhoria do fluxo escolar e da aprendizagem, de modo a atingir as seguintes médias nacionais para o IDEB: 6,0 nos anos iniciais do ensino fundamental; 5,5 nos anos finais do ensino fundamental; 5,2 no ensino médio.
} 
Educação Básica). Uma meta que baseia a qualidade da educação nos resultados de uma avaliação, ou seja, na aferição de erros e acertos. É claro que não estamos aqui para discordar dessa meta, ou dos seus instrumentos de avaliação, mas, sim, para utilizá-la como elemento de reflexão sobre as atitudes particulares que se realizam no dia a dia das escolas e que, se multiplicadas por todo o país, podem resultar em uma educação de qualidade.

De fato, mudanças precisam acontecer no ensino como um todo, e na Matemática, que é o nosso foco de estudo, também. Mudanças, essas, que possam garantir que as nossas crianças, nossos jovens e também os adultos venham a concluir o ensino básico com sucesso, de modo que realmente tenham consciência dos conteúdos mediados pela escola. Poderão, assim, chegar aos níveis mais elevados de escolarização.

Em referência especificamente ao campo da Matemática, o desejo é que os alunos dominem os conceitos, desde os mais simples, como é o caso do conceito e sentido de número, até os mais complexos. Esperamos, por exemplo, que o ensino do SND, e de todos os outros conceitos da Matemática, não seja reduzido ao ensino de regras. Mas que aos alunos seja dada a oportunidade de uma experiência real com esses objetos matemáticos. Que eles possam, assim como Af e Am fizeram, ao longo do nosso estudo, relacionar fatos do seu cotidiano às lições resolvidas e aprendidas na escola.

É nesse sentido, que a proposta de Fávero (2000, 2001, 2009a, 2009b, 2011) é realmente radical, como se refere a própria autora em Fávero (2010). Uma proposta que evidencia não somente o lado negativo da realidade dos sujeitos (dificuldades), mas também o lado positivo (competências). Como pudemos mostrar ao longo desta dissertação, essa é uma proposta que oferece muitos benefícios às construções do conhecimento, por parte dos indivíduos e oferece ao mediador (professor, pesquisador) os meios para tornar viáveis essas construções. É por esse motivo que acreditamos ser esta 
pesquisa, para a comunidade acadêmica e para profissionais da educação e psicologia, um exemplo de como embasar as práticas profissionais na direção do cumprimento das metas do PNE.

Antes de encerramos nossas considerações finais, apontamos que houve limitações em nosso estudo. $\mathrm{O}$ que acreditamos ser bom, pois serve de motivação e inspiração para futuros pesquisadores darem continuidade aos caminhos por nós percorridos. Sendo assim, apontamos como uma limitação do nosso estudo o fato que poderíamos ter realizado mais atividades no âmbito das sessões de intervenção que priorizassem as transformações de representações semióticas, assim propõe Duval (2012, 2013), de modo que os participantes pudessem refletir mais sobre os tratamentos e as conversões. Isso nos permite retomar Vergnaud (2009a), que explica que as construções conceituais requerem um longo período para se consolidarem. $\mathrm{O}$ que confirma que a nossa pesquisa não podia atender a todas as necessidades apresentadas pelos nossos participantes, haja vista o prazo limitado que tínhamos para desenvolver as atividades.

Portanto, considerando as necessidades de mudanças no ensino de Matemática, o foco para o cumprimento das metas do PNE e ainda as limitações do nosso estudo, concluímos que o nosso desafio como profissional da educação em defesa de uma compreensão conceitual da Matemática é muito grande. Analisando o impacto desta pesquisa para a nossa própria atuação como profissional da Secretaria de Educação, na qual atendemos alunos com dificuldades de aprendizagem, podemos dizer que somos chamadas a refletir sobre os processos de desenvolvimentos dos alunos, quando nos é solicitada uma solução para os problemas de rendimento escolar.

Um dos principais pontos desse processo diz respeito à mudança na forma como encarávamos os erros em produções escolares e como faremos daqui para frente. Levaremos para nossa vida profissional a seguinte citação de Pina Neves e Fávero (2010): 
Os resultados também evidenciaram que os estudantes, não analisavam o que produziam; não avaliavam se suas notações eram pertinentes ao contexto das situações; não apresentavam suas notações inacabadas para a análise e sentiam-se seguros, apenas, para apresentar as notações que eles avaliavam corretas. Esses comportamentos sinalizam que a escola tem adotado pouco e/ou não tem adotado a análise das notações de escolares por parte dos professores durante a prática docente. (Pina Neves \& Fávero, 2010, p.5)

Esse trecho é compatível com os dados apresentados por nossos participantes na fase de avaliação e também nas primeiras sessões de intervenção, nas quais se sentiam incomodados ao errar e que, muitas vezes, nem mesmo queriam tentar resolver as questões propostas, justamente devido ao risco do erro. Podemos destacar o quanto foi importante para os nossos participantes da pesquisa, ações simples como conferir se a contagem que haviam realizado estava correta, ou revisarem os passos de suas resoluções para encontrar o que estava incoerente em seus procedimentos. Isso nos ensinou que a nossa tarefa de analisar as produções de alunos com dificuldades de aprendizagem, ou mesmo quando orientamos pais e docentes quanto aos problemas de seus filhos ou alunos, jamais poderá ser igual ao modo como procedíamos antes de realizarmos esta pesquisa. Três perguntas serão norteadoras em nossa atuação profissional a partir deste estudo: 1 - Quais competências esse indivíduo com dificuldades apresenta? 2 - O que a produção de um aluno com dificuldades pode nos dizer sobre o seu desenvolvimento cognitivo? 3 - O que esse sujeito tem a nos dizer a respeito de suas próprias dificuldades? 


\section{Referências}

Alberbaz, J. M. (2009). Mapas de um percurso construído por crianças de 8 anos: interações e aprendizagens lógico-espaciais. Educação em Revista, 25, 103-122.

Almouloud, S. A., Manrique, A. L., Silva, M. J. F., \& Campos, T. M. M. (2004). A geometria no ensino fundamental: reflexões sobre uma experiência de formação envolvendo professores e alunos. Revista Brasileira de Educação, 27, 94-108.

Araújo, P. M., \& Ferreira, P. R. S. (2008). Ensinando subtração para pessoas com deficiência mental com base em relações de equivalência de estímulos. Psicologia: teoria e pesquisa, 24, 313-322.

Barbosa, H. H. (2014). Conceitos matemáticos iniciais e linguagem: um estudo comparativo entre crianças surdas e ouvintes. Educação e Pesquisa, 40, 163-179.

Barbosa, H. H. J. (2007). Sentido de número na infầncia: uma interconexão dinâmica entre conceitos e procedimentos. Paidéia, 17, 181-194.

Batista, A. M. S. B., \& Spinillo, A. G. (2008). Nem todo material concreto é igual: a importância dos referentes na resolução de problemas. Estudos de Psicologia, 13, 1321.

Berch, D. B. (2005) Making Sense of Number Sense: Implications for Children With Mathematical Disabilities. Journal of learning disabilities, 38, 333-339.

Bispo, R., Ramalho, G., Henriques, N. (2008). Tarefas matemáticas e desenvolvimento do conhecimento matemático no $5^{\circ}$ ano de escolaridade. Análise Psicológica, 26, 3-14.

Bonfim, R. A. F. (2005). Aquisição de conceitos numéricos na sala de recursos: relato de uma pesquisa de intervenção (Dissertação de mestrado não publicada). Universidade de Brasília, Brasil.

Brandt, C. F. (2002). Desenvolvimento histórico do Sistema de Numeração Decimal e do processo de aprendizagem a partir das recentes concepções matemático-didáticas: Erro e obstáculo Epistemológico. Contrapontos, 6, 423-437. Acessado em 10/07/2015 em : http://www6.univali.br/seer/index.php/rc/article/view/183 
Brandt, C. F., \& Rosso, A. J. (2010). Abstração Reflexionante na Construção do Sistema de Numeração Decimal. Educação matemática pesquisa, 12, 310-334. Acessado em 10/07/2015, em: http://revistas.pucsp.br/index.php/emp/article/view/2814

Brandt, C. F., Camargo, J. A, \& Rosso. A. J. (2004). Sistema de Numeração Decimal: operatividade discente e implicações para o trabalho docente. Zetetiké, 12, 89-124. Acessado em 20/01/2015, em:https://www.fe.unicamp.br/revistas/ged/zetetike/article/view/2467

Brasil. (2013). Prova Brasil: SAEB. Legislação - Portaria no 482.07062/2013. Brasília: MEC, Inep. Acessado em 19/10/2015, em: http:/download.inep.gov.br/ educacao_basica/prova_brasil_Saeb/legislacao/2013/portaria_n_482_07062013_mec_i nep_saeb.pdf

Brasil. (2014). Planejando a Próxima Década Conhecendo as 20 Metas do Plano Nacional de Educação. Brasília: MEC, Inep. Acessado em 25/10/2015, em: http://pne.mec.gov.br/images/pdf/pne_conhecendo_20_metas.pdf

Brasil. (2014). Avaliação Nacional da Alfabetização - ANA Resultados Finais, INEP/MEC. Acessado em 19/10/2015, em: http://portal.inep.gov.br/web/saeb/ana/resultados.

Bzuneck, J. A., Megliato, J. G. P., \& Rufini, S. (2013). Engajamento de adolescentes nas tarefas escolares de casa: uma abordagem centrada na pessoa. Revista Semestral da Associação Brasileira de Psicologia Escolar e Educacional, 17, 151-161.

Cechi, M. B. C., Costa, A. C., \& Dorneles, B. V. (2013). Ensino de Fatos Aritméticos para Escolares com Deficiência Intelectual. Revista Brasileira de Educação Especial, 19, 79-92.

Chabrol, Claude., \& Bromberg, Marcel (1999). Préalables à une classification des actes de parole. Psychologie Française, 44, 291-306.

Coelho, J. P. (2008). Sucesso e insucesso na Matemática no final da escolaridade obrigatória, eis a questão! Análise Psicológica, 26, 663-678 
Corona, D.C. (2010). The development of number sense in second grade students: A comparison of two instructional programs. In: Partial Fulfillment of the Requirement for the Degree of Master of Education. Heritage University, Washington, EE.UU.

Correa, J. (2004). A resolução oral de tarefas de divisão por crianças. Estudos de Psicologia, 9, 145-155.

Cruz, V. (2014). Desenvolvimento cognitivo e aprendizagem da Matemática. Análise Psicológica, 1, 127-132.

Curi, E., Santos, C. A. B. \& Rabelo, M. H. M. (2013). Procedimentos de resolução de alunos de $5^{\circ}$ ano revelados em itens do Saeb com relação ao Sistema de Numeração Decimal. Revista Brasileira de Estudos Pedagógicos, 94, 211-231. Acessado em 11/10/2015, em:www.scielo.br/pdf/rbeped/v94n236/11

Damiani, M. F. (2006). Discurso pedagógico e fracasso escolar. Ensaio: Avaliação e Políticas Públicas em Educação, 14, 457-478. Acessado em 18/04/2014, em: http://www.scielo.br/scielo.php?script=sci_arttext\&pid=S0104-40362006000400004

Lima, C. N. M. F., \& Nacarato, A.M (2009). A investigação da própria prática: mobilização e apropriação de saberes profissionais em Matemática. Educação em Revista, 25, 241266.

Doise, W., \& Mugny, G. (1981). Le développement social de l'intelligence. Paris: Inter Editions.

Duval (1995) Sémiosis et pensée humaine. Berna: Peter Lang.

Duval, R. (2012). Registros de representação semiótica e funcionamento cognitivo do pensamento. Revemat: R. Eletr. de Edu. Matem., 07(2), 266-297. EISSN 1981-1322. Acessado em 03/09/2015, em: http://dx.doi.org/10.5007/1981-1322.2012v7n2p266.

Duval, R. (2013). Registros de representações semióticas e funcionamento cognitivo da compreensão em Matemática. In S. D. A. Machado (Org). Aprendizagem em Matemática. (pp.11-33). Campinas: Papirus.

Groupe Cimete (1995). Compétences et incompétences en arithmétique. Une aide au diagnostic et à l'action pédagogique particullièrement destinée aux entants affectés de 
difficultés sévères d'apprentissage. Anae, Hors Série, 58-63. Tradução Professora Doutora Maria Helena Fávero (IP/UNB).

Fantinato, M. C. C. B. (2004). A construção de saberes matemáticos entre jovens e adultos do Morro de São Carlos. Revista Brasileira de Educação, 27, 109- 124.

Faria P. C., Moro M. L. F., \& Brito, M. R. F. (2008). Atitudes de professores e futuros professores em relação à Matemática. Estudos de Psicologia, 13, 257-265.

Fávero, M. H. (2000). Regulações cognitivas e metacognitivas do professor de primeiro grau: Uma questão para a articulação entre a psicologia do desenvolvimento e a psicologia da educação matemática [Resumo]. Em Sociedade Brasileira de Psicologia (Org.), Resumos de comunicações científicas, XXX Reunião da Sociedade Brasileira de Psicologia (pp. 11-12) Brasília-DF.

Fávero, M. H. (2001) Regulações cognitivas e metacognitivas do professor: uma questão para a articulação entre a psicologia do desenvolvimento adulto e a psicologia da educação matemática. In Sociedade brasileira de Psicologia da Educação Matemática, Sociedade Brasileira de Educação Matemática (Org.). Simpósio Brasileiro de Psicologia da Educação Matemática, 1, (pp.187-197). Curitiba: Editora da UFPR. Anais (trabalhos completos).

Fávero, M. H. (2002). A aquisição da Matemática e a intervenção psicopedagógica. Simpósio: deficientes uma articulação entre a teoria e a prática. Artigo apresentado no I Congresso Brasileiro, Psicologia: Ciência e Profissão. São Paulo, SP.

Fávero, M. H. \& Souza, C. M. S. G. (2001). A resolução de problemas em física: revisão de pesquisa, análise e proposta metodológica. Investigações em Ensino de Ciências, 6, 143-196.

Fávero, M. H. (2003). A aquisição conceitual em condições especiais: articulação entre pesquisa e intervenção psicopedagógica. In: XXXIII Reunião Anual da Sociedade Brasileira de Psicologia. Psicologia: Compromisso com a Vida, 33. (pp. 83-84). (Resumos) Belo Horizonte, MG: SBP.

Fávero, M. H. (2005). Desenvolvimento, mediação semiótica e representações sociais. Psicologia: Teoria e Pesquisa, 21, 17-25. 
Fávero, M.H. (2007). Psychopedagogic practice in school inclusion and in research in the development of numeric competence. In: Eduardo Macera Martinez y César Augusto Pérez Gamba (Eds.). Anais da XII Conferencia Interamericana de Educatión Matemática. Investigación Internacional en Educación Matemática, 1. (pp. 1-9) Santiago de Querétaro, México: Edebéméxico.

Fávero, M. H. (2009a). La Psicología del conocimiento y la construcción de competencias conceptuales en la escuela. Revista Internacional Magistério Educación e Pedagogia, $39,18-22$.

Fávero, M. H. (2009b). Os fundamentos teóricos e metodológicos da psicologia do conhecimento. In M. H. Fávero \& C. Cunha (Eds.), Psicologia do conhecimento: $O$ diálogo das ciências e a cidadania. (9-20). Brasília: Liber Livro.

Fávero, M. H. (2010). Resolução de problemas, surdez e a língua de sinais uma questão para a psicologia do conhecimento e para a educação matemática. Artigo apresentado para o X Encontro Nacional de Educação Matemática, Salvador, BA. Acessado em 03/09/2015 em http://www.lematec.net/CDS/ENEM10/artigos/MR/MR15_Favero.pdf

Fávero, M. H. (2011). A pesquisa de intervenção na psicologia da Educação Matemática: aspectos conceituais e metodológicos. Educar em Revista, 1, 47-62.

Fávero, M. H. (2012). A pesquisa de intervenção na construção de competências conceituais. Psicologia em Estudo, 17, 103-110.

Fávero, M. H (2014). Psicologia e conhecimento. Subsídios da Psicologia do desenvolvimento para a análise do ensinar e do aprender. Brasília. Editora UnB.

Fávero, M. H., \& Abrahão, L. M. (2006). Malhando o gênero: O grupo focal e os atos da fala na interação de adolescentes com a telenovela. Psicologia. Teoria e Pesquisa, 22, 175-182.

Fávero, M. H., \& Soares, M. T. C. (1998). A leitura do adolescente: mediação semiótica e a compreensão textual. Psicologia: Teoria e Pesquisa, 14, 229-240. 
Fávero, M. H., \& Soares, M. T. C. (2002). Iniciação escolar e a notação numérica: Uma questão para o estudo do desenvolvimento adulto. Psicologia: teoria e pesquisa, 18, 43-50.

Fávero, M.H., Chiesa, A.A.P., \& Lopes, M.J.F.C. (2015, setembro). Students’ Voices On Difficulties In Mathematics At School: Inclusion And Psychopedagogical Practice. In 17th European Conference On Developmental Psychology, Braga, Portugal.

Fávero, M. H., \& Oliveira, D. (2004). A construção da lógica do sistema numérico por uma criança com Síndrome de Down. Educar, 23, 65-85.

Fávero, M. H., \& Pimenta, M. L. (2006). Pensamento e Linguagem: A língua de sinais na resolução de problemas. Psicologia: Reflexão e crítica, 19, 225-236.

Fávero, M. H., \& Pina Neves, R. S. (2009). Competências para resolver problemas e para analisar a resolução de problemas. Revista Semestral da Associação Brasileira de Psicologia Escolar e Educacional (ABRAPEE), 13, 113-124.

Fávero, M. H., \& Pina Neves, R.S. (2012). A divisão e os racionais: revisão bibliográfica. Zetetiké, 20, 33-67.

Fávero, M. H., \& Pina Neves, R. S. (2013). A docência universitária como lócus de pesquisa da psicologia do desenvolvimento adulto. Revista Semestral da Associação Brasileira de Psicologia Escolar e Educacional, 17, 319-328.

Ferreira, E. B., Soares, A. B., \& Lima, J. C. (2008). O resgate das demonstrações: uma contribuição da Informática à formação do professor de Matemática. Revista Semestral da Associação Brasileira de Psicologia Escolar e Educacional (ABRAPEE), $12,381-389$

Forero, Y. R., \& Fávero, M. H. (2010). La resolución de situaciones problema que involucran conceptos estadísticos: un estudio que articula dados cognitivos, género e implicaciones educativas. Revista Iberoamericana de Educación Matemática, 24, 2743.

Freitas, M. T. M., \& Fiorentini, D. (2008). Desafios e potencialidades da escrita na formação docente em Matemática. Revista Brasileira de Educação, 13, 138-149. 
Fuentes, V. L. P., Lima, R., \& Guerra, D.S. (2009). Atitudes em relação à Matemática em estudantes de Administração. Revista Semestral da Associação Brasileira de Psicologia Escolar e Educacional (ABRAPEE), 13, 133-141.

Fuson, K. C. (2009). Avoiding misinterpretations of Piaget and Vygotsky: Mathematical teaching without learning, learning without teaching, or helpful learning-path teaching? Cognitive Development, 24, 343-361.

Gaspar, M. F. R. F. (2004). Aprender a contar, aprender a pensar: As sequências numéricas de contagem abstrata construídas por crianças portuguesas em idade pré-escolar. Análise psicológica, 1, 119-1138.

Gelmam, R. \& Gallistell, C. R. (1978). The children understanding of number. Cambridge: Harvard University Press.

Gomes, C. G. S. (2007). Autismo e ensino de habilidades acadêmicas: adição e subtração. Revista Brasileira de Educação Especial, 13, 345-364.

Grando, R. C., Nacarato, A. M., \& Gonçalves, L. M.G. (2008) compartilhando saberes em geometria: investigando e aprendendo com nossos alunos. Caderno Cedes, 28, 39-56.

Groenwald, C. L. O., \& Nunes, G. S. (2007). Currículo de Matemática no ensino básico: a importância do desenvolvimento dos pensamentos de alto nível. Relime, 10, 97-116.

Guimarães, G. (2012, Outubro). O uso de recursos didáticos na aprendizagem. In $V$ Seminário Internacional de Pesquisa em Educação Matemática, Petrópolis, Brasil.

Lerner. D. \& Sadovsky, P. (1996). O sistema de numeração: um problema didático. In C. Parra \& I. Saiz (Orgs.). Didática da Matemática: reflexões psicopedagógicas (pp.73155). Porto Alegre: Artes Médicas.

Lessa, M. M. L., Falcão, J. T. R. (2005). Pensamento e Linguagem: Discussão no campo da Psicologia da educação Matemática. Psicologia: reflexão e crítica, 18, 315-322.

Lima, C. N. M. F., \& Nacarato, A. M. (2009). A investigação da própria prática: Mobilização e apropriação de saberes profissionais em Matemática. Educação em Revista, 25, 241-266. 
Loos, H. (2004). Ansiedade e aprendizagem: um estudo com díades resolvendo problemas algébricos. Estudos de Psicologia, 9, 563-573.

Lorena, A. B., Castro-Caneguim, J. F., \& Carmo, J. S. (2013). Habilidades numéricas básicas: Algumas contribuições da análise do Comportamento. Estudos de Psicologia, $18,439-446$.

Loth, M. H. M., \& Silva, A. M. (2013). Tarefas Aritméticas para o $6^{\circ}$ ano do Ensino Fundamental. Bolema, 27, 451-465.

Magina, S. A. (2011). A pesquisa na sala de aula de Matemática das séries iniciais do Ensino Fundamental. Contribuições teóricas da psicologia. Educar em Revista, n. esp., 63-75.

Mendonça, T. M., Pinto, S. M., Carzola, I.M., \& Ribeiro, E. (2007). As estruturas aditivas nas séries iníciais do ensino fundamental: um estudo diagnóstico em contextos diferentes. Revista Latinoamericana de Investigación en Matemática Educativa, 10, 219-239. Acessado em 02/05/2014, em:

http://www.scielo.org.mx/pdf/relime/v10n2/v10n2a3.pdf

Ministério da Educação. (2004). Ensino fundamental de nove anos - orientações geraisBrasília: Acessado em 02/05/2014, em: http://portal.mec.gov.br/seb/arquivos/pdf/Ensfund/ noveanorienger.pdf

Moro, M. L. F. (2004). Notações da Matemática infantil: Igualar e repartir grandezas na origem das estruturas multiplicativas. Psicologia: Reflexão e crítica, 17, 251-266.

Moro, M. L. F. (2005). Estruturas Multiplicativas e Tomada de Consciência: Repartir para Dividir. Psicologia Teoria e prática, 21, 217-226.

Muniz, C. A (2014). A criança como protagonista de sua aprendizagem do Sistema de Numeração Decimal. In A. M. Miguel. Sistema de Numeração Decimal no ciclo de alfabetização (pp.4-6). Acessado em 15/07/2015, em: http://tvescola.mec.gov.br/tve/salto/edition;jsessionid=17B4BBD44DF526EC9F0FBC B9295C826F?idEdition=8171 
Muniz, C. A. (2009). A produção de notações matemáticas e seu significado. In M. H. Fávero \& C. Cunha (Eds.). Psicologia do conhecimento: O diálogo das ciências e a cidadania (pp. 115-143). Brasília: Liber Livro.

Neves, M. C., \& Carvalho, C. (2006). A importância da afetividade na aprendizagem da Matemática em contexto escolar: Um estudo com alunos do $8^{\circ}$ ano. Análise Psicológica, 24, 201-215.

Nogueira, C. M. I \& Pavanello, R. M. (2008). A Abstração Reflexionante e a Produção do Conhecimento Matemático. Bolema, 30, 111 - 130. Acessado em 23/07/2015, em: http://www2.rc.unesp.br/bolema/?q=node/51

Nogueira, C. M. I. (2011). Pesquisas atuais sobre a construção do conceito de número: para além de Piaget? Educar em Revista, num. esp., 109-124.

Nunes, T., \& Bryant, P. (1997) Crianças Fazendo Matemática. Porto Alegre: Artes Médicas.

Osti, A., \& Brenelli, R. P. (2013) Análise comparativa das relações entre ensino e aprendizagem por professores e alunos. Revista Semestral da Associação Brasileira de Psicologia Escolar e Educacional, 17, 55-63.

Otaviano, A. B. N., Alencar, E, M, L, S., \& Fukuda, C. C. (2012). Estímulo à criatividade por professores de Matemática e motivação do aluno. Revista Semestral da Associação Brasileira de Psicologia Escolar e Educacional, 16, 61-69.

Parker, R. (2008). Mathematics education collaborative. Acessado em: November 10, 2008, from Mathematics education collaborative, em: http://www.mecmathematics.org.

Piaget, J. (1977). A tomada de Consciência. São Paulo: Editora da Universidade de São Paulo.

Piaget, J. (1965). Estudos Sociológicos. Rio de Janeiro: Forense.

Piaget, J. (1978). Fazer e compreender. São Paulo: Editora da Universidade de São Paulo.

Piaget, J. (2009). Seis estudos de Psicologia. Rio de Janeiro: Forense Universitária. 
Piaget, J. \& Szeminska (1975). A gênese do número na criança. Rio de Janeiro: Zahar Editores. http://www.lematec.net/CDS/ENEM10/artigos/MR/MR15_Favero.pdf

Pina Neves, R. S. (2008). A divisão e os números racionais: uma pesquisa de intervenção psicopedagógica sobre o desenvolvimento de competências conceituais de alunos e professores. (Tese de doutorado não publicada). Universidade de Brasília, Brasília.

Placha, K. C., Moro, M. L. F. (2009). Problemas de Produto Cartesiano, Raciocínio Combinatório e Intervenção do Professor. Psicologia: Teoria e Pesquisa, 25, 007-017.

Ponte, J. P. (2003). O ensino da Matemática em Portugal: Uma prioridade educativa? In $O$ ensino da Matemática: Situação e Perspectivas (pp. 21-56). Lisboa: Conselho Nacional de Educação.

Ribeiro, M. R. (2011). Abordagem aos números decimais e suas operações: a importância de uma eficaz navegação entre representações. Educação e Pesquisa, 37, 407-422.

Rodrigues, C. I., Sousa, M. C., \& Carmo, J. S. (2010). Transtorno de conduta TDAH e aprendizagem da Matemática: um estudo de caso. Revista Semestral da Associação Brasileira de Psicologia Escolar e Educacional (ABRAPEE), 14, 193-201.

Rossit, R. A. S., \& Goyos, C. (2009). Deficiência intelectual e aquisição matemática: currículo como rede de relações condicionais. Revista Semestral da Associação Brasileira de Psicologia Escolar e Educacional (ABRAPEE), 13, 213-225.

Rosso, T. R. F., \& Dorneles, B. V. (2012). Contagem numérica em estudantes com síndromes de X-Frágil e Prader-Willi. Revista Brasileira de Educação Especial, 13, 231-244.

Senna, M. T. T. R., Dornelles, B. V., \& Yunes, M. A. M. (2013). Conceitos numéricos na educação infantil: uma pesquisa etnográfica. Educação e realidade, 38, 227-248.

Skovsmose, O. (2000, Abril). Cenários de Investigação. Em Reunião Anual da American Educational Research Association (AERA), New Orleans.

Skovsmose, O. (2009). Preocupações de uma matemática crítica. In M. H. Fávero \& C. Cunha (Eds.). Psicologia do conhecimento: $O$ diálogo das ciências e a cidadania (pp. 101-114). Brasília: Liber Livro. 
Silva, P. A., \& Santos, F. H. (2011). Discalculia do desenvolvimento: Avaliação da representação numérica pela Zareki-R. Psicologia: Teoria e Pesquisa, 27, 169-177.

Tian, W., Jimarkson, P. \& Singhasiri, W. (2011). Designing a Transcription System for Face-to-face PhD Supervisory. A selective-specificity model. Procedings of the Internacional conference: Doing Research in Applied Linguistics. Acessado em 04/04/2014, em: http://arts.kmutt.ac.th/dral/PDF\%20CD\%20on\%20Web/108119_Designing_a_Transcription_System_for_Face-to-face.pdf

Vergnaud, G. (1986). Piaget y la Didactica: algunas ideas fundamentales de Piaget en torno a la didactica. Perspectivas, 26,196-207.

Vergnaud, G. (1990). Psicologie du développement et didactique des mathématiques. Un exemple:les structures additives. Petit, 10, 51-69.

Vergnaud, G. (1991). El Niño, las Matemáticas y la Realidad: problemas de la enseñanza de las matemáticas en la escuela primaria. México: Editorial Trillas.

Vergnaud, G. (2009a). A contribuição da psicologia nas pesquisas sobre a educação científica, tecnológica e profissional do cidadão. In M. H. Fávero, \& C. Cunha, (Eds.), Psicologia do conhecimento: O diálogo das ciências e a cidadania (39-60). Brasília: Liber Livro.

Vergnaud, G. (2009b). A criança, a Matemática e a realidade: Problemas no ensino da Matemática na escola elementar. (Adobe Digital Editions) ISBN: 9788573352306.

Vergnaud, G., Cortes, A. E. \& Favre -Artigue, P. (1987) Introduction de l'algèbre auprès de débutants faibles: Problèmes épistémologiques et didactiques. Em G. Vergnaud, G. Brousseau \& M. Hulin (Orgs.), Didactique et acquisition des connaissances scientifiques: Actes du coloque de sèvres (pp. 259-280). Sèrvres: La Pensée Sauvage.

Vieira, D.O. (2002). A aquisição do conceito de número em considerações especiais: a sindrome em questão. (Dissertação de mestrado não publicada). Universidade de Brasília. Brasil. 
Vieira, G. A \& Zaidan, S. (2013). Sobre o conceito de prática pedagógica e o professor de Matemática. Paidéia 10, 33-54.

Vygotsky, L. S (1984). Psicologia Pedagógica. São Paulo. Editora Martins Fontes.

Vygotsky, L. S (2009). A Construção social da mente. São Paulo. Editora Martins Fontes.

Yang, D. C. (2003). Teaching and learning number sense - an intervention study of fifth grade students in Taiwan. International Journal of Science and Mathematics Education, 1, 115-134.

Yang, D. C., Li, M. F., \& Li, W. J. (2008). Development of a computerized number sense scale for 3-rd grades: Reability and validity analysis. International Electronic Journal of Mathematics Education, 3, 110-124. 77 
Anexo 1 - Aprovação do Projeto de Pesquisa pelo CEP (Conselho de Ética em

\title{
Pesquisa
}

\author{
INSTITUTO DE CIENCIAS \\ HUMANAS / UNIVERSIDADE \\ DE BRASILIA / CAMPUS
}

\section{PARECER CONSUBSTANCIADO DO CEP}

\section{DADOS DO PROJETO DE PESQUISA}

Titulo da Pesquisa: A PESQUISA DE INTERVENCAO PSICOLOGICA NA CONSTRUCAO DE COMPETENCLAS MATEMATICAS:UM ESTUDO COM ALUNOS DO $5^{\circ}$ ANO DO ENSINO FUNDAMENTAL

Peequlasdor: Maria Julana de Fretas Carvaho Lopes

Area Tematica:

Versas: 3

CAAE: 38811214.6 .0000 .5540

Inatitulç3o Proponente: instituto de Psicologa -UNE

Patrocinador Principal: Financiamento Proprio

\section{DADOS DO PARECER}

Numero do Parecer: 965.654

Data da Relatoria: 19/02/2015

\section{Apreeentacaso do Projeto:}

Resultados de pesquisas nacionais e internacionais tem indcado que o ensino da matematica tem se pautado pela utilzaçato de regras e algortimos formalizados. Ooserva-se que 06 alunos apresentam uma incompreensalo da logica do sistema de numeraçao decimal. Como atternativa a esses algoritmos formalzados, 06 alunos produzem suas proprias notaçbes para resoluç̧o de situaçes propostas por professores. Contudo, esses procedimentos proprios dos alunos, que representam o raciocinio, na siluaçb em questâo, s\$o, na maiorla das vezes, desqualifcados e rejeltados pelos docentes. Reforçando essa conjuntura, as pubicapbes nos periodcos de Psicologa e Eoucaço aportam para um baixo desempenho em matematica, por meio de quatro categorias de artigos: aqueles focados na afetividade, attude $e$ motvaça em matematica; 06 com foco no ensino de matematica e nas necessidades educacionais especias; aqueles com enfase na construçato do concelto de numero; e, por $7 \mathrm{~m}$, aqueles referentes a formaç̧o de protesscres e outros profissionais. Multos artigos atribuem as difouldades a motivaçalo Intrinseca para aprender matematica e a maioria ressata a importancla da iniclaç̧̧o a matenatica no inido da escolarizaçab. Essas publicap̧les evidenclam uma escassez signincativa de pesquisas metodologicas de Intervençbo com alunos que apresentam baxo desempenho escolar em matematca, cujos dados poderiam demonstrar a natureza desse desempenho e fundamentar

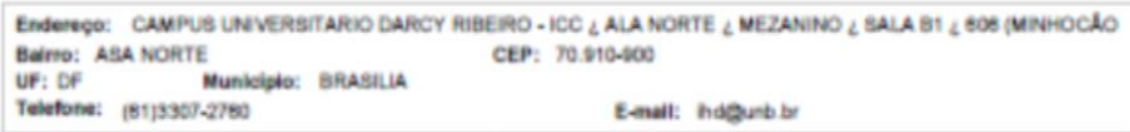




\section{INSTITUTO DE CIENCIAS HUMANAS / UNIVERSIDADE DE BRASILIA / CAMPUS}

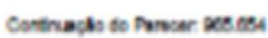

projetos de intervenç̧o mais ampios, com a participaç̧b de professores e outros protssionais que atuam nas series iniciais da escolarizaç50. Considerando esses aspectos, este projeto tem como cojetivo reailzar uma pesqusa metodologica de intervençbo psicologica com alunos do 50 ano do Ensino fundamental, de uma escola publica do Distito Federa, que sto considerados por suas professoras com baxo desempenho escolar em matematca, visando ao desenvolvmento de competencias concetuals nessa mesma dscipina. Participardo do estudo dols alunos, um do sexo feminino e cutro do sexo masculino, do quinto ano, com Idades entre 10 e 12 anc6. Sera adotada a perspectiva metodologica desenvolida por Favero (2009a, 2011, 2012). A coleta de dados acrangera tres fases distintas, todas desenvolvdas no ambiente escolx. A la fase sera real zada em auss etapas. Na 1 a etapa, sera desenvolvda uma entrevista indivdual, de acordo com os seguintes elxos norteadores: historia escois, concepples score a escola, nocles de tempo, noça espacia, relaples sodais, atvidades escolares favorias, concepples score escolaridade e competenda escoiar. A $2 a$ etapa da 1 a fase constara de uma avallaça psicopedagogica indlvidual, focada na relaçato entre as competenclas e difculdades em matematica, de modo a se obter dados sobre as competencias e difculdades relativas a0s componentes do sentido de numero e a compreensło do sistema de numeraça dedma. Serfo utllzadas sthapdes-problemas baseadas na Prova Brasl (Brasl, 2013), nos manuals para o ensino de matematica edilados pelo MEC e nas expeniencias ja descritas como, por exemplo, o trabaho de avalaçáb desenvolvido por Favero (2011). Com dase nos dacos cobtios nessa la fase, sera desenvoivida a 2a tase, que se constituira de sessdes psicopedagogicas com 05 dois participantes em interaçaso e nas quais a pesquisadora sera a medadora da resoluçalo das siluacoles matematcas propostas. A sequencla dessas sessoles e 0 seu planejamento em termos de atividades se fundamentardo na analise de cada sessto antenor. Do modo como proposto por Favero (2009), cada sessto fundamentara o planejamento da sessto segunte. Na 3 a e uttima fase, sera desenvoivida uma avallaça psicopedagogica individua focada na relaçabo entre as competencias e dinculdades em matematica, de modo a se obter dados sobre as competencias e difculdades relattvas acs componertes $\infty$ sentido de numero e a compreensto do sistema de numeraç̧o decimal. Serdo retomadas as sliuaçbes da aval aç5o psicopedagogica inicial, desenvoividas na 2 a etapa da 1 a fase. Todas as sessठes das tres fases do estudo serdo registradas em audio e video e transcritas na integra, de acordo com a proposta de Tain, Jimarkon e Iinghasill (2011). Sera assegurado a0s partipantes siglo dos dado6. Tambem serło analsados materiais escolares (cademos e provas). A proposta metodoiogica de Favero (2009a, 20090) articula quatro aspectos tecricos e conceltuals: a interacto entre 36 regulaçles cogritivas e as reguaçles sodiais; a mediaçb semictica; o efeto do sistema

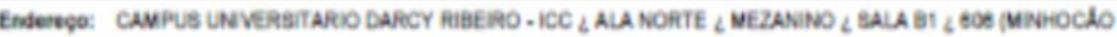
Barno: asa Nonte 


\section{INSTITUTO DE CIENCIAS \\ HUMANAS / UNIVERSIDADE DE BRASILIA / CAMPUS}

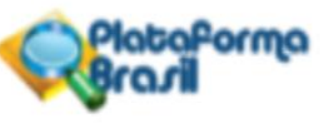

Conthachs te Navear secest

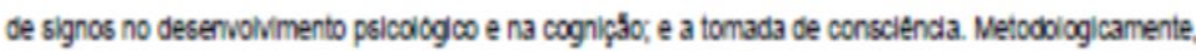
Isso implica em considerar tres aspectos psicoiogicos: a formaça de conceltos e seu sistema logico de representaçăo, a tomada de consclencla e a interaçalo social en que os conceltos salo formados, considerando-se o conhecimento comio resultado de um processo psilociogico (Favero, 20090). 06 dados obtidos evidenclardo os processos de desenvolvimento relacionacos a construçato da refenda logica e poderáo fundamentar futuros estudos com professores do ensino regular e das salas de recursos da Secretaria de Educaça do Distrito Federal.

\section{Objetivo da Pasquisa:}

O objetivo geral da pesquisa e desenvoiver, por melo de um procedimento psicopedagogico, as competendas matematccas conceftuas de alunos do $5^{\circ}$ ano do Ensino Fundamental, no que tange a Logica do Sistema de Numeraça Decimal e a sua notaçăo. Os objetivos secundarios sfo: levar os aunos a compreender o signilicado do numero e suas operaches, o valor relativo dos numeros, compor e decompor numeros; e perceber de que forma as quatro operaçbes aftetam no resultado das operaçes e julgar se o resultado de uma determinada operaç̧o e aceltavel ou nôs.

\section{Avallaça doe Fvacos $\theta$ Benenclos:}

Quanto a0s riscos, acredta-se que, pelo fato de 05 alunos serem submetidos a resoluçofo de stuaghesproblemas em dupla, possa haver timidez, ansiedade ou nervosismo durante as primeiras sessbes de avaliaça e intervençfo psicopedagoglica. Como beneficios, acreditase que, a0 tnal dos procedmentos, 05 envolidos poderáo ter desenvolvido competenclas matematicas que ainda estavam inciplentes ou mesmo que nło naviam sido desenvolvidas, alem do tato de eles se mostrarem mals cornantes quanto ao proprio desempenho.

\section{Comentarios $\theta$ Consideraç0es sobre a Pesqulsa:}

O projeto de pesquisa esta adequado as exigencias da Resoluçá CNS 456/2012 e complementares.

\section{Consideraç6es sobre 08 Termos de apresentaça obrigatorla:}

A pesquisadora fomeceu todos 05 termos de apresentaçăo obrigatoria. Ha justificativa para a nå apresentaça dos instrumentos de coleta de dados.

\section{Recomendaç68:}

Conclus098 ou Pandenclas a Llata de inadequaspees:

As pendencias foram sanadas pela pesquisadora. O projeto fol aprovado pelo CEPNIH.

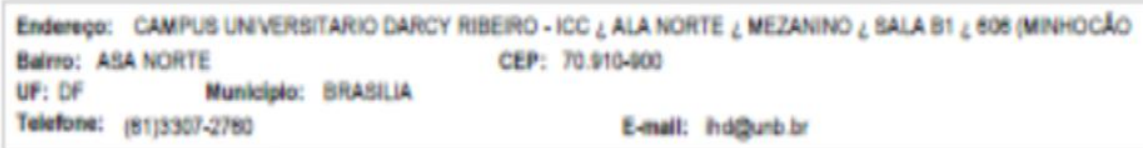




\section{INSTITUTO DE CIENCIAS HUMANAS / UNIVERSIDADE DE BRASILIA / CAMPUS}

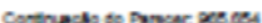

Situaç30 do Parecer:

Aprovado

Necessita Apreclaça da CONEP:

N50

Consideraçoes Finals a criterto do CEP:

BRASILIA, 26 de Fevereiro de 2015

Assinsodo por:

Livla Barbosa

(Coordenador)

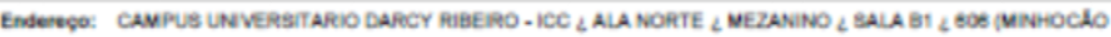
Earno: AsA Nopte.

Uf: DF Municigio: BRAsilia

CEP: ro.n10.400

Telefore: [81]9380-2780

Eemalt: hagub be 


\section{Anexo 2 - Autorização da Secretaria de Educação do Distrito Federal para realização}

\section{de pesquisa}

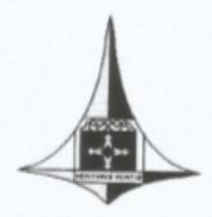

Memorando $N^{\circ} 83 / 2015$ - EAPE

SECRETARIA DE ESTADO DE EDUCAÇÃO

Escola de Aperfeiçoamento dos Profissionais da Educação

Brasília, 18 de março de 2015

PARA: CRE Taguatinga

ASSUNTO: autorização para realização de pesquisa

\section{Senhor Coordenador}

Autorizamos MARIA JULIANA DE FREITAS CARVALHO LOPES, aluna regular de mestrado do Programa de Pós-graduação em Desenvolvimento Humano e Saúde, do Instituto de Psicologia da Universidade de Brasília - UnB, a realizar pesquisa de campo nessa regional.

A pesquisa intitulada "A Pesquisa de Intervençâo Psicológica na Construçăo de Competências Matemáticas: um estudo com alunos do $5^{\circ}$ ano do Ensino Fundamental" tem como objetivo desenvolver, por meio de um procedimento psicopedagógico, as competências matemáticas conceituais de alunos do $5^{\circ}$ ano do Ensino Fundamental, no que tange à Lógica do Sistema de Numeração Decimal e à sua notação.

Informamos que o projeto de estudo foi analisado, e está em conformidade com as normas da SEDF.
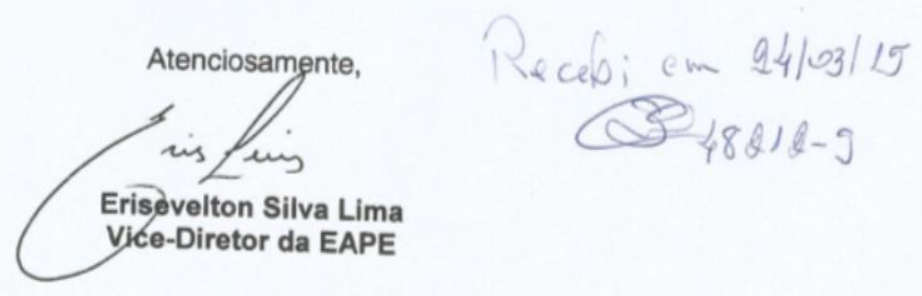
Anexo 3 - Termo de Consentimento Livre Esclarecido (TCLE)

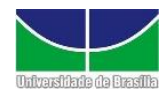 \\ INSTITUTO DE PSICOLOGIA - IP \\ PROGRAMA DE PÓS-GRADUAÇÃO EM PROCESSOS DE \\ DESENVOLVIMENTO HUMANO E SAÚDE - PGPDS \\ TERMO DE CONSENTIMENTO LIVRE E ESCLARECIDO
}

A criança

por quem o/a senhor(a) é responsável está sendo convidada a participar da pesquisa “A Pesquisa de Intervenção Psicológica na Construção de Competências Matemáticas: Um Estudo Com Alunos do $5^{\circ}$ Ano do Ensino Fundamental" de responsabilidade de Maria Juliana de Freitas Carvalho Lopes, aluna de mestrado, da Universidade de Brasília. O objetivo desta pesquisa é desenvolver uma pesquisa de intervenção que crie transformações do ponto de vista das competências dos alunos com dificuldades em Matemática, além de gerar análises e discussões sobre essas transformações de modo que possa gerar conhecimento sobre a aquisição escolar da Matemática.

Você receberá todos os esclarecimentos necessários antes, durante e após a finalização da pesquisa, e lhe asseguro que o nome da criança não será divulgado, sendo mantido o mais rigoroso sigilo mediante a omissão total de informações que permitam identificá-lo(a). Os dados provenientes da participação na pesquisa, tais como questionários, entrevistas, áudios de gravação, ficarão sob a guarda da pesquisadora responsável pela pesquisa.

A coleta de dados será realizada por meio de entrevistas, avaliações das competências matemáticas e sessões de intervenção psicopedagógicas. É para estes procedimentos que a criança está sendo convidada a participar. Sua participação na 
pesquisa não implica nenhum risco. Já como benefício espera-se que a criança desenvolva competências numéricas que fundamente seu conhecimento matemático atual e futuro.

A participação é voluntária e livre de qualquer remuneração ou benefício. Você é livre para recusar a participação da criança, retirar seu consentimento ou interromper sua participação a qualquer momento. A recusa em participar não irá acarretar qualquer penalidade ou perda de benefícios.

Se você tiver qualquer dúvida em relação à pesquisa, você pode me contatar através do telefone (61) 8417-9969 ou pelo e-mail mariju.fcl@gmail.com

A equipe de pesquisa garante que os resultados do estudo serão devolvidos aos participantes por meio de seminário para os professores da escola onde a criança estuda e disponibilização da dissertação, que será escrita com base nos dados da pesquisa, no site da biblioteca da Universidade de Brasília, podendo ser publicados posteriormente na comunidade científica em forma de artigo científico.

Este projeto foi revisado e aprovado pelo Comitê de Ética em Pesquisa do Instituto de Ciências Humanas da Universidade de Brasília - CEP/IH. As informações com relação à assinatura do TCLE ou os direitos do sujeito da pesquisa podem ser obtidos através do email do CEP/IH cep_ih@unb.br.

Este documento foi elaborado em duas vias, uma ficará com o(a) pesquisador(a) responsável pela pesquisa e a outra com o senhor(a).

Assinatura do (a) responsável pelo participante

Assinatura do (a) pesquisador (a)

Brasília, de de 


\title{
Anexo 4 - Termo de Utilização de Voz e de Imagem
}

\author{
TERMO DE AUTORIZAÇÃO PARA UTILIZAÇÃO DE IMAGEM E SOM DE \\ VOZ PARA FINS DE PESQUISA
}

$\mathrm{Eu}$, autorizo a utilização de imagem e som de voz de criança por quem sou responsável legal, na qualidade de participante/entrevistado(a) do projeto de pesquisa intitulado "A pesquisa de intervenção psicológica na construção de competências matemáticas: um estudo com alunos do $5^{\circ}$ ano do Ensino Fundamental" sob responsabilidade de Maria Juliana de Freitas Carvalho Lopes vinculada ao Programa de Pós Graduação em Desenvolvimento Humano e Saúde do Instituto de Psicologia da Universidade de Brasília.

A imagem e o som de voz podem ser utilizados apenas para análise por parte da equipe de pesquisa, apresentações em conferências profissionais e/ou acadêmicas, atividades educacionais.

Tenho ciência de que não haverá divulgação da imagem nem som de voz da criança por qualquer meio de comunicação, sejam elas televisão, rádio ou internet, exceto nas atividades vinculadas ao ensino e à pesquisa explicitados acima. Tenho ciência também de que a guarda e demais procedimentos de segurança com relação às imagens e sons de voz são de responsabilidade do(a) pesquisador(a) responsável.

Deste modo, declaro que autorizo, livre e espontaneamente, o uso para fins de pesquisa, nos termos acima descritos, da minha imagem e som de voz. 
Este documento foi elaborado em duas vias, uma ficará com o(a) pesquisador(a) responsável pela pesquisa e a outra com o(a) participante.

Assinatura do (a) participante Assinatura do (a) pesquisador (a)

Brasília, de de 


\title{
Anexo 5 - Termo de Assentimento
}

\author{
INSTITUTO DE PSICOLOGIA - IP \\ PROGRAMA DE PÓS-GRADUAÇÃO EM PROCESSOS DE \\ DESENVOLVIMENTO HUMANO E SAÚDE - PGPDS \\ TERMO DE ASSENTIMENTO PARA CRIANÇA E ADOLESCENTE
}

Olá, meu nome é Maria Juliana de Freitas Carvalho Lopes e estudo na Universidade de Brasília - UNB, onde faço o curso de mestrado em Psicologia. Estou convidando você para participar da pesquisa: "A Pesquisa de Intervenção Psicológica na Construção de Competências Matemáticas: Um estudo com alunos do $5^{\circ}$ ano do Ensino Fundamental", da qual sou responsável. Os seus pais permitiram que você participe.

Quero ajudá-lo(a) a desenvolver competências conceituais em Matemática, baseando-se na construção do conceito de número e sentido de número. Ou seja, vencer algumas de suas dificuldades na disciplina de Matemática. Participarão desta pesquisa duas crianças que tem entre dez e doze anos de idade e que estudam no $5^{\circ}$ ano do Ensino Fundamental na sua escola.

Você não precisa participar da pesquisa se não quiser, é um direito seu e não terá nenhum problema se desistir. A pesquisa será realizada na Escola Classe 50 de Taguatinga, onde você estuda. Você participará de atividades que envolvam Matemática. Durante essas atividades, utilizaremos materiais como sucatas, brinquedos, pequenos objetos, dinheirinho, para a resolução de situações-problemas que vamos realizar. Pode acontecer de você ficar tímido ou envergonhado no início das atividades, mas vou estar com você o tempo todo para apoiá-lo. Depois você irá começar a ter mais facilidade nas atividades e assim vai se sentir mais seguro e feliz.

Quando terminarmos a pesquisa, farei um trabalho na universidade, contando o que nós fizemos em sua escola desde o início. Mas pode ficar tranquilo que o seu nome e o do 
colega que participará com você não será divulgado. As pessoas não conseguirão identificar quem participou.

Se você tiver qualquer dúvida em relação à pesquisa, você pode me perguntar pelo telefone (61) 8417-9969 ou pelo e-mail mariju.fcl@gmail.com.

Este projeto foi revisado e aprovado pelo Comitê de Ética em Pesquisa do Instituto de Ciências Humanas da Universidade de Brasília - CEP/IH. As informações com relação à assinatura do TERMO DE ASSENTIMENTO ou os direitos do sujeito da pesquisa podem ser obtidos através do e-mail do CEP/. IH cep_ih@unb.br

Este documento foi elaborado em duas vias, uma ficará com o(a) pesquisador(a) responsável pela pesquisa e a outra com você.

\section{CONSENTIMENTO PÓS-INFORMADO}

$\mathrm{Eu}$

aceito

participar da pesquisa "A Pesquisa de Intervenção Psicológica na Construção de Competências Matemáticas: Um estudo com alunos do $5^{\circ}$ ano do Ensino Fundamental”. Entendi as coisas ruins e as coisas boas que podem acontecer. Entendi que posso dizer "sim" e participar, mas que, a qualquer momento, posso dizer "não" e desistir e que ninguém vai ficar chateado. A pesquisadora tirou minhas dúvidas e conversou com os meus responsáveis. Recebi uma cópia deste termo de assentimento, li e concordo em participar da pesquisa.

BRASÍLIA, de de 


\section{Anexo 6 - Termo de responsabilidade pelo uso de informações de documentos para fins de pesquisa}

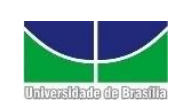

INSTITUTO DE PSICOLOGIA - IP

PROGRAMA DE PÓS-GRADUAÇÃO EM PROCESSOS DE DESENVOLVIMENTO HUMANO E SAÚDE - PGPDS

\section{TERMO DE RESPONSABILIDADE PELO USO DE INFORMAÇÕES E CÓPIAS DE DOCUMENTOS PARA FINS DE PESQUISA}

Maria Juliana de Freitas Carvalho Lopes portadora do documento de identificação de $n^{\circ}$ e do CPF $n^{\circ}$ domiciliada à(ao)/na

DECLARA estar ciente:

a) De que os documentos aos quais solicitou acesso e/ou cópias são custodiados pela Escola Classe 50 de Taguatinga.

b) Da obrigatoriedade de, por ocasião da divulgação, se autorizada, das referidas reproduções, mencionar sempre que os respectivos documentos em suas versões originais pertencem ao acervo da Escola Classe 50 de Taguatinga.

c) De que as cópias dos documentos objetos deste termo não podem ser repassadas a terceiros;

d) Das restrições a que se referem os art. 4 e 6 da Lei n 8.159 de 08.01.1991 (Lei de Arquivos); da Lei no 9610, de 19.02.1998 (Lei de Direitos Autorais); dos art. 138 e 145 do Código Penal, que prevê os crimes de calúnia, injúria e difamação; bem como da proibição, decorrente do art. $5^{\circ}$, inciso X, da Constituição da República Federativa do 
Brasil, de 1988, de difundir as informações obtidas que, embora associadas a interesses particulares, digam respeito à honra e à imagem de terceiros;

e) De que a pessoa física ou jurídica, responsável pela utilização dos documentos, terá inteira e exclusiva responsabilidade, no âmbito civil e penal, a qualquer tempo, sobre danos materiais ou morais que possam advir da divulgação das informações contidas nos documentos bem como do uso das cópias fornecidas, eximindo, consequentemente, de qualquer responsabilidade, Escola Classe 50 de Taguatinga.

DECLARA igualmente que as informações e as cópias fornecidas serão utilizadas exclusivamente por Maria Juliana de Freitas Carvalho Lopes e sua orientadora de Mestrado Prof. ${ }^{a}$ Dr. ${ }^{a}$ Maria Helena Fávero para fins de pesquisa no âmbito do projeto $A$ pesquisa de intervenção psicológica na construção de competências matemáticas: um estudo com alunos do $5^{\circ}$ ano do Ensino Fundamental vinculado ao Programa de PósGraduação em Processos de Desenvolvimento Humano e Saúde do Instituto de Psicologia da Universidade de Brasília.

Brasília, 11 de novembro de 2014.

Este documento foi elaborado em duas vias, uma ficará com o(a) pesquisador(a) responsável pela pesquisa e a outra com o senhor(a).

Assinatura do (a) responsável pelo participante

Assinatura do (a) pesquisador (a) 